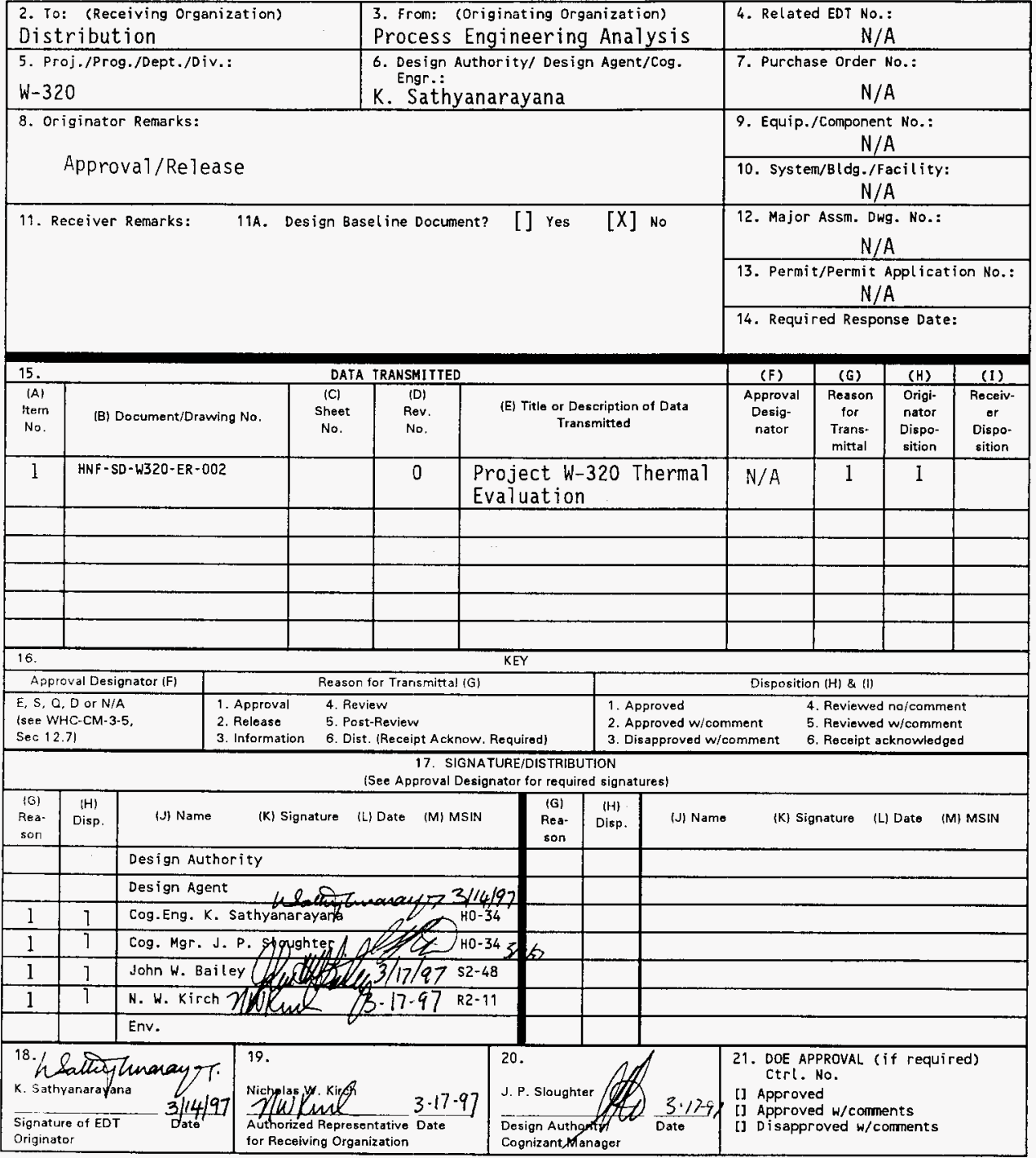



HNF-SD-W320-ER-002, Rev, 0

\title{
W-320 Project Thermal Modeling
}

\author{
K. Sathyanarayana
}

Numatec Hanford Inc., Richland, WA 99352

U.S. Department of Energy Contract DE-AC06-96RL13200

$\begin{array}{llll}\text { EDT/ECN: } & 614693 & \text { UC: } 2020 & \\ \text { Org Code: } & 74350 & \text { Charge Code: } & \text { D2MTR } \\ \text { B\&R Code: } & \text { EW3135040 } & \text { Total Pages: } & 787\end{array}$

Key Words: Project W-320, Tank 241-C-106, Tank 241-AY-102, HUB, GOTH Computer Code and Process control.

Abstract: This report summarizes the results of thermal analysis performed to provide a technical basis in support of Project $W-320$ to retrieve by sluicing the sludge in Tank 241-C-106 and to transfer into Tank 241-AY-102. Prior theraml evaluations in support of Project H-320 safety analys is assumed the availability of 2000 to $3000 \mathrm{CFM}$, as provided by Tank Farm Operations, for tank floor cooling channels from the secondary ventilation system. As this flow availability has no technical basis, a detailed Tank 241-AY-102 secondary ventilation and floor cooling channel flow model was developed and analysis was performed. The results of the analysis show that only about 150 $\mathrm{cfm} \mathrm{flow}$ is in floor cooling channels. Tank 241-AY-102 thermal evaluation was performed to determine the necessary cooling flow for floor cooling channels using W-030 primary ventilation systern for different quantities of Tank 241-C-106 sludge transfer into Tank 241-AY-102. These sludge transfers meet different options for the project along with minimum required modifications of the ventilation systems. Also the results of analys is for the amount of sludge transfer using the current system is presented.The effect of sludge fluffing factor, heat generation rate and its distribution between supernatant and sludge in Tank 241-AY-102 on the amount of sludge transfer from Tank 241-C-106 were evaluated and the results are discussed. Also transient thermal analys is was performed to estimate the time to reach the steady state. For a 2 feet sludge transfer, about 3 months time will be required to reach steady state. Therefore, for the purpose of process control, a detailed transient thermal analysis using GOTH Computer Code will be required to determine transient response of the sludge in Tank 241-AY-102. Process control considerations are also discussed to eliminate the potential for a steam bump during retrieval and storage in Tanks 241-C-106 and 241-AY-102 respectively.

GOTH is a trademark of JMI, which is derived from GOTHIC - a registered trademark of the EPRI Corp.

TRADEMARK DISCLAIMER. Reference herein to any specific comercial product, process, or service by trade name, trademark, manufacturer, or otherwise, does not necessarily constitute or imply its endorsement, recomendation, or favoring by the United States Goverment or any agency thereof or its contractors or subcontractors.

Printed in the United States of America. To obtain copies of this document, contact: Document Control Services, P.O. Box 950. Mailstop H6-08, Richland WA 99352, Phone (509) 372-2420; Fax (509) 376-4989.
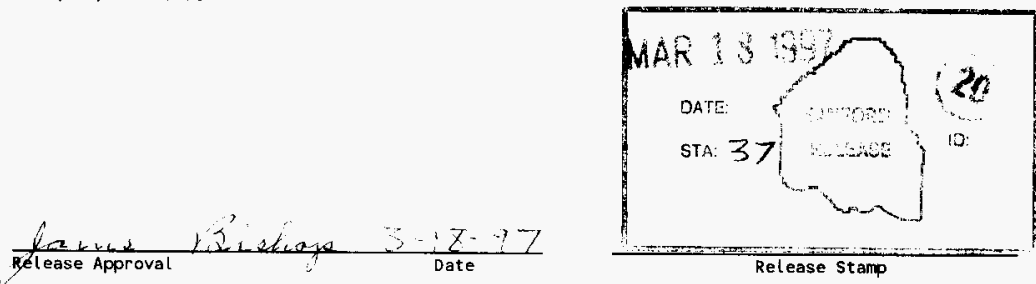

\section{Approved for Public Release}



HNF-SD-W320-ER-002, Rev. 0

Project W-320 Thermal Evaluation

K. Sathyanarayana

D. M. Ogden

Numatec Hanford Corporation

Richland, Washington

B. C. Fryer

M. J. Thurgood

JMInc.

Richland, Washington

Issued by

NUMATEC HANFORD CORPORATION

for the

U. S. DEPARTMENT OF ENERGY

RICHLAND OPERATIONS OFFICE

RICHLAND, WASHINGTON 
HNF-SD-W320-ER-002, Rev, 0

(This page intentionally left blank.) 
HNF-SD-W320-ER-002, Rev. 0

\section{CONTENTS}

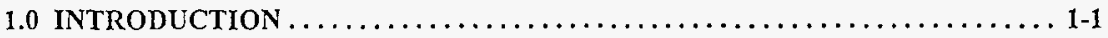

2.0 TANK 241-AY-102 ANNULUS SYSTEM EVALUATION $\ldots \ldots \ldots \ldots \ldots \ldots \ldots .2$

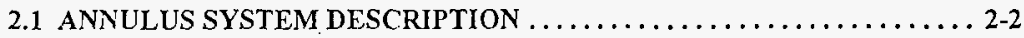

2.2 GOTH SECONDARY VENTILATION SYSTEM NETWORK MODEL . . 2-5

2.2.1 Inlet Manifold Piping Runs and Drop Lines . . . . . . . . . 2-8

2.2.2 Piping and Floor Channel Wall Fraction ............. 2-10

2.2.3 Fittings, Other Form Losses, and Filter............. 2-10

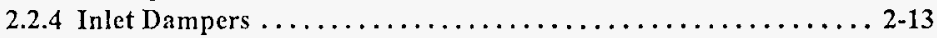

2.3 GOTH NETWORK MODEL VALIDATION . . . . . . . . . . . 2-13

2.3.1 Tanks 241-AY-101 and 241-AY-102 Secondary Ventilation Data . 2-13

2.3.2 Network Model Comparisons to Tank Data ............ 2-16

2.4 ANNULUS/FLOOR VENTILATION SYSTEM PERFORMANCE $\ldots \ldots$ 2-16

2.4.1 Current System with Annulus Vacuum Restrictions, 6-Inch Drop Lines

Unblocked and Blocked ................... 2-16

2.4.2 Blower--Unblocked and Blocked 6-Inch Drop Lincs . . . . . . . 2-22

2.4.3 Blockage of all 6-Inch Annulus Inlet Drop Lines Plus Removal of

3-Inch Pipe Restrictions in 4-Inch Floor Inlet Drop Lines . . 2-22

2.4.4 Blockage of Three 6-Inch Drop Lines .............. 2-25

2.4.5 Summary Table of Cases .................... 2-25

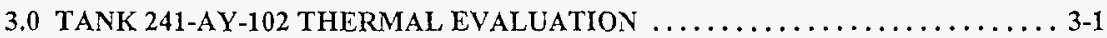

3.1 HUB MODEL DESCRIPTION $\ldots \ldots \ldots \ldots \ldots \ldots \ldots \ldots \ldots \ldots \ldots \ldots \ldots .1$

3.2 GOTH FLOOR CHANNEL MODEL DESCRIPTION AND RESULTS $\ldots$ 3-3

3.3 HUB MODEL INPUT PARAMETERS $\ldots \ldots \ldots \ldots \ldots \ldots \ldots \ldots \ldots \ldots \ldots$

3.3.1 Tank 241-C-106 Heat Load Distribution . . . . . . . . . . 3-10

3.3.2 Tank 241-AY-102 Fluffing Factor .............. 3-10

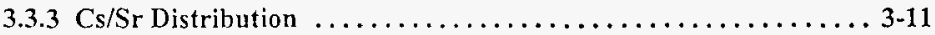

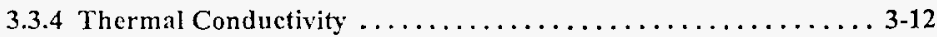

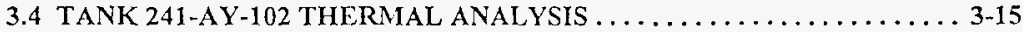

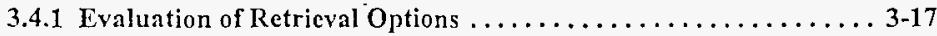

3.4.2 Sludge Fluffing Factor Parametric Analyses . . . . . . . . 3-26

3.4.3 ${ }^{137} \mathrm{Cs} /{ }^{00} \mathrm{Sr}$ Distribution Parmetric Analyses . . . . . . . . . . . . 3-29

3.5 EVALUATION OF PHASE 1 SLUICING OF TANK 241-C-106 . . . . 3-29

3.5 .1 Margin of Safety . . . . . . . . . . . . . . . . . . 3-29

3.5.2 Heat Generation Rate Parmetric Analyses ............. 3-33

3.5.3 Effect of Reduced Primary Ventilation Flow ............ 3-33 
3.6 WASTE RETRIEVAL POTENTIAL UNDER OPTIMISTIC CONDITIONS

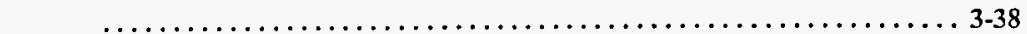

3.7 TRANSIENT THERMAL EVALUATION $\ldots \ldots \ldots \ldots \ldots \ldots \ldots \ldots \ldots, 3-42$

4.0 PROCESS CONTROL CONSIDERATIONS $\ldots \ldots \ldots \ldots \ldots \ldots \ldots \ldots \ldots \ldots, 4$. 1

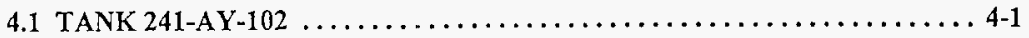

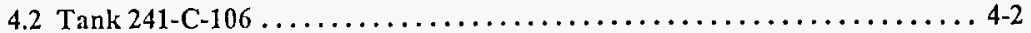

4.2.1 GOTH Process Control Model Description ............. 4-2

4.2.2 Tank 241-C-106 Temperature Control ................ 4-3

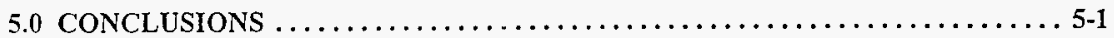

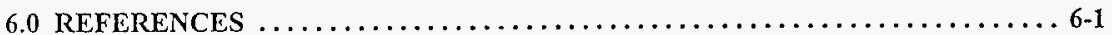

\section{TABLES}

2-1. Complete Turbulence Friction Factor--Commercial Steel Pipe $\ldots \ldots \ldots \ldots \ldots \ldots$ 2-11

2-2. 1996 241-AY-102 Annulus Exhauster Startup Data-6-Inch Drop

Lines Unblocked (Jennings 1996b) ......................... 2-14

2-3. Tank 241-AY-102 1987 Data--6-Inch Drop Lines Unblocked

(Powell 1989) ........................................ 2-15

2-4. Tank 241-AY-101 1988 Data--6-Inch Drop Lines

Unblocked (Nordquist 1988a) ............................. 2-15

2-5. Tank 241-AY-101 1988 Data--6-Inch Drop Lines

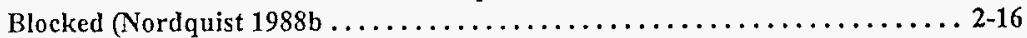

2-6. Annulus Vacuum, Blower Discharge Pressure, Flow Rate at Floor

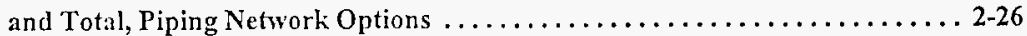

3-1. Tank 241-AY-102 and Tank 241-C-106 Waste Parameters .............. 3-9

3-2. Tank 241-C-106 Waste Heat Load Distribution ................... 3-10

3-3. Tank 241-AY-102 Nonconvective Waste Fluff Factor.

(Brooks, et al. 1997 / Lumetta 1996) ......................... 3-11

3-4. Tank 241-A Y-102 Nonconvective Waste Fluffing Factor.

(Babad 1996) ........................................... 311

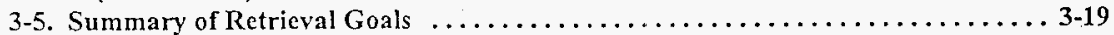

4-1. Process Control Considerations for Tank 241-AY-102 $\ldots \ldots \ldots \ldots \ldots \ldots \ldots$ 4-2

\section{FIGURES}

2-1. Side View of Tank 241-AY-102 Prinary and Secondary Ventilation after Transfer of $4.75 \mathrm{ft}$ of $241-\mathrm{C}-106$ Sludge, Fluffed a Factor of $2 \ldots \ldots \ldots 2-3$

2-2. Tank 241-AY-102 Secondary Ventilation Floor Piping, Insulating Concrete Channels and Thermocouple Locations, and Expected Maximum Floor Sludge Temperature Locations . . . . . . . . . . . . 
2-3. Tank Stecl and Insulating Concrete Floor and

Floor Ventilation Channel Dimensions--Tank 241-AY-102 ........... 2-6

2-4. Secondary Ventilation Inlet Manifold, 6-Inch Drop Lines to Top

of Annulus, and 4-Inch Drop Lines to Floor Ventilation Channels $\ldots \ldots \ldots \ldots .2-7$

2-5. GOTH Series/Parallel Piping and Concrete Duct Secondary

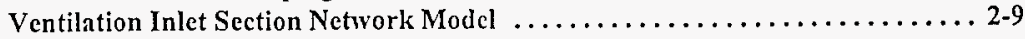

2-6. Secondary Ventilation Roughing Filter

and Pre-Filter Hydraulic Characteristics $\ldots \ldots \ldots \ldots \ldots \ldots \ldots \ldots \ldots \ldots \ldots \ldots \ldots \ldots, 12$

2-7. Volumetric Flow vs. Annulus Vacuum with Atmospheric Inlet

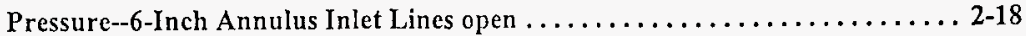

2-8. Volumetric Flow vs. Annulus Vacuum with

Atmospheric Inlet Pressure - 6 Inch Annulus Inlet Lines Blocked .......... 2-19

2-9. Floor Volumetric Flow vs. Annulus Vacuum with Atmospheric Inlet

Pressure--6-Inch Annulus Inlet Lines Blocked and Unblocked ......... 2-20

2-10. Volumetric Flow vs. Annulus Vacuum with Atmospheric

Inlet Pressure ...................................... 21

2-11. Floor Volumetric Flow vs. Annulus Vacuum or System Pressure

Drop--6-Inch Annulus Inlet Lines Blocked and Unblocked $\ldots \ldots \ldots \ldots \ldots \ldots 2-23$

2-12. Volumetric Flow vs. Annulus Vacuum with

Atmospheric Inlet Pressure ............................... 24

2-13. Volumetric Flow ys. Annulus Vacuum with

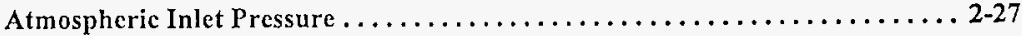

3-1. 2-D Nodalization for Middle Sludge and Floor Region--Approximate

Maximum Distance Between Channels 4.5 feet $\ldots \ldots \ldots \ldots \ldots \ldots \ldots \ldots \ldots . .4 .4$

3-2. Tank 241-AY-102 Sludge Temperature Distribution for

Models Three Radial Regions--155 cfm Floor Channel Flow,

$2.5 \mathrm{ft} 241-\mathrm{C}-106$ Sludge Transfer ................................

3-3. Tank 241-AY-102 Gas Temperatures at Floor Channel Exits

Corresponding to Models 3 Radial Regions-- $155 \mathrm{cfm}$ Floor Channel

Flow, $2.5 \mathrm{ft}$ Tank $241-\mathrm{C}-106$ Sludge Transfer $\ldots \ldots \ldots \ldots \ldots \ldots \ldots \ldots \ldots \ldots \ldots \ldots \ldots \ldots \ldots .6$

3-4. Tank 241-AY-102 Contents Temperatures for $155 \mathrm{~cm}$

Floor Channel and $2.5 \mathrm{ft}$ Tank 241-C-106 Sludge Transfer ............. 3-7

3-5. Effective Sludge Thermal Conductivity Variation With Solids Concentration ... 3-14

3-6. Tank 241-AY-102 Aging Waste Double-Shell Tank................. 3-16

3-7. Temperature Distribution of the Combined Sludge in Tank 241-AY-102 using

W-030 Primary Ventilation System with 0 and 150 CFM Floor Cooling Channel

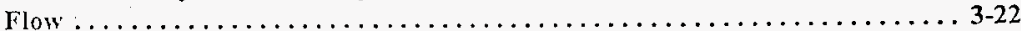

3-8. Temperature Distribution of the Combined Sludge in Tank 241-AY-102 using W-030

Primary Ventilation System with a) $1000 \mathrm{CFM}$ at $70 \mathrm{~F}$ b) $750 \mathrm{CFM}$ at $40 \mathrm{~F}$ and 850

CFM at $70 \mathrm{~F}$ floor cooling Channel Flow . ......................

3-9. Temperature Distribution of the Combined Sludge in Tank 241-AY-102 using W-030

Primary Ventilation System with a) $2000 \mathrm{CFM}$ at $70 \mathrm{~F}$ b) $1400 \mathrm{CFM}$ at $40 \mathrm{~F}$ and

1200 CFM at $40 \mathrm{~F}$ Floor Cooling Channel Flow . . . . . . . . . . . . . . 
3-10. Temperature Distribution of the Combined Sludge in Tank 241-AY-102 using W030 Primary Ventilation System with a) 3000 CFM at $70 \mathrm{~F}$ and b) 2200 CFM at $40 \mathrm{~F}$

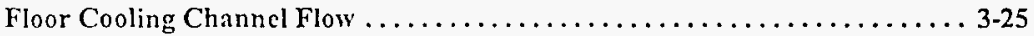

3-11. Temperature Distribution of the Conbined Sludge in Tank 241-AY-102 using W030 Primary Ventilation System with a) $3000 \mathrm{CFM}$ and b) $2500 \mathrm{CFM}$ at $40 \mathrm{~F}$ Floor Cooling Channcl Flow .......................... 3-27

3-12. Temperature Distribution of the Combined Sludge in Tank 241-AY-102 using W030 Primary Ventilation System with a) 1800 CFM for Fluff Factor of 3, b) 1000 CFM for Fluff Factor of $1000 \mathrm{CFM}$ and b) $200 \mathrm{CFM}$ for Fluff Factor of 1 at $70 \mathrm{~F}$

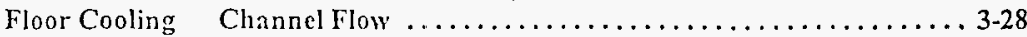

3-13. Temperature Distribution of the Combined Sludge in Tank 241-AY-102 using W030 Primary Ventilation System with 150 CFM at 70 F Floor Cooling Channel Flow and a) $10 \%$ and b) $50 \%$ heat in Supernatant and the remaining in Sludge . . . 3-30

3-14. Temperature Distribution of the Combined Sludge in Tanli $241-\mathrm{AX}-102$ using W030 Primary Ventilation System with 150 CFM at $70 \mathrm{~F}$ Floor Cooling Channel Flow for Different Quantitics of SIudge with Fluff Factor of 2. Heat Generation Rates

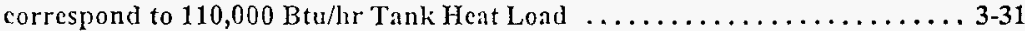

3-15. Temperature Distribution of the Combined Sludge in Tank 241-AY-102 using W030 Primary Ventilation System with $150 \mathrm{CFM}$ at $70 \mathrm{~F}$ Floor Cooling Channel Flow for Different Quantitics of Sludge with Fluff Factor of 1. Heat Generation Rates correspond to $110,000 \mathrm{Btu} / \mathrm{hr}$ Tank Heat Load . . . . . . . . . . . 3-32

3-16. Temperature Distribution of the Combined Sludge in Tank 241-AY-102 using W030 Primary Ventilation System with $150 \mathrm{CFM}$ at $70 \mathrm{~F}$ Floor Cooling Channel Flow for Different Quantities of Sludge with Fluff Factor of 2. Heat Gencration Rates correspond to $132,400 \mathrm{Btu} / \mathrm{hr}$ Tank Heat Load . . . . . . . . . . . . 3-35

3-17. Tempcrature Distribution of the Combined Sludge in Tank 241-AY-102 using W030 and 702-A Primary Ventilation System with 0 and 150 CFM at 70 F Floor Cooling Channel Flow for 88,000 gallons(32 in.) of Sludge with a Heat Load of $40,100 \mathrm{Btu} / \mathrm{hr}$ and Fluff Factor of 2 . Heat Generation Rate corresponds to 132,400

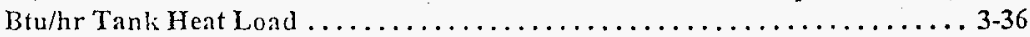

3-18. Temperature Distribution of the Combined Sludge in Tank 241-AY-102 using 100 CFM of W-030 Primary Ventilation System Flow and 150 CFM Floor Cooling Channel Flow for Different Quantitics of Sludge with Fluff Factor of 2. Heat Gencration Rates correspond to 132,400 Btu/hr Tank Heat Load . . . . . . 3-37

3-19. Temperature Distribution of the Combined Sludge in Tank 241-AY-102 using W030 Primary Ventilation System with 150 CFM at $70 \mathrm{~F}$ Floor Cooling Channel Flow for 197,000 gallons of Sludge having a Heat Load of $110,000 \mathrm{Btu} / \mathrm{hr}$ and with Fluff

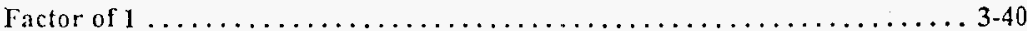

3-20. Temperature Distribution of the Combined Sludge in Tank 241-AX-102 using W030 Primary Ventilation System with 150 CFM at 70 F Floor Cooling Channel Flow for 197,000 gallons of Sludge having a Heat Load of $110,000 \mathrm{Btu} / \mathrm{hr}$ and with Fluff

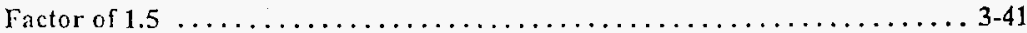

3-21. Transient Temperatures Response for Tank 241-AY-102 . . . . . . . . 3-44

3-22. Thermal Time Constant for $241-A Y-102 \ldots \ldots \ldots \ldots \ldots \ldots \ldots \ldots \ldots \ldots \ldots$

3-23. Transient Temperature Fluffing Factor Parametric Analyses . . . . . . . . 3-46 
4-1. Tank 241-C-106 Cross-Section, Contents, and Major Dimensions ........... 4-5

4-2. Tank 241-C-106 GOTH Sludge Temperature Process Control Model--Dimensions and

Computation Node Size . . . . . . . . . . . . . . . . . . . . . . 4-6

4-3. Tank 241-C-106 GOTH Sludge Temperature Process Control Model--Boundary

Conditions and Time Controlled Conductors $\ldots \ldots \ldots \ldots \ldots \ldots \ldots \ldots \ldots \ldots 4-7$

4-4. Waste Temperature, Level, and

Saturation Temperatures vs Time--Short (12 hr) Temperature Control Hold Period

$\ldots \ldots \ldots \ldots \ldots \ldots \ldots \ldots \ldots \ldots \ldots \ldots \ldots \ldots \ldots \ldots \ldots \ldots \ldots \ldots \ldots \ldots$

4-5. Waste Temperature, Level, and

Saturation Temperatures vs Time--Short (12 hr) Temperature Control Hold Period-

-Expanded Time Scale During Sluicing Operations ................ 4-9

4-6. Waste Temperature, Level, and

Saturation Temperatures vs Time--Long (21 day) Temperature Control Hold Period

4-7. Waste Temperature, Level, and

Saturation Temperatures vs Time-- 5 day Temperature Control Hold Period .. 4-12

4-8. Waste Temperature, Level, and Saturation Temperatures vs

Time During Sluicing Operation-- 5 Day Temperature Control Hold Period.

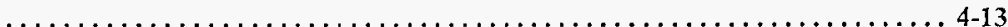

4-9. IVaste Temperature, Level, and Saturation Temperature vs

Time During Sluicing Operation- 5 Day Temperature Control Hold Period . . 4-14

\section{APPENDIXES}

APPENDIX A Internal Memo, E. M. Nordquist to R. J. Murkowski . ........... A-i APPENDIX B Meeting Minutes, Project B-673 Air Flow, August 30, 1988. . ....... B-i APPENDIX C MC Daily Log from Mark M. Jennings, October 17, 1996. . . . . . . C-i APPENDIX D Evaluation of AY-102 Slurry Distribution Flow Field . . . . . . . . D-i APPENDIX E Tank 241-AY-102 Annulus and Floor Cooling Channel Flows ........ E-i

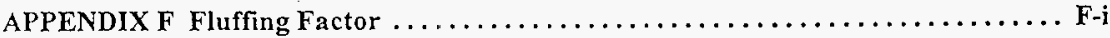
APPENDIX $G$ Fluff Factor including the effect of dissolution of solids . ......... G-i APPENDIX H Cs137 Heat Load of Tank 241-C-106.................. H-i APPENDIX I JMI-WT002 Report, Revised Tank Heat Load For Tank C-106 ........ I-i 
HNF-SD-W320-ER-002, Rev. 0

(This page intentionally left blank.) 


\subsection{INTRODUCTION}

The goal of Project W-320 is to retrieve, through sluicing, the soft sludge from Tank 241C-106. The receiver tank for the sluicing operation is Tank 241-AY-102. Tank 241-C-106 is a single shell tank (SST) containing 197,000 gallons ( $\sim 69$ inches) of soft sludge with a tank heat load estimate of 110,000 Btu/h (Bander 1993) to 132,400 Btu/h (Fryer 1995) for June 1994. Tank 241-AY-102 is a double shell tank (DST) operating with a sludge layer of 32,000 gallons ( $12 \mathrm{in}$.) and supernate of 812,000 gallons ( $\sim 25 \mathrm{ft}$.). The estimated heat load of Tank 241-AY102 for February 1995 was 33,000 Btu/h (Sathyanarayana 1996b). The heat load addition to Tank 241-AY-102 combined with the increased solids depth, could cause the sludge temperature to increase and can potentially exceed the operating temperature limit. The increase in sludge temperature depends on the amount of Tank 241-C-106 sludge transfer, the sludge properties, and the operating conditions of both the dome and annulus/floor ventilation systems. The peak sludge temperature limit (WHC-SD-WM-BIO-001, Rev E) is $30^{\circ} \mathrm{F}$ below local saturation temperature $(-220 \mathrm{~F}$ in the sludge $)$. This limit is established to ensure the elimination of the potential for a spontaneous steam release (steam bump) which has been observed in single shell aging waste tanks (Bendixsen, 1990) and evaluated by computer modeling (Sathyanarayana 1996a).

The 1994 Tank 241-C-106 process test demonstrated that the maximum sludge temperature is near local saturation temperature during normal late summer operation, cooling to a few degrees below saturation during late winter. Off normal events such as the 1994 process test had resulted in a large two phase saturation region in the sludge (Thurgood 1995). High yield strength of the settled sludge of this tank makes a spontaneous steam bump unlikely. However, intrusive waste activities could result in a steam bump. As a result, the Project W-320 safety documentation (Conner, 1996) requires the sludge to remain subcool throughout the waste retrieval operations.

This report presents the results of thermal evaluation performed for Project W-320. The study includes the thermal evaluations of Tank 241-AY-102 for the increased sludge and thermal loading and of Tank 241-C-106 for loss of hydrostatic head during the sluicing operations. A large quantity of Tank 241-C-106 sludge transfer requires the use of secondary ventilation flow for active sludge cooling particularly near the tank floor. Strategies for temperature process control in both Tank 241-AY-102 and Tank 241-C-106 were developed. Section 2 of this report presents the description of the GOTH model for Tank 241-AY-102 annulus/floor ventilation system evaluation. The thermal evaluation results of Tank $241-\mathrm{AY}-102$ for different options of Tank 24I-C-106 sludge transfer and in particular the amount of sludge transfer potential with the current secondary ventilation system is presented in Section 3. Also, included are the results for complete sludge transfer from Tank 241-C-106 using optimistic assumptions with regard to heat load, fluff factor and cooling effectiveness. In Section 4, temperature process control based upon the thermal evaluations is given. 
The appendixes of this report primarily document supporting information. Appendix A provides the annulus ventilation test results of Tank AY-101 with 6 inch drop lines unblocked condition.. Appendix B describes Tank AY-101 annulus ventilation flow test results for 6 inch drop lines blocked condition. Appendix C provides the details of Tank AY-102 annulus ventilation system flow measurements. In addition, Appendix D provides an evaluation of the Tank 241-AY-102 supernate flow field distribution during the operation of the slurry flow distributor. The results of this analysis supports the resolution of flammable gas issues. Appendix E provides the initial data provided for Tank AY-102 floor cooling channel flows for use in thermal analysis of Tank AY-102. Appendix $F$ provides the fluff factor information for Tank $\mathrm{C}-106$ sludge. The fluff factor and effect of dissolution of Tank C-106 solids is described in Appendix G. The information on Cs-137 heat load of Tank C-106 waste is given in Appendix H. Appendix I provides the report on the revised estimate of Tank $\mathrm{C}-106$ heat load based on GOTH analysis of the process test of June, 1994. 
HNF-SD-W320-ER-002, Rev. 0

\subsection{TANK 241-AY-102 ANNULUS SYSTEM EVALUATION}

The quantity of Tank 241-C-106 sludge that can be safely transferred to Tank 241-AY-102 depends on five primary factors:

- The resultant thickness of Tank 241-AY-102 sludge after transfer

- The heat generation rate and axial distribution

- Sludge conductivity

- The effectiveness of the primary or dome ventilation

- The effectiveness of the secondary or annulus/floor ventilation.

Prior analysis (Sathyanarayana 1996b) assumed that the current secondary ventilation system was capable of delivering 2000 to $3000 \mathrm{cfm}$ flow to the tank floor cooling channels (Tardiff $1995 \mathrm{a}, 1995 \mathrm{~b}$ ). It was later learned that the system was not capable of providing the assumed flow to the floor cooling channels. A detailed evaluation of the current air flow capability of the inlet portion of the secondary annulus/floor ventilation system was made to establish the actual flow characteristics of the system. The system description and details of the evaluation results are provided in this section.

In its current configuration, subject to current operations limits on the annulus vacuum for Project W-030 operating conditions, the floor flow is limited to about $155 \mathrm{cfm}$. Increases in floor flow possibly up to $2000 \mathrm{cfm}$ can be achieved, but will require system and operations limit modifications. The system modifications considered included the addition of an inlet blower, the blockage of the 6-inch annulus drop lines (which eliminates floor channel bypass), removal of 3 -inch restricter lines in the 4-inch drop lines leading to the floor channels, and chilling of the primary and secondary system inlet air. System operation changes considered includ the operation of floor/annulus system at high annulus vacuum and operation of the floor/annulus system inlet piping at positive pressure. To achieve significant increases in floor channel air flow, both system modifications and system operations changes would be required.

\subsection{ANNULUS SYSTEM DESCRIPTION}

A side view of the secondary ventilation system piping and floor channels is illustrated in Figure 2-1 together with waste contents following a hypothetical $4.75 \mathrm{ft}$ waste transfer from Tank 241-C-106 and a transferred sludge fluffing factor of 2. The network of concrete air flow channels in the floor of the tank is illustrated in Figure 2-2 together with the four 4-inch horizontal pipes which deliver air from the drop lines to the distribution plenum at the floor center. Floor thermocouple locations and maximum temperature locations expected when the secondary ventilation system is operational are also shown in Figure 2-2. 
Figure 2-1. Side View of Tank 241-AY-102 Primary and Secondary Ventilation after Transfer of $4.75 \mathrm{ft}$ of 241-C-106 Sludge, Fluffed a Factor of 2.

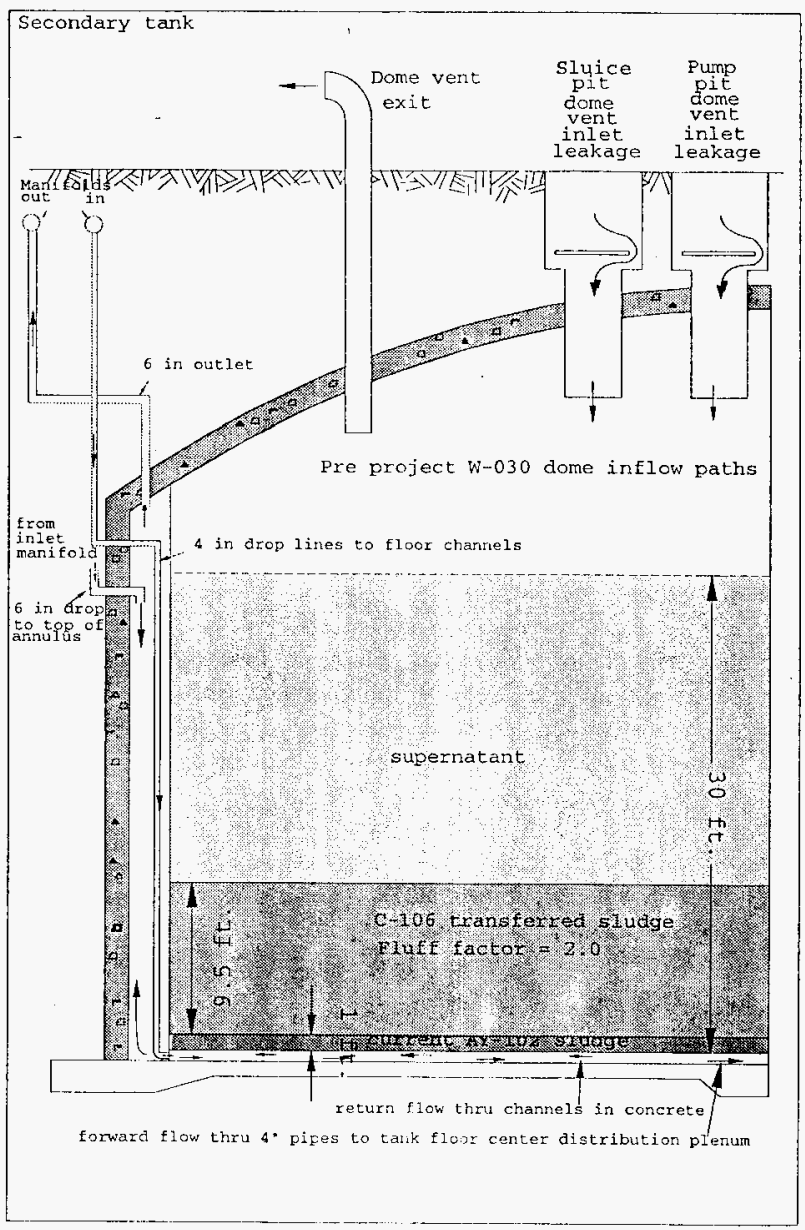


Figure 2-2. Tank 241-AY-102 Secondary Ventilation Floor Piping, Insulating Concrete Channels and Thermocouple Locations, and Expected Maximum Floor Sludge Temperature Locations.

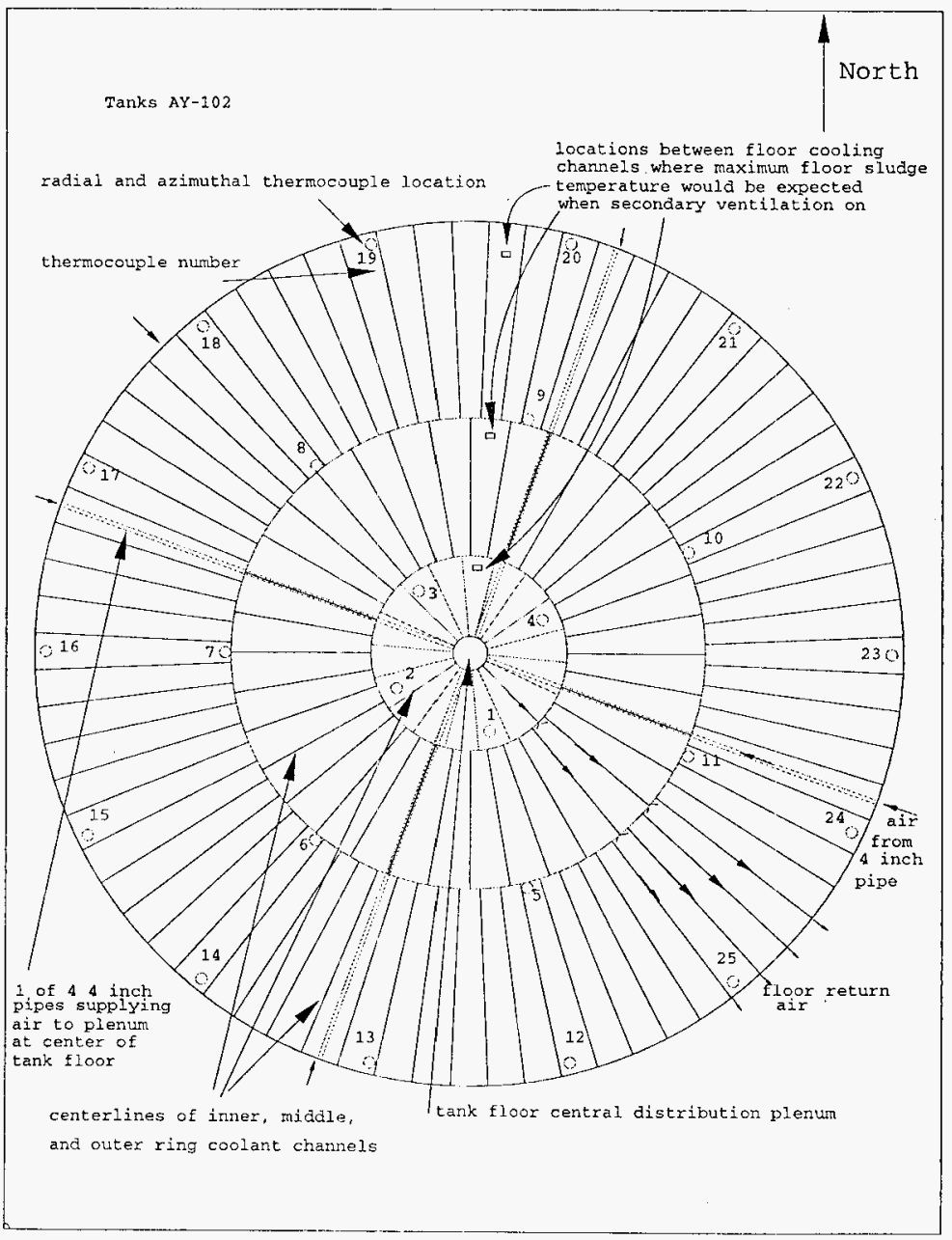


Details of the three different concrete floor channel sections are provided in Figure 2-3 together with a vertical side view of the location of the thermocouples relative to the primary tank steel floor.

A top view of the inlet ring manifold piping and filter system, together with side views of typical 4-inch and 6-inch drop lines, is shown in Figure 2-4.

Figures 2-1 through Figures 2-4 were drawn approximately to scale to provide a clear geometric perspective. Note that the vertical elevation of the horizontal 6-inch drop line in Figure 2-1 has been shifted downward from its actual position. The actual horizontal pipe centerline is at the same elevation as the horizontal section of the 4-inch drop line.

Geometric data for the following figures and models were obtained from (Sathyanarayana 1996b) and (Drawing Set 1).

Air is drawn into the inlet filters by the suction created by the exhaust fan located in the outlet portion of the secondary ventilation system. The air flows in the large diameter horizontal ring manifold illustrated in Figure 2-4, where it is distributed to either one of four 4-inch vertical drop lines leading to the floor channels, or one of four 6 -inch vertical drop lines leading to the upper region of the annulus. The series flow path of the 4-inch drop lines and the floor channels has much more flow resistance than the shorter and larger flow area 6-inch lines leading to the top of the annulus. Therefore, more of the flow would be expected to go directly to the top of the annulus rather than to the annulus via the floor channels.

Only the inlet portion of the secondary or annulus/floor ventilation system was considered in detail in this evaluation. This included the portion of the system from the inlet filters to the annulus between the primary and secondary tank walls. No detailed analysis of the outlet portion of the system from the annulus to the exhaust stack was conducted. However, the exhaust fan in the outlet portion of the ventilation system appears capable of producing significant vacuum levels in the annulus at quite high flow rates. This should be confirmed by detailed analysis of the outlet portion of the system, if increased vacuum in the annulus is selected as an option to obtain higher floor flow. If the current exhaust fan, when combined with the outlet piping, valves, dampers, filters, and stack, cannot meet the needed annulus vacuum at the flow desired, then an exhaust fan with higher head/flow requirements will have to be installed.

\subsection{GOTH SECONDARY VENTILATION SYSTEM NETWORK MODEL}

A description of the GOTH network model used to simulate the inlet portion of the secondary ventilation system is given in this section. This description includes the geometry and the basis for computing the pressure drop in terms of the pipe wall friction, and form losses for fittings, area changes, and filters. 
HNF-SD-W320-ER-002, Rev. 0

Figure 2-3. Tank Steel and Insulating Concrete Floor and

Floor Ventilation Channel Dimensions--Tank 241-AY-102.

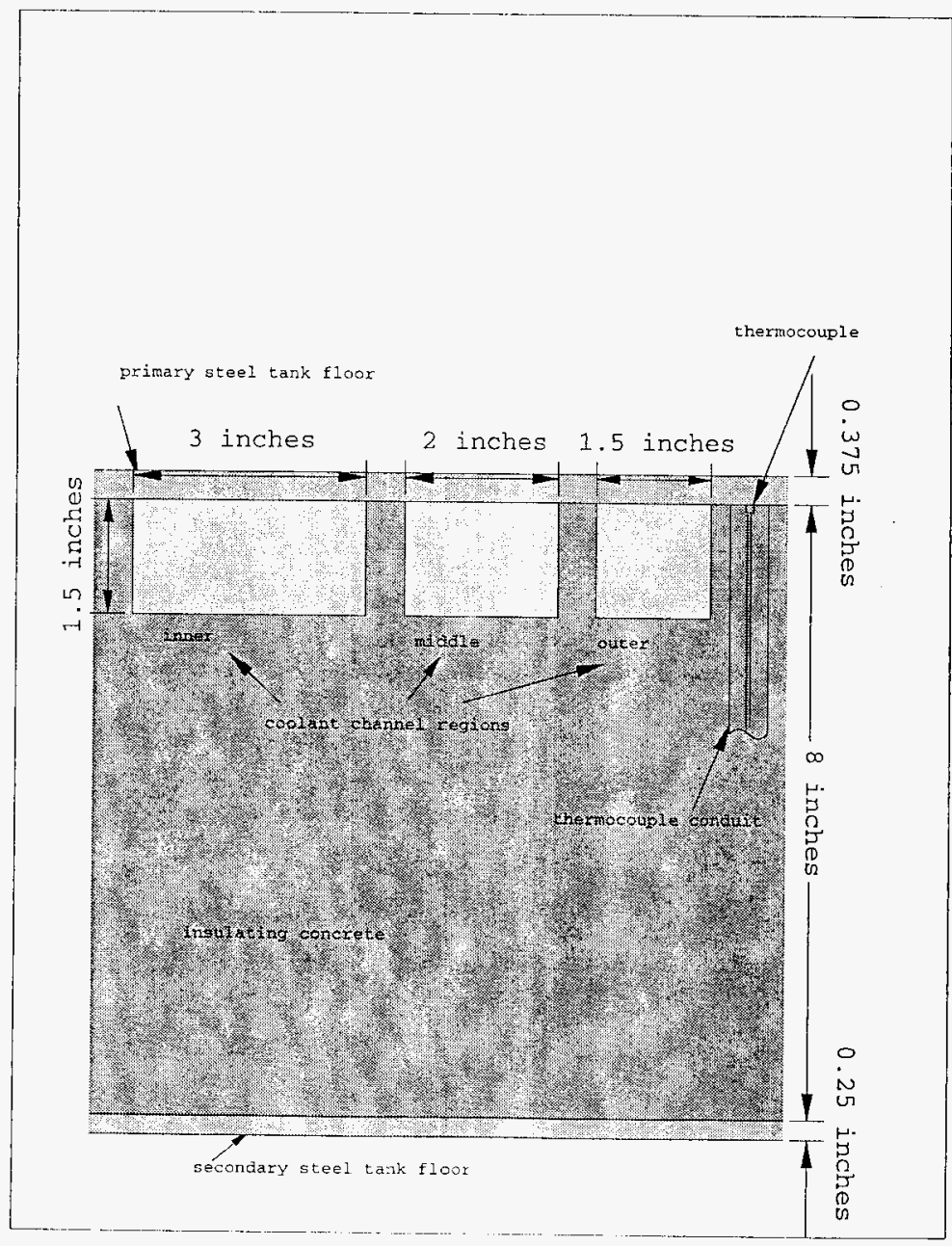


Figure 2-4. Secondary Ventilation Inlet Manifold, 6-Inch Drop Lines to Top of Annulus, and 4-Inch Drop Lines to Floor Ventilation Channels.

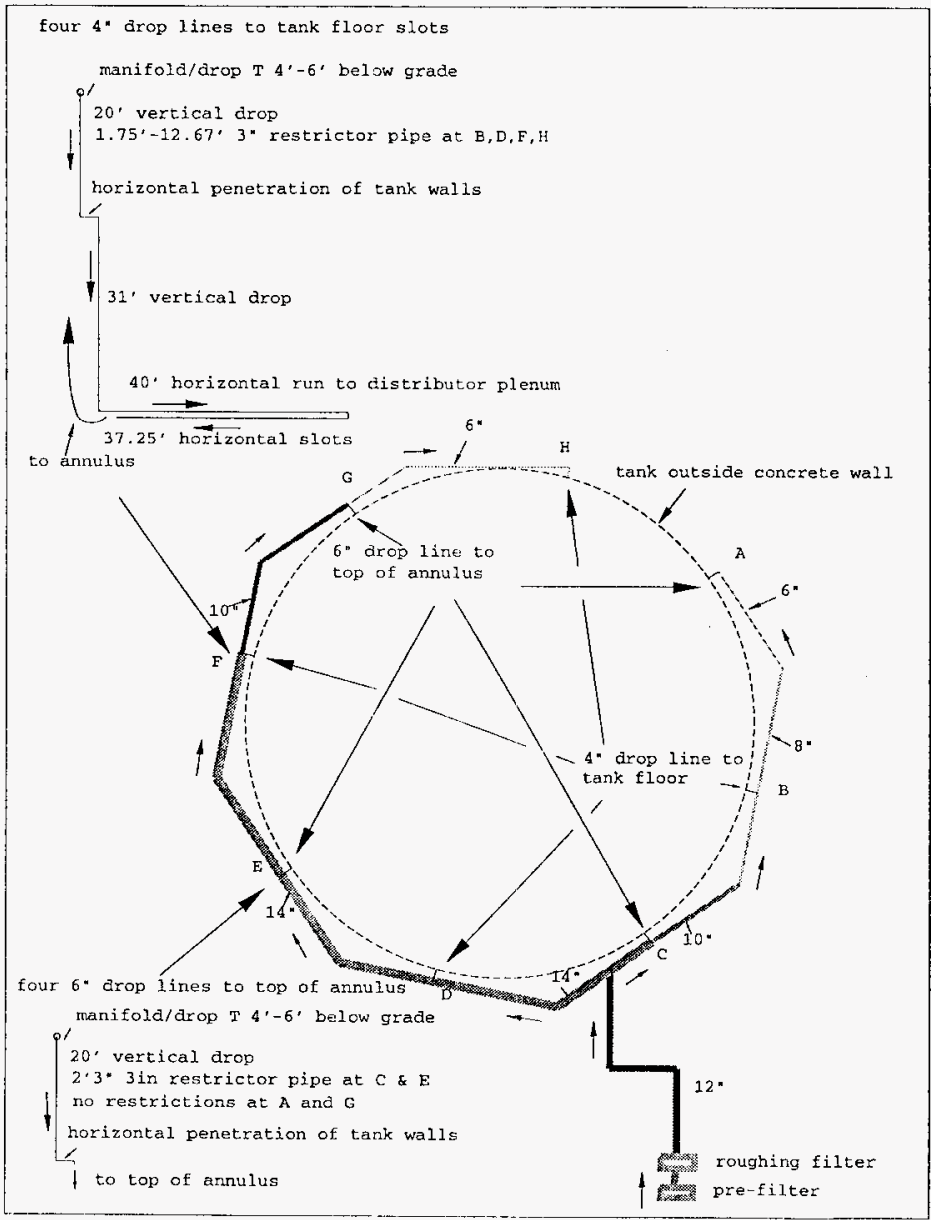




\subsubsection{Inlet Manifold Piping Runs and Drop Lines}

The GOTH (Thurgood 1993) network model of the inlet portion of the secondary ventilation system is illustrated in Figure 2-5 with piping and concrete floor channel lengths drawn approximately to scale. This model can be viewed as a partially unfolded version of the actual piping and concrete channel system illustrated in the above figures. The pipe size in each section is shown together with the approximate location of the various fitting and form losses.

Inlet pressure upstream of the filter was maintained at atmospheric pressure. Model outlet pressure corresponds to the annulus vacuum. Dummy volumes of $1 \mathrm{ft}^{3}$ were used to connect all four separate concrete channel exits to the annulus vacuum boundary condition. Similar dummy volumes were used to connect all flow path junctions. Frictional pipe and channel lengths, flow areas, duct roughness, and fitting and form losses were preserved for all flow paths. Each flow path was based on a discrete nominal pipe or concrete channel flow path area and hydraulic diameter.

No modeling of the secondary ventilation system downstream of the annulus toward the exhaust fan was included in the analysis. So the exhaust fan was assumed to be capable of producing the assumed annulus ventilation vacuum. Alternatively, the pressure difference between the inlet and the outlet to the model could be considered to be provided by any combination of inlet blower discharge pressure and annulus vacuum.

The model was used to simulate a slow transient wherein pressure in the annulus was decreased from atmospheric pressure to 100 in. w.g. vacuum over a period of 1000 seconds. Since dummy volumes and flow path inertial lengths were set to small values, their transient effects were minimized and the pressures and corresponding flow rates throughout the network at any point in time were approximately steady state. Flow rates and pressures, or pressure drops, over the 1000 -second simulation were then graphed against each other to obtain the near steadystate flow versus pressure drop characteristics of the system.

The model results were compared to Tank 241-AY-101 and Tank 241-AY-102 pressure drop and flow data. Although not identical, the Tank 241-AY-101 inlet part of secondary ventilation system is very similar to that of Tank $241-\mathrm{AY}-102$ system. The model was then used to evaluate the effect on floor flow of blocking the 6-inch drop lines between the ring manifold and the top of the annulus, and also of removing the 3 -inch restricter lines located in the 4-inch drop lines between the ring manifold and the floor channels. The model was used to evaluate the effect on floor flow of increasing the annulus vacuum, and adding an inlet blower to increase the inlet pressure. Combinations of these various means for increasing floor flow were also evaluated with this model. 
HNF-SD-W320-ER-002, Rev. 0

Figure 2-5. GOTH Series/Parallel Piping and Concrete Duet Secondary Ventilation Inlet Section Network Model.

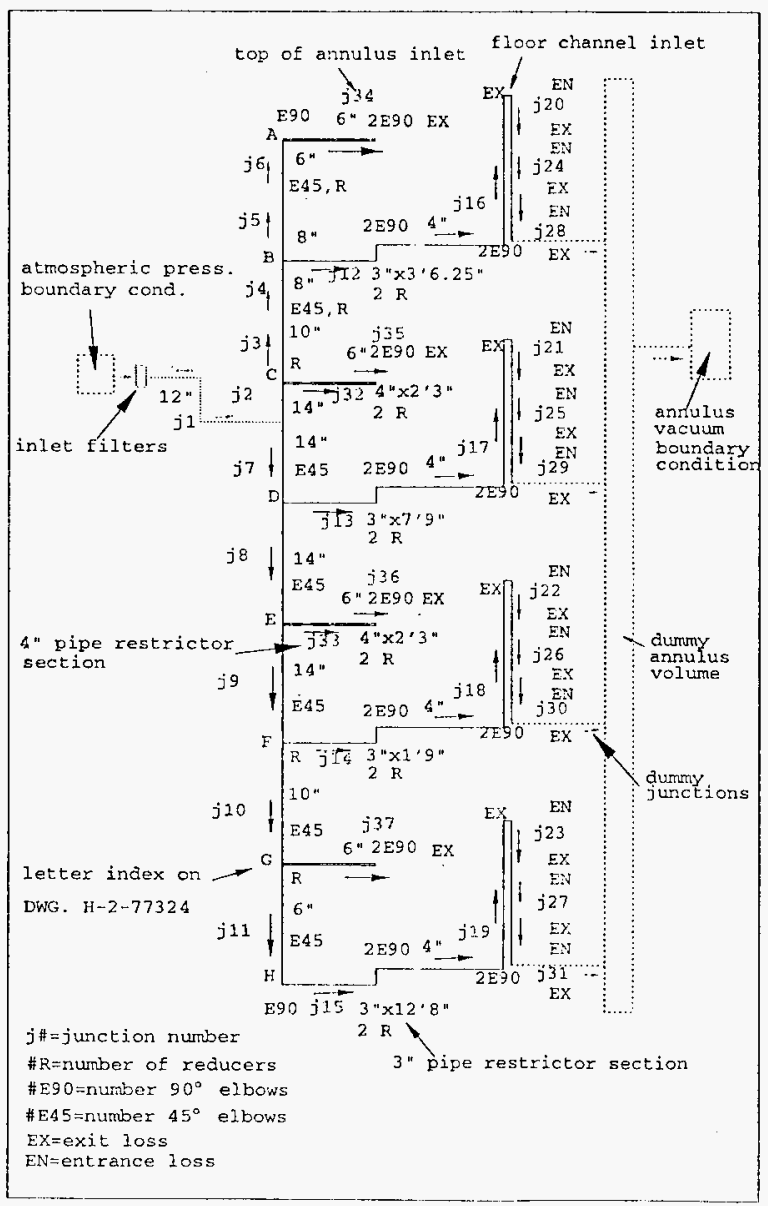




\subsubsection{Piping and Floor Channel Wall Fraction}

The flow is turbulent for all flow rates and the duct hydraulic diameter considered in this analysis. The Moody wall friction factor correlation as a function of pipe/duct hydraulic diameter, duct roughness, and Reynold's number for flow in pipes/ducts was utilized ((Zigrang and Sylvester 1985).

$$
\operatorname{fmoody} \epsilon d(\epsilon, d, \text { Rey })=0.0055\left(1+\left(2000\left(\frac{\epsilon}{d}\right)+\frac{10 \times 10^{05}}{R e y}\right)^{\frac{1}{3}}\right)
$$

The following roughnesses were assumed (Crane 1988) for carbon steel pipe and floor concrete channels,

Carbon steel:

$\epsilon \mathrm{cs}:=.00015 \mathrm{ft}$

Smooth concrete ducts:

$\epsilon$ cons: $=.001 \mathrm{ft}$

\subsubsection{Fittings, Other Form Losses, and Filter}

The following loss coefficients were used for the various pipe fittings and other form loss modeling (Crane 1988).

For the $45^{\circ}$ and $90^{\circ}$ elbows:

Kel45 (Dpipe) $=16 f_{\mathrm{T}}$ (Dpipe)

Kel90 (Dpipe) $=30 \mathrm{f}_{\mathrm{T}}($ Dpipe $)$

For pipe tees on the run and branch:

$\operatorname{KTr}($ Dpipe $)=20 f_{\mathrm{T}}$ (Dpipe)

$\mathrm{KTb}$ (Dpipe) $=60 \mathrm{f}_{\mathrm{T}}$ (Dpipe)

Where, for both elbows and tees, $f_{\mathrm{t}}$ is a function of the pipe diameter as given in Table 2-1. 
Table 2-1. Complete Turbulence Friction Factor--Commercial Steel Pipe.

\begin{tabular}{|c|c|c|c|c|c|}
\hline $\begin{array}{c}\text { Nominal pipe } \\
\text { size }\end{array}$ & 4 in. & $5 \mathrm{in.}$ & $6 \mathrm{in}$ & $8-10 \mathrm{in}$. & $12-16 \mathrm{in.}$ \\
\hline $\begin{array}{c}\text { Friction factor } \\
\left(\mathrm{f}_{\mathrm{T}}\right)\end{array}$ & 0.170 & 0.016 & 0.015 & 0.014 & 0.013 \\
\hline
\end{tabular}

For reducers, the loss coefficients are based upon flow in the smaller diameter pipe, $\mathrm{d} 1$, where the larger diameter pipe is $\mathrm{d} 2$.

For flow from a large diameter pipe to a small diameter pipe through a reducer:

$$
\operatorname{Krenc}(d 1, d 2)=\left(.5\left(1-\left(\frac{d 1}{d 2}\right)^{2}\right)\right)
$$

For flow from a small diameter pipe to a large diameter pipe through a reducer:

$$
\operatorname{Krexc}(d 1, d 2)=\left(\left(1-\left(\frac{d 1}{d 2}\right)^{2}\right)\right)^{2}
$$

For sudden expansion and contractions where $\mathrm{d} 1$ is small compared to $\mathrm{d} 2$ :

Expansion:

Kex: $=1$

Kcon: $=.5$

The inlet manifold is preceded by a roughing filter and also a pre-filter. Their characteristics when clean and dirty are provided in Figure 2-6 (Jennings 1996a).

For this analysis, the filters were assumed to be clean since the most recent data taken was for clean filters. Once a selection is made on the final secondary ventilation option to be used relative to transferring the tank 241-C-106 waste, and criteria for allowable pressure drops across these filters are established, then the analysis should be refined to include the maximum allowable pressure drop based on operations criteria. 
HNF-SD-W320-ER-002, Rev. 0

Figure 2-6. Secondary Ventilation Roughing Filter and Pre-Filter Hydraulic Characteristics.

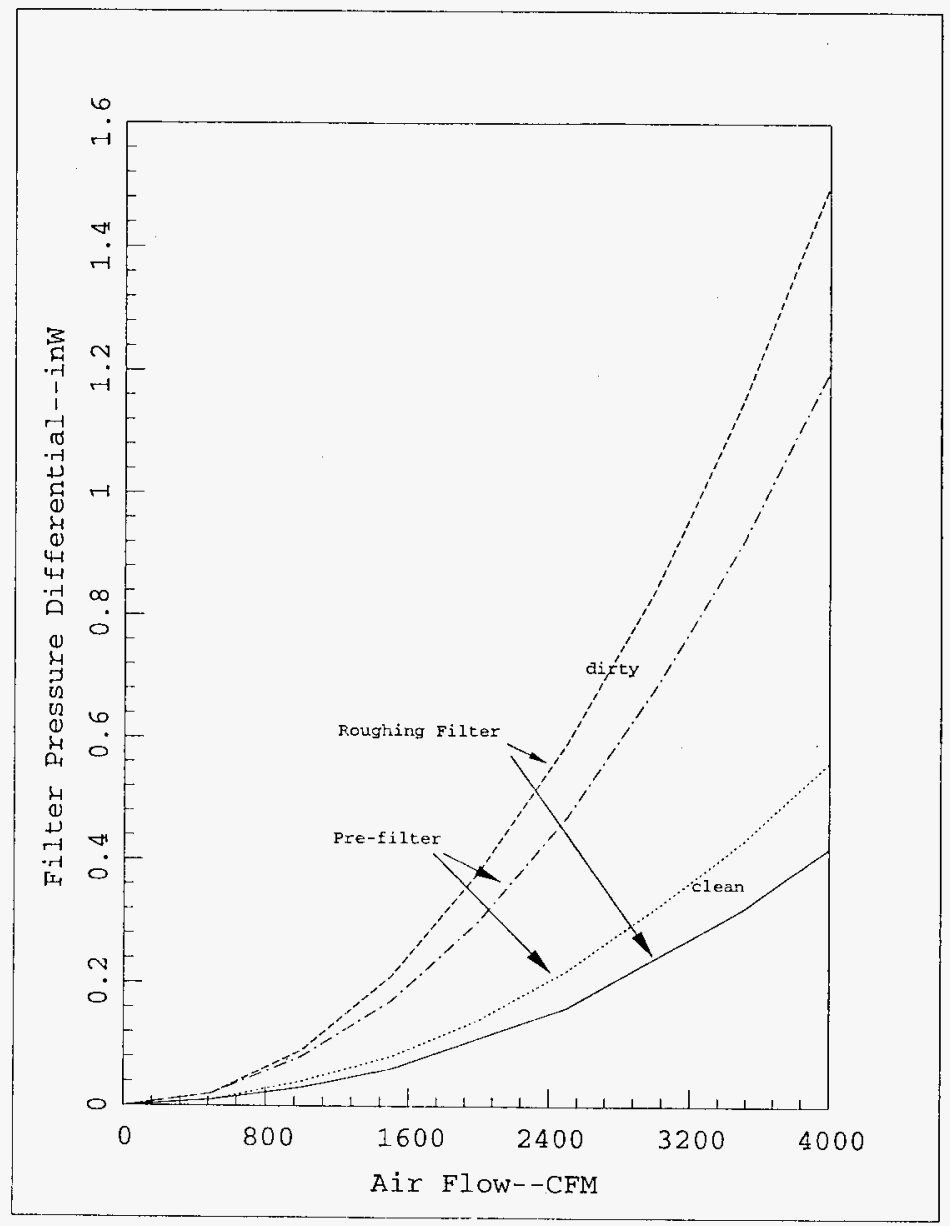




\subsubsection{Inlet Dampers}

Inlet dampers on the inlet portion of the secondary ventilation system were assumed to be fully open and to have negligible pressure loss.

\subsection{GOTH NETWORK MODEL VALIDATION}

The GOTH network model was validated using test data for the floor/annulus ventilation systems of Tanks 241-AY-101 and 241-AY-102. The results are discussed in this section.

\subsubsection{Tanks 241-AY-101 and 241-AY-102 Secondary Ventilation Data}

Pressure, pressure drop, and flow data for the secondary ventilation systems of Tank 241 AY-101 and Tank 241-AY-102 was taken following modifications to the inlet and outlet manifold piping systems on both tanks in the 1987-1988 time period. The pressure and flow data with 6-inch inlet drop lines, both unblocked (see Table 2-4) and blocked (see Table 2-5), was taken for Tank 241-AY-101. The annulus vacuum was recorded in this case as shown in these two tables. For Tank 241-AY-102, the pressure and flow data given in Table 2-3 was taken with 6 in. droplines unblocked. No data is available with blocked 6 in. droplines operation. However, the pressure data for Tank 24 I-AY-102, was taken for the inlet manifold, 4-inch drop lines (or floor data), and 6-inch drop lines (top of the annulus) for the unblocked case. Therefore, the pressure data (Table 2-3) for Tank 241-AY-102 is available only upstream and downstream of the annulus but not in the annulus. Estimates for the annulus vacuum present, when this data was taken, have been developed by comparison of upstream vacuum data to GOTH network model simulation results.

Recently, October 1996, following additional modifications, the flow and pressure data has been taken for Tank 241-AY-102, including annulus vacuum data (Table 2-2).

Although the secondary ventilation system of Tank 241-AY-101 has not been modeled, the measured data given in Tables 2-4 and 2-5 is considered here since the piping system is similar and the total quantity of data is very limited. 
Table 2-2. 1996 241-AY-102 Annulus Exhauster Startup Data--6-Inch Drop Lines Unblocked (Jennings 1996b).

\begin{tabular}{|c|c|}
\hline $\begin{array}{c}\text { Annulus pressure vacuum } \\
\text { (in. W.G.) }\end{array}$ & $\begin{array}{c}\text { Volumetric exhauster flow } \\
\left(\mathbf{f t}^{3} / \mathbf{m i n}\right)\end{array}$ \\
\hline 0.0 & 0.00 \\
\hline 1.5 & 1584.00 \\
\hline 4.0 & 2373.00 \\
\hline Array: jenning & \\
\hline
\end{tabular}

As noted above, the annulus vacuum was not recorded for the Tank 241-AY-102 unblocked 1987 tests. The annulus vacuum was estimated by comparisons to GOTH simulations. The model calculated annulus vacuum was $0.79 \mathrm{in}$. W.G. for model flow rates that produced 0.45 inches W.G. vacuum at the junction of the manifold and the 4-inch drop lines. For model flow rates that produced 0.63 in. W.G. at the junction of the manifold and the 6-inch drop lines, the calculated annulus vacuum was 1.08 in. W.G. Clearly, the annulus vacuum for the test was between $0.45 \mathrm{in}$. W.G., the minimum vacuum measured of all four 4-inch drop lines and the maximum vacuum of 1.14 in. W.G. measured in all of six 6-inch exhaust drop lines. It is, therefore, reasonable to assure that the annulus vacuum was approximately $0.79-1.08 \mathrm{in}$. W.G. as estimated by extrapolation using the GOTH simulation. 
HNF-SD-W320-ER-002, Rev. 0

Table 2-3. Tank 241-AY-102 1987 Data--6-Inch Drop Lines Unblocked (Powell 1989).

\begin{tabular}{|c|c|c|c|c|c|}
\hline Location & $\begin{array}{l}\text { Vacuum } \\
\text { measured }\end{array}$ & $\begin{array}{l}\text { Annulus } \\
\text { pressure } \\
\text { vacuum } \\
\text { assumed } \\
\text { (in. W.G.) }\end{array}$ & $\begin{array}{c}\text { Volumetric } \\
\text { floor flow } \\
\mathrm{ft}^{3} / \mathrm{min}\end{array}$ & $\begin{array}{l}\text { Volumetric } \\
\text { annulus } \\
\text { inlet flow } \\
\left(\mathrm{ft}^{3} / \mathrm{min}\right)\end{array}$ & $\begin{array}{l}\text { Total } \\
\text { flow }\end{array}$ \\
\hline 4 in. drop & .45 & 0.45 & 210.00 & 988.00 & 1198.00 \\
\hline 6 in. drop & .63 & 0.63 & 210.00 & 988.00 & 1198.00 \\
\hline $\begin{array}{l}\text { Annulus - extp. } \\
\text { from } 4 \text { in. drop } \\
\text { Annulus - extp. } \\
\text { from } 6 \text { in. drop } \\
6 \text { in. exhaust }\end{array}$ & 1.14 & $\begin{array}{l}0.79 \\
1.08 \\
1.14\end{array}$ & $\begin{array}{l}210.00 \\
210.00 \\
210.00\end{array}$ & $\begin{array}{l}988.00 \\
988.00 \\
988.00\end{array}$ & $\begin{array}{l}1198.00 \\
1198.00 \\
1198.00\end{array}$ \\
\hline
\end{tabular}

Table 2-4. Tank 241-AY-101 1988 Data--6-Inch Drop Lines Unblocked (Nordquist 1988a).

\begin{tabular}{|c|c|c|c|}
\hline $\begin{array}{l}\text { Annulus pressure } \\
\text { vacuum } \\
\text { (in. W.G.) }\end{array}$ & $\begin{array}{l}\text { Volumetric floor } \\
\text { flow } \\
\left(\mathrm{ft}^{3} / \mathrm{min}\right)\end{array}$ & $\begin{array}{l}\text { Volumetric annulus } \\
\text { inlet flow } \\
\left(\mathrm{ft}^{3} / \mathrm{min}\right)\end{array}$ & $\begin{array}{r}\text { Volumetric total } \\
\text { flow } \\
\left(\mathrm{ft}^{3} / \mathrm{min}\right)\end{array}$ \\
\hline 0.51 & 180.00 & 669.00 & 849.00 \\
\hline
\end{tabular}

For the blocked 6 inch drop lines test of Tank 241-AY-101, there was a difference between the total flow at the system inlet and that measured at the 4-inch inlet drop lines. Both values are shown in the Table 2-5. 
HNF-SD-W320-ER-002, Rev. 0

Table 2-5. Tank 241-AY-101 1988 Data--6-Inch Drop Lines

Blocked (Nordquist 1988b).

\begin{tabular}{|c|c|}
\hline $\begin{array}{c}\text { Annulus pressure--vacuum } \\
\text { (in. W.G.) }\end{array}$ & $\begin{array}{c}\text { Volumetric exhauster flow } \\
\left(\mathrm{ft}^{3} / \mathrm{min}\right)\end{array}$ \\
\hline \hline 1.5 & 512.00 \\
\hline 1.5 & 403.00 \\
\hline
\end{tabular}

\subsubsection{Network Model Comparisons to Tank Data}

The results of the GOTH network simulation model and the data discussed above are shown in Figure 2-7 for the 6-inch unblocked drop line mode of operation and in Figure 2-8 for the 6 -inch blocked drop line mode of operation. As can be observed from Figure 2-7, the GOTH network model results agree quite well with the data for total, annulus (i.e., 6-inch drop lines), and floor (4-inch drop lines) in the unblocked 6-inch drop line mode of operation. Good comparison of the total or floor flow with the measured data was also obtained for the results in the 6-inch drop line blocked mode of operation. It should be noted that no tuning of this model in terms of adding or removing artificial flow resistances has been incorporated into this model. These results were obtained based on the geometry and flow resistance modeling approach described in this section.

\subsection{ANNULUS/FLOOR VENTILATION SYSTEM PERFORMANCE}

Limited flow data is available for determining total, annulus, and floor flow rates under different operating conditions. The above described GOTH model was used to evaluate the various options for increasing the tank floor flow. These included increasing the annulus vacuum or adding an inlet blower, blocking the 6 -inch lines, and removing the 3 -inch restrictions from the 4-inch drop lines to the floor channels.

\subsubsection{Current System with Annulus Vacuum Restrictions, 6-Inch Drop Lines Unblocked and Blocked.}

It would be desirable to achieve high floor flow rates without modifying the ventilation system or changing the operating restrictions. GOTH network model predictions of air flow to the floor and annulus are shown in Figure 2-9 for both blocked and unblocked 6 in. Drop lines. and the restriction that the annulus vacuum must be lower than the dome vacuum. It is seen from the Figure 2-9 that the simulated floor flow under current secondary ventilation system operating condition of maintaining an annulus vacuum at $0.5 \mathrm{in}$. W.G. is 155 and $233 \mathrm{cfm}$ for unblocked and blocked 6 in. drop line cases respectively. Under the Project W-030, it will likely be difficult to achieve a lower pressure in the dome than 0.5 in. W.G. vacuum. Tanks in the AZ/AY tank farm typically operate at about 2-2.5 in. W.G. dome vacuum with an estimated tank in leakage flow of about $600 \mathrm{cfm}$. Under Project W-030 operation, total Tank $241-A Y-102$ dome inflow 
may be limited to $100 \mathrm{cfm}$. Sealing up Tank $241-A Y-102$ in leakage paths to achieve a tank dome vacuum greater than 0.5 in. W.G. at these low flow rates may be very difficult.

Under current operating conditions, most of the secondary ventilation bypasses the floor channels by flowing from the ring manifold directly to the top of the annulus via the 6-inch drop lines as illustrated in Figure 2-10. If these lines were plugged, the floor flow rate via the 4-inch drop lines would increase to $233 \mathrm{cfm}$ at $.5 \mathrm{in}$. W.G. annulus vacuum as shown in Figure 2-7. 
HNF-SD-W320-ER-002, Rev. 0

Figure 2-7. Volumetric Flow vs. Annulus Vacuum with Atmospheric Inlet Pressure--6-Inch Annulus Inlet Lines.

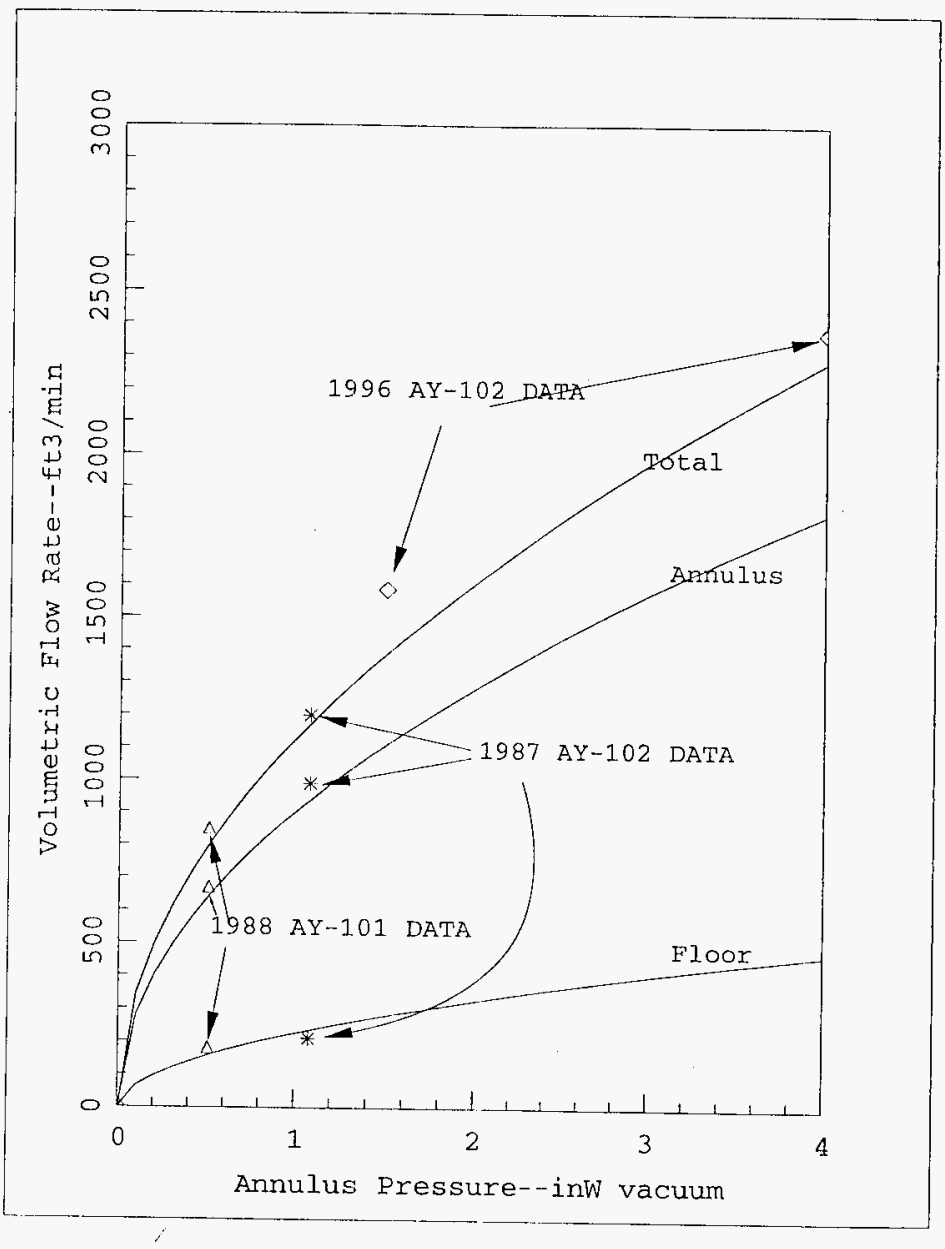


HNF-SD-W320-ER-002, Rev. 0

Figure 2-8. Volumetric Flow vs. Annulus Vacuum with Atmospheric Inlet Pressure.

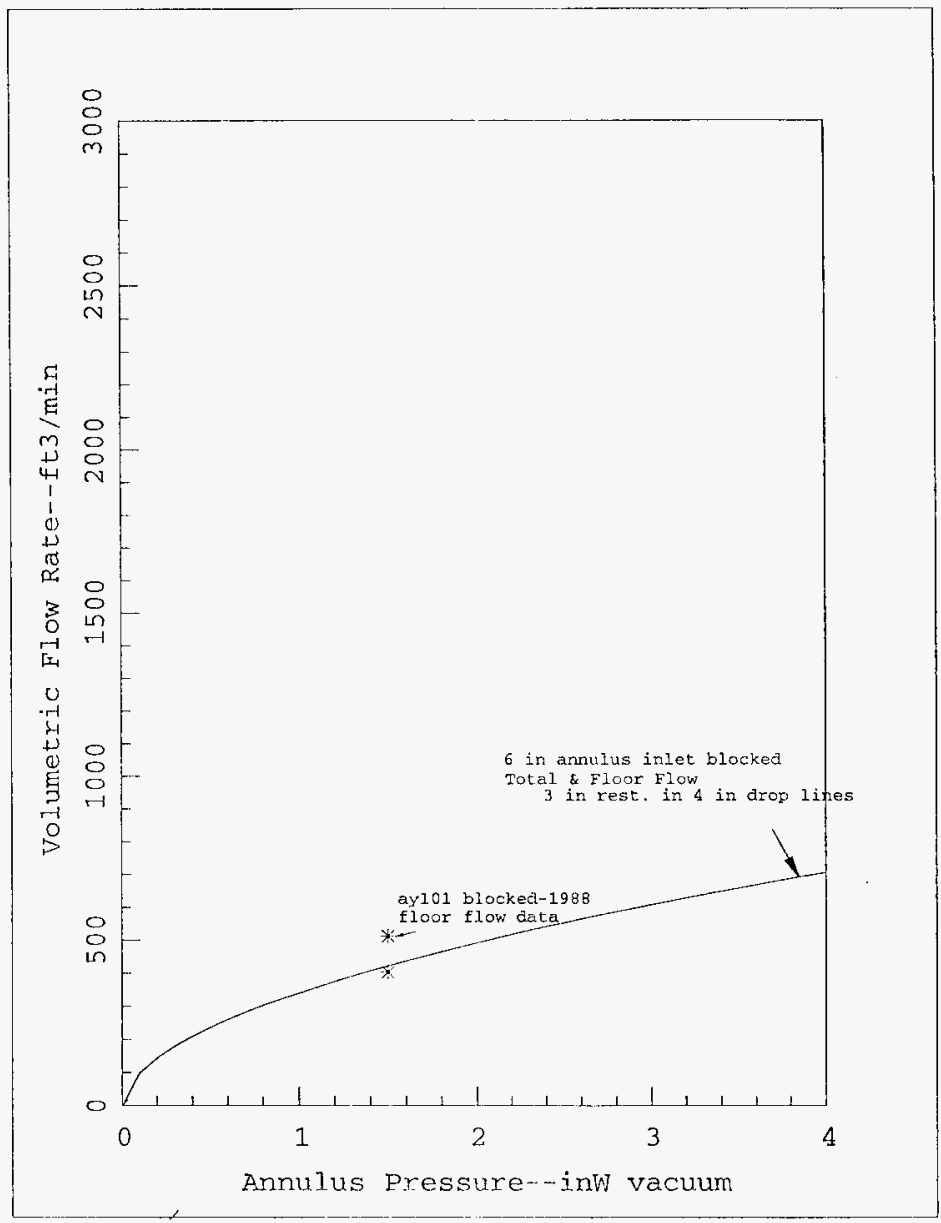


HNF-SD-W320-ER-002, Rev. 0

Figure 2-9. Floor Volumetric Flow vs. Annulus Vacuum with Atmospheric Inlet Pressure-6-Inch Annulus Inlet Lines Blocked and Unblocked.

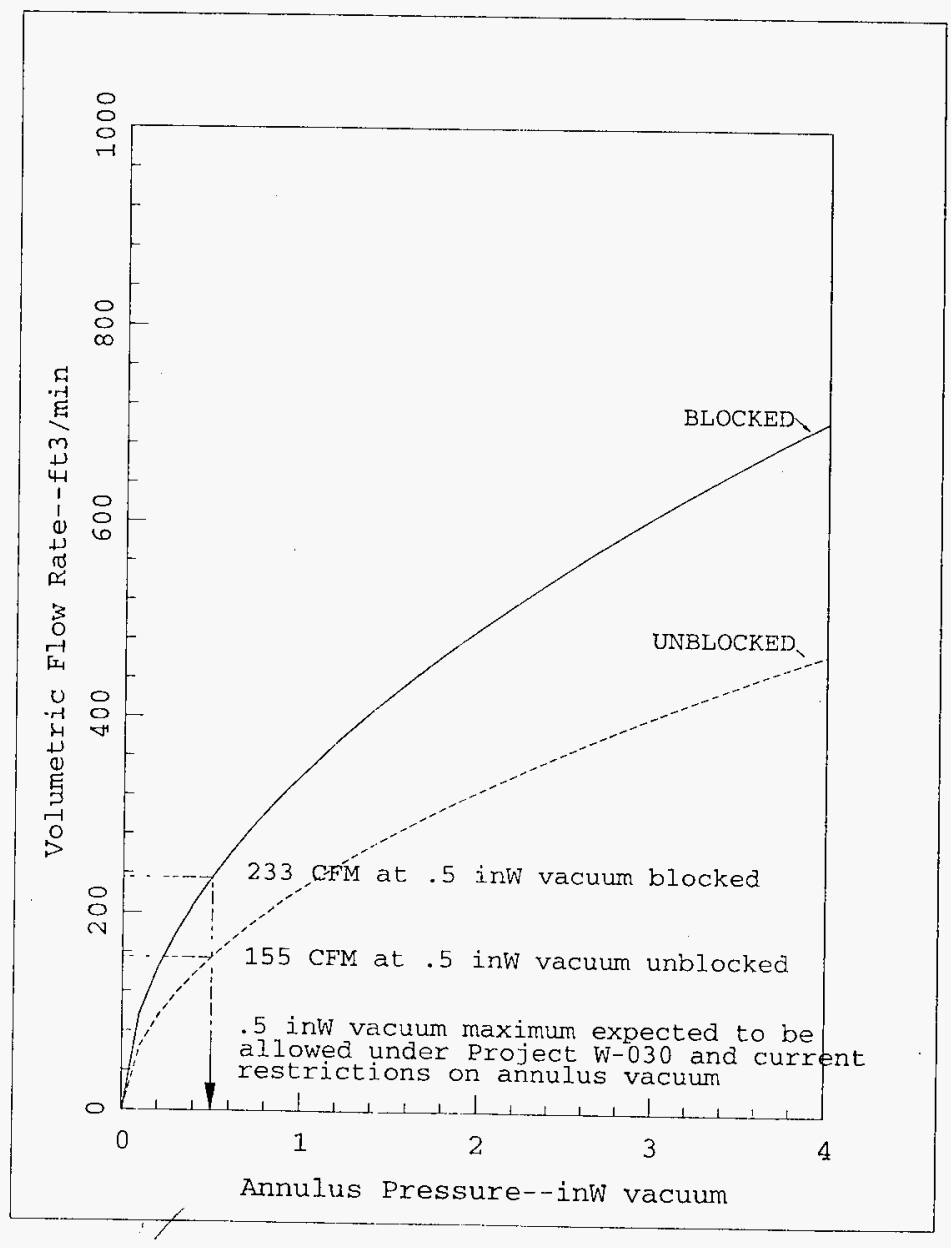


HNF-SD-W320-ER-002, Rev. 0

Figure 2-10. Volumetric Flow vs. Annulus Vacuum with Atmospheric Inlet Pressure.

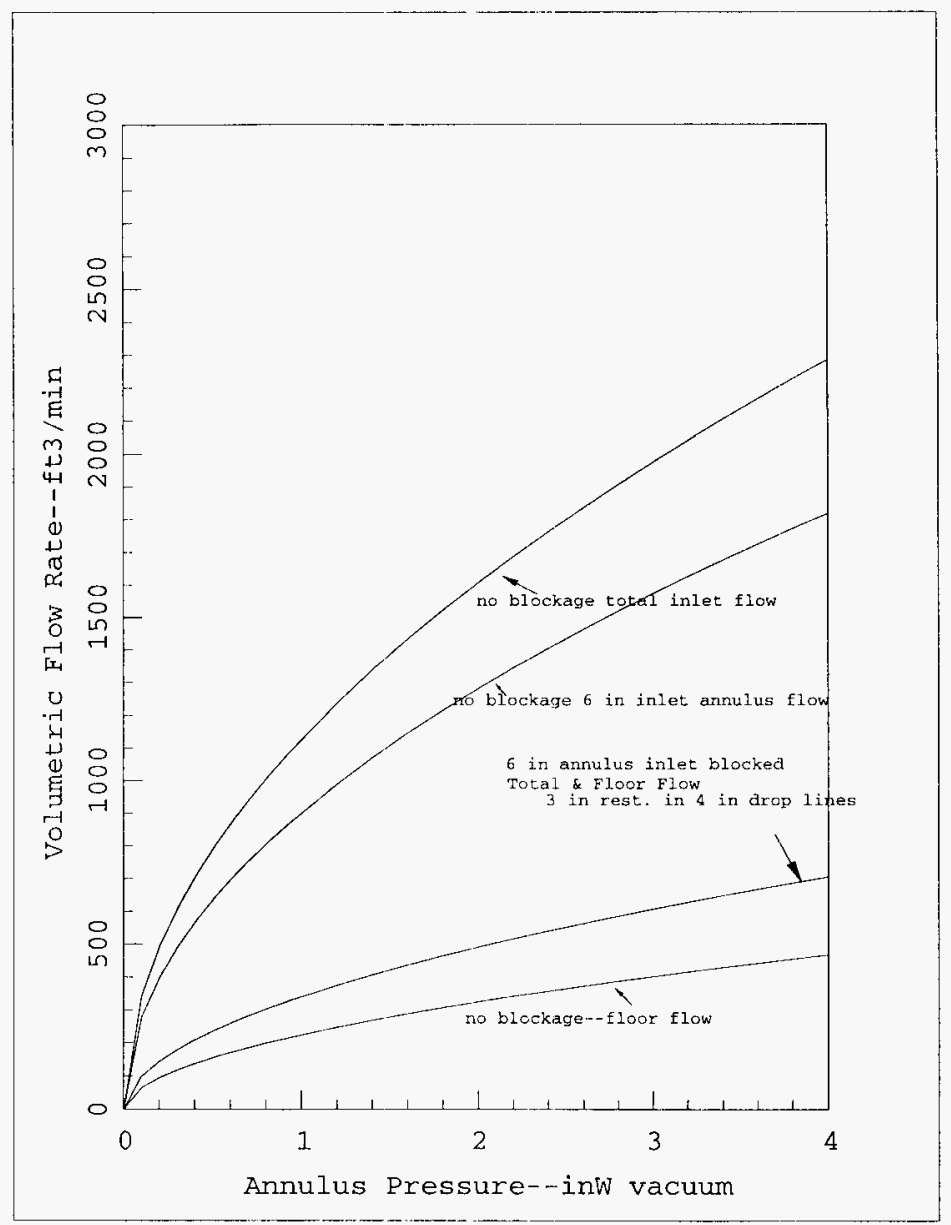




\subsubsection{Inlet Blower--Unblocked and Blocked 6-Inch Drop Lines.}

In order to achieve significantly higher floor air flows, the pressure difference between the secondary ventilation inlet and the annulus must be significantly increased even if the 6 -inch drop lines are blocked as illustrated in Figure 2-11. It may be possible to achieve on the order of 12 in. W.G. annulus vacuum with the current system, particularly if the 6 -inch drop lines are blocked. However, further analysis of the outlet portion of the secondary system is required to confirm this. Maintaining the annulus at 12 in. W.G. vacuum, it is estimated that the floor flow could be increased to 821 and $1239 \mathrm{cfm}$ for 6-inch drop lines unblocked and blocked conditions respectively. Obtaining floor flow rates up to the $2000 \mathrm{cfm}$, assumed in the prior analysis, it would require the use of an inlet blower, possibly in combination with higher annulus vacuum, depending on the head/flow characteristics of the blower and whether or not the 6-inch drop lines are blocked. Clearly, to obtain $2000 \mathrm{cfm}$ floor flow without increasing the annulus vacuum, and without blocking, a very high head blower would be required.

\subsubsection{Blockage of all 6-Inch Annulus Inlet Drop Lines Plus Removal of 3-Inch Pipe Restrictions in 4-Inch Floor Inlet Drop Lines.}

The 4-inch drop lines from the ring manifold to the floor channels contain 3-inch sections of pipe whose apparent purpose was to distribute flow evenly to each pipe. These 3 -inch sections produce increased resistance to flow. It was reasoned that these sections could be removed simultaneously during the excavation that may be required to block the 6 -inch lines. The retwork model was revised to remove the flow restriction resulting from the 3 -inch pipe sections, and the results are illustrated in Figure 2-12. As noted, there is little gain in flow as a result of removing the 3 -inch pipe sections. 
HNF-SD-W320-ER-002, Rev. 0

Figure 2-11. Floor Volumetric Flow vs. Annulus Vacuum or System Pressure Drop--6-Inch Annulus Inlet Lines Blocked and Unblocked.

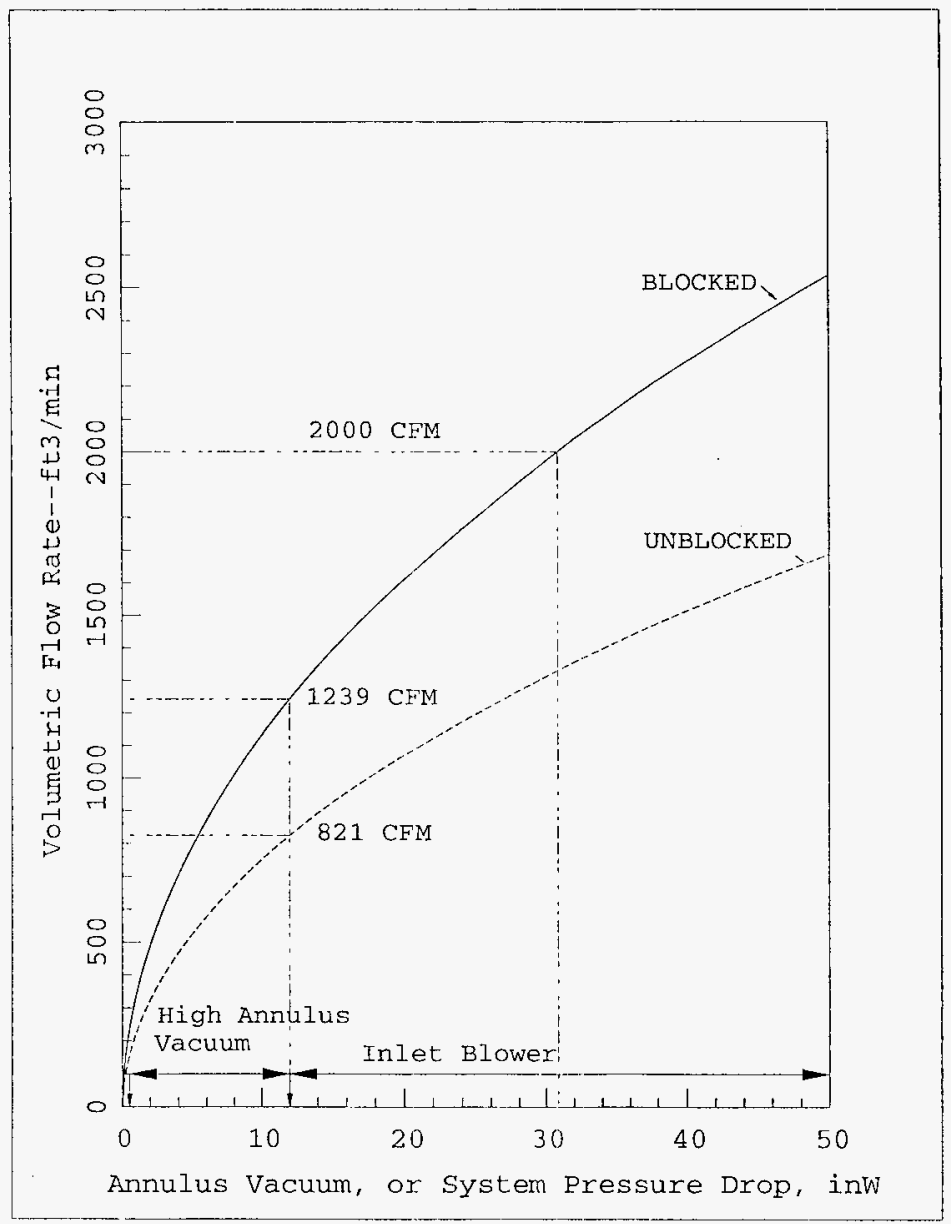


HNF-SD-W320-ER-002, Rev. 0

Figure 2-12. Volumetric Flow vs. Annulus Vacuum with Atmospheric Inlet Pressure.

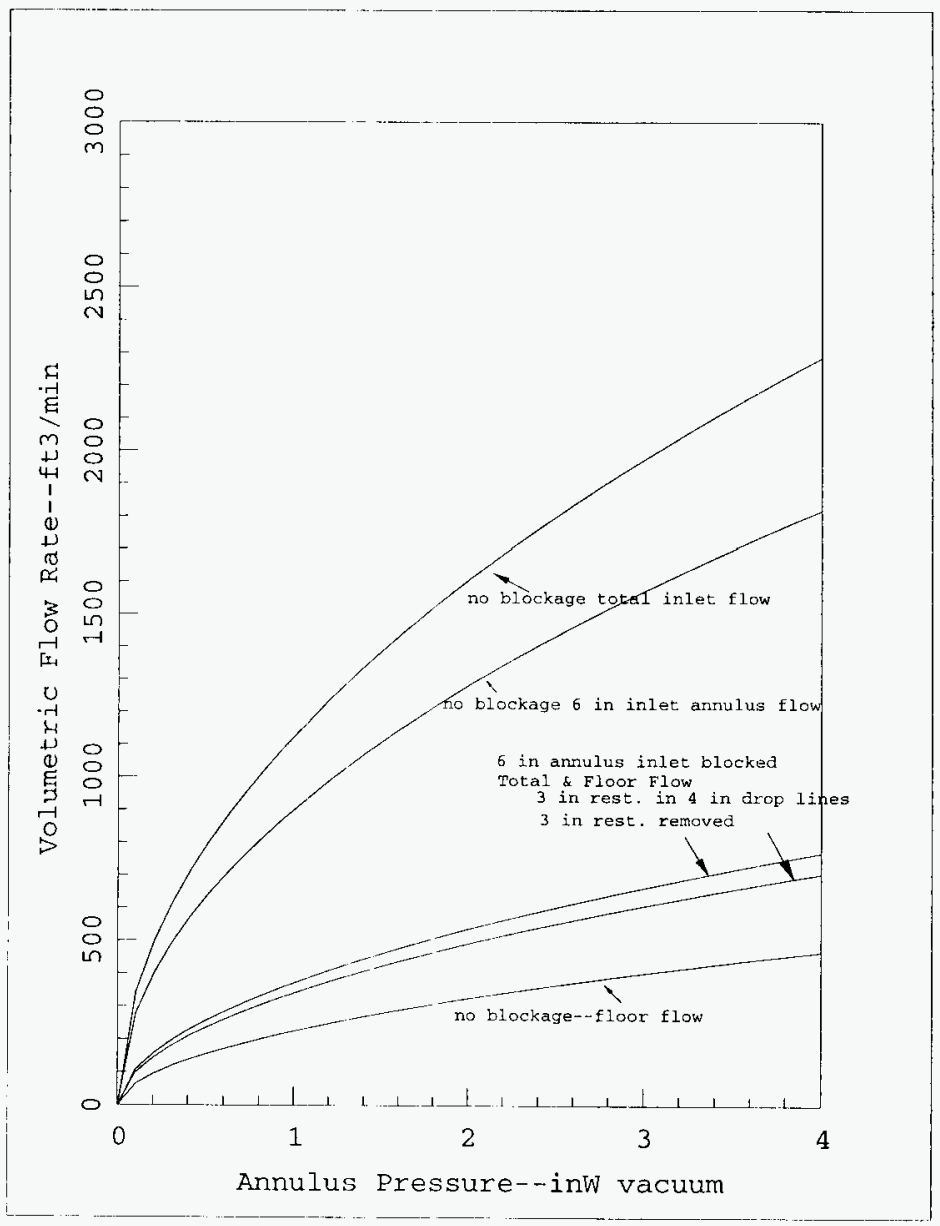




\subsubsection{Blockage of Three 6-Inch Drop Lines.}

A concern was raised that blockage of all of the four 6-inch drop lines might not be possible, and that this might reduce the incentive for attempting to block any of these drop lines. The network model was revised to include the blockage of all 6-inch drop lines except location " $\mathrm{G}$ " on Figures 2-4 and 2-5. The results are illustrated in Figure 2-13. As noted, the decrease in floor flow when three 6 -inch drop lines are blocked rather than four, is somewhat significant. It should also be noted that the flow through the one unblocked 6-inch drop line is about the same as flow to the floor in this case. Floor, annulus, and total flow for the no blockage case described above is shown for comparison.

\subsubsection{Summary Table of Cases.}

Table 2-6 summarizes the alternative means for increasing floor flow considered in this evaluation. Based on this table and the above graphs, modifications in the inlet portion of the secondary ventilation system, together with possible modifications in allowed annulus vacuum as well as positive pressure locations in this system are required to obtain significant increases in floor flow. It is also noted that the fan hydraulic horsepower requirements can be significant at high flow rates. 
Table 2-6. Annulus Vacuum, Blower Discharge Pressure, Flow Rate at Floor And Total, Piping Network Options.

\begin{tabular}{|c|c|c|c|c|c|c|c|c|c|}
\hline $\begin{array}{l}6 \text { inch Drop } \\
\text { Lines }\end{array}$ & $\begin{array}{l}3 \text { "line } \\
\text { in place. }\end{array}$ & $\begin{array}{l}\text { Floor flow } \\
\text { rate } \\
\text { (ft3/min) }\end{array}$ & $\begin{array}{l}\text { Total flow } \\
\text { rate } \\
\text { (tt/min) }\end{array}$ & $\begin{array}{l}\text { Total } \\
\text { pressure } \\
\text { drop } \\
\text { (in.W.G.) }\end{array}$ & $\begin{array}{l}\text { Annulus } \\
\text { vacuum } \\
\text { (in.W.G.) }\end{array}$ & $\begin{array}{l}\text { Blower } \\
\text { discharge } \\
\text { pressure } \\
\text { (in.w.G.) }\end{array}$ & $\begin{array}{l}\text { Annulus } \\
\text { vacuum } \\
\text { (in.W.G.) }\end{array}$ & $\begin{array}{l}\text { Blower } \\
\text { discharge } \\
\text { pressure } \\
\text { (in.W.G.) }\end{array}$ & $\begin{array}{c}\text { Hydraulic } \\
\text { horsepower } \\
\text { (hp) }\end{array}$ \\
\hline Unblocked & Yes & 155 & 787 & 0.50 & -0.50 & 0.00 & -0.50 & 0.00 & 0.06 \\
\hline Unblocked & Yes & 400 & 1966 & 2.97 & -0.50 & 2.47 & -2.97 & 0.00 & 0.9 \\
\hline Unblocked & Yes & 600 & 2916 & 6.47 & -0.50 & 5.97 & -6.47 & 0.00 & 3.0 \\
\hline Unblocked & Yes & 750 & 3627 & 9.97 & -0.50 & 9.47 & -9.97 & 0.00 & 5.7 \\
\hline Unblocked & Yes & 825 & 3982 & 12.00 & -0.50 & 11.50 & -12.00 & 0.00 & 7.5 \\
\hline Unblocked & Yes & 1000 & 4809 & 17.50 & -0.50 & 17.00 & -12.00 & 5.50 & 13.3 \\
\hline Unblocked & Yes & $16: 2$ & 7701 & 45.50 & -0.50 & 45.00 & -12.00 & 33.50 & 55.2 \\
\hline Unblocked & Yes & 1822 & 8700 & 58.58 & -0.50 & 58.08 & -12.00 & 46.58 & 80.3 \\
\hline Unblocked & Yes & 1985 & 9476 & 70.08 & 0.00 & 0.00 & -12.00 & 58.08 & 104.7 \\
\hline Blocked & No & 256 & 256 & 0.50 & -0.50 & 0.00 & -0.50 & 0.00 & 0.02 \\
\hline Blocked & No & 700 & 700 & 3.34 & -0.50 & 2.84 & -3.34 & 0.00 & 0.4 \\
\hline Blocked & No & 750 & 750 & 3.81 & -0.50 & 3.31 & -3.81 & 0.00 & 0.5 \\
\hline Blocked & No & 850 & 850 & 4.84 & -0.50 & 4.34 & -4.84 & 0.00 & 0.7 \\
\hline Blocked & No & 1000 & 1000 & 6.63 & -0.50 & 6.13 & -6.63 & 0.00 & 1.1 \\
\hline Blocked & No & 1200 & 1200 & 9.45 & .0 .50 & 8.95 & .9 .45 & 0.00 & 1.8 \\
\hline Blocked & No & 1400 & 1400 & 12.77 & -0.50 & 12.27 & -12.00 & 0.77 & 2.8 \\
\hline Blocked & No & 2000 & 2000 & 25.87 & -0.50 & 25.37 & -12.00 & 13.87 & 8.2 \\
\hline Blocked & No & 2200 & 2200 & 31.26 & -0.50 & 30.76 & -12.00 & 19.26 & 10.8 \\
\hline Blocked & No & 2500 & 2500 & 40.40 & -0.50 & 39.90 & -12.00 & 28.40 & 15.9 \\
\hline Blocked & No & 3000 & 3000 & $\$ 8.58$ & -0.50 & 58.08 & -12.00 & 46.58 & 27.7 \\
\hline Blocked & No & 3272 & 3272 & 70.08 & 0.00 & 0.00 & -12.00 & 58.08 & 36.2 \\
\hline $\begin{array}{l}3 \text { Lines } \\
\text { Blocked }\end{array}$ & Yes & 211 & 457 & 0.50 & -0.50 & 0.00 & -0.50 & 0.00 & 0.04 \\
\hline
\end{tabular}


HNF-SD-W320-ER-002, Rev. 0

Figure 2-13. Volumetric Flow vs. Annulus Vacuum with Atmospheric Inlet Pressure.

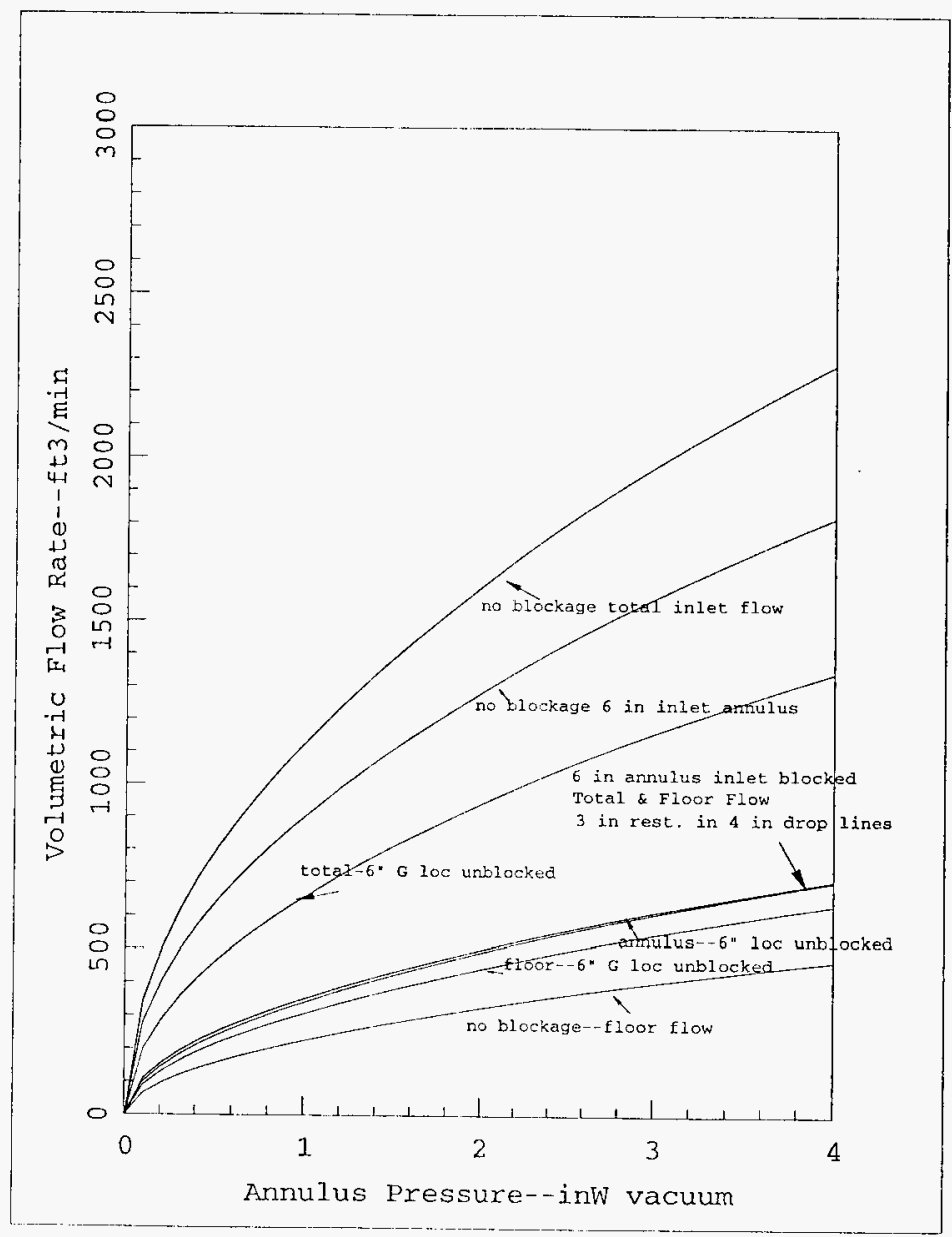


HNF-SD-W320-ER-002, Rev. 0

\subsection{TANK 241-AY-102 THERMAL EVALUATION}

Project W-320 plans to retrieve high heat waste from a single shell Tank 241-C-106 and transfer to a double-shell Tank 241-AY-102 for interim storage. The insoluble solids in the transferred slurry will settle out and increase the sludge volume and the heat load in Tank 241AY-102. For the current operating conditions of the tank, the increased sludge volume and the heat load will increase the waste temperatures in Tank 241-AY-102. The maximum sludge temperature is required to be less than $30^{\circ} \mathrm{F}$ below local saturation or boiling temperature. Thermal analyses were performed to estimate the potential quantity of Tank 241-C-106 sludge that can be transferred to Tank 241-AY-102 without exceeding the safety limits on peak sludge temperature. The quantity of sludge that can be safely stored in Tank 241-AY-102 depends on settled sludge thickness, the heat generation rate and the cooling effectiveness of the secondary ventilation flow for the given primary ventilation system either 702-A or W-030. Based on the assumption that the current secondary ventilation system is capable of delivering about 2000 to $3000 \mathrm{cfm}$ flow to the tank floor cooling channels (Tardiff 1995a and 1995b), prior thermal analysis (Sathyanarayana, 1996b) estimated that about 158,600 gallons (4.8 ft) of Tank 241-C106 sludge with a heat load of $92,400 \mathrm{Btu} / \mathrm{h}$ can be stored in Tank $241-\mathrm{AY}-102$ without exceeding the temperature limits. However, as described in the previous section, the current secondary ventilation system can only deliver about $150 \mathrm{cfm}$ flow to the tank floor cooling slots. In view of this reality, the thermal analyses were performed to determine the required modifications of secondary ventilation system for the safe storage of Tank 241-C-106 sludge in Tank 241-AY-102. Also, calculations were performed to estimate the potential maximum quantity of sludge transfer under current operating conditions of the secondary ventilation system. The results of these thermal analyses are presented in this section.

\subsection{HUB MODEL DESCRIPTION}

The HUB thermal analysis is based on a model that considers one-dimensional, steady state heat conduction for the settled sludge and accounts for the effects of heat loss due to primary ventilation flow and tank bottom slot cooling flow. The model assumes a uniformly distributed heat source in the heat conducting medium. The heat conducting medium consists of two layers of nonconvective, settled sludge and a layer of supernate on top. The bottom layer represents 32,000 gallons (Hanlon 1996) of current sludge in Tank 241-AY-102, and the second layer represents the transferred Tank 241-C-106 waste that has settled to a nonconvective state. Each of these two layers has its own thickness, thermal conductivity, heat source, and density. The heat loss due to the primary ventilation flow and that due to the secondary (annulus) ventilation flow, particularly that due to the air flow through the air slots at the bottom, are simultaneously included in the model. The evaporation of supernate at the pool/dome air interface is modeled through the correlation of Boelter, et al. 1946, developed for the calculation of water evaporation rates in a quiet atmosphere by natural convection. The heat loss to the annulus flow in the tank bottom air slots is included in the calculations through an effectiveness parameter. 
The cooling channel effectiveness was defined as the ratio of the increase in cooling air temperature to the maximum possible air temperature rise if the air reaches the sludge bottom temperature. The zero effectiveness corresponds to an adiabatic boundary condition at the bottom, and 100\% effectiveness represents the case where the air flow in the slots will reach the sludge bottom temperature. Obviously, with the adiabatic boundary, the estimated peak sludge temperature will be higher and with $100 \%$ effectiveness the peak sludge temperature will be lower. In reality, the peak sludge temperature will be somewhere in between. In order to arrive at a realistic effectiveness parameter, a two-dimensional calculation (Sathyanarayana 1996b) using the GOTH computer code was performed. Based on the results of this analysis for 2500 $\mathrm{cfm}$ flow and the calculation described in the next section for $250 \mathrm{cfm}$ flow through the air cooling slots, the effectiveness parameter values of 0.35 and 0.70 , respectively were used. The 2-D GOTH model is discussed in section 3.2.

The air inlet flow conditions for the primary ventilation flow with the 702-A system were assumed to be $630 \mathrm{cfm}$ flow, $70^{\circ} \mathrm{F}$ temperature and $50 \%$ relative humidity. For the Project W030 system, the effective air inlet flow conditions of $500 \mathrm{cfm}$ flow with $76^{\circ} \mathrm{F}$ and $75 \%$ relative humidity were used (see Table 3-1).

The heat load distribution in Tank 241-C-106 waste has been established (Bander 1993) to be nonuniform, and the estimated total tank heat load varies from a low value of $110,000 \mathrm{Btu} / \mathrm{h}$ (Bander 1993) to as high as 132,400 Btu/h (Fryer, et al. 1995). Two homogeneous regions (Blaine et al 1996) corresponding to the bottom $4 \mathrm{ft}$ and top $2 \mathrm{ft}$ of the sludge, and with volumetric heat source terms of 6.3 and $1.5 \mathrm{Btu} / \mathrm{h}-\mathrm{ft}^{3}$, for a total heat load of $110,000 \mathrm{Btu} / \mathrm{h}$ and 7.9 and $1.9 \mathrm{Btu} / \mathrm{h}-\mathrm{ft}^{3}$ for a total heat load of $132,400 \mathrm{Btu} / \mathrm{h}$, were considered in the analysis. The waste parameters used in HUB analysis are given in Table 3-1.

The sludge in Tank $241-\mathrm{C}-106$ contains about $40 \%$ by weight of insoluble solids and the remaining liquid. However, when the sludge is retrieved by sluicing and transferred to Tank 241-AY-102, the insoluble particles in the slurry will settle to a lower weight fraction of solids. Bench scale settling experiments (Norton 1994a) using neutralized current acid waste(NCAW) simulant have shown that as the solids settled to about 12 to $15 \mathrm{wt} \%$, the sludge developed a large temperature gradient (Norton 1994b) indicating the presence of nonconvective medium (compacted sediment) where the heat transfer occurs by pure conduction rather than convection. This behavior of compacted sediment formation is also observed in recent bench scale tests (Brooks 1996) of Sludge Washing and Gravity Settling of Tank 241-C-106 Sludge. The final solids concentrations in the sediment after each sludge washing step increased from 12 $\mathrm{wt} \%$ after the first caustic leach to $22 \mathrm{wt} \%$ for the first water wash step. Based on these results and considering $40 \mathrm{wt} \%$ solids in the tank 241-C-106 sludge, a minimum fluffing factor of 2 is a reasonable but conservative assumption and, therefore, is used for estimating the potential peak sludge temperatures. More optimistic values are used for the analyses of section 3.6.

The distribution of heat-generating materials ${ }^{137} \mathrm{Cs}$ and ${ }^{90} \mathrm{Sr}$ in tank $241-\mathrm{C}-106$ sludge and their contribution to the heat load of transferred sludge in tank 241-AY-102 were studied 
HNF-SD-W320-ER-002, Rev. 0

parametrically assuming a range of $10 \%$ to $50 \%$ of the heat in the supernate of Tank 241-AY-102 due to the dissolved ${ }^{137} \mathrm{Cs}$.

\subsection{GOTH FLOOR CHANNEL MODEL DESCRIPTION AND RESULTS}

The GOTH 2-D three region model was used to evaluate the effectiveness of floor channel cooling following a $2.5 \mathrm{ft}$ of Tank 241-C-106 sludge transfer, and a fluffing factor of 2 after transfer to-Tank 241-AY-102 as described in (Sathyanarayana 1996b) and illustrated in Figure 3-1. Modifications were made to the sludge depth, sludge conductivity, floor flow rate, and dome ventilation flow inlet conditions. The floor flow rate was set at $155 \mathrm{cfm}$, which is the nominal estimated flow rate for the secondary annulus system without system or operations modifications $(0.5 \mathrm{in}$. W.G. vacuum in the annulus with no inlet blower and no 6 -inch drop line blockage). As noted in Figure 3-1, the total heat load in the Tank 241-C-106 transferred sludge was $28,150 \mathrm{Btu} / \mathrm{h}$, and the conductivity $0.4 \mathrm{Btu} / \mathrm{h}-\mathrm{ft}-\mathrm{R}$. The inlet dome ventilation was assumed to be provided by the Project W-030 ventilation system operating in the recycle mode with an average tank inflow temperature of $76^{\circ} \mathrm{F}$ at a relative humidity of $75 \%$.

The resultant steady-state sludge temperature distributions for the three radial regions are illustrated in Figure 3-2. The floor air temperature at the exit to the three radial regions is shown in Figure 3-3. Based on the predicted cooling channel air temperature raise and the potential for an air temperature increase, the floor channel cooling effectiveness was calculated to be $70 \%$. Other tank temperatures of interest are shown in Figure 3-4. It can be seen that although the dome gas and supernatant temperatures remain relatively low, the poor conduction within the sludge raises the maximum sludge temperature to a high level at this low air flow rate through the floor cooling channels. 
Figure 3-1. 2-D Nodalization for Middle Sludge and Floor Region--Approximate Maximum Distance Between Channels 4.5 feet.

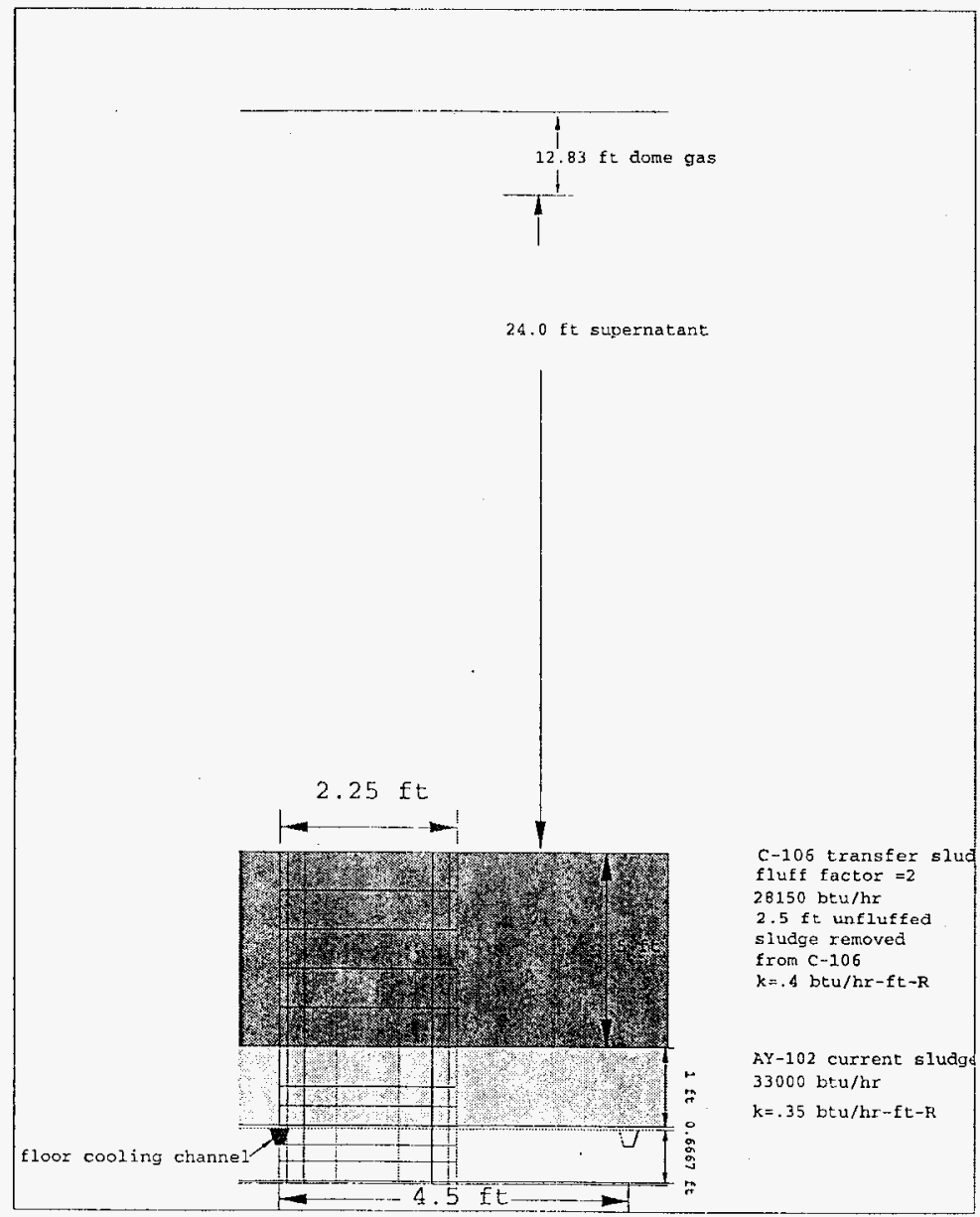


Figure 3-2. Tank 241-AY-102 Sludge Temperature Distribution for Models Three Radial Regions--155 cfm Floor Channel Flow, $2.5 \mathrm{ft}$ 241-C-106 Sludge Transfer.

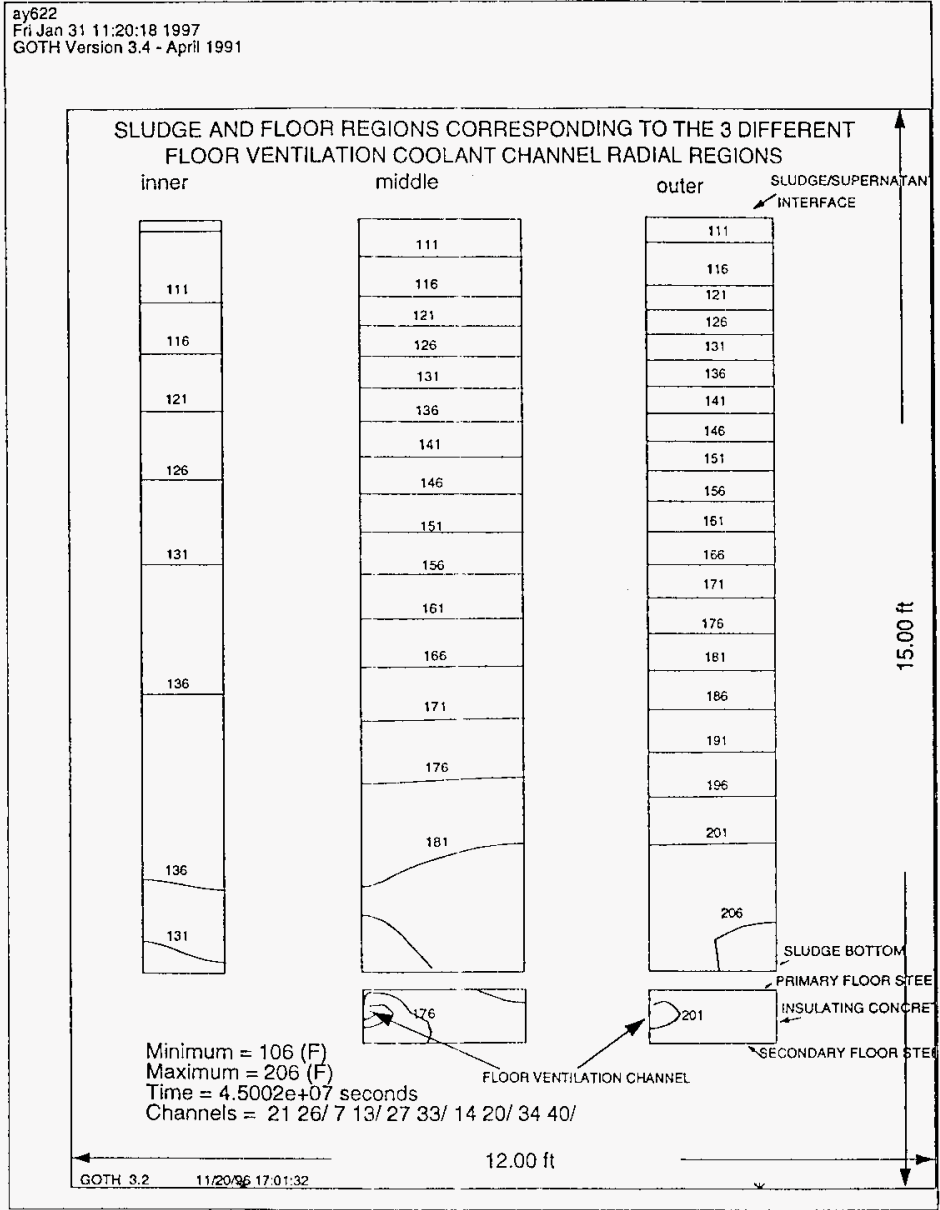


HNF-SD-W320-ER-002, Rev. 0

Figure 3-3. Tank 241-AY-102 Gas Temperatures at Floor Channel Exits Corresponding to Models 3 Radial Regions--155 cfm Floor Channel Flow, $2.5 \mathrm{ft}$ Tank 241-C-106 Sludge Transfer.

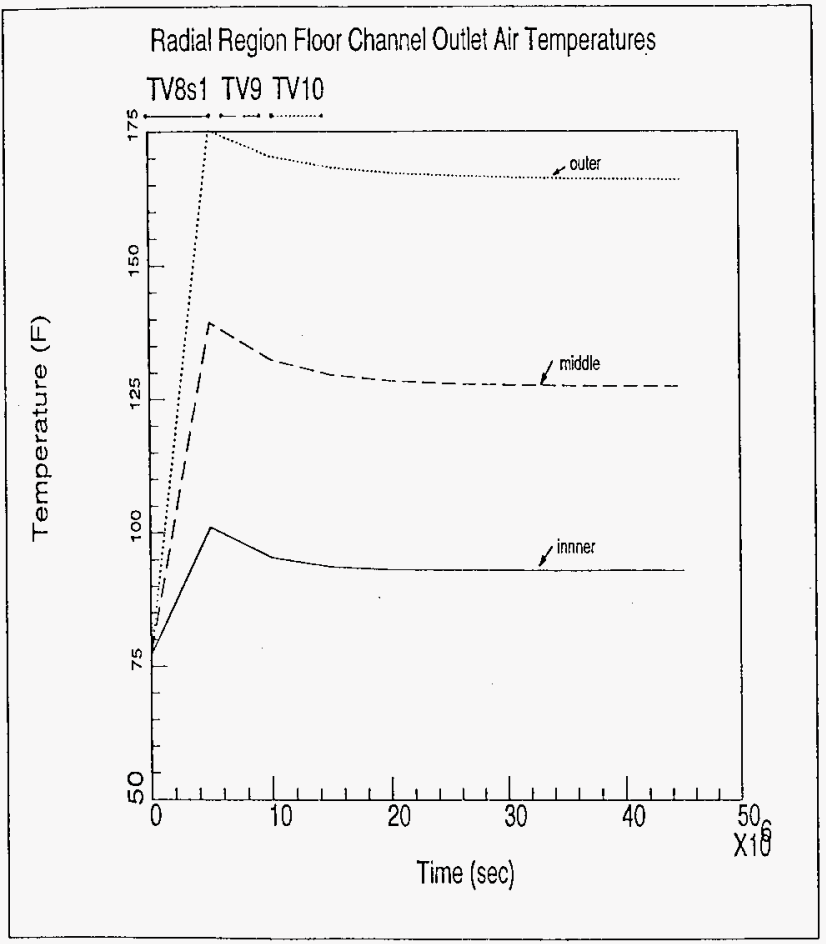


HNF-SD-W320-ER-002, Rev. 0

Figure 3-4. Tank 241-AY-102 Contents Temperatures for $155 \mathrm{cfm}$

Floor Channel and 2.5 ft Tank 241-C-106 Sludge Transfer.

ay622

Wed Feb 26 19:08:55 1997

GOTH Version 3.4-April 1991

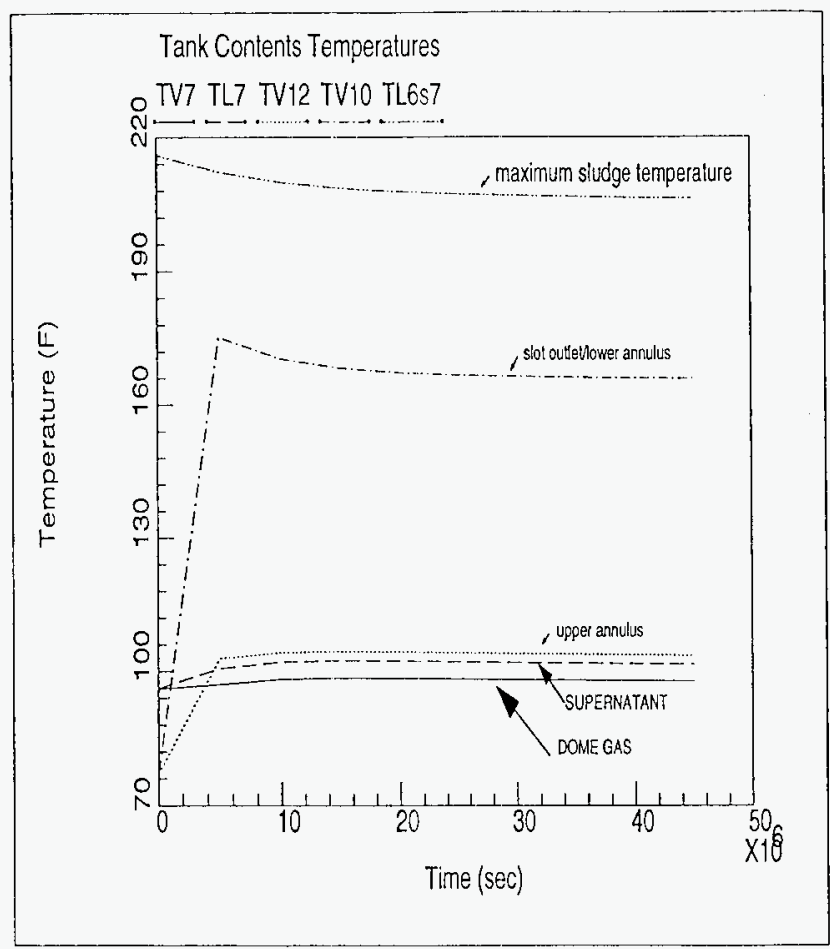




\subsection{HUB MODEL INPUT PARAMETERS}

The waste properties and the geometric parameters of the Tank 241-C-106 and Tank 241AY-102 are given in Table 3-1. The important thermal parameters of the analysis include the tank heat load and its distribution in the Tank 241-C-106 sludge; the growth of the sludge volume of the transferred Tank 241-C-106 sludge in Tank 241-AY-102; the heat load distribution between supernatant and sludge in Tank 241-AY-102 after transfer; the effective thermal conductivity of the settled sludge; and the floor and dome cooling effectiveness. These parameters are briefly discussed in this section. 


\subsubsection{Tank 241-C-106 Heat Load Distribution}

The heat load for Tank 241-C-106 was estimated to be 110,000 Btu/h using the measured temperature data through detailed thermal analyses (Bander 1993). The tank sludge temperature data suggests that the heat distribution is skewed toward the bottom with $89 \%$ of the heat in roughly $66 \%$ of the sludge (Crea 1996). After the 1994 Tank $241-\mathrm{C}-106$ process test, the heat load of the tank was reevaluated using GOTH, a two-phase thermal-hydraulic computer code, which mechanistically accounts for water evaporation. The heat load was estimated by the GOTH analyses to be $132,400 \mathrm{Btu} / \mathrm{h}$ (Fryer 1995). Also, 1996 grab samples from Tank 241-C106 were analyzed for radionuclides and a maximum tank heat load (Babad 1996) of 111,400 $\mathrm{Btu} / \mathrm{h}$ was established based on ${ }^{90} \mathrm{Sr}$ and ${ }^{137} \mathrm{Cs}$ content. The heat load distribution as given in Table 3-2 was also used in earlier analyses (Crea 1996).

Table 3-2. Tank 241-C-106 Waste Heat Load Distribution. (Ref. Crea 1996)

\begin{tabular}{|c|c|c|}
\hline & \multicolumn{2}{|c|}{ Volumetric heat source, $\mathrm{Btu} / \mathrm{h}-\mathrm{ft}^{3}$} \\
\hline $\begin{array}{c}\text { Tank Heat Load } \\
\text { Btu/h }\end{array}$ & $\begin{array}{l}\text { Region 1 } \\
\text { Top } 2 \mathrm{ft} \\
(4-6 \mathrm{ft})\end{array}$ & $\begin{array}{c}\text { Region } 2 \\
\text { Rest of the volume } \\
(0-4 \mathrm{ft})\end{array}$ \\
\hline 110,000 & 1.5 & 6.3 \\
\hline 132,400 & 1.9 & 7.9 \\
\hline
\end{tabular}

\subsubsection{Tank 241-AY-102 Fluffing Factor}

The sludge in Tank 241-C-106 consists of about 40 to $50 \mathrm{wt} \%$ of solids (Schreiber et al 1996). The insoluble solids in the sludge after mixing with Tank $241-\mathrm{AY}-102$ supernate are not expected to initially settle to its original concentration. Small scale settling tests using NCAW simulant, and the axial waste temperature (Norton 1994b) data during settling, shows that sludge with 10 to $15 \mathrm{wt} \%$ of solids establishes a fairly large temperature gradient, suggesting that the sludge has become non-convective. Bench scale enhanced sludge washing and gravity settling tests (Brooks 1997) conducted for tank 241-C-106 sludge shows higher weight percent of compacted solids as shown in Table 3-3. Also shown in the table are the screening test results of Lumetta, et al. (1996) who performed a similar experiment with 15 grams of tank 241-C-106 sludge. The bench scale test results show a higher weight percent of compacted solids than the screening test. The sludge layer associated with the bench scale test $(10-30 \mathrm{~cm})$ allowed further compaction due to increased weight on the lower layers of sludge compared to the screening tests.

The settling behavior of Tank 241-C-106 sludges with Tank 241-AY-102 supernate was also evaluated (Babad 1996), and the results show that sludge volume has increased after the solids have settled in the solid-liquid mixture. These results are given in Table 3-4, where in all 
HNF-SD-W320-ER-002, Rev. 0

Table 3-1. Tank 241-AY-102 and Tank 241-C-106 Waste Parameters.

\begin{tabular}{|c|c|c|}
\hline \multicolumn{2}{|c|}{ Parameter Description } & \multirow{2}{*}{\begin{tabular}{|c|} 
Assumed Values \\
812,000 gallons $(24.6 \mathrm{ft})$ \\
\end{tabular}} \\
\hline \multirow{5}{*}{$\begin{array}{l}\text { Tank 241-AY-102 Waste } \\
\text { Volume and Properties }\end{array}$} & Total waste & \\
\hline & Sludge & 32,000 gallons $(0.97 \mathrm{ft})$ \\
\hline & Supernate & 780,000 gallons $(23.6 \mathrm{ft})$ \\
\hline & Sludge density & $1.57 \mathrm{gm} / \mathrm{cm}^{3}$ \\
\hline & $\begin{array}{l}\text { Current sludge thermal } \\
\text { conductivity }\end{array}$ & $0.35 \mathrm{Btu} / \mathrm{h}-\mathrm{ft}^{3}$ \\
\hline \multirow{9}{*}{$\begin{array}{l}\text { Tank 241-C-106 Waste } \\
\text { Volume and Properties }\end{array}$} & Total waste & 219,000 gallons $(6.64 \mathrm{ft})$ \\
\hline & Sludge & 197,000 gallons $(5.97 \mathrm{ft})$ \\
\hline & Supernate & 22,000 gallons $(0.67 \mathrm{ft})$ \\
\hline & Sludge density & $1.55 \mathrm{gm} / \mathrm{cm}^{3}$ \\
\hline & Liquid density & $1.17 \mathrm{gm} / \mathrm{cm}^{3}$ \\
\hline & Insoluble solids density & $2.3 \mathrm{gm} / \mathrm{cm}^{3}$ \\
\hline & Wt $\%$ solids & $40 \%$ \\
\hline & Liquid thermal conductivity & $0.35 \mathrm{Btw} / \mathrm{h}-\mathrm{ft}^{3}$ \\
\hline & $\begin{array}{l}\text { Insoluble solid thermal } \\
\text { conductivity }\end{array}$ & $5 \mathrm{Btu} / \mathrm{h} \cdot \mathrm{ft}^{3}$ \\
\hline $\begin{array}{l}\text { Tank 241-AY-102 Heat } \\
\text { Load }\end{array}$ & Total & $\begin{array}{l}\text { Sludge: } 33,000 \mathrm{Btu} / \mathrm{h} \\
\text { Supernate: } 0 \mathrm{Btu} / \mathrm{h}\end{array}$ \\
\hline \multirow[t]{3}{*}{$\begin{array}{l}\text { Tank 241-C-106 Heat } \\
\text { Load }\end{array}$} & Total (Fryer estimate) & $\begin{array}{l}132,400 \mathrm{Btu} / \mathrm{h} \\
\text {-Region } 1(0-4 \mathrm{ft}): \quad 6.6 \mathrm{Btu} / \mathrm{h} / \mathrm{ft}^{3} \\
\text {-Region 2 }(4-6 \mathrm{ft}): \quad 1.9 \mathrm{Btu} / \mathrm{h} / \mathrm{ft}^{3}\end{array}$ \\
\hline & Total (Bander Estimate) & $\begin{array}{l}110,000 \mathrm{Btu} / \mathrm{h} \\
\text {-Region } 1(0-4 \mathrm{ft}): 5.5 \mathrm{Btu} / \mathrm{h} / \mathrm{ft}^{3} \\
\text {-Region 2 }(4-6 \mathrm{ft}): 1.5 \mathrm{Btu} / \mathrm{h} / \mathrm{ft}^{3}\end{array}$ \\
\hline & Insoluble solids & $0.143 \mathrm{Btu} / \mathrm{h} / \mathrm{lbm}$ \\
\hline \multirow{2}{*}{$\begin{array}{l}\text { Tank 241-AY-102 } \\
\text { Ventilation } \\
\text { Systems }\end{array}$} & $\begin{array}{l}\text { Primary ventilation: } \\
702-A \text { system }\end{array}$ & $\begin{array}{l}630 \mathrm{cfm} \text { at } 70 \% \text { and } 50 \% \text { relative } \\
\text { humidity }\end{array}$ \\
\hline & $\begin{array}{l}\text { Primary ventilation: } \\
\text { W-320 system }\end{array}$ & $\begin{array}{l}500 \mathrm{cfm} \text { at } 76^{\circ} \mathrm{F} \text { and } 75 \% \text { relative } \\
\text { humidity (Recirculation Mode) }\end{array}$ \\
\hline
\end{tabular}


four cases the volume of the sludge after mixing and settling has increased in volume compared to the volume of the original sludge in the starting material. Therefore, it is assumed that sluicing and resettling of the Tank 241-C-106 sludge in Tank 241-AY-102 will result in an increased volume, perhaps twice its original volume, or a fluffing factor of about 2 . However, the sludge in a full-scale tank should experience more compaction due to increased sludge height, reducing the final volume of settled sludge or the fluffing factor. A fluffing factor of 2 was used for the thermal evaluation of Tank 241-AY-102 to provide some margin of conservatism. This conservatism was reduced for the optimistic analyses of section 3.6.

Table 3-3. Tank 241-AY-102 Nonconvective Waste Fluff Factor.

(Brooks, et al. 1997/ Lumetta 1996)

\begin{tabular}{||l|c|c|}
\hline \multicolumn{1}{|c|}{ Sludge wash description } & Wt\% solids in final sediment & Fluffing factor \\
\hline \hline Caustic leach 1 & $14 / 13$ & $\sim 3.0$ \\
\hline Caustic leach 2 & $16 / 12$ & $\sim 3.0$ \\
\hline Water wash 1 & $22 / 13$ & $\sim 2.0$ \\
\hline Water wash 2 & $28 / 13$ & $<2.0$ \\
\hline Water wash 3 & $32 / 16$ & $<2.0$ \\
\hline
\end{tabular}

* Assuming tank 241-C-106 waste consists of $40 \mathrm{wt} \%$ solids.

Table 3-4. Tank 241-AY-102 Nonconvective Waste Fluffing Factor. (Babad 1996)

\begin{tabular}{|l|c|c|c|}
\hline & $\begin{array}{c}\text { Initial volume } \\
(\mathbf{m L})\end{array}$ & $\begin{array}{c}\text { Final volume } \\
\text { (mL) }\end{array}$ & $\begin{array}{c}\text { Fluffing } \\
\text { factor }\end{array}$ \\
\hline $6 \mathrm{C}-96-8$ & 9.0 & 18.0 & 2.0 \\
\hline $6 \mathrm{C}-96-14$ & 3.0 & 9.5 & $\sim 3.0$ \\
\hline $6 \mathrm{C}-96-8$ with tank 241-AY-102 & 10.0 & 43.0 & $\sim 4.0$ \\
\hline $6 \mathrm{C}-96-14$ with tank 241-AY-102 & 7.5 & 23.0 & $\sim 3.0$ \\
\hline
\end{tabular}

\subsubsection{Cs/Sr Distribution}

Recent tT 241-C-106 sludge sample analyses suggest that the major heat generating radionuclides of ${ }^{137} \mathrm{Cs}$ and ${ }^{90} \mathrm{Sr}$ are about equal proportion in the top portion of the sludge (Babad 1996). Strontium 90 produces about 1.4 times as much heat per curie as ${ }^{137} \mathrm{Cs}$. Also, the bench scale tests performed at Pacific Northwest National 
Laboratory (PNNL) (Lumetta 1996 and Brooks 1997) show that a major portion of ${ }^{137} \mathrm{Cs}$ will remain in solids. The leaching test results show a range from $38 \%{ }^{137} \mathrm{Cs}$ removal at low caustic to $60 \%$ at high caustic. Therefore, as much as $60 \%$ of the ${ }^{137} \mathrm{Cs}$ will remain in the sludge. However, in order to understand the effect of distributing the heat load between the sludge and supernate, parametric analyses were performed (section 3.4.3) assuming $10 \%$ and $50 \%$ of total heat in supernate and the remaining heat in sludge.

\subsubsection{Thermal Conductivity}

The thermal conductivity of the waste sludge is one of the parameters that determines the temperature distribution in the sludge. In general, the tank waste sludges contain liquid, solids and gas bubbles. The presence of a gas is neglected in the analysis. The effective thermal conductivity of the sludge is, therefore, computed using the individual thermal conductivities of liquid and solids. The insoluble solids are assumed to have a thermal conductivity of $5 \mathrm{Btu} / \mathrm{h}-\mathrm{ft} \mathrm{f}^{\circ} \mathrm{R}$ and that of interstitial liquid to have a thermal conductivity of $0.35 \mathrm{Btu} / \mathrm{h}-\mathrm{ft}^{\circ} \mathrm{R}$.

Three thermal conductivity models are presented below. They are shown graphically in Figure 3-5. The series conductivity was the most conservative and was used for the thermal analyses of Tank 241-AY-102.

\subsubsection{Parallel Conductivity Model}

If the heat conduction in the liquid and solid phases occurs in parallel, then the overall conductivity $\mathrm{K}_{\text {sludge }}$ is the weighted arithmetic mean of the thermal conductivities of liquid and solids.

$$
K_{\text {sludge }}=\left(\alpha_{p} * K_{s}+\alpha_{L} * K_{L}\right)
$$

\subsubsection{Series Conductivity Model}

On the other hand, if the heat conduction takes place in a series, with all of the heat flux passing through both solids and liquid in a series, then the overall conductivity of the sludge is the weighted harmonic mean of the individual thermal conductivities of the components.

$$
\left(\frac{1}{K_{\text {sludge }}}\right)=\left(\frac{\alpha_{s}}{K_{s}}+\frac{\alpha_{L}}{K_{L}}\right)
$$




\subsubsection{Maxwell's Equation}

An effective thermal conductivity of waste sludges composed of small solid spheres dispersed in liquid can also be calculated using Maxwell's equation (1892).

$$
K_{\text {sludge }}=K_{L}\left[\frac{2 K_{L}+K_{s}-2 \alpha_{s}\left(K_{L}-K_{s}\right)}{2 K_{L}+K_{s}+\alpha_{s}\left(K_{L}-K_{s}\right)}\right]
$$

where

$$
\begin{aligned}
& K_{\text {sludge }}=\text { Effective thermal conductivity of the sludge } \\
& K_{L} \quad=\text { Thermal conductivity of interstitial liquid } \\
& K_{s} \quad=\text { Thermal conductivity of insoluble solids } \\
& \alpha_{s} \quad=\text { Volume fraction of solids in the sludge } \\
& \alpha_{L} \quad=\text { Volume fraction of liquid in the sludge. }
\end{aligned}
$$

The variation of effective sludge thermal conductivity with respect to the solids volume fraction is compared in Figure 3-5. The sludge in Tank 241-C-106 contains less than a 20 -volume percent of solids and the remaining sludge is liquid. 
HNF-SD-W320-ER-002, Rev. 0

Figure 3-5. Effective Sludge Thermal Conductivity Variation With Solids Concentration.

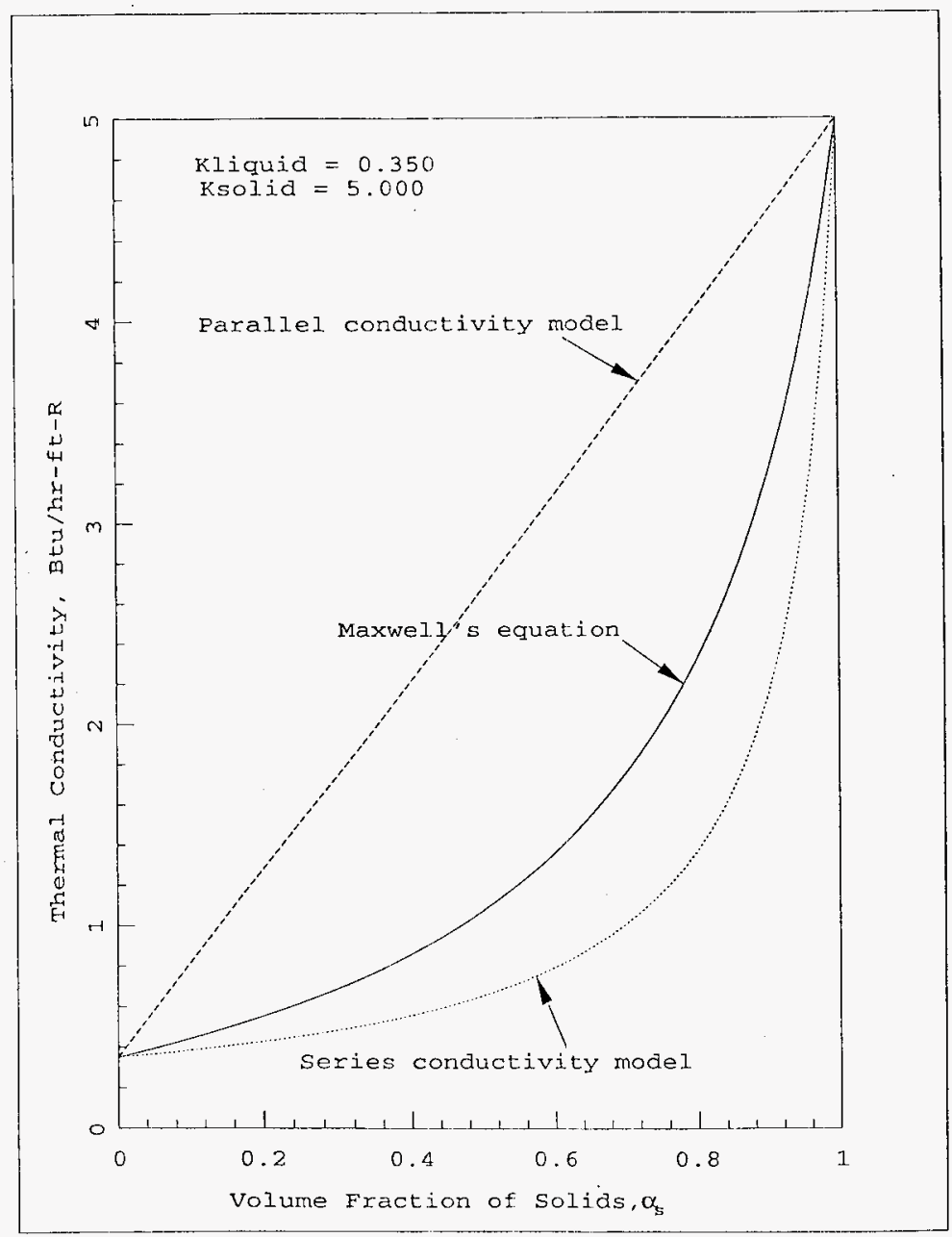




\subsection{TANK 241-AY-102 THERMAL ANALYSIS}

Tank 241-AY-102 is the receiver tank for the Tank 241-C-106 high heat sludge to be transferred by Project W-320 using a Waste Retrieval Sluicing System (WRSS). The WRSS mixes the sludge in Tank 241-C-106 with a sluice stream of supernate from Tank 241-AY-102 and pumps the slurry from Tank 241-C-106 to Tank 241-AY-102. The insoluble solids will settle from the slurry in the receiver tank, increasing the heat load as well as the sludge height. Increased heat load and sludge level will increase the peak sludge temperatures. However, the peak sludge temperatures are limited by tank design and safety considerations. The tank design consideration limits the peak sludge temperature to below $350^{\circ} \mathrm{F}$ (Boyless 1996), and safety considerations limit the peak sludge temperature to $30^{\circ} \mathrm{F}$ below the local saturation temperature (that is about $225^{\circ} \mathrm{F}$ at the sludge bottom and $195^{\circ} \mathrm{F}$ in the supernatant).

Tank 241-AY-102, as shown in Figure 3-6, is a double-shell tank which has a rated capacity of 980,000 gallons, and it is one of the four aging waste facility (AWF) tanks. Tank 241-AY-102 is an underground, carbon steel, radioactive waste tank encased in a concrete shell. The primary tank has an inner diameter of $75 \mathrm{ft}$ and a secondary tank with an inner diameter of $80 \mathrm{ft}$. The tank was designed for a vapor temperature of $220^{\circ} \mathrm{F}$ above $30 \mathrm{ft}$, a liquid temperature of $260^{\circ} \mathrm{F}$ at 4 to $30 \mathrm{ft}$, and a sludge temperature of $350^{\circ} \mathrm{F}$ at 0 to $4 \mathrm{ft}$. Currently, the tank contains 32,000 gallons $(\sim 1 \mathrm{ft})$ of heat generating sludge and 780,000 gallons of liquid waste. The heat load has been estimated to be $33,000 \mathrm{Btu} / \mathrm{h}$ (Sathyanarayana, et al. 1996b). The maximum sludge temperature at the bottom of the tank is about $92^{\circ} \mathrm{F}$. The tank waste is currently cooled by dome ventilation flow.

The AWF is currently served by the 702-A ventilation system, which supplies ambient air 10 the dome space of the AZ and AY tanks. Air flow for the annulus and floor channels in Tank $241-\mathrm{AY}-102$ is provided by an independent dedicated annulus ventilation system. The 702-A dome ventilation system is scheduled for upgrading prior to initiation of the Waste Retrieval Sluicing System (WRSS). 
Figure 3-6. Tank 241-AY-102 Aging Waste Double-Shell Tank.

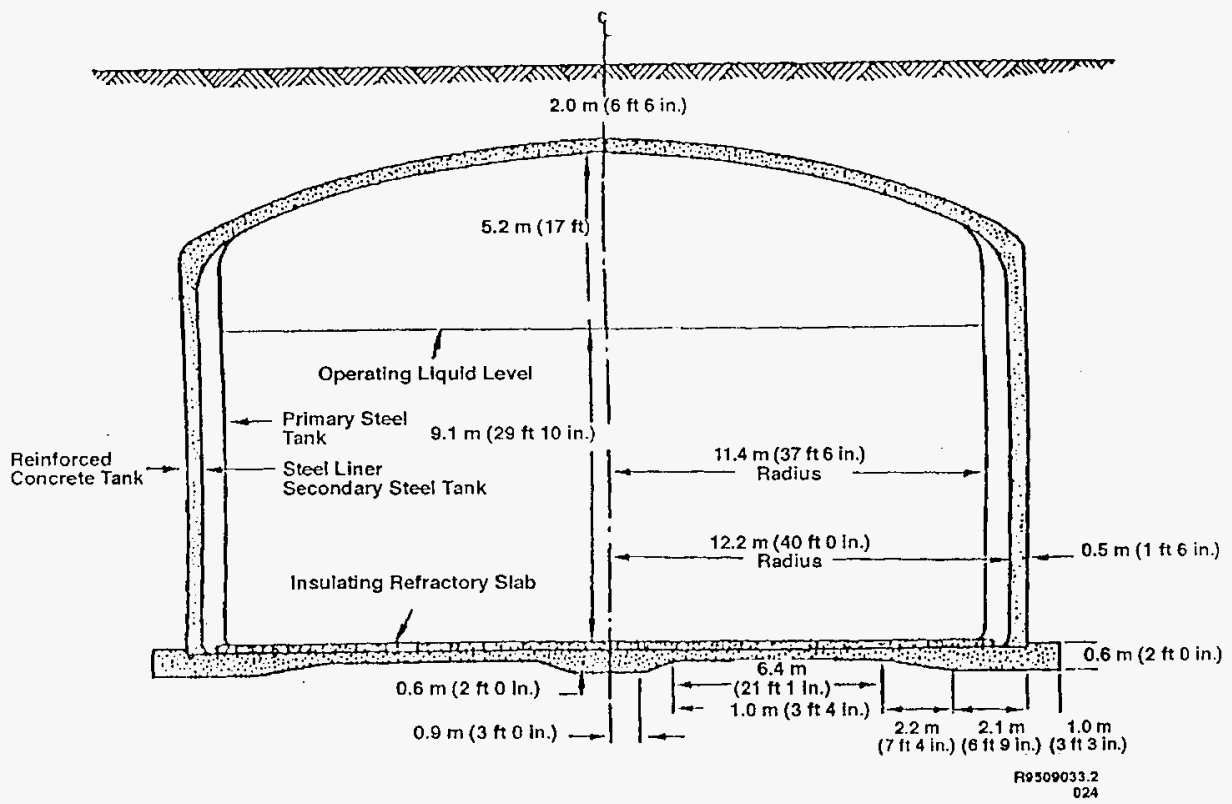




\subsubsection{Evaluation of Retrieval Options}

The Project $W-320$ intends to retrieve $100 \%$ of the sluicable sludge. However, the current heat removal capacity of Tank 241-AY-102 including secondary annulus/floor cooling system may not allow for complete retrieval given the constraint of keeping the maximum sludge temperature within the design and safety temperature limits. In order to operate Tank 241-AY102 safely and prevent conditions that can lead to a thermal (steam) bump, the Operational Safety Document (OSD) limits the peak sludge temperature to $30^{\circ} \mathrm{F}$ below the local saturation (boiling) temperature in the sludge. Also, to prevent any structural damage, the peak concrete temperatures are limited to below $350^{\circ} \mathrm{F}$ (Boyless 1996). Given the constraints on peak sludge temperature, a number of intermediate retrieval goals were evaluated to determine the maximum possible waste transfer to Tank 241-AY-102. Both floor/annulus system modifications and secondary ventilation system operational changes as discussed in Section 2 for supplying higher flows are considered. The intermediate retreival goals and secondary ventilation system configuration required to meet these goals are summarized in Table 3-5. A description of the retrieval options considered in the thermal analysis is given this section.

1. The first option evaluated was the minimal retrieval required to eliminate Tank 241-C106 water additions. This is estimated to be the transfer of the top $2 \mathrm{ft}$ of the Tank 241-C-106 sludge containing a heat load of about $16,800 \mathrm{Btu} / \mathrm{h}(4.9 \mathrm{KW})$ to 13,250 $\mathrm{Btu} / \mathrm{h}(3.9 \mathrm{KW})$. This will eliminate the continued water addition (Bander et al 1996) required for cooling the waste to keep temperatures within the allowable limits. This option will then resolve the safety issue and remove Tank 241-C-106 from the high heat Watch List in accordance with Public Law 101-510, Section 3137 (Wyden Amendment 1990).

2. The second case evaluated was the transfer of the top $4 \mathrm{ft}$ Tank 241-C-106 sludge containing a heat load of $72,800 \mathrm{Btu} / \mathrm{h}$. This amount of Tank 241-C-106 sludge transfer will eliminate both water additions and active ventilation. For the remaining heat load, passive ventilation is found (Bander et al 1996) to be sufficient to cool the tank.

3. The third option considered was the transfer of about $4.8 \mathrm{ft}$ of sludge having a heat load of $92,400 \mathrm{Btu} / \mathrm{h}$ from Tank 241-C-106. This will remove the tank from the High Heat Tank List. This will leave less than $40,000 \mathrm{Btu} / \mathrm{h}$ heat load in Tank 241-C-106.

4. Historically, the high heat limit has been $40,000 \mathrm{Btu} / \mathrm{hr}$ heat load. The Basis for Interim Operation (BIO) and subsequent Limiting Conditions for Operations (LCO) have set this limit to $26,000 \mathrm{Btu} / \mathrm{h}$. To meet this criteria, therefore, a fourth option was considered which requires the transfer of $106,400 \mathrm{Btu} / \mathrm{h}$ of heat load containing sludge from Tank 241-C-106 to Tank 241-AY-102. This requires the removal of about $5.2 \mathrm{ft}$ of sludge.

5. Finally, the most desirable option and final goal of Project W-320 is complete retrieval of Tank 241-C-106 waste into Tank 241-AY-102 and other double-shell tanks. 
The following floor/annulus system modifications were considered in the thermal evaluation of Tank 241-AY-102 for Project W-320 waste transfer:

1. Blocking the flow to the wall annulus

The air flow for the current secondary ventilation system splits between the wall annulus flow and the floor channels (section 2.2). Most of the flow goes to the wall annulus which provides very little cooling. Blockage of the wall annulus flow allows $100 \%$ of the secondary ventilation system flow to be delivered to the floor channels for maximum cooling.

2. Including an Inlet blower

The current system is equipped with an exhaust fan. Installation of an inlet blower would significantly enhance the performance of the system to provide higher flows to the tank floor cooling channels. The inlet portion of the system would however be required to operate at positive pressure.

3. Primary and secondary system chillers

Inlet air for both the primary and secondary ventilation systems are at ambient air conditions. The addition of chillers to either one or both of theses systems would increase temperature difference between the tank waste and ventilation systems, increasing their heat removal capacity. It would also eliminate the seasonal variation in cooling.

The following secondary ventilation system operational modifications were considered in the thermal evaluation of Tank 241-AY-102:

1. High annulus vacuum

The primary ventilation (tank dome) system is currently required to operate at higher vacuum than the secondary ventilation system. This limits the annulus vacuum to about 0.5 inches water gauge. Project W-030 may potentially eliminate any possible cross connections making it possible for the annulus system to operate at a vacuum higher than the primary. This would increase the pressure drop in the secondary annulus system and substantially increase the flow.

2. Inlet system positive pressure

The current secondary ventilation system operates at a vacuum from the inlet filters to the exhaust fan. The addition of an inlet blower would require the inlet portion of the system to operate at positive pressure. 
Table 3-5. Summary of Retrieval Goals

\begin{tabular}{|c|c|c|c|c|c|c|c|c|}
\hline \multicolumn{3}{|c|}{ C-106 Retrieval Goals } & \multicolumn{6}{|c|}{ AY-102 Ventilation Configuration Options } \\
\hline $\begin{array}{c}\text { Case } \\
\neq !\end{array}$ & $\begin{array}{c}\text { Retrieval Case } \\
\text { Description } \\
\text { (depth/heat load) }\end{array}$ & Comment & $\begin{array}{l}\text { Chilled Air } \\
40^{\circ} \mathrm{F}\end{array}$ & $\begin{array}{l}\text { Minimum } \\
\text { Slot Flow } \\
\text { (clm) }\end{array}$ & $\begin{array}{l}\text { Annulus } \\
\text { Wall Flow } \\
\text { Configuration' }\end{array}$ & $\begin{array}{l}\text { Tolal } \\
\text { Secondary } \\
\text { System Flow } \\
\text { (cfri) }\end{array}$ & $\begin{array}{c}\text { Annulus } \\
\text { Gauge } \\
\text { Pressure } \\
\text { (Inch } \mathrm{H}_{2} \mathrm{O} \text { ) } \\
\end{array}$ & $\begin{array}{l}\text { Inlet Blower } \\
\text { Discharge } \\
\text { Gauge } \\
\text { Pressure } \\
\text { (Inch } \mathrm{H}_{2} \mathrm{O} \text { ) }\end{array}$ \\
\hline 1 & $\begin{array}{c}2 \mathrm{ft} \\
13,250 \mathrm{Btu} / \mathrm{hr}\end{array}$ & $\begin{array}{c}\text { Eliminates } \\
\text { waler } \\
\text { additions }\end{array}$ & none & $0 \mathrm{cfm}$ & unblocked & $0 \mathrm{cfm}$ & -0.5 & none \\
\hline \multirow{9}{*}{2} & \multirow{9}{*}{$\begin{array}{c}4 \mathrm{ft} \\
72,800 \mathrm{Btu} / \mathrm{hr}\end{array}$} & \multirow{9}{*}{$\begin{array}{l}\text { Eliminates } \\
\text { active } \\
\text { ventilation }\end{array}$} & \multirow{4}{*}{ none } & \multirow{4}{*}{$1000 \mathrm{cfm}$} & \multirow{2}{*}{ unblocked } & \multirow{2}{*}{$4800 \mathrm{cfm}$} & -0.5 & 17 \\
\hline & & & & & & & -12 & 5.5 \\
\hline & & & & & \multirow{2}{*}{ blocked } & \multirow{2}{*}{$1000 \mathrm{cfm}$} & -0.5 & 6.0 \\
\hline & & & & & & & -6.5 & none \\
\hline & & & \multirow{4}{*}{ Secondary } & \multirow{4}{*}{$750 \mathrm{cfm}$} & \multirow{2}{*}{ unblocked } & \multirow{2}{*}{$3600 \mathrm{cfm}$} & -0.5 & 9.5 \\
\hline & & & & & & & -10 & none \\
\hline & & & & & \multirow{2}{*}{ blocked } & \multirow{2}{*}{$750 \mathrm{cfm}$} & -0.5 & 3.3 \\
\hline & & & & & & & -3.8 & none \\
\hline & & & Primary & $850 \mathrm{~cm}$ & unblocked & $4100 \mathrm{cfm}$ & -12 & none \\
\hline \multirow{5}{*}{3} & \multirow{5}{*}{$\begin{array}{c}4.8 \mathrm{ft} \\
92,000 \mathrm{Btu} / \mathrm{hr}\end{array}$} & \multirow{5}{*}{$\begin{array}{l}\text { Eliminates } \\
\text { high heat } \\
\text { designation }\end{array}$} & \multirow{2}{*}{ none: } & \multirow{2}{*}{$2000 \mathrm{cfm}$} & \multirow{2}{*}{ blocked } & \multirow{2}{*}{$2000 \mathrm{cfm}$} & -0.5 & 25 \\
\hline & & & & & & & -12 & 13 \\
\hline & & & \multirow{2}{*}{ Secondary } & \multirow{2}{*}{$1400 \mathrm{cfm}$} & \multirow{2}{*}{ blocked } & \multirow{2}{*}{$1400 \mathrm{cfm}$} & -0.5 & 13 \\
\hline & & & & & & & -12 & 1.0 \\
\hline & & & $\begin{array}{l}\text { Primary \& } \\
\text { Secondary }\end{array}$ & $1200 \mathrm{cfm}$ & blocked & $1200 \mathrm{cfm}$ & -9.5 & none \\
\hline \multirow{4}{*}{4} & \multirow{4}{*}{$\begin{array}{c}5.2 \mathrm{ft} \\
106,000 \mathrm{Btu} / \mathrm{hr}\end{array}$} & \multirow{4}{*}{$\begin{array}{l}\text { Eliminates } \\
\text { temperature } \\
\text { monitoring }\end{array}$} & \multirow{2}{*}{ none } & \multirow{2}{*}{$3000 \mathrm{cfm}$} & & & -0.5 & 58 \\
\hline & & & & & blocked & $3000 \mathrm{cfm}$ & -12 & 47 \\
\hline & & & & & & $2200 \mathrm{~cm}$ & -0.5 & 31 \\
\hline & & & Secondary & $2200 \mathrm{ctm}$ & blocked & $2200 \mathrm{ctm}$ & -12 & 19 \\
\hline & & Complete & & & & & -0.5 & 40 \\
\hline $5^{1}$ & $132,000 \mathrm{Blu} / \mathrm{hr}$ & retrieval & Secondary & $2500 \mathrm{ctm}$ & blocked & $2500 \mathrm{crm}$ & -12 & 29 \\
\hline
\end{tabular}

1. Assuming a fluffing factor of 1.5 . 
The HUB computer model described in section 3.3 was used to evaluate the thermal performance of Tank 241-AY-102 for Project W-320 retrieval. The secondary ventilation system performance evaluated in section 2.4 provided the flow boundary conditions for the HUB model. The evaluation of each of the intermediate retrieval goals is provided in the following sections and summarized in Table 3-5.

\subsubsection{Case 1 - 2 ft Sludge Transfer}

The temperature distributions in the combined sludge in Tank 241-AY-102 are shown in Figure 3-7 for the transfer of the top $2 \mathrm{ft}$ of Tank 241-C-106 sludge. The results are shown both for high and low heat load values. In each case, the calculated temperature distribution in the sludge is shown for no slot cooling flow and normal secondary flow which provides about 150 cfm slot cooling flow. The primary ventilation system (W-030) was assumed to provide $500 \mathrm{cfm}$ total flow with an effective inlet flow condition of $76^{\circ} \mathrm{F}$ and $75 \%$ relative humidity. For the case of $150 \mathrm{cfm}$ cooling slot flow, an effectiveness parameter of 0.7 has been used. Also, it is assumed that the resettled Tank 241-C-106 sludge in Tank 241-AY-102 will have its volume doubled compared to its original volume (i.e., a fluff factor of 2). Under these conditions, the peak sludge temperatures are well below the Operating Safety Requirements (OSR) limit even with no cooling at the tank bottom.

\subsubsection{Case 2 - $4 \mathrm{ft}$ Sludge Transfer}

Figure 3-8 shows the waste temperature distribution for the settled sludge in Tank 241AY -102 with the transfer of about $4 \mathrm{ft}$ of Tank $241-\mathrm{C}-106$ sludge having a heat load of 72,800 $\mathrm{Btw} / \mathrm{h}$. This case requires a primary ventilation flow of $500 \mathrm{cfm}$ with an effective air inlet temperature of $76^{\circ} \mathrm{F}$ and $75 \%$ relative humidity. The fluff factor of the transferred sludge from Tank 241-C-106 is assumed to be 2 and the effectiveness of slot cooling flow is 0.35 . The cooling effectiveness for flows of more than $2,500 \mathrm{cfm}$ has been estimated (Sathyanarayana $1996 \mathrm{~b}$ ) to be 0.35 and in this report it is shown that the effectiveness can increase up to 0.7 for low flows of about $150 \mathrm{cfm}$. Figure 3-8 shows that the peak sludge temperatures will stay within safety limits if: (1) the tank bottom slot cooling flow is increased to $1000 \mathrm{cfm}$, or (2) the slot flow is $750 \mathrm{cfm}$ and the inlet temperature is chilled to $40^{\circ} \mathrm{F}$ (chilled air), or (3) the slot flow is $850 \mathrm{cfm}$ and $500 \mathrm{cfm}$ primary ventilation flow with an inlet temperature of $40^{\circ} \mathrm{F}$ (chilled primary air). The estimate of tank bottom slot cooling flows are conservative because of assumed low cooling effectiveness, and conservative fluff factor.

\subsubsection{Case 3 - 4.8 ft Sludge Transfer}

For the 3rd retrieval goal of leaving only 40,000 Btu/h in Tank $241-\mathrm{C}-106$ and transferring the rest of the sludge to Tank 241-AY-102, the temperature distribution of the settled sludge in Tank 241-AY-102 is shown in Figure 3-9. This calculation is performed using a fluff factor of 2 and the effectiveness of tank floor cooling channels as 0.35 . The results show that the peak sludge temperatures can be maintained within the safety limits by increasing the floor cooling channel flow. In this case, $2,000 \mathrm{cfm}$ floor cooling normal flow is required. This flow requirement can be reduced by using a chilled air either for floor cooling, dome cooling, or both. 
As shown in Figure 3-9, primary flow of $500 \mathrm{CFM}$ at $70 \mathrm{~F}$ and a chilled floor cooling flow of $1,400 \mathrm{cfm}$ is required for this option to keep peak sludge temperatures to within safety limits. This flow can further be reduced to $1,200 \mathrm{cfm}$ if both the primary and the tank floor cooling flows enter the tank at $40^{\circ} \mathrm{F}$.

\subsubsection{Case 4 - $5.2 \mathrm{ft}$ Sludge Transfer}

The fourth retrieval goal of limiting the Tank 241-C-106 sludge heat load to $26,000 \mathrm{Btu} / \mathrm{h}$ requires the transfer of about $5.2 \mathrm{ft}$ of sludge with a heat load of $106,400 \mathrm{Btu} / \mathrm{h}$. Figure 3-10 shows the results of thermal analysis for the combined sludge temperature distribution in Tank 241-AY-102. The analysis was performed assuming that the $\mathrm{W}-030$ primary ventilation system can provide $500 \mathrm{cfm}$ flow at an effective inlet temperature of $76^{\circ} \mathrm{F}$ and $75 \%$ relative humidity. Two cases were considered for the secondary annulus flow. The first was nominal inlet temperature of $70^{\circ} \mathrm{F}$ and the second assumed $40^{\circ} \mathrm{F}$ chilled air. In both cases, substantially higher floor cooling channel flow was required. Also, it is assumed that the fluff factor for the transferred sludge and the cooling channel effectiveness are 2 and 0.35 , respectively. The results show that Tank 241-AY-102 will operate within the safety limits if it is supplied with 3,000 cfm flow at $70^{\circ} \mathrm{F}$ or $2,200 \mathrm{cfm}$ flow at $40^{\circ} \mathrm{F}$ to the tank bottom floor cooling slots. 
Figure 3-7. Temperature Distribution of the Combined Sludge in Tank 241-AY-102 using W-030 Primary Ventilation System with 0 and 150 CFM Floor Cooling Channel Flow.

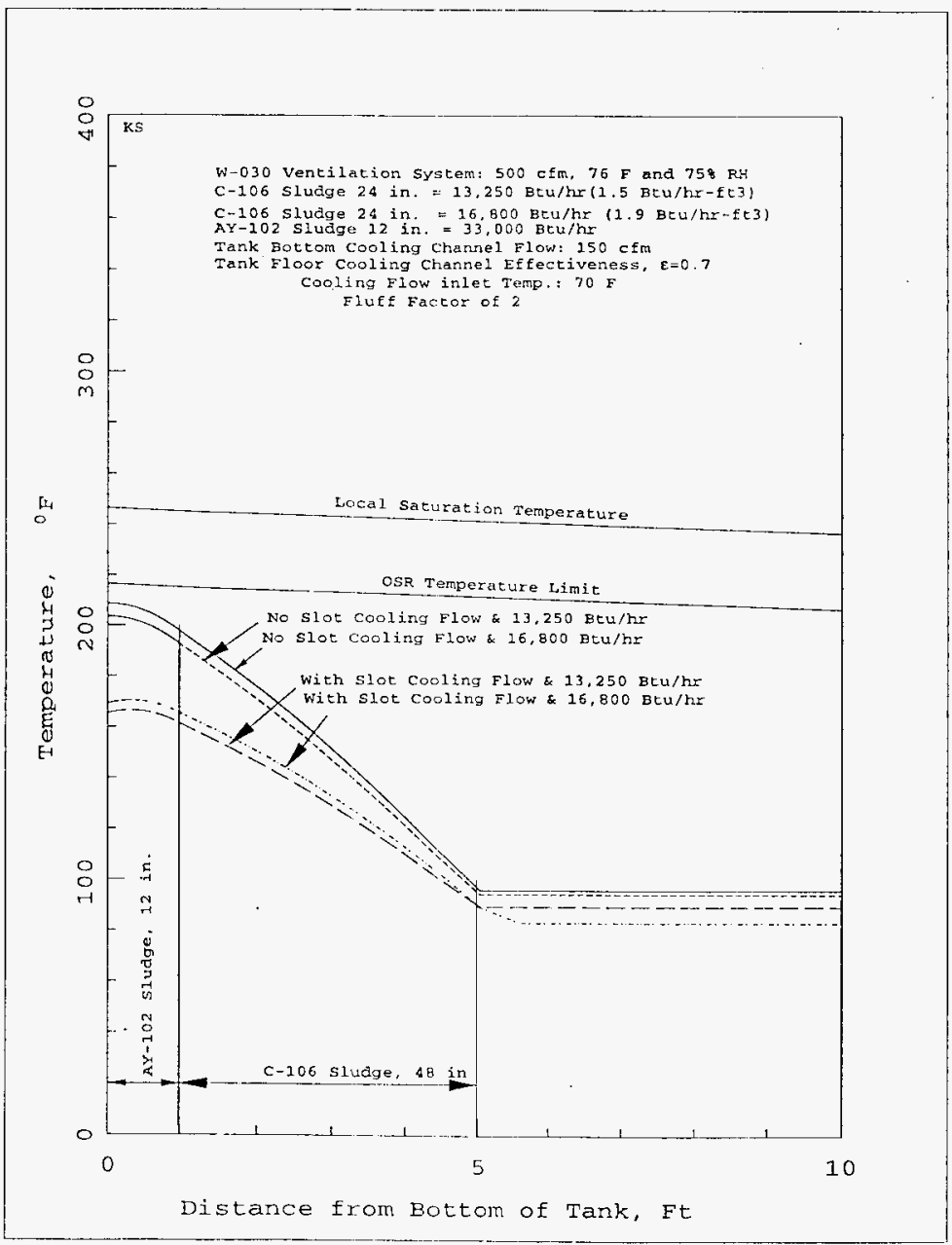


Figure 3-8. Temperature Distribution of the Combined Sludge in Tank 241-AY-102 using W-030 Primary Ventilation System with a) 1000 CFM at $70 \mathrm{~F}$ b) $750 \mathrm{CFM}$ at $40 \mathrm{~F}$ and 850 CFM at $70 \mathrm{~F}$ floor cooling Channel Flow.

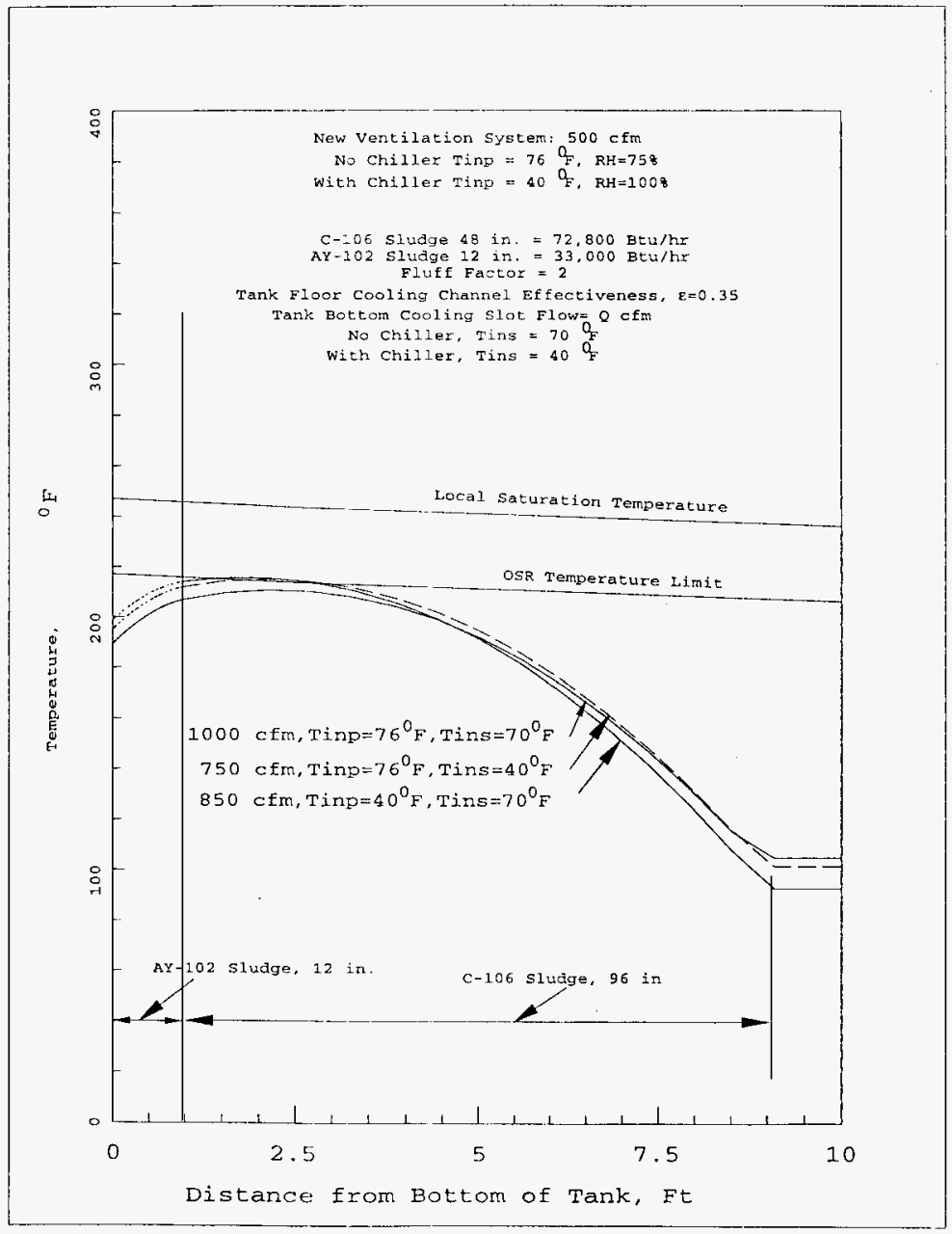


Figure 3-9. Temperature Distribution of the Combined Sludge in Tank 241-AY-102 using W-030 Primary Ventilation System with a) 2000 CFM at $70 \mathrm{~F}$ b) $1400 \mathrm{CFM}$ at $40 \mathrm{~F}$ and 1200 CFM at 40 F Floor Cooling Channel Flow.

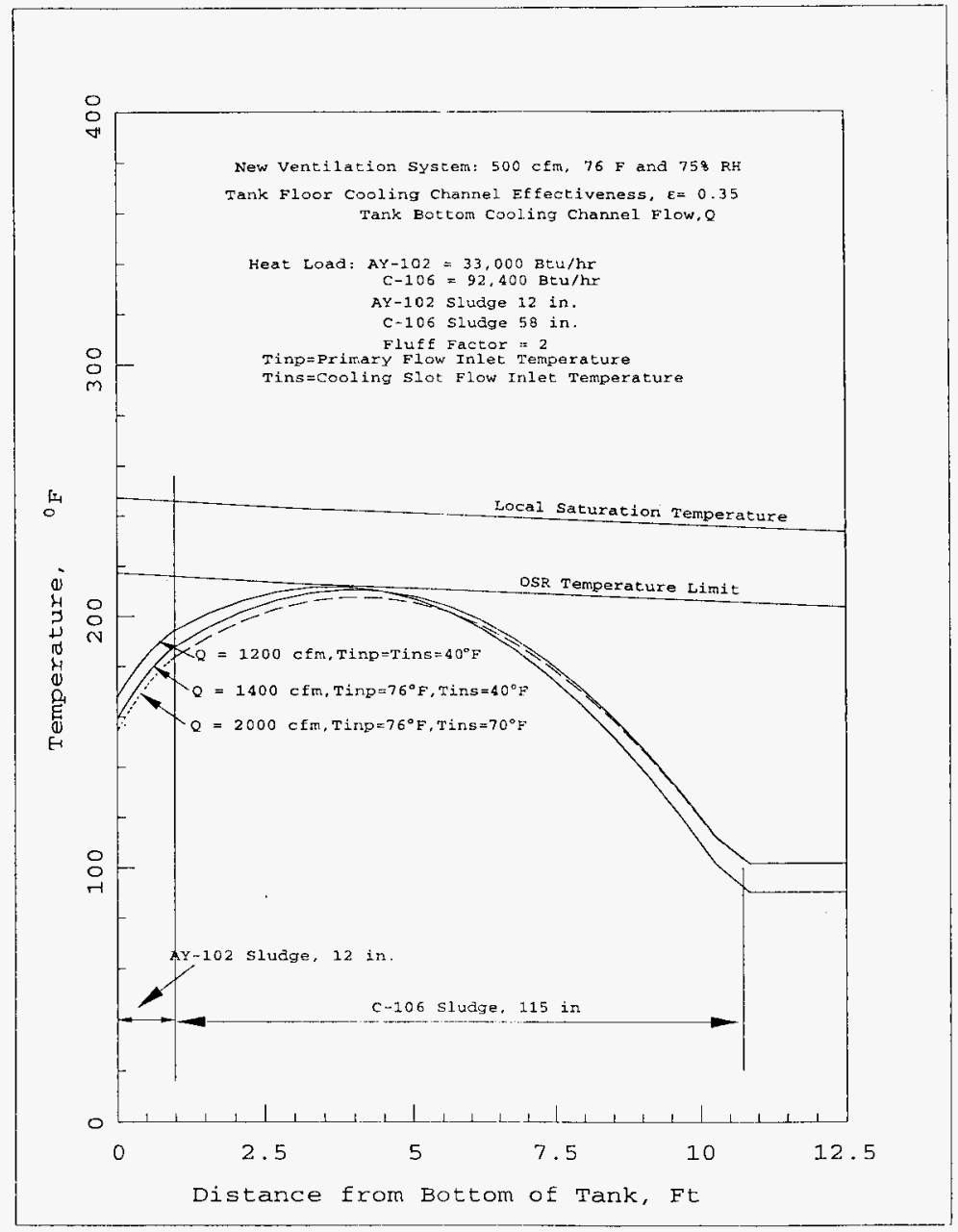


Figure 3-10. Temperature Distribution of the Combined Sludge in Tank 241-AY-102 using W-030 Primary Ventilation System with a) $3000 \mathrm{CFM}$ at $70 \mathrm{~F}$ and b) $2200 \mathrm{CFM}$ at $40 \mathrm{~F}$ Floor Cooling Channel Flow.

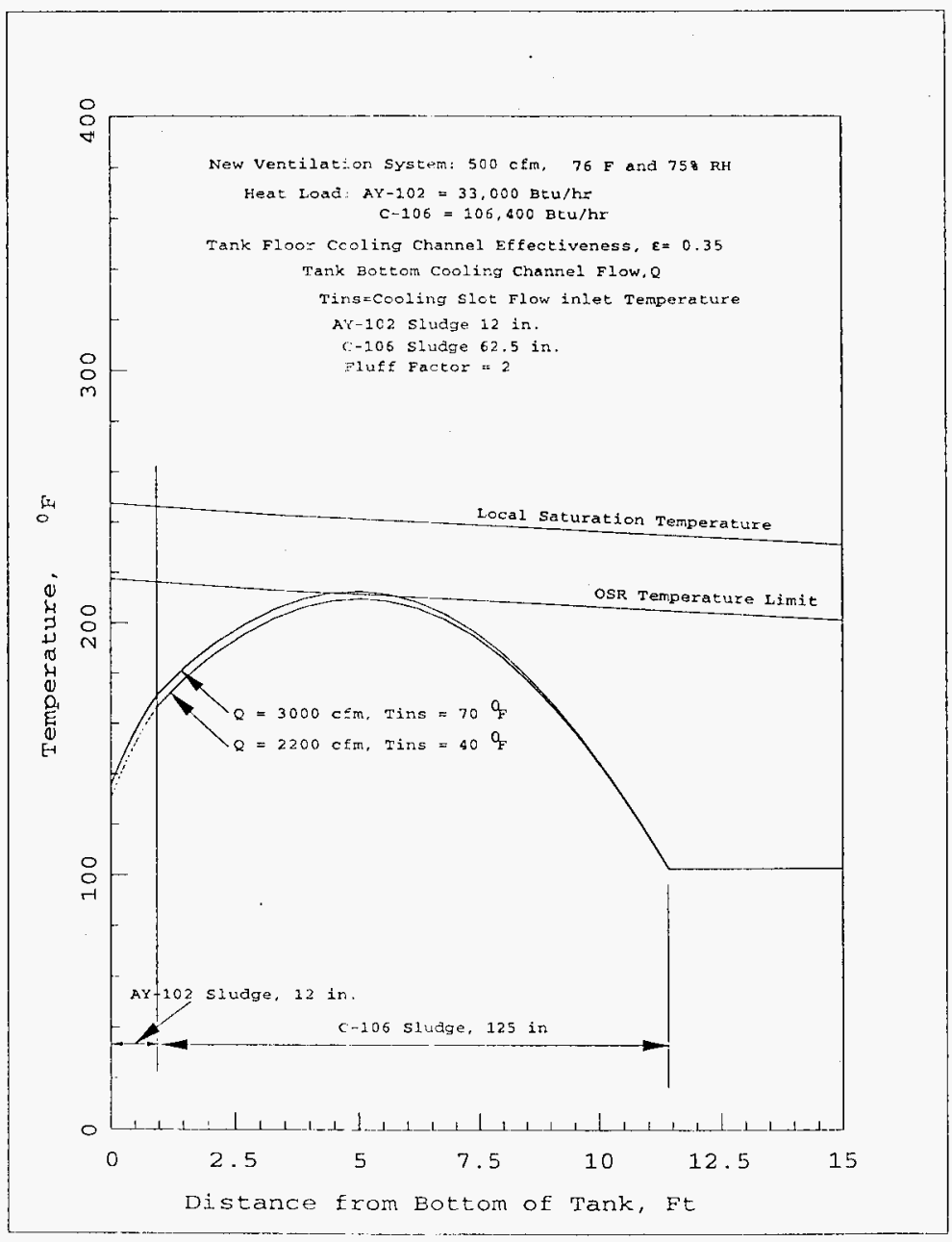




\subsubsection{Case 5 - Complete Sludge Retrieval}

Finally, the primary retrieval goal is to transfer all the waste from Tank 241-C-106 to Tank 241-AY-102. The estimated maximum heat load of the waste in Tank 241-C-106 is 132,400 $\mathrm{Btu} / \mathrm{h}$ and its height is about $6 \mathrm{ft}$. Figure 3-11 shows the temperature distribution in the combined sludge assuming that the transferred sludge in Tank 241-AY-102 will settle to a fluff factor of 2, or to a minimum 1.5 (MacLean 1997). The thermal analysis was performed to estimate the required tank floor cooling channel flows. The cooling slot flow is assumed to be supplied at an inlet temperature of $40^{\circ} \mathrm{F}$ and the tank floor cooling channels will have an effectiveness of 0.35 . If the sludge fluff factor remains as 2 , then $3,000 \mathrm{CFM}$ of chilled cooling slot flow will barely keep the peak sludge temperature below local boiling point. However, if the fluff factor reduces to 1.5 , then with 2,500 CFM chilled flow will keep the peak sludge temperature below OSR temperature limits.

\subsubsection{Sludge Fluffing Factor Parametric Analyses}

The heat generation in the Tank 241-C-106 sludge has been established (Bander 1993, Babad 1996) to be non-uniform. Consequently, the heat generating insoluble solids are distributed non-uniformly. Assuming the heat generation per unit mass of insoluble solids remains the same throughout the sludge, the volume fraction of solids in the sludge varies from the top to the bottom of the sludge based on the heat generation rate. Recent tests related to chemical and chemically related issues associated with sluicing Tank 241-C-106 waste to Tank 24l-AY-102 (Babad 1996) have shown that the potential fluffing factor of the transferred sludge will likely be a minimum of 2 to as large as 4 . Also, the bench-scale enhanced sludge washing and gravity settling of tank $241-\mathrm{C}-106$ sludge show that the solids concentration in the final compacted sludge varies from $14 \mathrm{wt} \%$ for the first caustic leach to a maximum of $32 \mathrm{wt} \%$ after two caustic leaches and three water washes. Currently, Tank 241-C-106 sludge contains about $40 \mathrm{wt} \%$ of insoluble solids and therefore, there is the potential that the compacted Tank 241-C106 sludge in Tank 241-AY-102 may result in a fluff factor of less than 2 . In order to understand ${ }^{\circ}$ the effect of the fluff factor of the transferred Tank 241-C-106 sludge in Tank 241-AY-102, parametric studies were performed for the second option.

The results of thermal analysis for the combined sludge in Tank 241-AY-102 are shown in Figure 3-12. A fluff factor of 2 requires $1,000 \mathrm{cfm}$ tank floor cooling slot flow to keep the sludge below the OSR temperature limit. On the other hand, if the fluff factor is 1 , then less than $200 \mathrm{cfm}$ cooling flow is sufficient. However, if the fluff factor is three, then $1,800 \mathrm{cfm}$ flow will be required.

The fluff factor of the transferred Tank 241-C-106 sludge settled in Tank 241-AY-102 determines the conduction length for heat transfer which exerts a large influence on the steady state sludge temperature distribution. 
Figure 3-11. Temperature Distribution of the Combined Sludge in Tank 241-AY-102 using W-030 Primary Ventilation System with a) 3000 CFM and b) 2500 CFM at 40 F Floor Cooling Channel Flow.

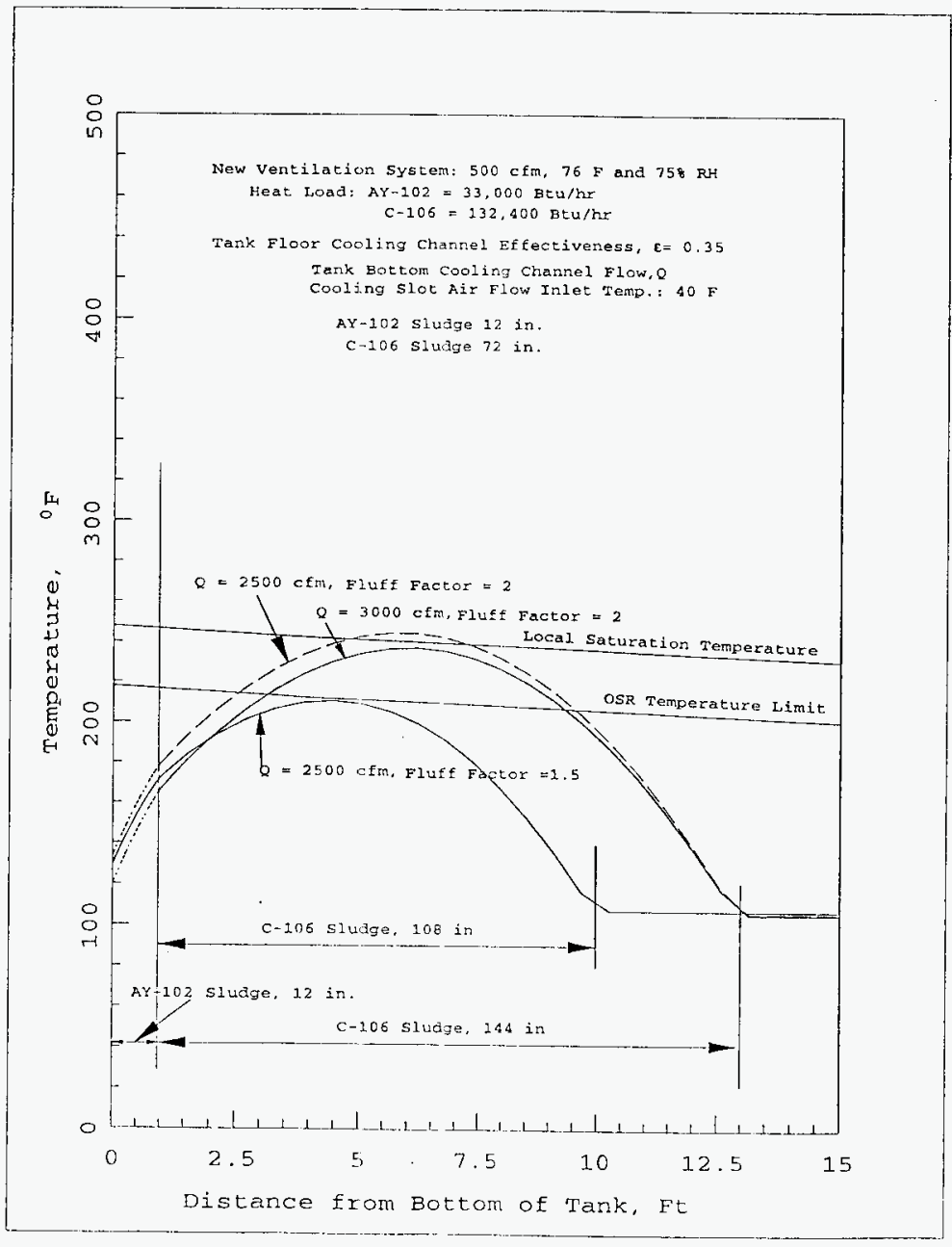


Figure 3-12. Temperature Distribution of the Combined Sludge in Tank 241-AY-102 using W-030 Primary Ventilation System with a) 1800 CFM for Fluff Factor of 3, b) 1000 CFM for Fluff Factor of 2 and b) 200 CFM for Fluff Factor of 1 of Floor Cooling Channel Flow at $70 \mathrm{~F}$.

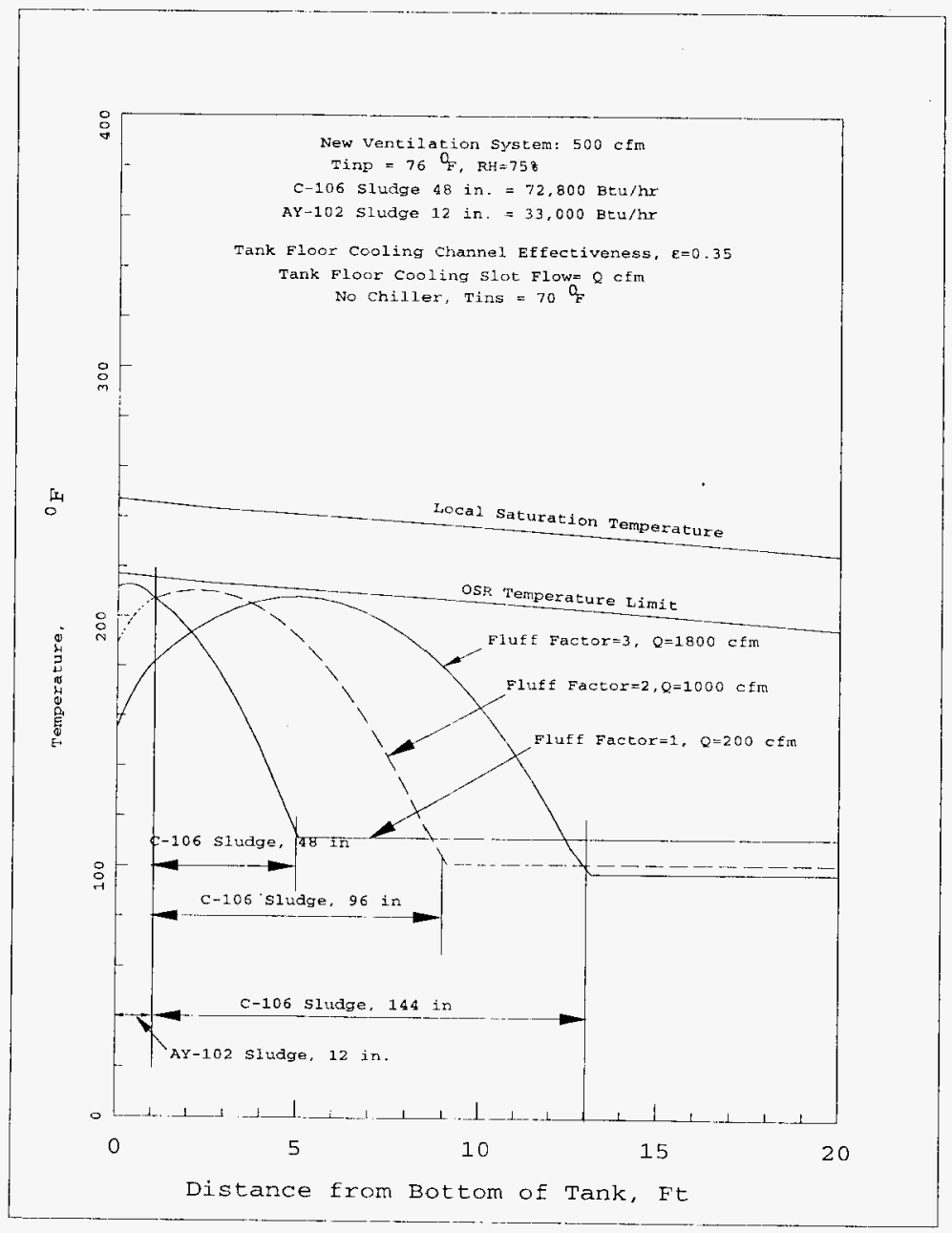




\subsection{3 ${ }^{137} \mathrm{Cs} /{ }^{90} \mathrm{Sr}$ Distribution Parmetric Analyses}

Figure 3-13 shows the effect of the heat generation distribution between sludge and supernate on the sludge peak temperature distribution. The analysis was performed for a total heat load of 40,100 Btu/h of Tank 241-C-106 sludge transfer to Tank 241-AY-102. Under normal operation of Tank 241-AY-102 the peak sludge temperature will be reduced by about 20 of if $50 \%$ of the heat is in supernate. On the other hand if only $10 \%$ of the heat is in supernate, the effect is negligible.

\subsection{EVALUATION OF PHASE 1 SLUICING OF TANK 241-C-106}

The results of the thermal analysis of the receiver Tank 241-AY-102 discussed in the previous Section 3.4.1, suggests that the first retrieval goal of transferring about $2 \mathrm{ft}$ of Tank 241-C-106 sludge can be accomplished even without operating the secondary ventilation system. The transfer of $2 \mathrm{ft}(\sim 66,000$ gallons $)$ of Tank 241-C-106 sludge to Tank 241-AY-102 will eliminate the need to add water to Tank 241-C-106. This will be the first phase of Project W-320 retrieval.

Process control of the mass transfer is required to assure that Tank 241-AY-102 steady state temperatures will not exceed the temperature limits. Operation of the secondary ventilation system will provide a margin of safety for the phase 1 waste transfer. Analyses were performed to quantify this safety margin and access the uncertainty of Tank 241-C-106 heat load and the primary system flow in achieving the phase 1 goals of $2 \mathrm{ft}$ waste retricval.

\subsubsection{Margin of Safety}

As shown in Figure 3-14, with the currently assumed heat generation rate, settled sludge conditions, and the primary and secondary ventilation flow conditions, the transfer of $2 \mathrm{ft}$ ( $\sim 66,000$ gallons) of sludge to Tank $241-A Y-102$ would not exceed the temperature limits set by the safety analysis. Under these operating conditions of Tank 241-AY-102 and safety limits, using the heat generation rates corresponding to a total tank heat load of $110,000 \mathrm{Btu} / \mathrm{h}$, the maximum possible sludge transfer was estimated. Figure 3-14 shows the sludge temperature distributions for the transfer of 32 in. (88,000 gallons) to 36 in $(\sim 100,000$ gallons) of Tank 241-C-106 sludge to Tank 241-AY-102. It can be seen that even if the fluff factor of the transferred Tank 241-C-106 sludge is two, 94,000 gallons (34 in.) can be transferred. However, if the fluff factor of the settled sludge happens to be one, then as shown in Figure 3-15 up to 127,000 gallons (46 in.) of Ttank 241-C-106 sludge can be transferred and stay within the safety guidelines.

Thus, for conservative estimates of fluffing factor, with the operation of the secondary ventilation system, up to 36 inches of waste can be removed from Tank 241-C-106 without exceeding the Tank 241-AY-102 temperature limits. This provides 1 foot of margin for achieving the phase 1 goal of a $2 \mathrm{ft}$ waste transfer. 
Figure 3-13. Temperature Distribution of the Combined Sludge in Tank 241-AY-102 using W-030 Primary Ventilation System with $150 \mathrm{CFM}$ at 70 F Floor Cooling Channel Flow and a) $10 \%$ and b) $50 \%$ heat in Supernatant and the remaining in Sludge.

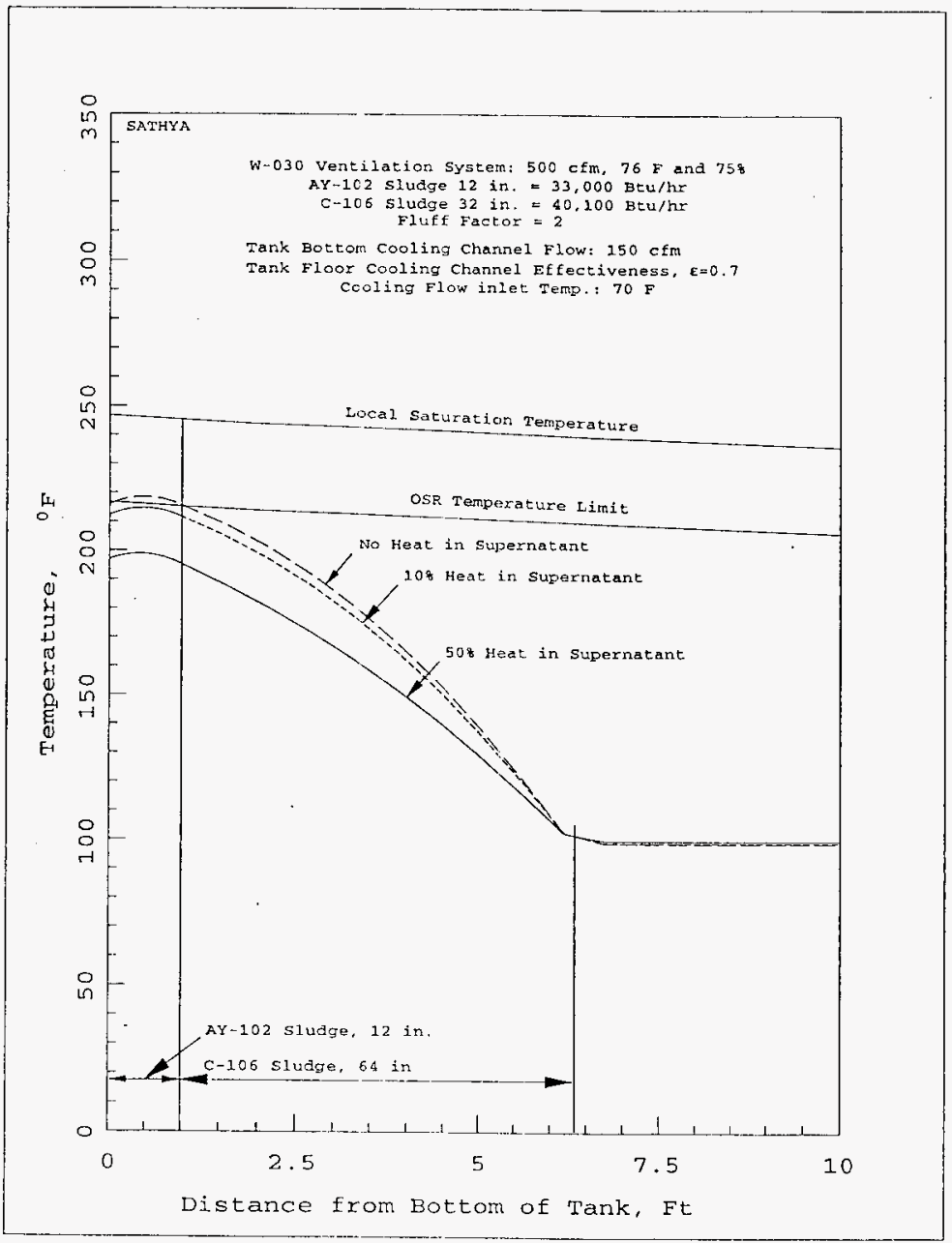


Figure 3-14. Temperature Distribution of the Combined Sludge in Tank 241-AY-102 using W-030 Primary Ventilation System with 150 CFM at 70 F Floor Cooling Channel Flow for Different Quantities of Sludge with Fluff Factor of 2. Heat Generation Rates correspond to $110,000 \mathrm{Btu} / \mathrm{hr}$ Tank Heat Load.

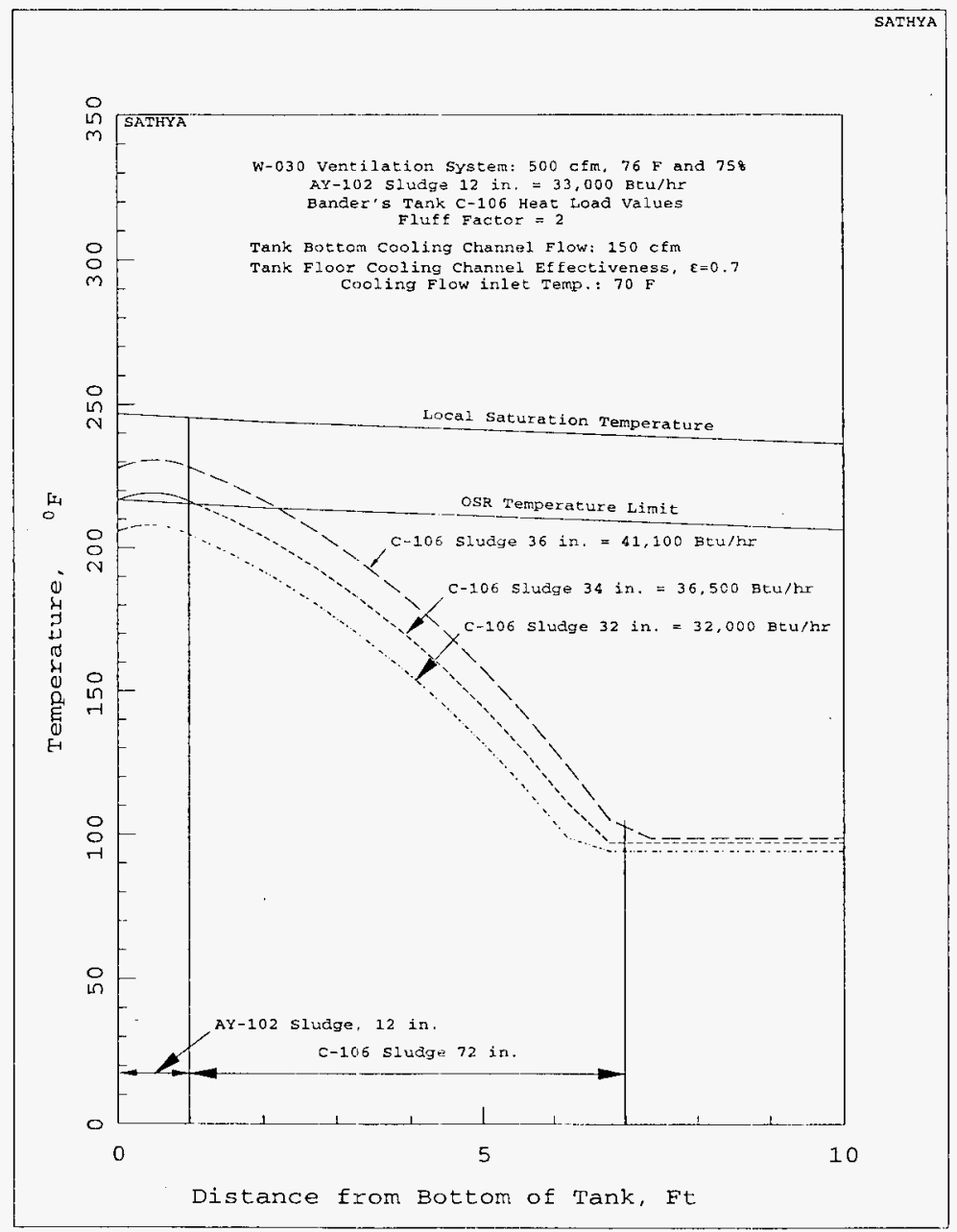


Figure 3-15. Temperature Distribution of the Combined Sludge in Tank 241-AY-102 using W-030 Primary Ventilation System with 150 CFM at 70 F Floor Cooling Channel Flow for Different Quantities of Sludge with Fluff Factor of 1 . Heat Generation Rates correspond to $110,000 \mathrm{Btu} / \mathrm{hr}$ Tank Heat Load.

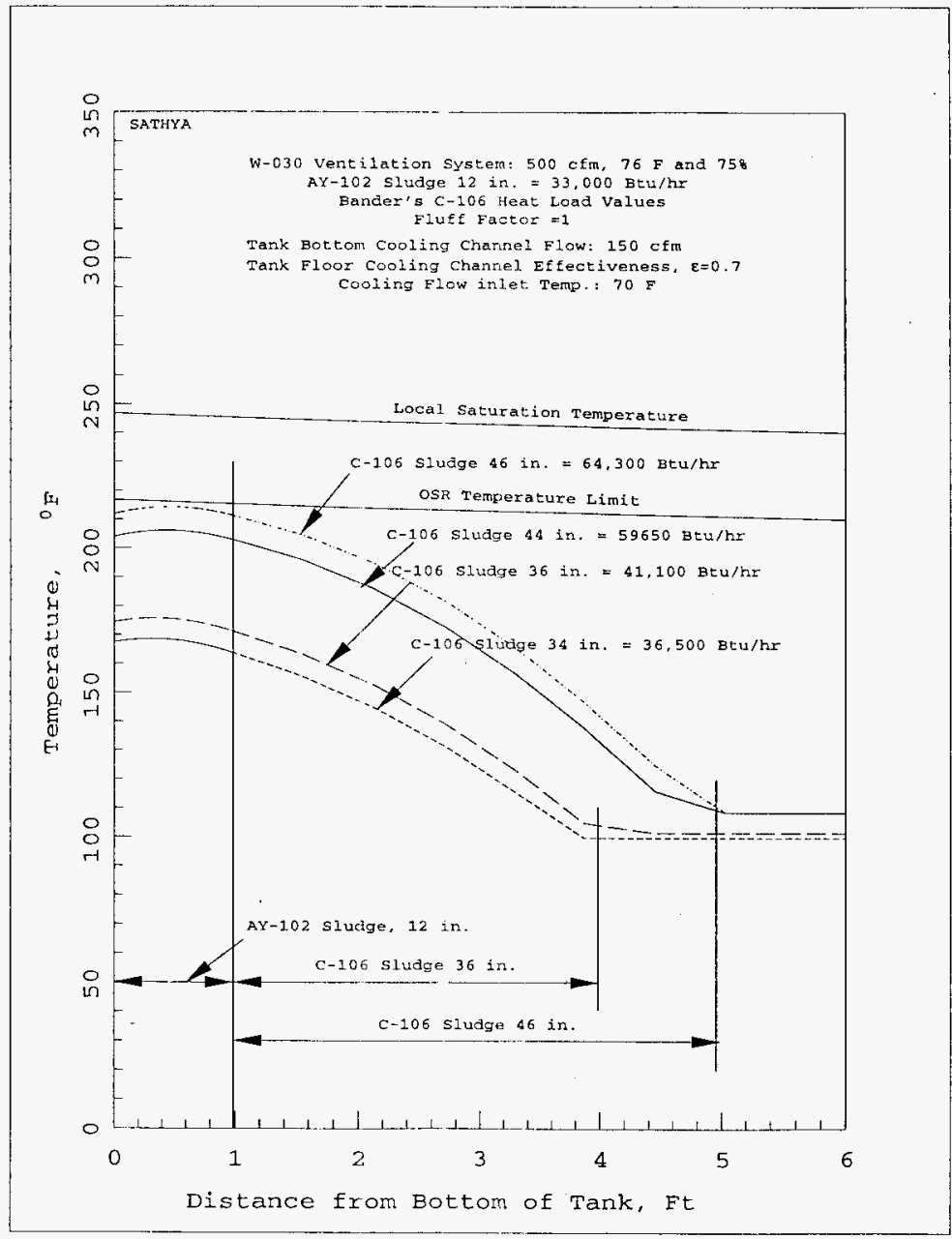


HNF-SD-W320-ER-002, Rev. 0

\subsubsection{Heat Generation Rate Parmetric Analyses}

Further thermal evaluations were performed to assess the consequences of using higher heat generation rates corresponding to the total tank heat load of $132,400 \mathrm{Btu} / \mathrm{h}$. These evaluations also include the effect of using the current 702-A primary ventilation system. In this case, the heat source values used correspond to $1.9 \mathrm{Btu} / \mathrm{h}-\mathrm{ft}^{3}$ for the top $2 \mathrm{ft}$ and $7.9 \mathrm{Btu} / \mathrm{h}-\mathrm{ft}^{3}$ for the bottom ( $\sim \mathrm{ft}$ ) part of the Tank 241-C-106 sludge (see Table 3-2). As before, the W-030 system is assumed to provide Tank $241-\mathrm{AY}-102$ with $500 \mathrm{cfm}$ flow at an effective temperature of $76^{\circ} \mathrm{F}$ and $75 \%$ humidity. The fluff factor of the settled sludge is considered as 2 , and the effectiveness of the cooling channels as 0.7 and a flow of $150 \mathrm{cfm}$. Figure 3-16 shows the effect of transferring higher volumes of sludge starting from 66,000 gallons ( $24 \mathrm{in}$.) to 88,000 gallons (32 in.) of 'Tank 241-C-106 waste into Tank 241-AY-102. It can be seen that a maximum of 88,000 gallons ( 32 in.) of Tank 241-C-106 sludge can be transferred to Tank 241-AY-102 and still stay within the safety guidelines.

For this volume of sludge transfer, the effect of using the 702-A primary system was evaluated. The primary ventilation flow with the $702-\mathrm{A}$ system is assumed to provide $630 \mathrm{cfm}$ flow at an inlet temperature of $70^{\circ} \mathrm{F}$ and $50 \%$ relative humidity. Figure 3-17 shows the effect on sludge temperature distribution for the settled sludge in Tank 241-AY-102 using either the 702-A system or W-030 system with 630 and $500 \mathrm{cfm}$ respectively and the tank floor cooling channel flow of $150 \mathrm{cfm}$ and no flow. The results show that for 88,000 gallons (32 in.) of Tank 241-C106 sludge transfer, the peak sludge temperatures will be close to OSR temperature limits if the secondary ventilation system is operating normally supplying $150 \mathrm{cfm}$ flow to the floor cooling slots. This provides a margin of safety for the phase 1 goal of $2 \mathrm{ft}$ waste transfer.

\subsubsection{Effect of Reduced Primary Ventilation Flow}

The primary ventilation system (702-A), which supplies air to all four Tanks (241-AZ-101, 241-AZ-102, and 241-AY-101 and 241-AY-102) of the AWF is being replaced under Project W030 . The $W-030$ system will be able to run with three operating modes. Under the normal or recirculation mode, a total tank inflow of $500 \mathrm{cfm}$ with $400 \mathrm{cfm}$ recirculated and $100 \mathrm{cfm}$ exhausted through the stack. Under the high heat mode of operation, one of the four tanks will have more than $100 \mathrm{cfm}$ going to the exhaust fan (up to $500 \mathrm{cfm}$ ). The third mode of operation is the bypass mode. In this mode of operation, the recirculation system is not being used, and the flow rate of each tank will be only $100 \mathrm{cfm}$. Therefore, the thermal analysis has been performed using only $100 \mathrm{cfm}$ of primary ventilation flow to evaluate its effect on the amount of Tank 241C -106 sludge transfer to Tank $241-A Y-102$. For this calculation, it is assumed that the primary ventilation flow of $100 \mathrm{cfm}$ enters the tank with an inlet temperature of $70^{\circ} \mathrm{F}$ and $50 \%$ relative humidity. The tank floor cooling channels still will have a flow of $150 \mathrm{cfm}$, and the cooling channels will have a cooling effectiveness of 0.7 . If the transferred Tank $241-\mathrm{C}-106$ sludge in lank 241-AY-102 has a fluffing factor of two, then the transfer of 88,000 gallons (32 in.) of sludge containing about $40,100 \mathrm{Btu} / \mathrm{h}$ heat load will reach sludge temperatures above local saturation values as shown in Figure 3-18. If the primary ventilation flow drops to $100 \mathrm{cfm}$, then to stay within the safety guidelines, a maximum of 74,250 gallons ( 27 in.) of 
HNF-SD-W320-ER-002, Rev. 0

Tank 241-C-106 can be stored in Tank 241-AY-102. Thus the phase 1 goal can be met, but the margin of safety is reduced. 
Figure 3-16. Temperature Distribution of the Combined Sludge in Tank 241-AY-102 using W-030 Primary Ventilation System with 150 CFM at 70 F Floor Cooling Channel Flow for Different Quantities of Sludge with Fluff Factor of 2. Heat Generation Rates correspond to 132,400 Btu/hr Tank Heat Load.

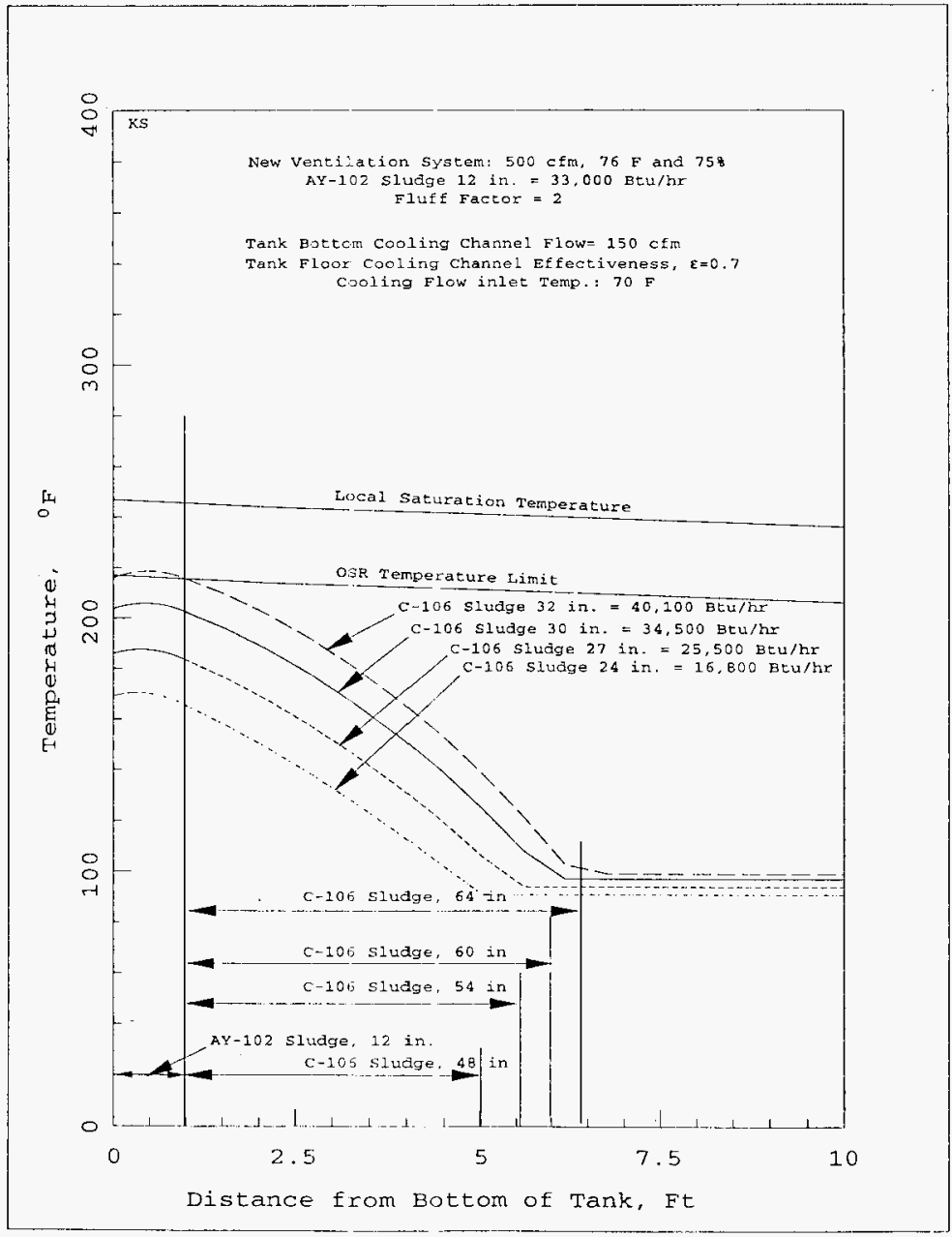


Figure 3-17. Temperature Distribution of the Combined Sludge in Tank 241-AY-102 using W-030 and 702-A Primary Ventilation System with 0 and 150 CFM at 70 F Floor Cooling Channel Flow for 88,000 gallons(32 in.) of Sludge with a Heat Load of 40,100 Btu/hr and Fluff Factor of 2 . Heat Generation Rate corresponds to 132,400 Btu/hr Tank Heat Load.

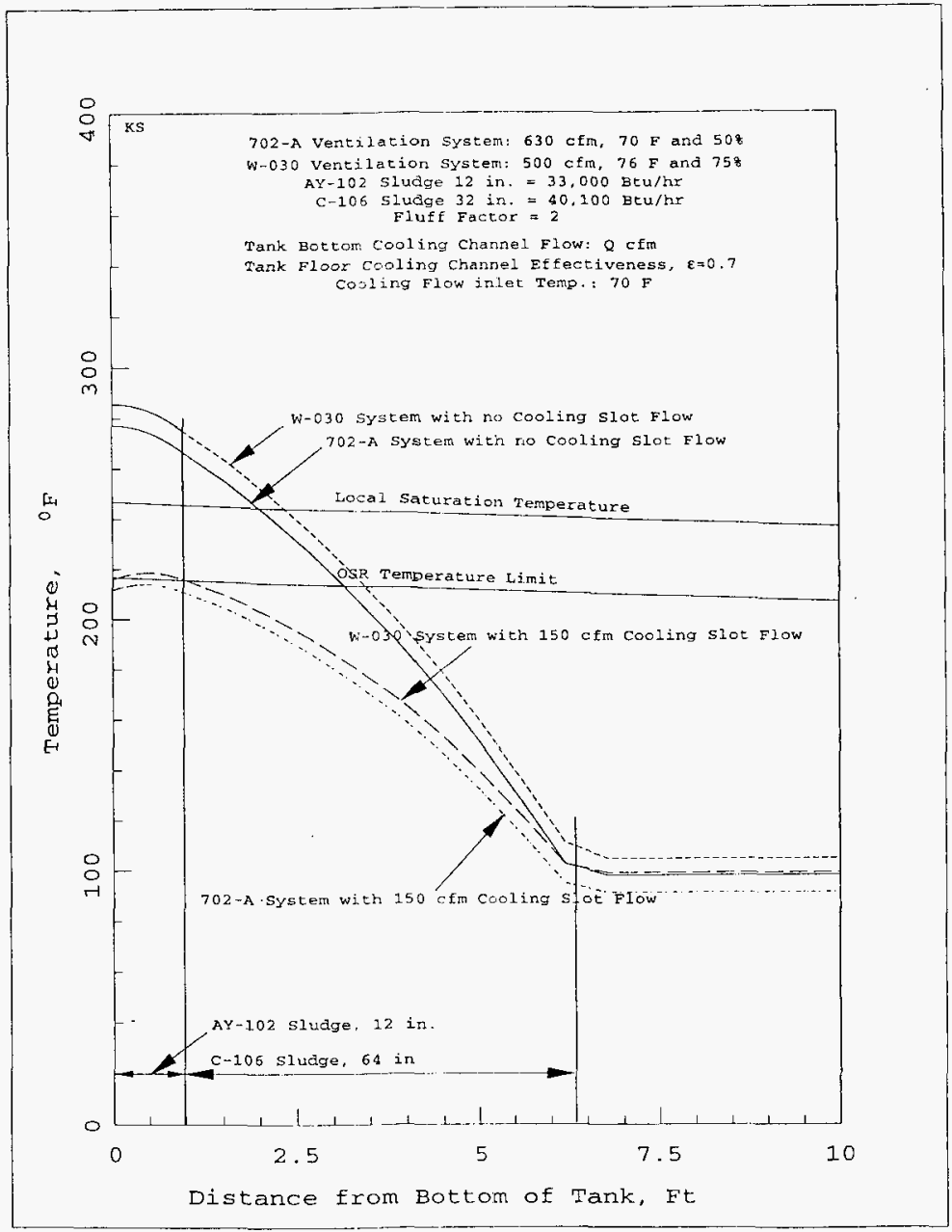


Figure 3-18. Temperature Distribution of the Combined Sludge in Tank 241-AY-102 using 100 CFM of W-030 Primary Ventilation System Flow and 150 CFM Floor Cooling Channel Flow for Different Quantities of Sludge with Fluff Factor of 2. Heat Generation Rates correspond to $132,400 \mathrm{Btu} / \mathrm{hr}$ Tank Heat Load.

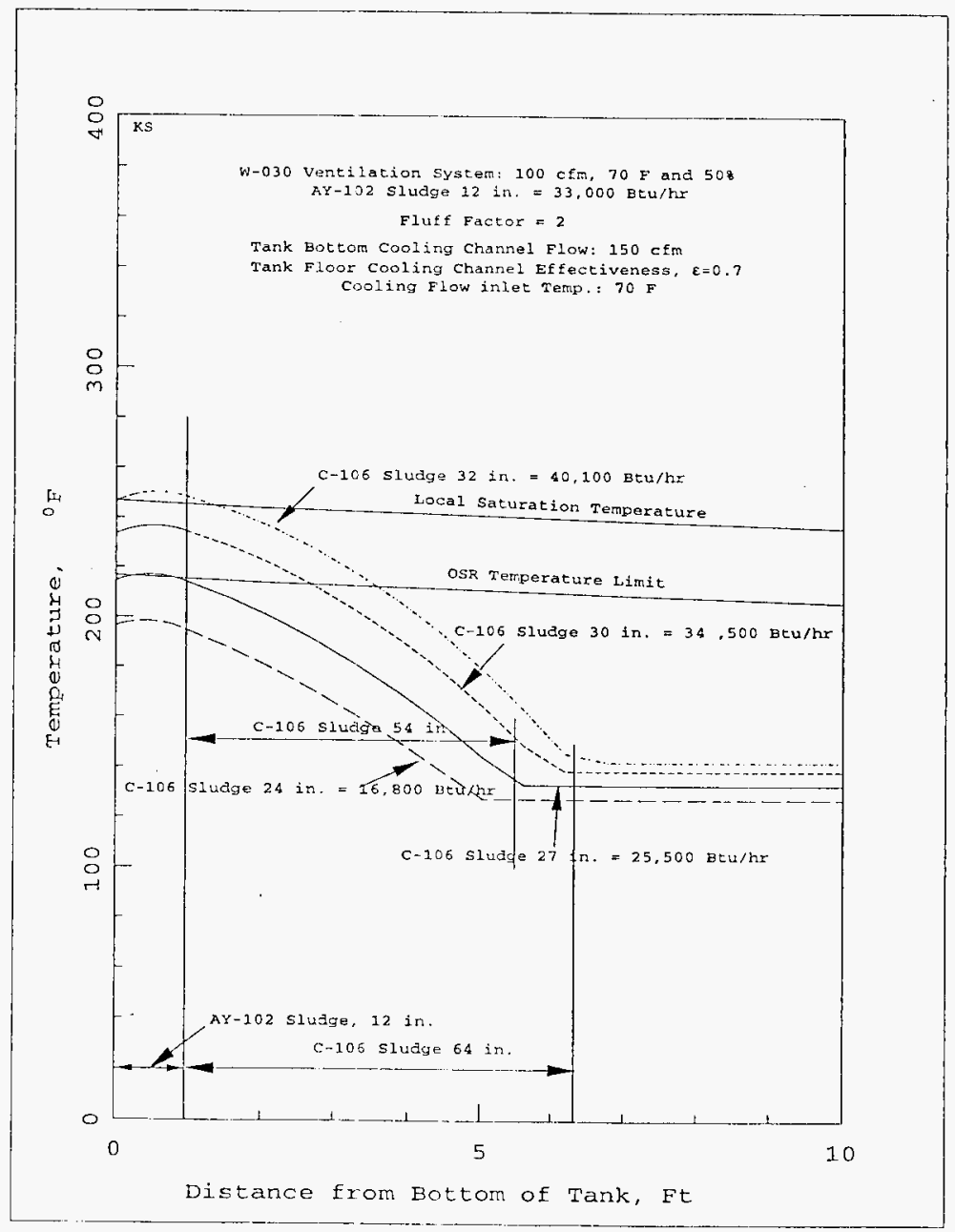




\subsection{WASTE RETRIEVAL POTENTIAL UNDER OPTIMISTIC CONDITIONS}

Safety guidelines limit the peak sludge temperature to $30^{\circ} \mathrm{F}$ below the local saturation temperature to prevent the formation of steam that can result in a steam bump and to $350^{\circ} \mathrm{F}$ to preserve tank structural integrity. The important parameters that control the peak sludge temperatures are settled sludge height (conduction length) and heat generation rate for any given operating conditions of the tank. The total tank heat load has been estimated to be a minimum of $110,000 \mathrm{Btu} / \mathrm{h}$ (Bander 1993) to as high as 132,400 Btu/h (Fryer 1996).

The sludge volume in receiver Tank 241-AY-102 depends on the settling behavior of the Tank 241-C-106 sludge. Recent bench-scale tests (Brooks, et al 1997) of enhanced sludge washing and gravity settling of Tank 241-C-106 sludge has shown that the final solids concentration in the sediment was a minimum of $14 \mathrm{wt} \%$ after first leaching with $3 \mathrm{M} \mathrm{NaOH}$, $22 \mathrm{wt} \%$ after first water wash to a maximum of $32 \mathrm{wt} \%$ after complete enhanced sludge washing. TWRS planning document assumed a solids concentration of $20 \mathrm{wt} \%$ in the final compacted sludge. However, the sludge may compact more in a full-scale tank as a result of a higher sludge level. In addition, compaction will occur after the initial waste transfer and settling. Also, the current solids concentration in Tank 241-C-106 sludge will decrease with the dissolution of some of the water soluble compounds. Recent analysis using ESP (MacLean 1997) results show that $25 \%$ of the precipitate will dissolve while sluicing. If $25 \%$ of precipitants dissolve while sluicing, then it will be reasonable to expect a fluffing factor of 1.5 which can further be reduced by increasing the caustic addition before sluicing to dissolve the $\mathrm{Al}(\mathrm{OH}) 3$, and perhaps the $\mathrm{Na}$ Oxalate(Mac Lean 1997). These optimistic, but possible, combination of conditions may result in a much reduced sludge volume. In the best case, the volume of the transferred Tank 241-C-106 sludge in Tank 241-AY-102 may be the same as in Tank 241-C-106 currently. This situation will mean that the fluff factor of the sludge will be one (Reynolds 1997).

The heat load of $110,000 \mathrm{Btu} / \mathrm{h}$ (Bander 1993) was estimated using the measured tank waste temperatures. The GOTH simulations performed for the 1994 process test have shown a heat load of 132,400 Btu/h (Fryer 1995) will be required to provide a better comparison with the measured waste level data. However, the maximum heat content estimate made based on the 1996 grab sample ${ }^{137} \mathrm{Cs}$ and ${ }^{90} \mathrm{Sr}$ content is $111,400 \mathrm{Btu} / \mathrm{h}$ (Babad 1996). Because of the variability in the sample values and the uncertainties in the radionuclide distribution in the sludge, the heat load estimate may not be as reliable (Babad 1996) as that estimated using measured waste temperature data. Taking into account the decay of radionuclides, the 1994 estimate of $132,400 \mathrm{Btu} / \mathrm{h}$ heat load will be about $123,000 \mathrm{Btu} / \mathrm{h}$ in 1997 . Under optimistic conditions, it is assumed that the heat load of the transferred Tank 241-C-106 sludge will not be more than $110,000 \mathrm{Btu} / \mathrm{h}$.

Based on 1996 grab sample analyses, the heat generating radionuclides ${ }^{137} \mathrm{Cs}$ and ${ }^{90} \mathrm{Sr}$ are about equal proportion in curie content at least in top layers of the sludge. However, there is no basis to assume that it is true throughout the sludge. Also, ${ }^{90} \mathrm{Sr}$ produces about 1.4 times as much heat per curie as that of ${ }^{137} \mathrm{Cs}$. In addition PNNL bench scale tests have shown that not all of the ${ }^{137} \mathrm{Cs}$ will dissolve in supernate but up to $60 \%$ may remain in the sludge. It is estimated that the 
heat generation rate (Estey, 1997) due to the presence of ${ }^{137} \mathrm{Cs}$ is less than $10,000 \mathrm{Btu} / \mathrm{h}$ which is about 8 to $9 \%$ of the total tank heat load. Therefore under optimistic conditions the heat load in the transferred 197,000 gallons of sludge may be about a maximum of $10 \%$ less heat. If the radionuclides ${ }^{137} \mathrm{Cs}$ and ${ }^{90} \mathrm{Sr}$ content is the same throughout as in the top layers of the sludge and if $60 \%$ of ${ }^{137} \mathrm{Cs}$ is dissolved in Tank $241-\mathrm{AY}-102$ supernatant, then it may be possible for the sludge to have $20-25 \%$ less heat load.

Analyses were performed with this optimistic set of assumptions for complete transfer of Tank 241-C-106 waste. The sludge temperature distribution in Tank AY-102 is determined and the results for a fluff factor of 1.0 are shown in Figure 3-19. As shown in this figure, the total heat load of the transferred sludge is $110,000 \mathrm{Btu} / \mathrm{hr}$ and the settled sludge fluff factor is $1.0 . \mathrm{A}$ $20 \%$ heat load is assumed to be in the supernate and the remaining $80 \%$ is in the sludge. Under these conditions, to limit the peak sludge temperatures within safety limits, the floor channel flow should be increased to 500 CFM. If the fluff factor is 1.5 , then the slot cooling flow should be increased to 900 CFM as shown in Figure 3.20 to remain within the safety guidelines.

Given an optimistic set of assumptions for fluffing factor, heat load, and its distribution between sludge and supernatant, complete retrieval of Tank 241-C-106 sludge can be accomplished using about $1000 \mathrm{cfm}$ secondary system floor cooling channel flow. Theannulus/floor channel flow evaluation presented in section 2.0 shows that this flow is possible with the minimum secondary system modification of blocking the wall annulus flow and allowing high annulus vacuum. 
Figure 3-19. Temperature Distribution of the Combined Sludge in Tank 241-AX-102 using W-030 Primary Ventilation System with 150 and 500 CFM at 70 F Floor Cooling Channel Flow for 197,000 gallons of Sludge having a Heat load of 110,000 Btu/hr and with Fluff Factor of 1.

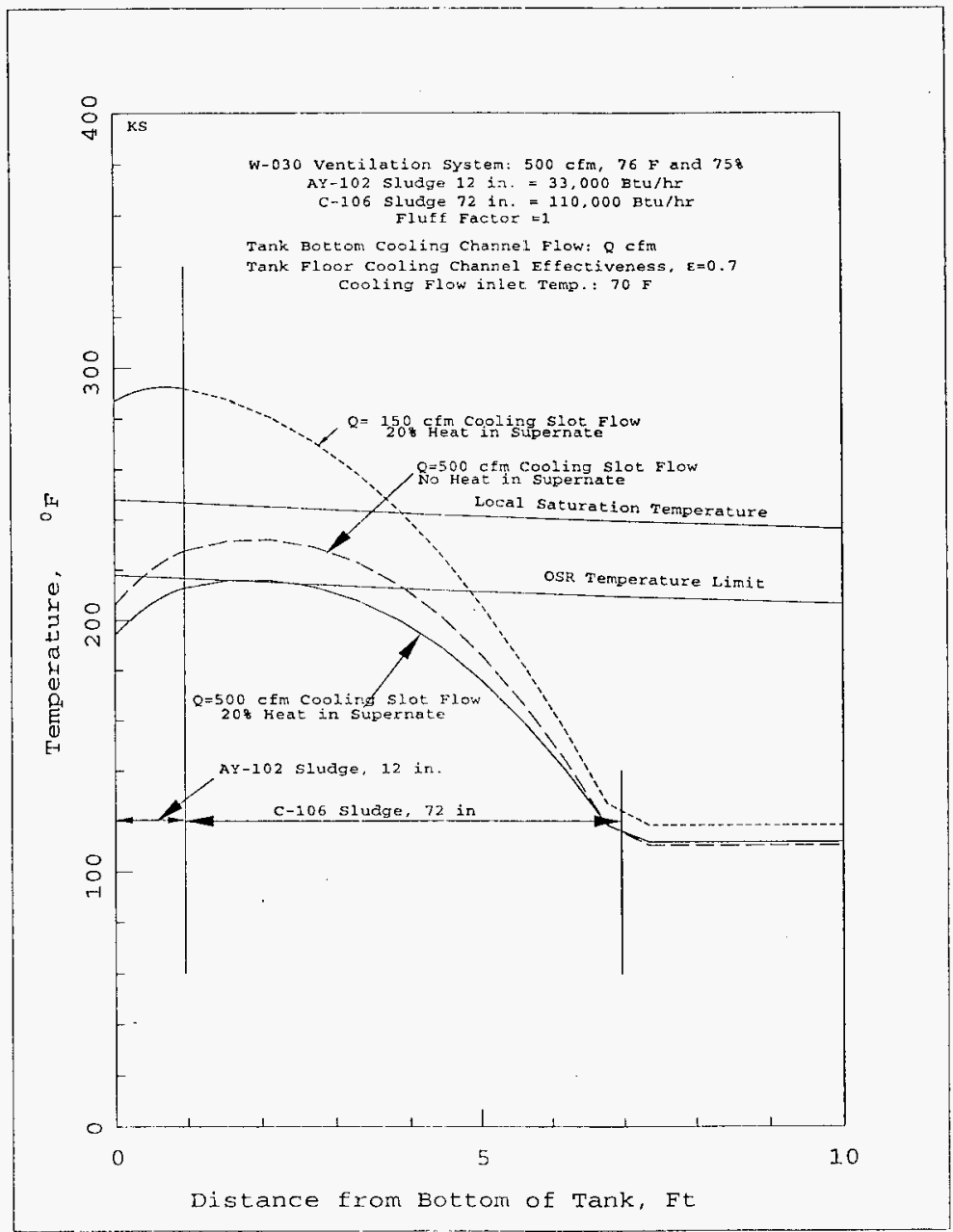


Figure 3-20. Temperature Distribution of the Combined Sludge in Tank 241-AY-102 using W-030 Primary Ventilation System with Different Air Flows Through Floor Cooling Channels for 197,000 gallons of Sludge having a Heat Load of $110,000 \mathrm{Btu} / \mathrm{hr}$ and with a Fluff Factor of 1.5 .

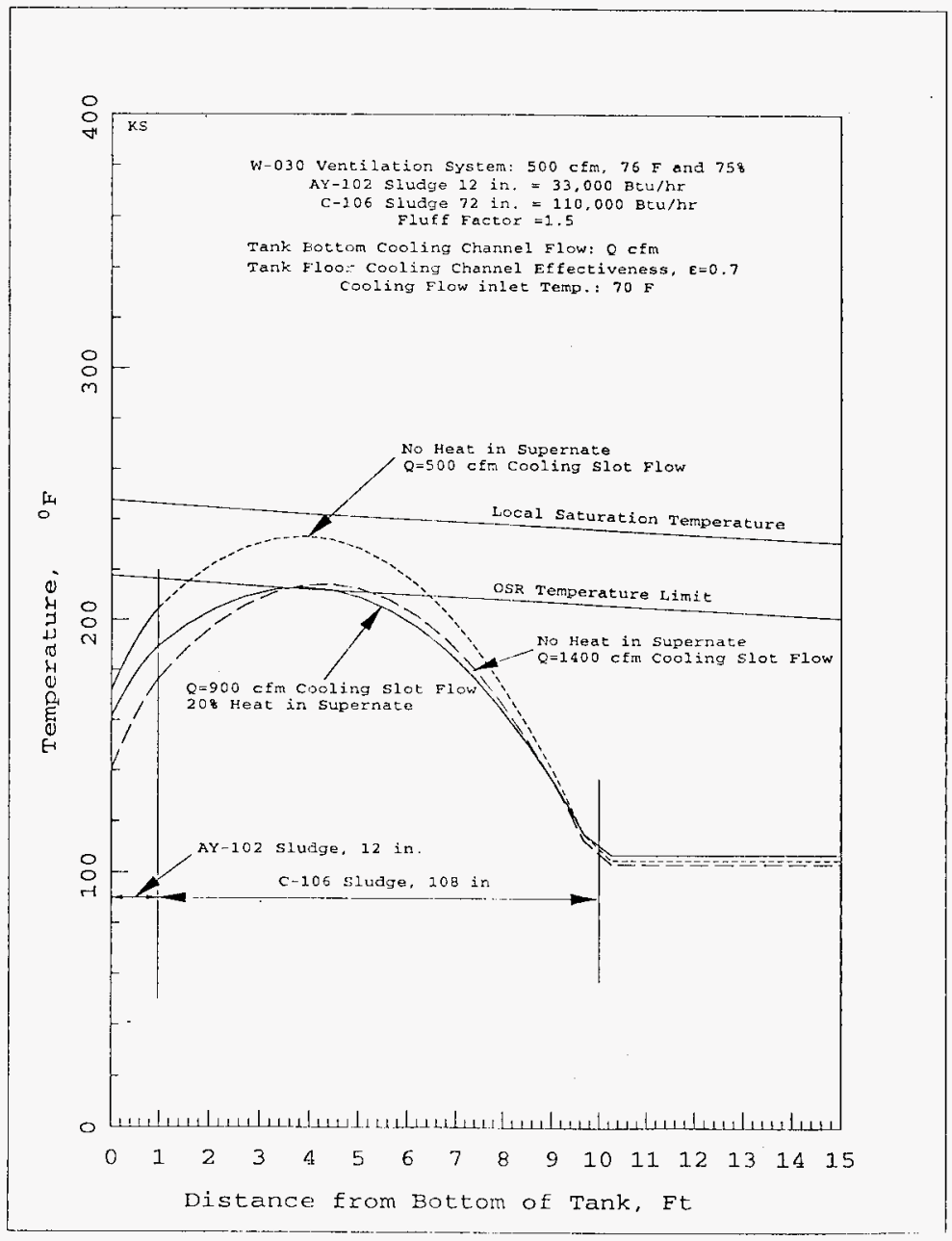




\subsection{TRANSIENT THERMAL EVALUATION}

The steady state analyses documented in the previous sections were for long term storage of the waste in Tank 241-AY-102. To assess the transient thermal behavior of waste transfer in Tank 241-AY-102, a simple closed form analytical solution was used. The solution for a solid with an initial uniform temperature distribution which is bounded by two parallel planes (Carslaw and Jaeger) was used for this evaluation. One bounding plane is at a constant temperature and the second is a zero heat flux boundary.

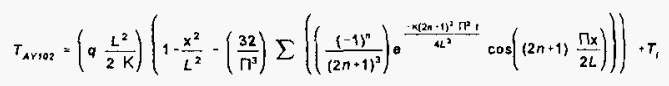

where:

$$
\begin{aligned}
& x=\text { location of interest in the slab } \\
& L=\text { slab thickness } \\
& t=\text { transient time } \\
& T_{i}=\text { initial and boundary temperature } \\
& K=\text { thermal diffusivity } \\
& k=\text { thermal conductivity } \\
& q=\text { volumetric heat flux }
\end{aligned}
$$

The purpose of the evaluation was to determine the amount of time required to reach steady state temperatures in the sludge of Tank 241-AY-102 after an incremental transfer of waste from Tank 241-C-106. The analysis makes the simplifying assumption that the supernatant is at a constant temperature during the temperature transient. The important parameters are:

Volumetric heat generation

$$
q\left(B t u / h / f^{3}\right)=\frac{\left(\frac{33000+28150}{2.5 * L_{c 106}}\right)}{4418\left(1+f l u f f * L_{c 106}\right)}
$$


Thermal conductivity

$$
\mathrm{k}_{\mathrm{AY} 102}\left(\mathrm{Btu} / \mathrm{h} / \mathrm{ft}^{\circ} \mathrm{R}\right)=0.4
$$

Thermal diffusivity

$$
K(\mathrm{lbm} / \mathrm{h}))=k_{\text {AY102 }} \frac{\left(1+\text { fluff } * L_{C 106}\right)}{\left(60.07+52.23 * \text { fluff } * L_{C 106}\right)}
$$

Initial and boundary temperature

$$
\mathrm{T}\left({ }^{\circ} \mathrm{F}\right)=70
$$

Sludge thickness

$$
L_{\text {AY102 }}(f t)=1+f l u f f * L_{C 106}
$$

The thermal transient behavior for varying fluff factors is shown in Figure 3-21. Time to reach steady state exceeds 3 months for a 2 foot transfer from 241-C-106. Figure 3-22 shows the time to reach steady state and the associated time constant. These analyses show that the thermal time constant for tank 241-AY-102 is quite large.

The sensitivity to the fluff factor for a 1.5 foot transfer is shown in Figure 3-23. The fluff factor increases the thermal time constant since the total volume of waste and thus the heat capacity increases.

These analyses demonstrate that the thermal time constant can be many months. Process control using the maximum steady state temperature will not be possible. However, the thermal transient response can be characterized through computer modeling and the expected steady state temperature can be evaluated from the short term transient waste temperature response. This will allow for maximum waste transfer without delaying the project because of the large thermal time constant. 
HNF-SD-W320-ER-002, Rev. 0

Figure 3-21. Transient Temperatures for Combined Sludge in Tank 241-AY-102 For Different Amonts of Waste Transferred from Tank 241-C-106 Assuming a Fluff Factor of 2.

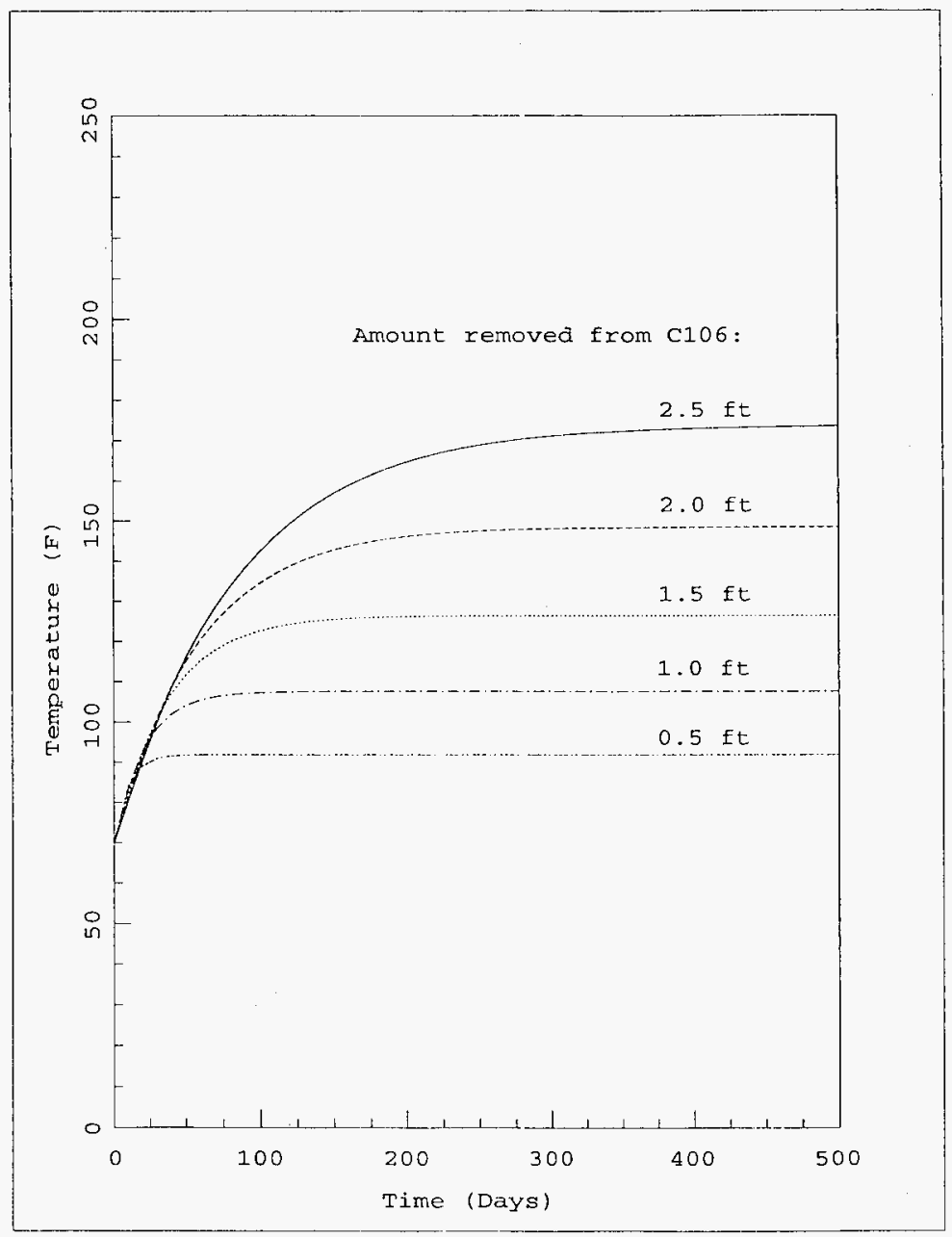


HNF-SD-W320-ER-002, Rev. 0

Figure 3-22. Thermal Time Constant and Time to Reach Steady State as a Function of Quantity of Sludge Transfer From Tank 241-C-106 to Tank 241-AY-102 Assuming the Fluff Factor of 2 for the Transferred Sludge.

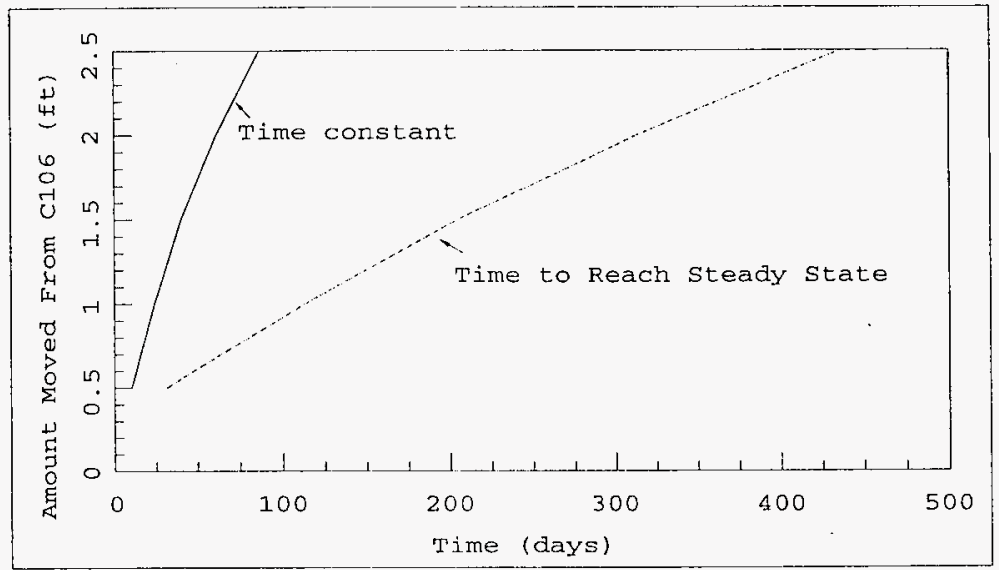


HNF-SD-W320-ER-002, Rev. 0

Figure 3-23. Transient Temperature of the Combined Sludge For $1.5 \mathrm{ft}$ of Tank 241-C-106 Sludge Transfer with Flufing Factor as a Parameter.

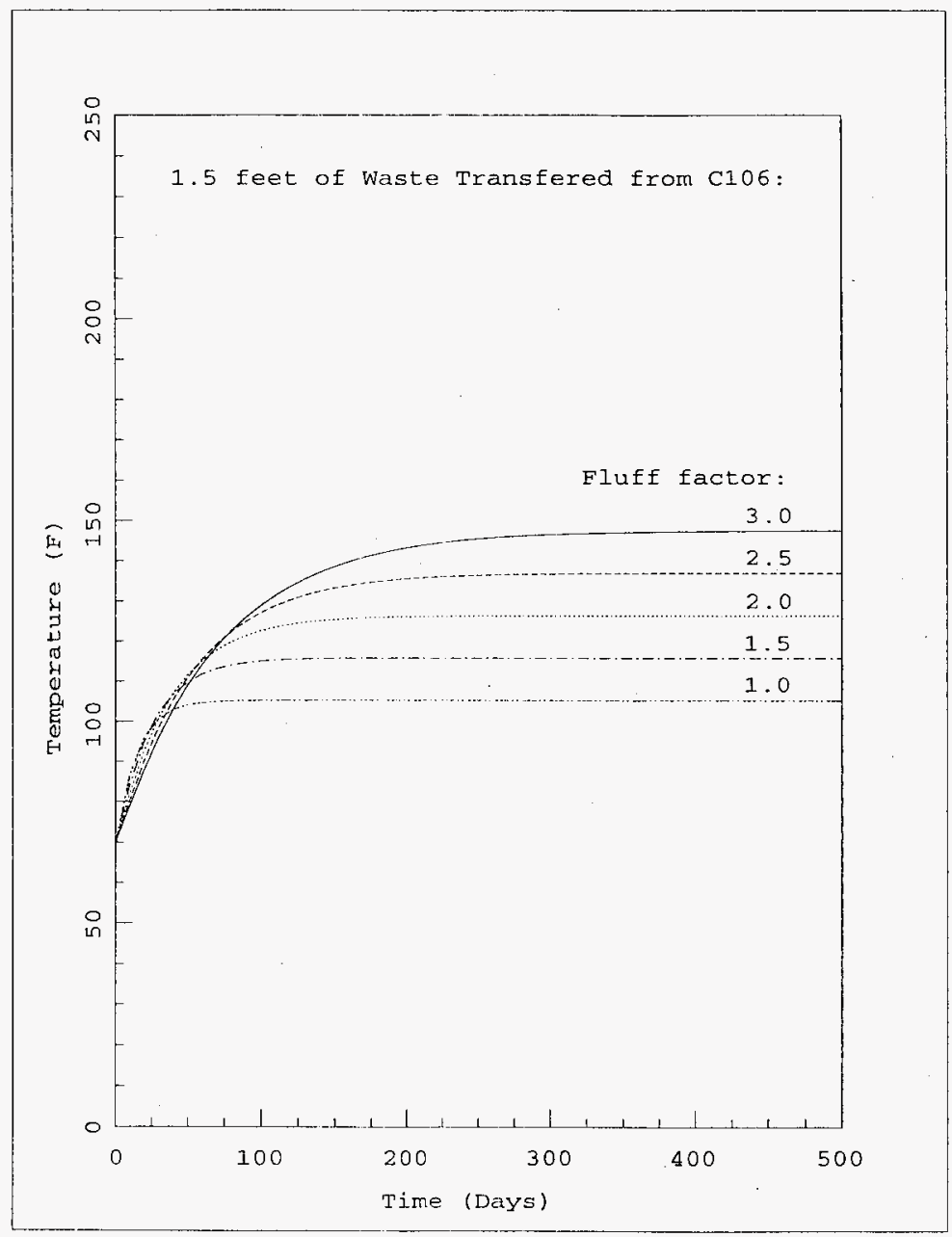




\subsection{PROCESS CONTROL CONSIDERATIONS}

Temperature limits have been established for tanks 241-C-106 and 241-AY-102 to eliminate the potential for a steam bump during retrieval and storage operations. Process control plan is described to maintain the waste temperatures within the safety guidelines. The following sections discuss process control strategies for tanks 241-C-106 and 241-AY-102.

\subsection{TANK 241-AY-102}

The maximum waste temperature must be less than $30^{\circ} \mathrm{F}$ below the local saturation temperature for Tank 241-AY-102. With sufficient instrumentation, it may be possible to measure the maximum waste temperature $\left(T_{\max }\right)$ directly. However, as shown in section 3.7 , the thermal time constant is quite large. Thus the maximum steady state temperature resulting from any waste transfer into 241-AY-102 will not be reached until long after the transfer is complete. Therefore, it will not be possible to use the steady state temperature for process control.

The maximum temperature $T_{\max }$ is a function of the non-convective waste level (L), the heat load within the nonconvective waste $(\mathrm{Q})$ and the waste thermal conductivity $(\mathrm{k})$,

$$
T_{\text {max }}=f\left(L^{2}, Q, K\right) .
$$

Both $\mathrm{L}$ and $\mathrm{Q}$ are a function of the mass of waste transferred from 241-C-106. The temperature control strategy for 241-AY-102 is to monitor and control the mass transfer from 241-C-106 while monitoring temperatures in 241-AY-102. A computer model will then be used to evaluate the transient temperature response to determine the maximum steady state temperature. This process control strategy is summarized in Table 4-1. Parameters which are measured directly are shown in the table with bold print. The other parameters are inferred through a functional dependence on the measured parameters.

Process control is provided by monitoring and controlling the mass transferred. From this initial measured parameter, $\mathrm{L}, \mathrm{Q}, \mathrm{K}_{\mathrm{AY} 102}$ and the maximum steady state temperature $\mathrm{T}_{\max }$ can be inferred and temperature control maintained. After the initiation of waste transfer to 241-AY102 , an in-process monitoring and evaluation will begin. This monitoring and evaluation will provide information to update important thermal parameters such as settled waste fluffing factor, tank energy balance, settled waste level and the spacial and temporal waste temperature distribution. This information will be used to perform an evaluation of the transient temperature behavior. The maximum steady state temperature can then be determined through computer analyses. Through the in-process sluicing evaluation, the waste transfer to 241-AY-102 can be maximized while maintaining the required temperature control. 
HNF-SD-W320-ER-002, Rev. 0

Table 4-1. Process Control Considerations for Tank 241-AY-102

\begin{tabular}{|c|c|c|c|c|c|}
\hline & \multirow[b]{2}{*}{$\begin{array}{l}\text { Measured } \\
\text { Information }\end{array}$} & \multicolumn{3}{|c|}{ Required AY102 Information } & \multirow[b]{2}{*}{$\begin{array}{c}\text { AY } 102 \\
\text { Key Parameters } \\
\text { Twaste/Lmax }\end{array}$} \\
\hline & & $\begin{array}{c}\text { L } \\
\text { Settled Solids } \\
\text { Level }\end{array}$ & $\begin{array}{c}Q \\
\text { Tank } \\
\text { Heat Load }\end{array}$ & $\begin{array}{c}\mathrm{K}_{\mathrm{AY} 102} \\
\text { Waste Thermal } \\
\text { Conductivity }\end{array}$ & \\
\hline $\begin{array}{l}\text { Process } \\
\text { Control }\end{array}$ & Mass Balance & $L$ (mass, FF) & $Q$ (mass, $C_{106}$ heat load) & $\mathrm{K}_{\mathrm{AY} 102}$ (mass, $\left.\mathrm{FF}, \mathrm{K}_{\mathrm{Cl} 106}\right)$ & $\begin{array}{c}\left.\text { Twaste (L, Q, } \mathrm{K}_{\mathrm{AY} 102}\right) \\
\mathrm{Lmax}\left(\mathrm{L}, \mathrm{Q}, \mathrm{K}_{\mathrm{AY} 102}, \text { Timax }\right. \\
\end{array}$ \\
\hline \multirow{4}{*}{$\begin{array}{l}\text { In-Process } \\
\text { Sluicing } \\
\text { Evaluation }\end{array}$} & \multirow{2}{*}{ Heat Balance } & $L$ (mass, FF) & $\mathrm{Q}$ (mass, $C 106$ heat load) & $K_{A Y 102}$ (mass, $F F, K_{C 106}$ ) & Twaste $\left(\mathrm{L}, \mathbf{Q}, \mathrm{K}_{A Y 102}\right)$ \\
\hline & & $L$ (mass, FF) & $\begin{array}{c}\mathrm{Q} \text { (mass, } \mathrm{Cl} 06 \text { heat ioad) } \\
\text { energy balance }\end{array}$ & $\mathrm{K}_{\mathrm{AY} 102}$ (mass, $\mathrm{FF}, \mathrm{K}_{\mathrm{C} 106}$ ) & $\begin{array}{c}\text { Twaste }\left(\mathrm{L}, \mathrm{Q}, \mathrm{K}_{\mathrm{AY} 102}\right) \\
\operatorname{Lmax}\left(\mathrm{L}, \mathrm{Q}, \mathrm{K}_{\mathrm{AY} Y 02}, \operatorname{Tmax}^{2}\right)\end{array}$ \\
\hline & Waste Level & $\begin{array}{c}L(\text { mass, } F F) \\
\text { Enraf }\end{array}$ & $\begin{array}{l}\mathrm{Q} \text { (mass, C106 heat load) } \\
\text { energy balance }\end{array}$ & $\begin{array}{c}\left.K_{A Y 102} \text { (mass, } \mathrm{FF}, \mathrm{K}_{\mathrm{C} 106}\right) \\
\mathrm{K}_{\mathrm{AY} 102}\left(\text { waste level, } \mathrm{K}_{\mathrm{Cl} 106}\right)\end{array}$ & $\begin{array}{c}\text { Twaste }\left(L, Q, K_{A Y Y I I I}\right) \\
L \operatorname{Lmax}\left(L, Q, K_{A Y Y 02}, T_{\max }\right)\end{array}$ \\
\hline & $\begin{array}{c}\text { Waste } \\
\text { Temperature }\end{array}$ & $\underset{\text { Enraf }}{L \text { (mass, FF) }}$ & $\begin{array}{c}Q \text { (mass, C106 heat load) } \\
\text { energy balance }\end{array}$ & $\begin{array}{c}\left.\mathrm{K}_{\mathrm{AY} 102} \text { (mass, } \mathrm{FF}, \mathrm{K}_{\mathrm{C} 106}\right) \\
\mathrm{K}_{\mathrm{AY} 102}\left(\text { waste level, } \mathrm{K}_{\mathrm{Cl} 106}\right)\end{array}$ & $\begin{array}{c}\text { Twaste } \\
L \operatorname{Lmax}\left(\mathbf{L}, \mathbf{Q}, \mathrm{K}_{\mathrm{AY} 102}, T_{\max }\right)\end{array}$ \\
\hline
\end{tabular}

\subsection{Tank 241-C-106}

The waste in tank 21-C-106 will be cooled below the local saturation temperature (subcooled) prior to sluicing through the operation of an inlet chiller. This subcooling must be maintained at all times during the retrieval operation. As the waste level is decreased through sluicing, the saturation temperature at the location of the maximum waste temperature will decrease, thus decreasing the subcooling margin. A previous evaluation (Bander, 1996) showed that the subcooling margin could be maintained if the pool liquid level was maintained during sluicing and a cooling period was provided prior to reducing the liquid level. Thus the process control strategy for 241-C-106 will be to maintain the pool liquid level during sluicing followed by a hold period for cooling. The primary process control parameter will be the duration of the hold period. Available instrumentation for 241-C-106 does not measure the maximum waste temperature directly. In addition, the thermal time constant for 241-C-106, like 241-AY-102, is large. Thus, the primary process control parameter will be determined through computer modeling. The computer models used for process control in 241-C-106 are discussed in the following sections.

\subsubsection{GOTH Process Control Model Description}

Tank 241-C-106 in terms of actual tank dimensions is illustrated in Figure 4-1 together with current thermocouple tree and thermocouple locations.

The GOTH sluicing model is described with the aid of Figures 4-2 and 4-3. Figures 4-2 and 4-3 illustrate the 1-D nodalization, boundary conditions, and heat conductors utilized. The model consists of six initial sludge filled axial nodes plus a dome gas/supernatant node for a total 
of seven axial nodes. Boundary conditions for inlet and outlet ventilation and infiltration is included for summer average, chiller, and recycle ventilation conditions. Boundary conditions are also included for sluice injection, sluice removal, and draining. Boundary conditions for water makeup during the summer average, and chiller operating nodes are included to keep the supernatant level constant. No makeup water is added to the tank during sluicing/hold/drainage periods, and therefore there are level decreases due to un-replenished evaporation during those time periods.

Various trips and functions are employed to simulate changing ventilation, sluicing, and draining boundary conditions. Conductors with time varying characteristics are also included in the model to properly simulate the transfer of heat at the sludge supernatant interface.

\subsubsection{Tank 241-C-106 Temperature Control}

During the sluicing operation, the ventilation system operates in a recirculation mode to provide remove water vapor and provide good visibility in the dome. However, this mode of operation significantly reduces the heat removal performance of the system. The initial subcooling margin is maintained or increased by allowing hold periods for cooling. The cooling results from waste removal which decreases the conduction length for heat removal. The GOTH model presented in section 4.2.1 was used to determine the length of the hold period required to maintain the initial subcooling. These analyses were performed for 1 foot incremental sluicing. Because the sluicing will be performed into a liquid pool, waste removal may be limited to 6 inch increments. Analyses are in progress to assess 6 inch incremental sluicing.

\subsubsection{Short (12 Hour) Temperature Control Hold Period.}

If sluicing and draining are continuous without adequate sludge temperature control hold periods, the risk of the sludge near the tank bottom reaching saturation temperature increases. Reduction in sludge/supernatant height without allowing time to come to thermal equilibrium at reduced temperature will lower the pressure at tank bottom such that saturation temperature may be reached. A GOTH simulation was performed for a 1 foot incremental sluicing. The analyses modeled a 90-day summer average steady-state condition, followed by an 83-day chiller operation which achieves near maximum subcooling. The analyses modeled cycles of sluicing 1 foot layers (with constant liquid level) for $\sim 10$ hours, followed by a temperature control hold period of 12 hours, followed by a $\sim 2$ hour drain period to reduce the liquid pool level. Sluice injection water is assumed to be at $72^{\circ} \mathrm{F}$. Dome ventilation is switched from the chiller operation after the 83 day chiller operation to reduced flow in the recycle mode with recycle gas tank in-flow reduced to $860 \mathrm{cfm}$.

The results of the GOTH analyses ( tank bottom waste temperature, saturation temperature, and waste level) are illustrated in Figures 4.4 and 4.5. Chiller operation results in cooling the tank bottom waste and underlying soil by $\sim 4{ }^{\circ} \mathrm{F}$ in 83 days. In this simulation, sluicing is carried out by injecting $380 \mathrm{gpm}$ into each successive $1 \mathrm{ft}$ layer of sludge. During the injection period, $380 \mathrm{gpm}$ of slurrified material is pumped off with the sump pump. Following complete dilution of all particles from each $1 \mathrm{ft}$ layer, the $1 \mathrm{ft}$ layer of original supernatant above the sluicing layer 
is drained off. The complete tank sluicing process would require about 7 days of sluicing and draining, with the 12 hour intervening temperature control hold periods. As shown in Figures 44 and 4-5, saturation temperature decreases as the level and therefore pressure decreases.

However, the actual temperature of the sludge in the bottom of the tank does not decrease as fast as does the saturation temperature. The sludge temperature approaches saturation temperature after the third incremental sluicing. This would result in steam void formation, resulting in a risk of a steam bump. The 12 hour hold period is too short for a 1 foot incremental sluicing. 
Figure 4-1. Tank 241-C-106 Cross-Section, Contents, and Major Dimensions.

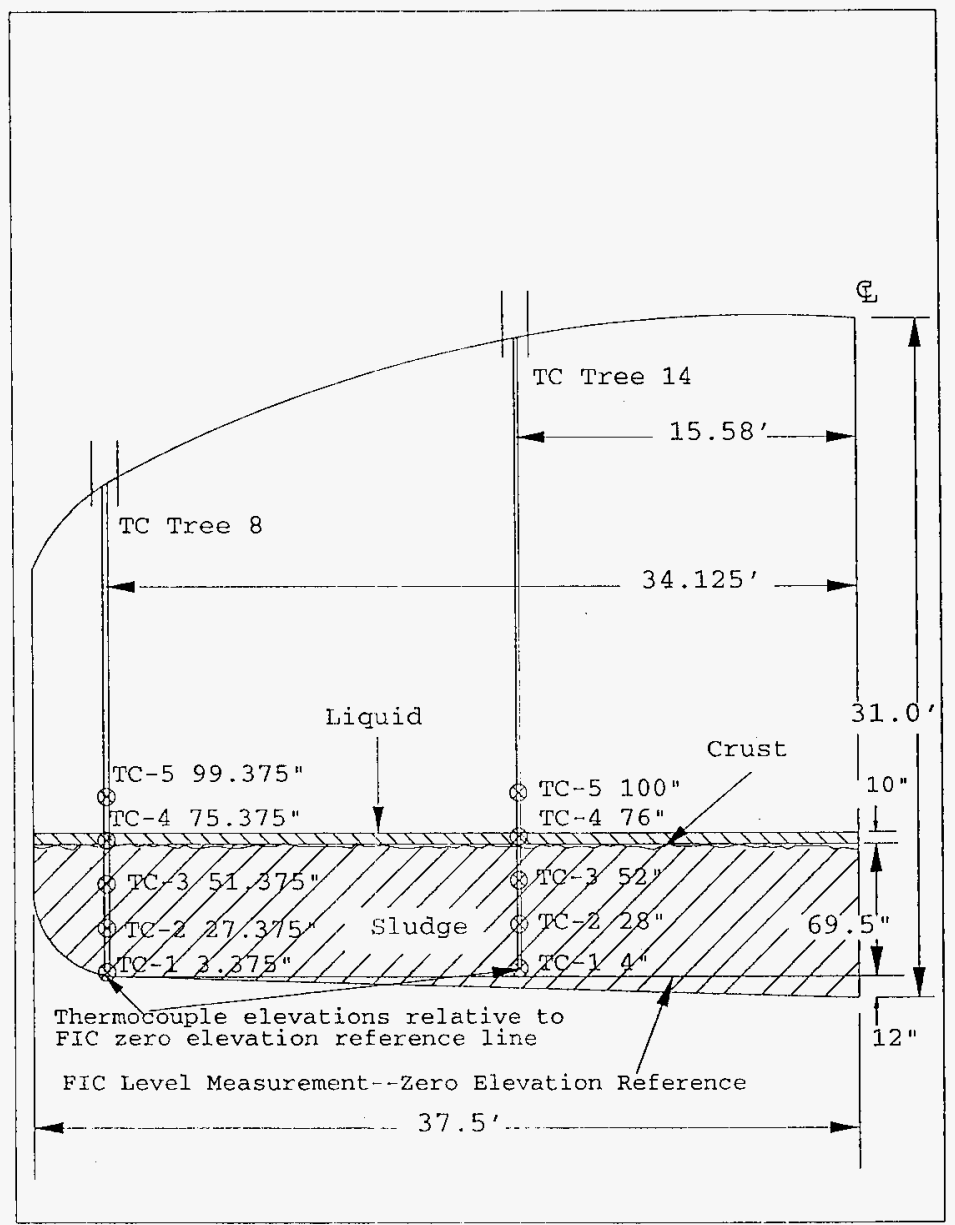


Figure 4-2. Tank 241-C-106 GOTH Sludge Temperature Process Control Model-Dimensions and Computation Node Size.

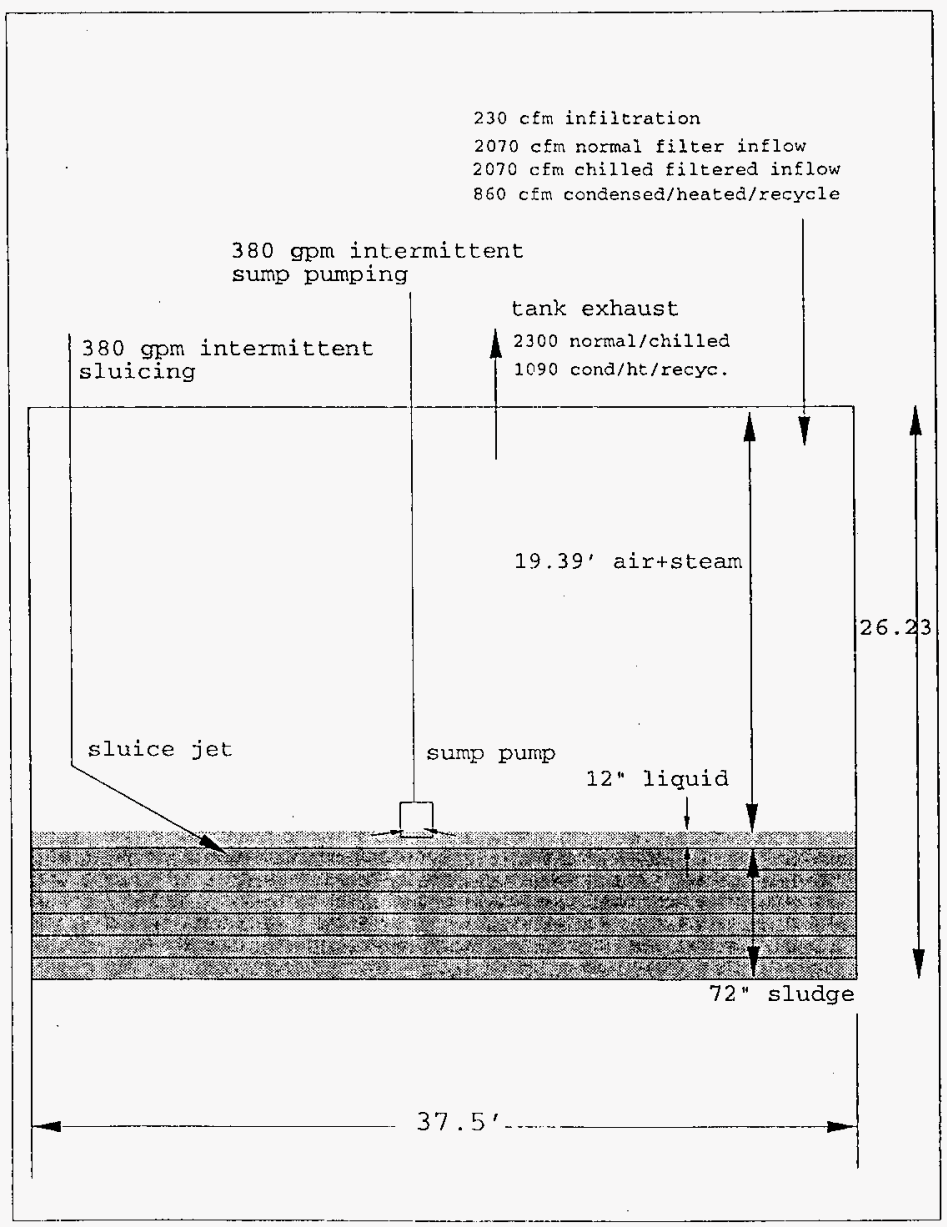


Figure 4-3. Tank 241-C-106 GOTH Sludge Temperature Process Control Model-Boundary Conditions and Time Controlled Conductors.

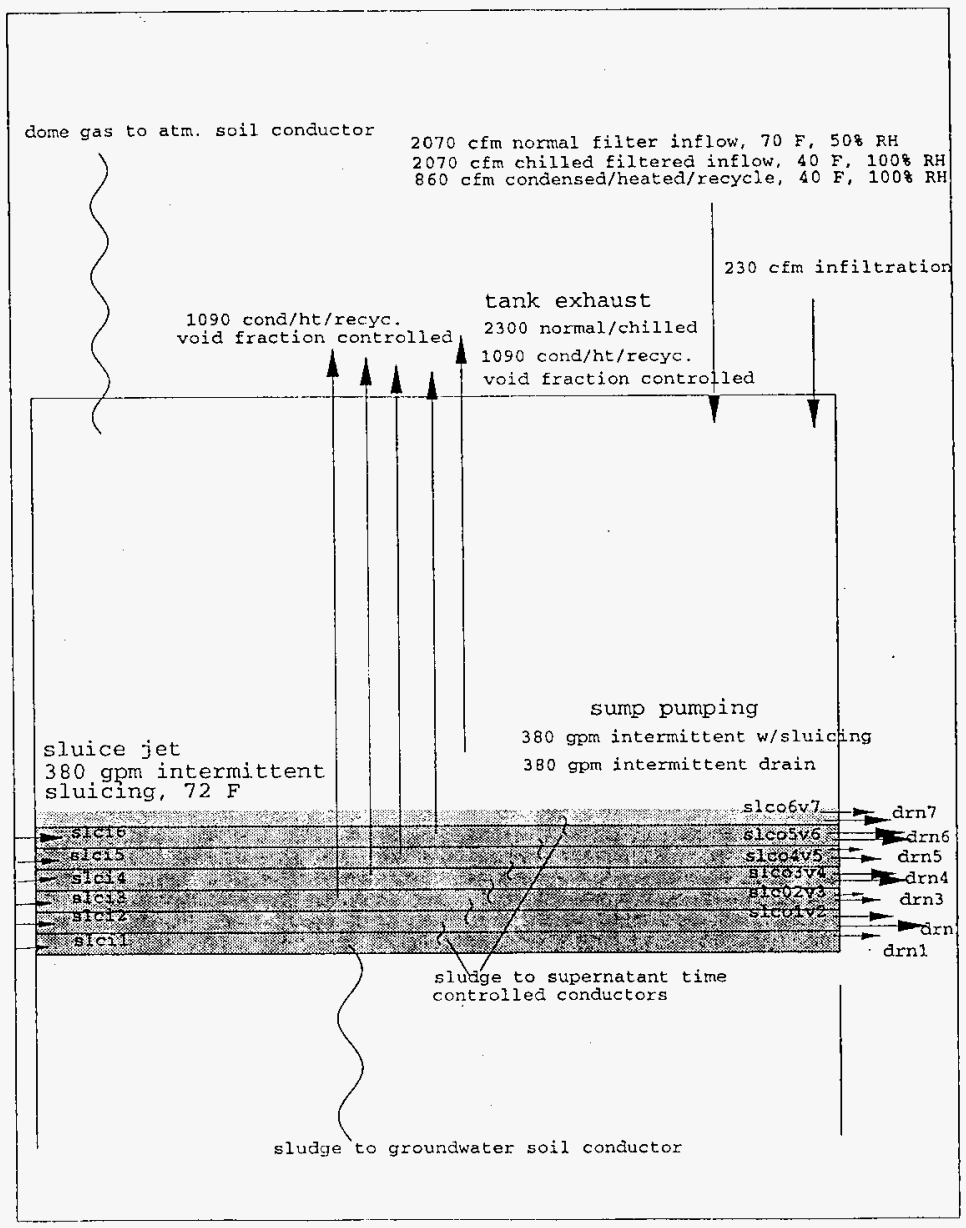


Figure 4-4. Waste Temperature, Level, and Saturation Temperatures vs Time--Short $(12 \mathrm{hr})$ Temperature Control Hold Period.

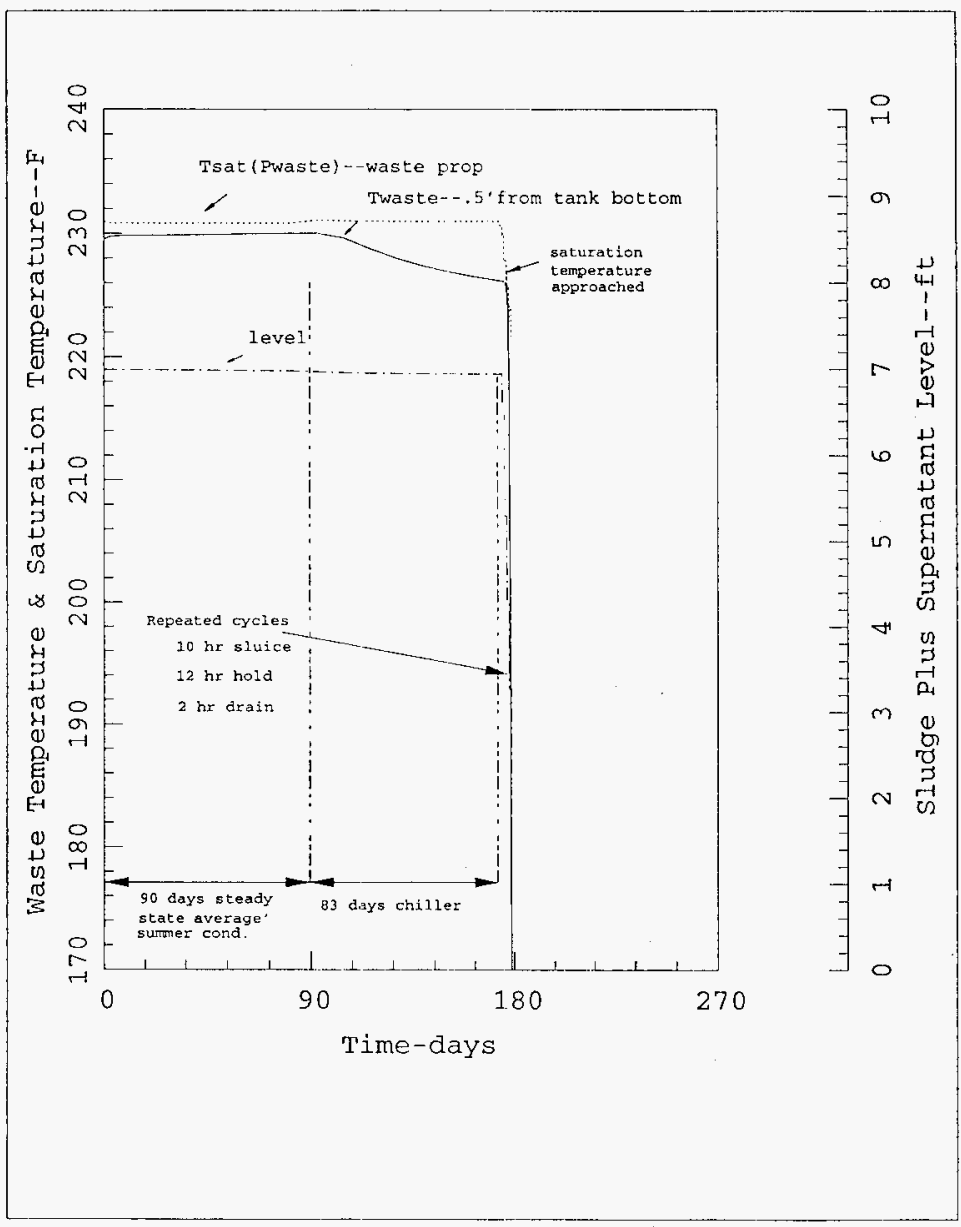


Figure 4-5. Waste Temperature, Level, and Saturation Temperatures vs Time--Short (12 hr) Temperature Control Hold Period-Expanded Time Seale During Sluicing Operations.

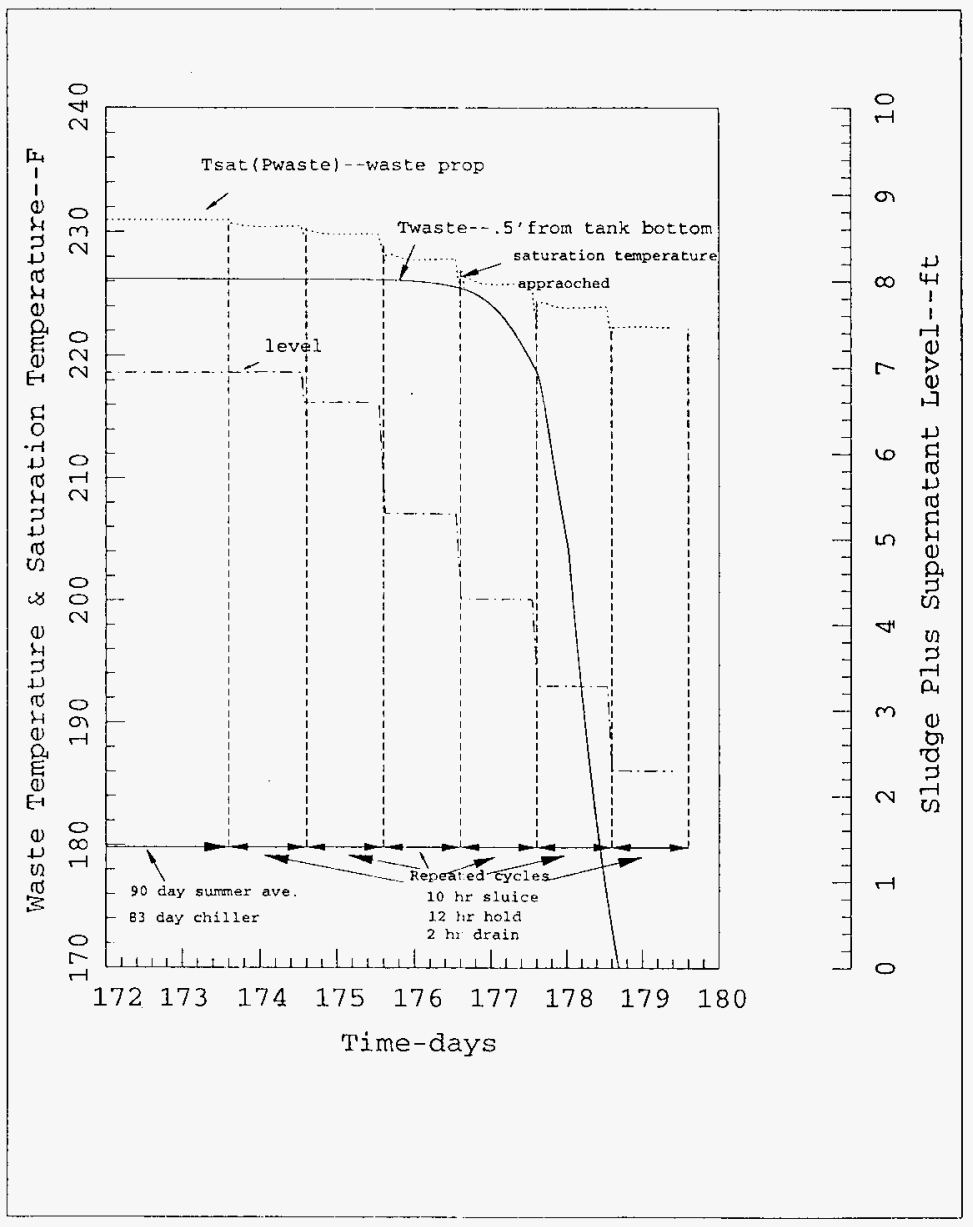




\subsubsection{Long (21 Day) Temperature Control Hold Period.}

A GOTH simulation was performed for a 21 day hold period. All other conditions were the same as the previous analyses. The results in terms of tank bottom waste temperature and pressure, saturation temperature, and waste level are illustrated in Figure 4-6. The difference between saturation temperature and sludge tank bottom waste temperature increases during each sluicing cycle. Based on these results it is clear the hold period can be reduced below 21 days.

\subsubsection{Minimum Required (5 Day) Temperature Control Hold Period.}

A GOTH simulation based upon a 5 day hold period was performed. All other conditions were the same as the previous analyses. The results in terms of tank bottom waste temperature and pressure, saturation temperature, and waste level are illustrated in Figures 4-7 through 4.9. The difference between saturation temperature and sludge tank bottom waste temperature at the end of the chiller operation is maintained during the first sluicing cycle and increases in successive cycles. Based on these results it is clear the hold period should not be decreased below 5 days. Additional hold time would increase the margin of safety.

\subsubsection{Hold Period for Smaller Incremental Sluicing}

The requirement to maintain a constant pool liquid level while sluicing will probably reduce the sluicing efficiency. Based upon past sluicing experience, 6 to $9 \mathrm{inch}$ may be the maximum possible sluicing increment. Analyses are in progress to evaluate these smaller sluicing increments. 
Figure 4-6. Waste Temperature, Level, and Saturation Temperatures vs Time--Long (21 day) Temperature Control Hold Period.

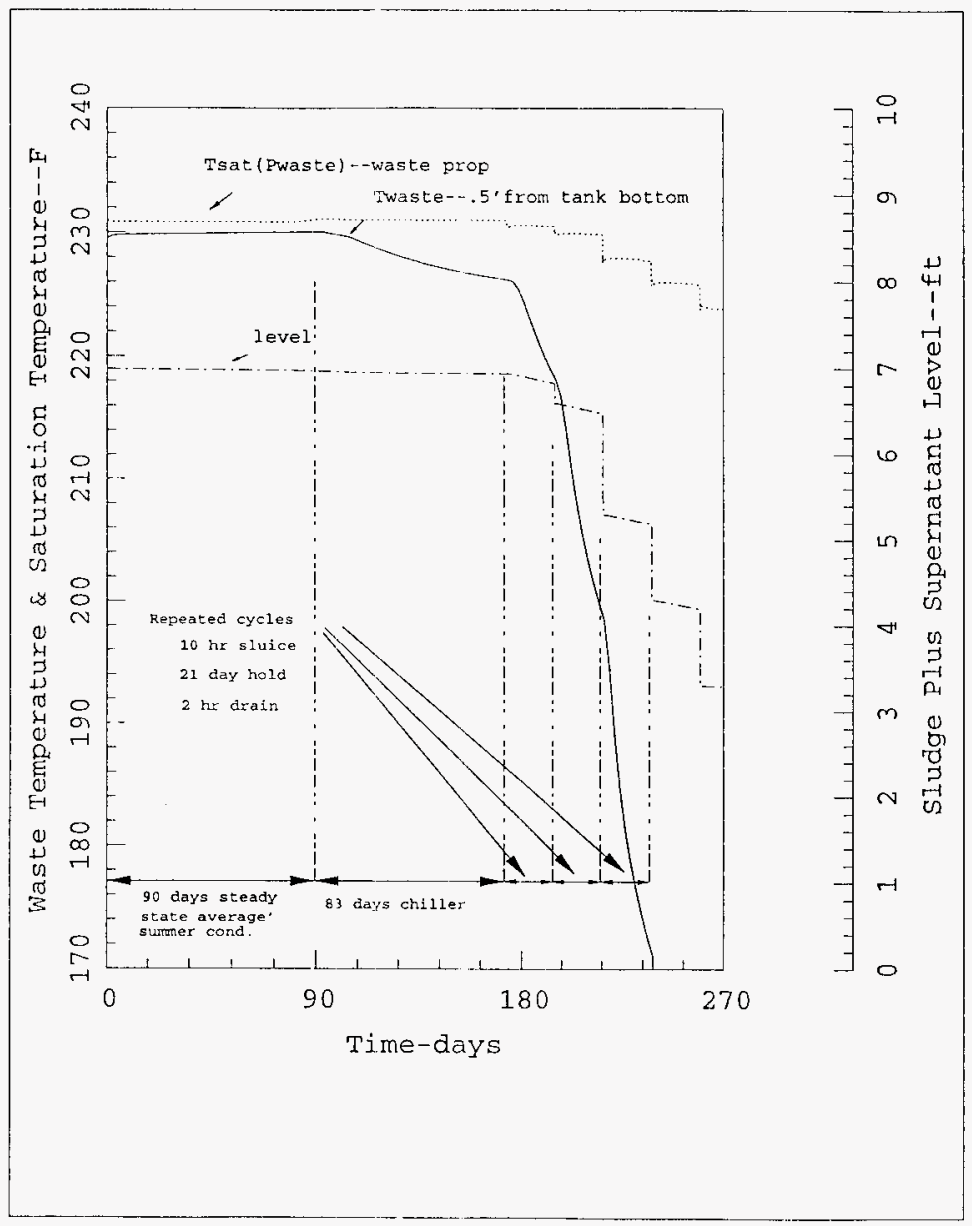


Figure 4-7. Waste Temperature, Level, and Saturation Temperatures vs Time-- 5 day Temperature Control Hold Period.

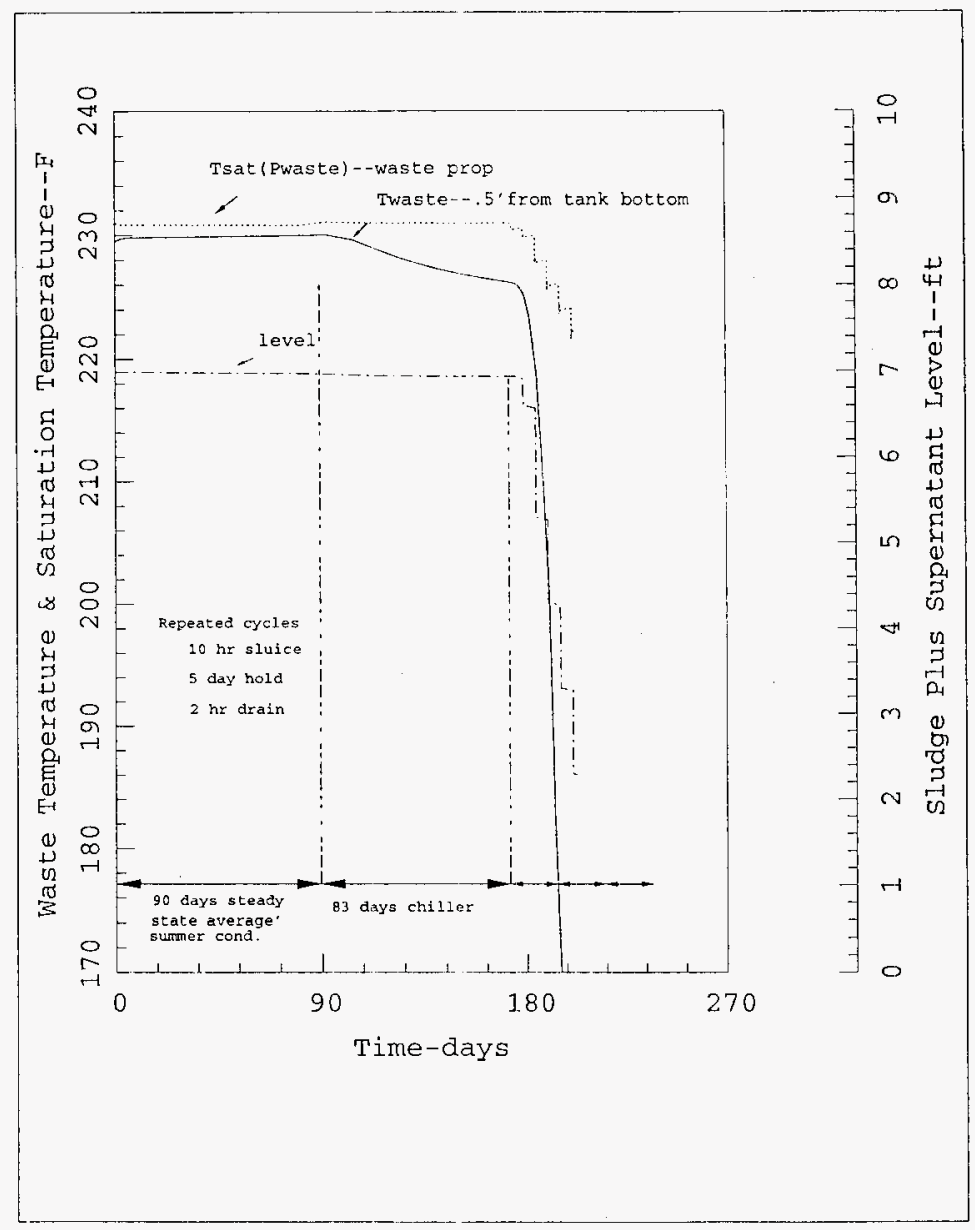


HNF-SD-W320-ER-002, Rev. 0

Figure 4-8. Waste Temperature, Level, and Saturation Temperatures vs Time During Sluicing Operation-- 5 Day Temperature Control Hold Period.

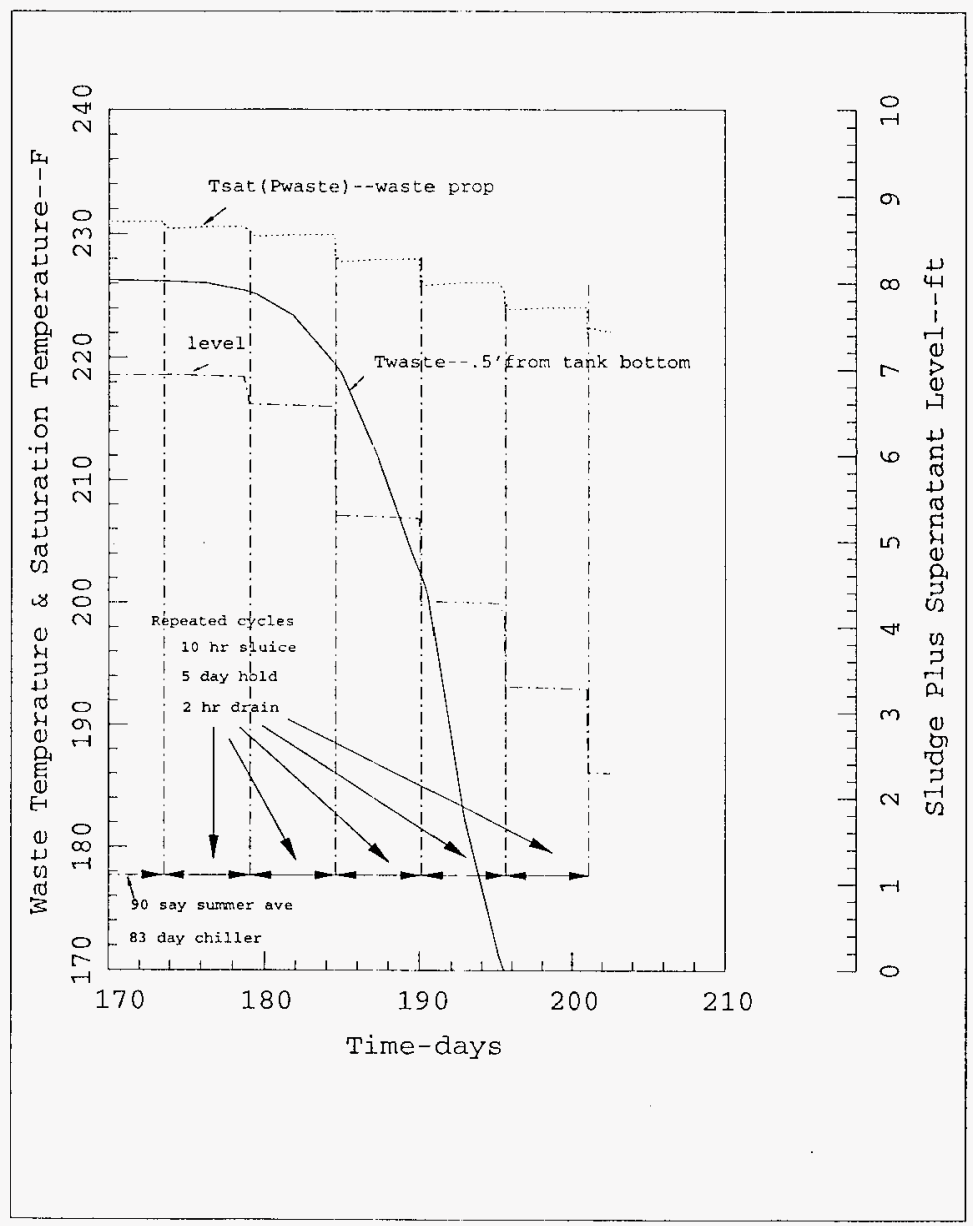


Figure 4-9. Waste Temperature, Level, and Saturation Temperature vs Time During Sluicing Operation- 5 Day Temperature Control Hold Period.

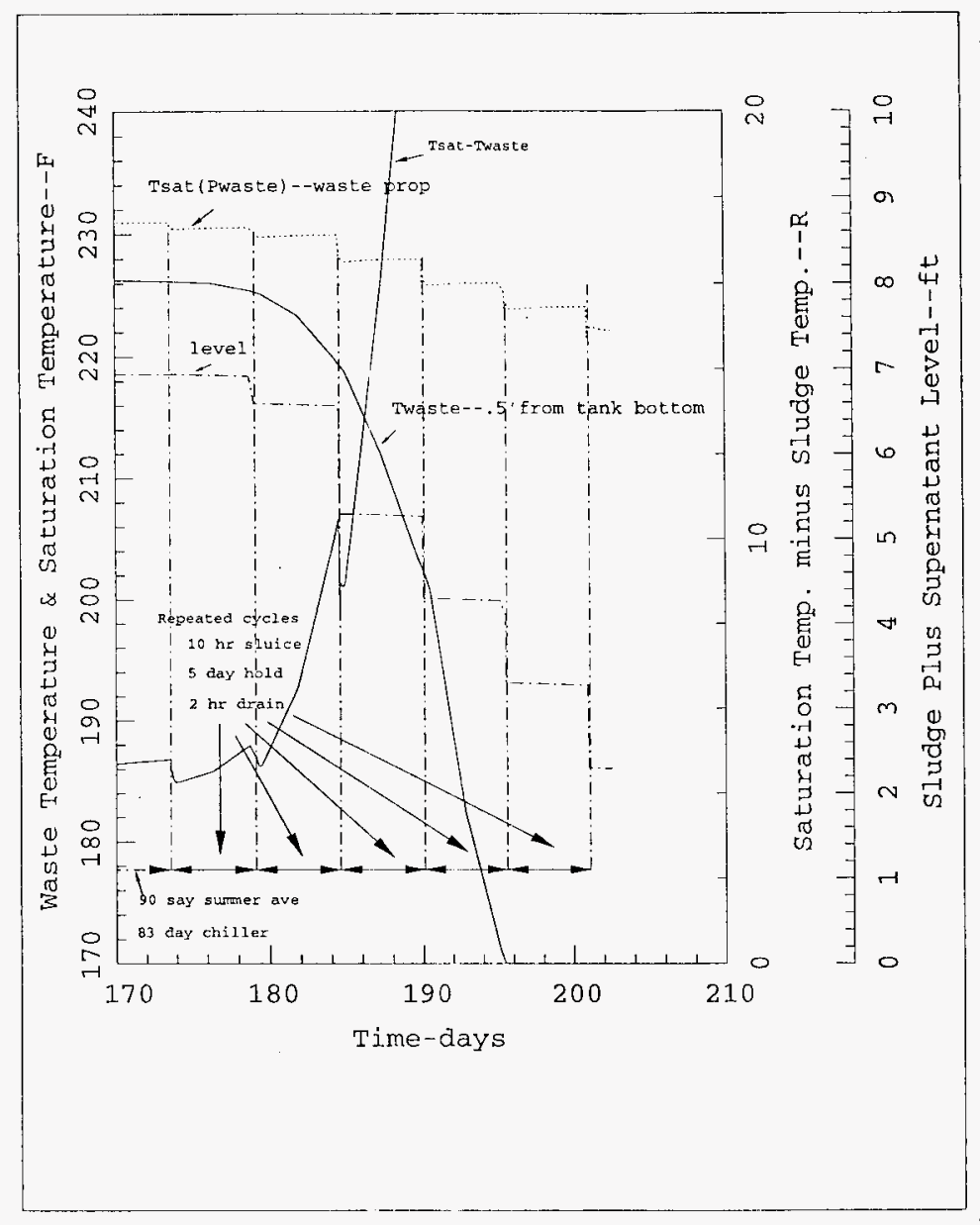


HNF-SD-W320-ER-002, Rev. 0

\subsection{CONCLUSIONS}

The following conclusions were reached as a result of the thermal evaluation of Tanks 241-C-106 and 241-AY-102:

1. The current secondary ventilation system for Tank $241-\mathrm{AY}-102$ will provide only 155 $\mathrm{cfm}$ air flow to the floor channels. The remainder of the total ventilation flow of $\sim 790$ cfm bypasses through the wall annulus.

2. The minimum Project $W-320$ objective of retrieving 2 feet of waste from Tank 241-C-106 does not require the Tank 241-AY-102 annulus ventilation system.

3. Complete retrieval of Tank 241-C-106 will not be possible without modifications to the Tank 241-AY-102 annulus ventilation system and operations requirements.

4. Complete retrieval of Tank 241-C-106 is possible with up to $1000 \mathrm{cfm}$ floor channel flow assuming optimistic values for fluffing factor and tank heat load. The floor channel flow is achievable by blocking the wall annulus flow and operating the secondary annulus ventilation system at high annulus vacuum.

5. Incremental sluicing with mass control and monitoring will provide the necessary temperature control in Tank 241-AY-102.

6. Data monitoring and evaluation combined with transient thermal analyses will allow sluicing to proceed without long delays required to reach thermal equilibrium. It will also maximize the waste transfer from Tank 241-C-106.

7. Adequate subcooling can be maintained in Tank 241-C-106 with pre-sluice chilling of the waste and incremental sluicing with hold periods for subsequent cooling prior to removing hydrostatic head. Computer modeling is required to establish the duration of the hold periods. 


\subsection{REFERENCES}

Babad, H., et. al., Chemical and Chemically Related Considerations Associated with Sluicing Tank C-106 Waste to Tank AY-102, WHC-SD-WM-TI-756, Lockheed Marting Hanford Corp., Richland, Washington.

Bander, T.J., 1993, Revised Thermal History of Tank 241-C-106, WHC-SD-WM-ER-200, Westinghouse Hanford Company, Richland, Washington.

Bander, T.J., Crea, B.A., Ogden, D.M., 1996. Tank 241-C-106 Sluicing Evaluation, WHC-SDWM-ER-588, Rev., 1., Westinghouse Hanford Company, Richland, Washington.

Bendixsen, R. B., 1990, History of Tank Bumps in Aging Waste Tank Farms, WHC-SD-WMTA-021, Rev 0, Westinghouse Hanford Company, Richland, Washington.

Boelter, Gordon, and Griffith, 1946. Rates of Evaporation of Water by Natural Convection, Industrial Engineering Chemistry, 38, 596.

Boyless, V. C., 1996, Operating Specifications for Single Shell Waste Storage Tanks, OSD-T151-00013, Rev. D-10, Westinghouse Hanford Company, Richland, Washington.

Brooks, K.P., Myers, R.L., and Rappe, K.G., 1997, Bench-Scale Enhanced Sludge Washing and Gravity Settling of Hanford Tank C-106 Sludge, PNNL-11432, UC-721, Pacific Nortwest Laboratory, Richland, Washington.

Crane, 1988, Flow of Fluids through Valves, Fittings, and Pipes, Crane Company, Joliet, Illinois.

Crea, B.A., 1996, Resolution of Project W-320 Tier 2, Review Commments, WHC-SD-ER-588, Westinghouse Hanford Company, Richland, Washington.

Conner, J. C., 1996, Safety Assessment for Tank 241-C-106 Waste Retrieval, Project W-320, WHC-SD-WM-SAD-024, DRAFT, Westinghouse Hanford Company, Richland, Washingtion.

Drawing Set 1, H-2-64449, H-2-64307, H-2-64462, H-2-64447, H-2-64448, H-2-77324, H-2-77325, H-2-50704, and H-2-77326, U.S. Department of Energy, Richland, Washington.

Estey, S. D., 1997, Personnel Communication and also recorded in Meeting Minutes \#3, 102-AY Annulus Ventilation System issued by W.J. Powell.

Fryer, B.C. and Thurgood, M.J., Revised Tank Heat Loaed Estimate for the Process Test, JMIWT-002, John Marvin Inc., Richland, WA. 
Lumetta, G.J., Wagner, M.J., Hoopes, F.V., and Steele, R.T., October 1996a, Washing and Caustic Leaching of Hanford Tank C-106 Sludge. PNNL-1131, Pacific Northwest National Laboratory, Richland, Washington.

MacLean, G. T., 1997, Sluiced C-106 Sludge,(cc:Mail Graham T MacLean to John W Bailey, February 12) SGN Eurisys Services Corp., Richland, Washington.

Nordquist, E. M., 1988a, Project B-673, T241-AY-101 Ventilation Tests, (internal letter 24310-88-101 to R. J. Murkowski, September 8), Westinghouse Hanford Company, Richland, Washington.

Nordquist, E. M., 1988b, Project B-673 Air Flow Meeting Minutes, (meeting minutes E. M. Nordquist to Distribution, August 30), Westinghouse Hanford Company, Richland, Washington.

Norton, M.V., 1994b. Personal Commmunication, Battelle Nortwest Laboratory, Richland, Washington.

Powell, W. J., 1985, Double-Shell Tank Annulus Air Flows, WHC-SD-WM-TA-017, Rev. 0, Westinghouse Hanford Company, Richland, Washington.

Public Law 101-510, Section 3137, 1990, Safety Measures for Waste Tanks at Hanford Nuclear Reservation, U. S. Congress, Washington, D. C. [Also referred to as the Wyden Amendment]

Reynolds, D. A., 1997, Fluffing Factor, (cc:Mail Dan Reynolds to K. Sathyanarayana, February 6), Lockheed Martin Hanford Corp., Richland, Washington.

Sathyanarayana, K., and B. C. Fryer, 1996a, Evaluation of Potential and Consequences of Steam Bump in High Heat Waste Tanks and Assessment and Validation of GOTH Computer Code, WHC-SD-WM-CN-022, Rev. 0, Westinghouse Hanford Company, Richland, Washington.

Sathyanarayana, K., and B. C. Fryer, 1996b, Thermal Hydraulic Evaluation of Consolidating Tank C-106 Waste into Tank $A Y-102$, WHC-SD-WM-ER-534, Rev. 0, Westinghouse Hanford Company, Richland, Washington.

Schreiber, R. D., J. G. Douglas, R. D. Cromar, T. L. Welsh, and B. C. Simpson, 1996, Tank Characterization Report for Single-Shell Tank 241-C-106, WHC-SDWM-ER-615, Westinghouse Hanford Company, Richland, Washington.

Tardiff, G., 1995a, AY-102 Annulus Exhauster, (cc:Mail Gary Tardiff to K. Sathyanarayana, August 30), Westinghouse Hanford Company, Richland, Washington.

Tardiff, G., 1995b, AY-102 Annulus Exhauster, (cc:Mail Gary Tardiff to 
John Conner, September 21), Westinghouse Hanford Company, Richland, Washington.

Thurgood, M. J., et al., 1993, GOTHIC Containment Analysis Package, Version

3.4e, EPRI TR-103053, Electric Power Research Institute, Palo Alto, California.

WHC-SD-WM-BIO-001, Rev E, Tank Waste Remediation System Basis for Interim Operation, September 1996 .

Zigrang, D. J., and N. D. Sylvester, 1985, "A Review of Explicit Friction

Factor Equations," Transactions of the ASME, Vol. 107 
HNF-SD-W320-ER-002, Rev. 0

APPENDIX A Internal Memo, E. M. Nordquist to R. J. Murkowski, "Project B-673, T241AY-101 Ventilation Tests, dated September 8, 1998. 


\section{HNF-SD-W320-ER-002, Rev. 0}

(This page intentionally left blank.) 
HNF-SD-W320-ER-002, Rev. 0

(2) Westinghouse

Ficm: Tank Farms Projects

Fhone: $\quad 3-4289$ R3-38

Date: $\quad$ September 8,1988

SUbject: PROJECT B-673, T241-AY-101 VENTILATION TESTS

Tc:

R. J. Murkowski

$\begin{array}{ll}\text { cC: S. I. Anderson } & \text { R3-09 } \\ \text { T. E. Arndt } & \text { S2-02 } \\ \text { G. L. Borsheim } & \text { R2-11 } \\ \text { F. E. Boyd } & \text { S5-04 } \\ \text { T. A. Carlson } & \text { R1-51 } \\ \text { G. L. Dunford } & \text { R1-51 } \\ \text { K. O. Fein } & \text { R1-51 } \\ \text { L. R. Hail } & \text { S1-54 } \\ \text { D. G. Harlow } & \text { R2-01 }\end{array}$

$R 2-93$

R3-09 D. E. McKenney R2-11

C. B. McVey R2-93

J. A. Neely R3-38

G. L. Parsons D/P R3-38

W. J. Powell R2-11

J. C. Homack R2-18

R. M. Ybarra , R2-93

EMN: File/LB

Reference: DSI, R. J. Murkowski to G. L. Parsons, same subject, September 2, 1988

The referenced DSI (copy attached) requested Tank Farm Projects to remove the bianks installed on the air inlets supplying air to the sides of Tank $241-A Y-101$, and adjust the flow to $950 \mathrm{CFM}+1-21 \%$ without balancing any of the individual flows. Attached is a summary of the results in tabular form and a copy of the field results. Based on the DSI, the project has resumed construction, backfilling the excavations and welding the test ports. All project activities should be completed by September 30, 1988.

\section{Emhandyingt}

E. M. Nordquist, Project Engineer 


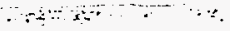

DON'T SAY IT - WRITE ITI

TO:

G. L. Parsons R3-38

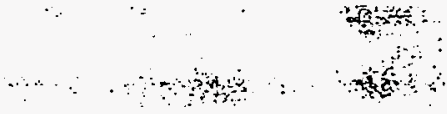

DATE: Septeaber 2, 1988

FROH: R. J. Murkowskif R2-93

SUBJECT: PROJECT B-673, T241-AY-j101 VENTILATION TESTS

Results of air flow balancing tests for the subject tank have been reviewed by Defense Haste Management Systems Engineering. After consideration of a)ternatives, the engineering organization has decided that to minimize impacts to the overail tank ventilation system and operating conditions of the AY Tank Farm, the annulus ventilation system of Tank 101-AY should be returned to as near previous operating condition as is possibie. Additional analysis to optimize the system for providing early leak detection will be undertaken separately from project actfuities thus allowing completion of construction.

Therefore, you are requested to remove the blank orifice plates from the four 6-inch inlet ports that encircle and penetrate the annular wall of the secondary tank. Flow testing should be repeated to adjust exhaust stack flows to the original design requirement of 950 CFH $\pm 21 \%$ while maintaining the annulus pressure differential of not less than 0.5 inches of WG between the primary and secondary tanks. The orifice plates installed during previous air flow balancing on the six outlet exhaust ports are not required to be removed provided all: other conditions of air velocity and pressure differential values are achéved.

Tes $\bar{t}$ ail air hows without attempting additional balance of the system. Record all air flows to within $\pm 2 \%$ and include recorded data of temperature and vacuum readings at specific locations. Please provide copies of the test results to Mr. H. J. Powell upon conclusion of air flow testing.

$\operatorname{srr}$

CC: S. I. Anderson R3-09

T. E. Anndt $\mathrm{S} 2-02$

G. L. Borsheim R2-11

T. A. Carlson RI-51

G. L. Dunford R1-5I

K. 0. Fein R1-51

L. R. Hall $\$ 1-54$

D. G. Harlow R2-0I

D. E. Hckenney R2-11

C. B. HoVey R2-93

J. A. Neely R3-38

E. H. Nordquist R3-38

W. J."Powell . R2-11'

J. C. Womack R2-18

R. H. Ybarra R2-93

RuH LB/File 
ReR 9/8/88

Final Test a/4/5s
PAGE 4 OF 6

2.2 wh Tank

0.5 ! wo, Annum

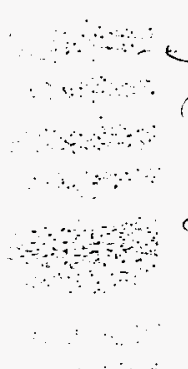

Intets jum

$855 \mathrm{~cm}$

Eximent-sum Exto

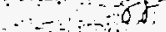

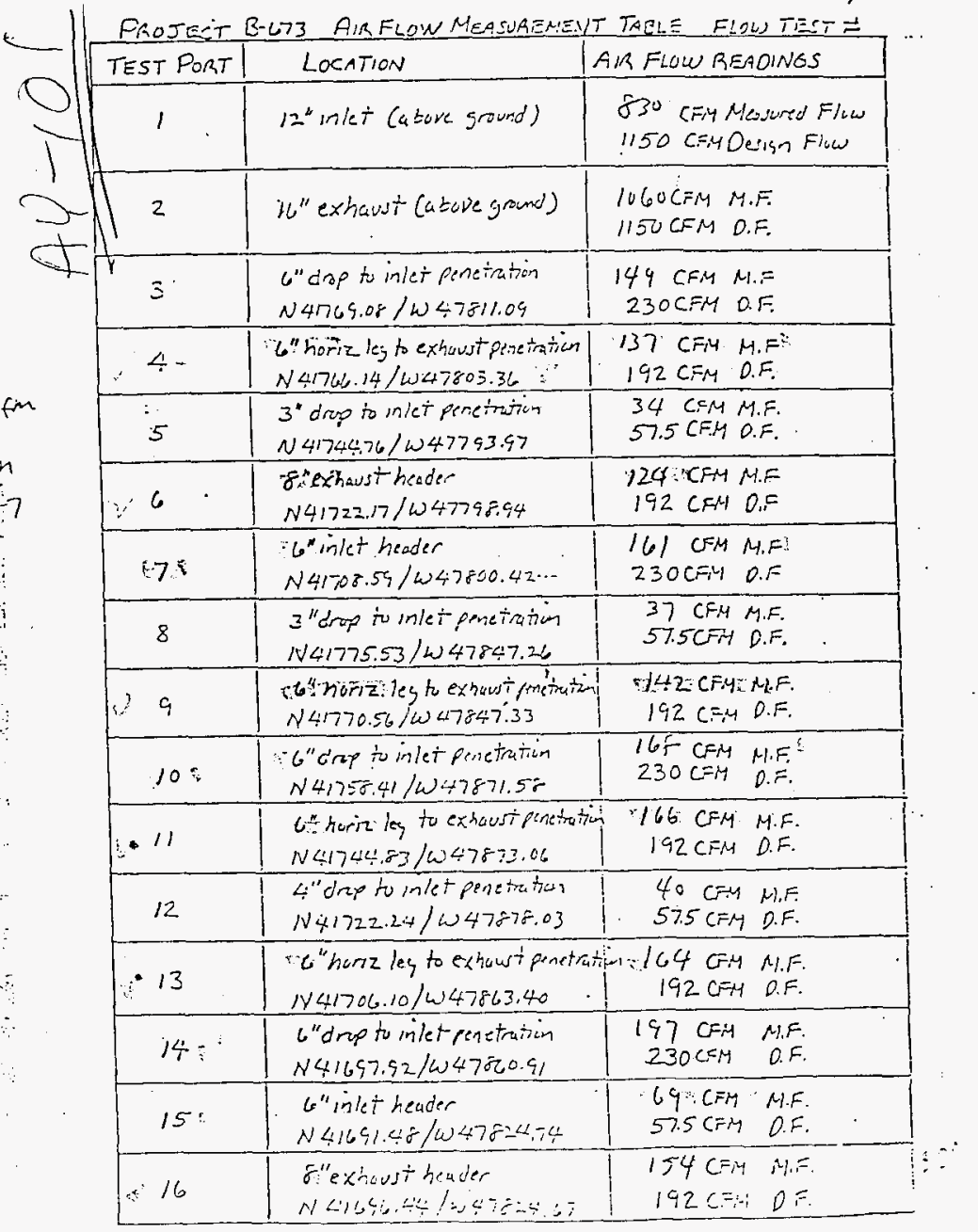

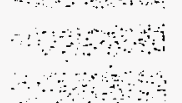

$\because \because$

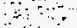

$B-L>3$ 
B-673 AIR FLOW BALANCING TEST PLAN

Final Test a/2/85

PAGE \& OF 6

2.2 wh Tank

0.51 wo, Anaw

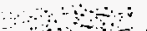

$\ldots$

का

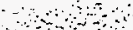

a n

$\because$

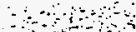

$\because-2$

$\therefore \therefore$

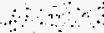

Irlets sum

$8556 \mathrm{fm}$

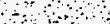

Chaustosom

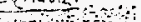

- $57 \mathrm{~cm}$

an

$\therefore-\mathrm{s}$

$\therefore$

PROJECT BLT3 AMELOW MEASUAEMENT TARLE FLOW TEST

TEST PORT ILCATION IAR FLUW REAOINGS

\begin{tabular}{|c|c|c|}
\hline 1 & $12 "$ inlet (atove ground) & $\begin{array}{r}830 \text { (Fit Mosurd Flia } \\
\text { CFMDersn Fluw }\end{array}$ \\
\hline
\end{tabular}

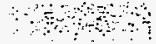

$\therefore$

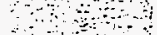

$\because ?$

$\because$

$\therefore<$

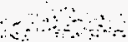

$\therefore \%$

an

10

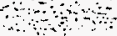

$a$

\begin{tabular}{|c|c|c|}
\hline 2 & $\begin{array}{l}\text { il" exhaut (acive gaimat) } \\
\text { STACK Exisust }\end{array}$ & $\begin{array}{r}\text { IU GOCFM M.F. } \\
\because \text { CFM O.F. }\end{array}$ \\
\hline$=$ & G"drop to inlet pene & 144 CFM M.E \\
\hline
\end{tabular}

$7 \mathrm{cfm}$

\begin{tabular}{|c|c|}
\hline & $N 4764.08 / \omega 47811.04$ \\
\hline $4^{-}$ & $\begin{array}{l}6^{\prime \prime} \text { hor:z lej to exhoust penetimition } \\
N 41766.14 / W<7803.36\end{array}$ \\
\hline 5 & $\begin{array}{l}3^{4} \text { drap to mict penciration } \\
N 4174476 / \omega 47743.47\end{array}$ \\
\hline
\end{tabular}

\begin{tabular}{|c|c|c|}
\hline 6 & $\begin{array}{l}8^{n} \text { exhaust header } \\
N 41722.17 / \omega 47798.94\end{array}$ & $\begin{array}{l}124 \text { CFH M.F } \\
\because \text { CFIH O.E }\end{array}$ \\
\hline 7 & $\begin{array}{l}6^{11} \text { inkt heoder } \\
\text { N41708.59/w478500.42 } .\end{array}$ & $\begin{array}{l}\text { 16) CFM M.F } \\
\text { CFI-1 O.F }\end{array}$ \\
\hline 8 & $\begin{array}{l}3 \text { "drop in miet pmetration } \\
\text { N41775.53/w47847.26 }\end{array}$ & $\begin{array}{l}37 \text { CF.H M.F. } \\
\text {-CFH D.F. }\end{array}$ \\
\hline
\end{tabular}

\begin{tabular}{|c|c|c|}
\hline & $N 41775.53 / \omega 47847.26$ & . LAT D.F. \\
\hline 9 & $\begin{array}{l}6^{\prime \prime} \text { hurre. leg to exhawst/mstimation } \\
N 41770.56 / \omega 47847.33\end{array}$ & $\begin{array}{r}142 \text { CFM M.F. } \\
\text { CFH D.F. }\end{array}$ \\
\hline 10 & 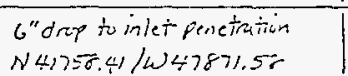 & $\begin{array}{l}\text { 16. CFH M.F } \\
-\therefore C F H \text { D.F. }\end{array}$ \\
\hline
\end{tabular}

\begin{tabular}{|c|c|c|}
\hline 11 & $\begin{array}{l}\text { " heriz le to exhoustpentingtion } \\
N 41744.83 / \omega 47872.06\end{array}$ & $\begin{array}{l}166 \text { CFM M.F. } \\
\because \text { CFM D.F. }\end{array}$ \\
\hline 12 & $\begin{array}{l}\text { 4"drap to inlet penctiation } \\
N 41722.24 / \omega 47 \text { fro.03 }\end{array}$ & $\begin{array}{l}40 \text { CIM H.F. } \\
\text { CFM D.F. }\end{array}$ \\
\hline
\end{tabular}

\begin{tabular}{|c|c|c|}
\hline 13 & $\begin{array}{l}\text { 6"horiz les to exhourt penet } \\
1041706.10 / \text { w } 7863.40\end{array}$ & $\begin{array}{r}\text { lC4 GFM M.F. } \\
: C F M \text { D.F. }\end{array}$ \\
\hline 14 & $\begin{array}{l}\text { G"drop to inletpenetraisin } \\
\text { N41657.92/W47060-9/ }\end{array}$ & $\begin{array}{r}197 \text { CFM M.F. } \\
\text {-iCEM O.F. }\end{array}$ \\
\hline 15 & $\begin{array}{l}\text { G"inkt header } \\
N 4164145 / \omega 47824.74\end{array}$ & $\begin{array}{l}\text { CG CFM M.F. } \\
\therefore C F M \quad O F .\end{array}$ \\
\hline 16 & 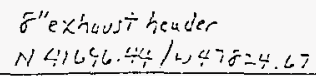 & $\begin{array}{l}154 C=H \quad \therefore= \\
\therefore \quad C=-D F\end{array}$ \\
\hline
\end{tabular}

mon 
$P_{g} /$ of $2 p g$

$$
\text { 24l-Ay Fow Survey }
$$

$$
9-6-88
$$

101-9y Annulus flow meascurements:

Frti Mian Inlet .7854

$.072 \quad 1075$

1,731082

$1,24 \quad 1059$

171060

$.068 \frac{1045}{5351}$

.0681045

$.075 \quad 1097$

Pretitter OPP.06 wis.

.0771111

fifer \&P dowig.

$.066 \quad 1029$

$.054 \frac{932}{5213}$

A.g. $1056 \mathrm{FFM}=830 \mathrm{cFm}$
PT"2 stack Exhaust 1.227ש

$.095 \quad 1254,013 \quad 457 \quad 1053 \quad 922 \quad 05 \quad 896 \quad$ Primary filfer off iswig,

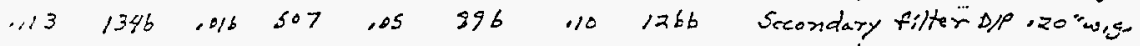

107 $1060 \quad 028670 \quad 037 \quad 770 \quad 093 \quad 1222$ Exhaust Damper 3070 open.

$.649 \quad 887 \ldots .01 \quad 400 \quad 1032 \quad 716 \quad 1079 \quad 1119$ Finlet Temp 65\%

A $28.8679=6,060 \mathrm{cFm}$

$P T=3 \%$ Iulet 1964 ש

$.034 \quad 735 \quad .841811$

$.039 \quad 791 \quad 1037 \quad 770$

$1039 \quad 791 \therefore \quad 10=9682$

i. 79 79 .032 716

.611 $\frac{811}{3.722} \quad 1029 \frac{692}{3661}$

$\therefore 2 g .758 \quad F P M=149 \mathrm{cfm}$
PT:A4 Exhaust .1964

$.026 \quad 645 \quad 031765$

$\begin{array}{llll}.032 & 7 / 6 \quad 1032 \quad 7 / 6\end{array}$

$.032 \quad 716 \quad 031 \quad 705$

$1039 \quad 716 \quad 1028 \quad 670$

$.032 \frac{716}{3509} 1029 \frac{68 z}{3478}$

Avg. 699 FPM $=137<F m$

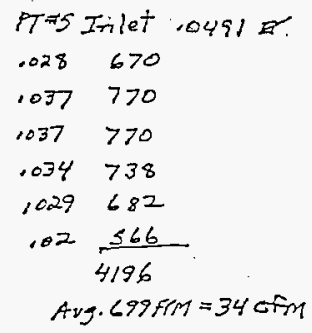


wi-gry ANomlus Con'T

\begin{tabular}{|c|c|c|c|}
\hline $00 ?$ & 335 & .009 & 380 \\
\hline 007 & 335 & 1009 & 380 \\
\hline od & 310 &, 01 & 400 \\
\hline$=09$ & $\exists 80$ & .007 & 3.35 \\
\hline & 358 & 1007 & 335 \\
\hline & & & 1830 \\
\hline
\end{tabular}

AvG. $355 \mathrm{FPM}=124, \mathrm{ctm}$

$T=9$ Exhaustimi964\%

$.031705 \quad 038750$ :

D:5 $749 \quad .37 \quad 770$

$.038 \quad 790 \quad 1034 \quad 738$

$.04 \quad 801 \quad 021580$

$.037 .770 \quad .021 \leq 58$

3805

3448

$\therefore \% .725$ FPM $=7 \% 2 \mathrm{CF}$

$: 7 \% / 2 I_{n / 67} .0873$

.013457 .015 491

iell $420 \quad 1014 \quad 474$

Eit $474^{\prime}, 014 \quad 474$

$015 \quad 491 \quad 012 \quad 439$

.215 491. $10114=2$

$2333 \quad 2298$

ARE. $463 \mathrm{FPM}=40 \mathrm{cFM}$

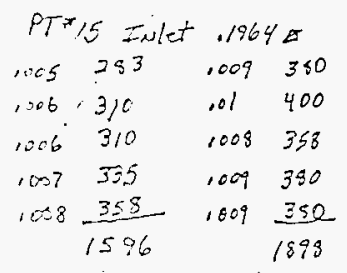

$A, 349 \angle P M=69 \mathrm{cFm}$ $\rho_{9} 2$ of $2 \rho_{9}$

$\begin{array}{llll}\text { PTF } 7 \text { Inlet } & .1964 \text { E } \\ .031 & 705 & .051 & 904 \\ .038 & 780 & .051 & 904 \\ .046 & 859 & .049 & 887 \\ .047 & 868 & 1035 & 749 \\ .047 & \frac{868}{4080} & .03 & \frac{694}{4138} \\ \text { Arg. } 821 \mathrm{FHm} & =161 \mathrm{cfm}\end{array}$

$\begin{array}{ll}\text { PT } & \text { Iwlet .0491 E } \\ .025 \quad 633 \\ .026 \quad 645 \\ .042 \quad 821 \\ .045 \quad 849 \\ .041811 \\ .035 \frac{749}{4508}\end{array}$

ing. $751 \mathrm{FPM}=37 \mathrm{cFr}$

- prt10 Iulet .1964\& : PT"ll Exhaust $1964 \%$

$\begin{array}{llllllll}.039 & 791 & .051 & 904 & .04 & 801 & .047 & 868\end{array}$

$\begin{array}{lllllllll}.041 & 811 \quad 1052 & 913 & 041 & 811 \quad 1048 \quad 877\end{array}$

$\begin{array}{llllllllll}1045 & 849 & 1048 & 877 & 1046 & 859 & 1049 & 887\end{array}$

$\begin{array}{lllllllll}.047 & 865 & .044 & 840 & .046 \quad 859 \quad 1044 \quad 840\end{array}$

$.049 \frac{887}{4206} \quad 104 \frac{811}{4345} \quad .046 \frac{859}{4189} \quad 1039 \frac{781}{4263}$.

Avg. 855 Fin $768 \mathrm{crm} \quad$ Avg, $845 \mathrm{FPM}=166 \mathrm{cFm}$

PTith: Exhawst "1964 B

$.041811 \quad 047 \quad 868$

$1041811 \quad 047 \quad 868$

$1043 \quad 931 \quad 348 \quad 877$

$1046 \quad 49 \quad 1043 \quad 831$

$1047 \frac{\$ 48}{4180} \quad 1033 \frac{727}{4171}$

Avg. $835 \mathrm{FPM}=164 \mathrm{cfm}$

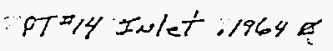

$.053 \quad 922 \quad .0651020$

$.061 \quad 959^{\circ} 1067 \quad 1037$

$\begin{array}{llll}1061 & 959 \quad .063 \quad 1004\end{array}$

$1071 \quad 1067 \quad .061 \quad 989$

$1067 \frac{1037}{5004} \quad .057 \frac{956}{5006}$

Aug, $1001 \mathrm{APH}=197 \mathrm{cfm}$

PT*16) Exhaust , 3491

$.007 \quad 335 \quad .013 \quad 457$

$\begin{array}{llll}1009 & 380 \quad .015 \quad 491\end{array}$

Total Ait Flow Exhaus $887 \mathrm{cfm}$

$101400 \quad 1014 \quad 474 \quad$ Inst. s/N 4667

.012439 10/5 491

$1013 \frac{457}{2011} \cdot 1014 \frac{474}{2387}$

Arg. 440 FPM $=154$ ctin

Takew by,

carrick thoptis : Ward : 
HNF-SD-W320-ER-002, Rev. 0

APPENDIX B Meeting Minutes, Project B-673 Air Flow, August 30, 1988. 
HNF-SD-W320-ER-002, Rev. 0

(This page intentionally left blank.) 





Qutline of the test is as follows:

GL $8+888$ 1. Measure ambient WB/DB temperatures.

$4 x<1880$ 2. Adjust the fan to $1150 \mathrm{CFM}$.

4 1 81888 3. Record the annulus $d p$ and the tank $d P$. Verify the delta between the annulus and tank is at least $0.5^{\prime \prime}$ W.g.

- The annulus $d P$ may be recorded from the magnehelic gauge located on riser $17 \mathrm{E}$, and the tank $d P$ may be recorded from riser 150. Both numbers may also be obtained from a 3-pen strip recorder in 241-AY-801 Building.

Annulus dP 0.7 "w.g. Tank dP 1.8"w.g. Delta 1.1" w.g.

Note: Allowable range of annulus $d P$ is $-1.5^{n}$ to $-0.5^{n}$ W.g.

Ge $8-19.86$ 4. Measure the velocity at all 16 test ports, the pitot readings taken along a straight line through the center.

- For the 3" lines, take 6 pitot readings.

- For the 4", 6", 8", 12", and 16" lines, take 10 pitot readings.

(Refer to page 3 for distances of pitot placement, page 4 for recording CFM's, and page 6 for test port layout.)

Uht 8-19-88 6. Start blanking the four 6" inlet lines, one or two at a time, while maintaining the $1150 \mathrm{CFM}$, and monitor the annulus dP. Stop blanking the lines. when the annulus dP raches $-1.5^{n} \mathrm{w} .9$. Reduce the flow and continue to blank the lines until all four lines are blanked and the annulus $\mathrm{dP}$ is $-1.5^{\mathrm{n}} \mathrm{W} . \mathrm{g}$. Record the total exhaust flow and notify W. J. Powell on 3-3296 or G. L. Borsheim on 3-225I of the final flow.

Annulus dP 1.5 "w.g. Tank dP 2.6 "w.g. Delta l.1"w.g.

Total flow $577 \mathrm{CFM}$ ( 550 on $\mathrm{FI}-\mathrm{KI}-1-1$ )

Q1 -8-29-88 7. If the final flow is less than $200 \mathrm{CFM}$, stop work. If the flow is greater than 200 CFM, balance each of the exhaust flows to within $+1-10 \%$ of the total flow divided by six. Record the flows here and on page 5 . shering for 46 CFM

Test port \#4 BO CFM Test port $\# 11$ \&6 CFM 512 an

Test port 46 90 CFM Test port $\frac{413}{86}$ CFM

Test port $\# \frac{82}{252} \mathrm{CFM}$ Test port $\pi 16 \frac{88}{260}$ CFM

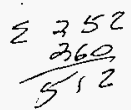


HNF-SD-W320-ER-002, Rev. 0

-3.573 AIR FLOW BALANCING TEST PLAN

PAGE 2 OF 6

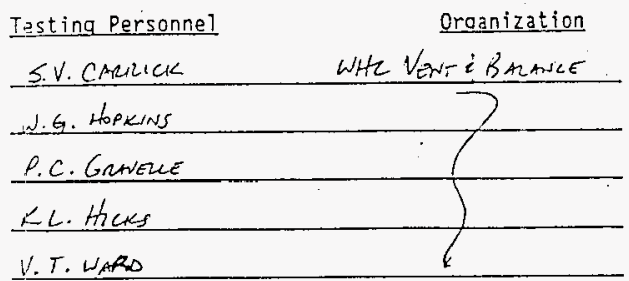

Equioment and tad/serial/calibration number

Neomanias ELcomonic DiGital Micno-manometer soun 4667 
B-673 AIR FLON BALANCING TEST PLAN

$9-6$

RDUSTRUAL VEATILATION

TABLE $9-1$.

TABLE $9-2$

PAGE 3 OF 6

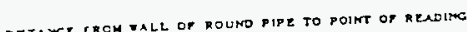

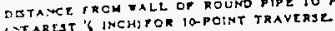

\begin{tabular}{|c|c|c|c|c|c|c|c|c|c|c|}
\hline cLET & {$\left[\begin{array}{c}1 \\
0.025 \\
0.4\end{array}\right.$} & \begin{tabular}{|c|c|}
$x_{2}$ & 8 \\
0.002 & 0 \\
0.4 & 0 \\
\end{tabular} & \begin{tabular}{l|l}
8 & $\pi$ \\
0.146 & 0. \\
0 ois & \\
\end{tabular} & \begin{tabular}{|l|l|}
$x$ & $x_{1}$ \\
0.230 & 0.5 \\
0 & 0 \\
\end{tabular} & 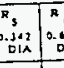 & 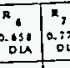 & \begin{tabular}{l|l|}
$x_{1}$ & $x_{2}$ \\
0.3 & 0.15 \\
0 & 0.4 \\
\end{tabular} & 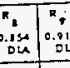 & 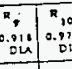 & $\begin{array}{l}710 \\
0.914 \\
0+4\end{array}$ \\
\hline 4 & 6 & 1 & 3 & 3 & 14 & $2 \%$ & 346 & 34 & $3 \xi$ & 34 \\
\hline 4 & 3 & 4 & $1 \%$ & 1 & $1 \%$ & 3 & 3's & $34^{\prime}$ & 44 & 44 \\
\hline 5 & $\%$ & 4 & 1 & $1 \%$ & $1 \%$ & $3 \%$ & د'6 & $4 \%$ & 45 & 43 \\
\hline S'4 & $\%$ & 3 & $y_{4}$ & $1 \%$ & $1 \%$ & 3" & $4 \%$ & 44 & 5 & 53 \\
\hline 6 & 16 & 14 & $\because$ & 14 & 2 & 4 & 4 & 54 & 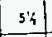 & $5 \%$ \\
\hline 7 & 3 & ᄂ & 1 & $1 \%$ & 24 & $4 \%$ & S15 & 6 & 68 & 614 \\
\hline 8 & $\%$ & $\ddot{\prime \prime}$ & $1 \%$ & $1 \%$ & $2 \%$ & $5 \%$ & $6 \%$ & $6 \%$ & 74 & $7 \%$ \\
\hline 9 & $\%$ & $\because$ & $1 \%$ & 2 & $3 \%$ & $5 \%$ & 7 & 74 & 814 & $2 \%$ \\
\hline 10 & $1 \%$ & $" 1$ & $1 \%$ & $2 \%$ & 314 & $6 \%$ & $7 \%$ & 814 & S'4 & 94 \\
\hline 11 & $1 \%$ & " & 218 & $2 \%$ & $3 \%$ & $2 \%$ & 814 & 94 & 104 & $10 \%$ \\
\hline 12 & $y$ & 1 & $1 \%$ & $2 \%$ & 14 & $7 \%$ & $9 \%$ & $10 \%$ & 11 & $11 \%$ \\
\hline 13 & $\because$ & 1 & $1 \%$ & $2 \%$ & $41 x$ & 814 & 104 & $11 \%$ & 12 & $12 \%$ \\
\hline 14 & 4 & $1 \%$ & 2 & $31 \%$ & $4 \%$ & $9 \%$ & $10^{\prime} 3$ & 12 & $12^{*} ;$ & $13 \%$ \\
\hline 15 & : & $1 \%$ & $2 \%$ & $3 \%$ & $s \%$ & $9 \%$ & 114 & $12 \%$ & 134 & $14 \%$ \\
\hline 15 & 4 & $1 \%$ & $2 \%$ & $31 \%$ & 5'4 & $10 \%$ & $12 \%$ & 134 & $14 \%$ & $15 \%$ \\
\hline 17 & 15 & 14 & $2 \%$ & $3 \%$ & $5 \%$ & $11 \%$ & $13 \%$ & $14 \%$ & $15^{2} \%$ & $16^{\prime \prime}$ \\
\hline 18 & $\because$ & $1 \%$ & $2 \%$ & $\therefore \because$ & $6 \%$ & 114 & $13 \%$ & $15 \%$ & 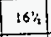 & $17 \%$ \\
\hline 19 & $\because$ & $1 \%$ & 24 & $1 \%$ & 613 & $12 \%$ & $14 \%$ & $16 \%$ & 1713 & $18 \%$ \\
\hline 20 & 4 & 14 & $2 ":$ & $41 / 1$ & 61. & 134 & $15 \%$ & 174 & 184i & 1913 \\
\hline 22 & $"$ & $2 \%$ & $3 \%$ & 5 & $7: 4$ & 1414 & 17 & $18 \%$ & $20 \%$ & $21 \%$ \\
\hline 24 & $"$ & 2 & $31 / 4$ & $51 / 3$ & $3 \%$ & $15 \%$ & $18 \%$ & $20 \%$ & 22 & $231 \%$ \\
\hline 25 & 16 & $2 \%$ & $3 \because 4$ & $5 \%$ & $81 \%$ & $17 \%$ & 204 & $22 \%$ & $23 \%$ & $25 \%$ \\
\hline 28 & $\%$ & 216 & 46 & $6 \%$ & $91 / 4$ & $18^{2}$ & 214 & $23 \%$ & $25 \%$ & $27 \%$ \\
\hline 30 & $\%$ & 214 & 4 & $6 \%$ & $10 \%$ & 194 & $23 \%$ & $25 \%$ & 274 & $29 \%$ \\
\hline 32 & $\because$ & 24 & $4 \%$ & $7 \%$ & 11 & 21 & $24 \%$ & $27 \%$ & 291. & $31 \%$ \\
\hline 34 & $1 \%$ & $2^{2}$ & $s$ & $2 \%$ & $11 \%$ & $22 \%$ & $26 \%$ & 29 & $31 \%$ & ה:"נ3 \\
\hline 36 & 1 & 3 & $5 \%$ & $81 \%$ & $12 \%$ & 234 & $27 \%$ & $30 \%$ & 33 & 35 \\
\hline 38 & 1 & 34 & $5 \%$ & $8 \%$ & 13 & 25 & 294 & $32 \frac{1}{1}$ & $34 \%$ & 37 \\
\hline 40 & 1 & $3 \%$ & $5 \%$ & 9 & $13 \%$ & $20 \div:$ & 31 & $34 / 4$ & $3 \%$ & 39 \\
\hline 42 & $1 \%$ & 3". & $6 \%$ & $9 \%$ & $14 \%$ & $27 \%$ & $32 \%$ & $35 \%$ & 384 & $40 \%$ \\
\hline 14 & 14 & 311 & $6{ }^{\prime \prime}$ & 10 & 15 & 29 & 34 & $37 \%$ & $00 \%$ & $42 \%$ \\
\hline 46 & $11 \%$ & $3 \%$ & $6 !:$ & $10 \%$ & $15 \%$ & $30 \%$ & $35 \%$ & $39 \%$ & $+2 \%$ & d4. \\
\hline 48 & $\therefore$ & 4 & 7 & $10 \%$ & $16 \%$ & $31 \%$ & $37 \%$ & 41 & 44 & $40 \%$ \\
\hline
\end{tabular}

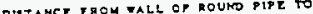

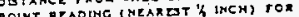

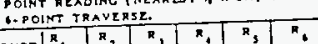

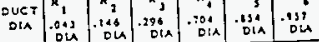
\begin{tabular}{l|l|l|l|l|l|l}
3 & $\%$ & $1 / 4$ & 16 & $2 \%$ & $2 \%$ & $2 \%$ \\
\hline
\end{tabular} \begin{tabular}{l|l|l|l|l|l|l|}
314 & 4 & 4 & 1 & $2 \%$ & 3 & 36 \\
\hline
\end{tabular}

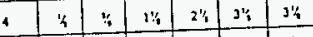
\begin{tabular}{l|l|l|l|l|l|l|}
$41 \%$ & $1 \%$ & $\%$ & 14 & $3 \%$ & $3 \%$ & $4 \%$ \\
\hline $1 \%$ & $1 \%$ & $1 \%$ & $3 \%$ & $4 \%$ & $4 \%$ \\
\hline
\end{tabular}

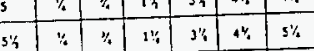
\begin{tabular}{|l|l|l|l|l|l|l|}
\hline 512 & $\%$ & 4 & 14 & 31 & $5 \%$ & \\
\hline 5 & $1 / 4$ & 4 & $1 \%$ & $4 \%$ & 53 & $5 \%$ \\
\hline
\end{tabular} 
PROJECT B-LO3 AMRLOW MEASUREMEVT TAELE FlOW TEST

\begin{tabular}{|c|c|c|}
\hline TEST PORT & LOCATION & AR FLOW REAOINGS \\
\hline 1 & $12 "$ inlet (atove ground) & $\begin{array}{l}398 \text { GFM Mewered Flow } \\
1150 \text { CFMDerisn Flow }\end{array}$ \\
\hline 2 & $\begin{array}{l}\text { "l" exhaust (above ground) } \\
\text { staek }\end{array}$ & $\begin{array}{l}1190 \text { CFM M.F. } \\
1150 \mathrm{CFM} \text { D.F. }\end{array}$ \\
\hline 3 & $\begin{array}{l}\text { 6"dnp io inlet penctiation } \\
N 4764.08 / \omega 47811.04\end{array}$ & $\begin{array}{l}173 \text { CFM M. }= \\
230 C=M \text { DIF }\end{array}$ \\
\hline 4 & 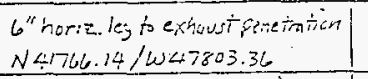 & $\begin{array}{l}193 \text { CFM M.F } \\
192 \mathrm{CFM} \text { O.F. }\end{array}$ \\
\hline 5 & $\begin{array}{l}\text { 3" drep to inlet penctoition. } \\
N 41744.76 / \omega 47793.47\end{array}$ & $\begin{array}{l}42 \text { CNM M.F. } \\
57.5 \text { CFM O.F. }\end{array}$ \\
\hline 6 & $\begin{array}{l}\text { 8"exhaust heoder } \\
N 41722.17 / \omega \div 7798.94\end{array}$ & $\begin{array}{l}179 \text { CFM M.F } \\
192 \text { CFM O.F }\end{array}$ \\
\hline 7 & $\begin{array}{l}\text { Goin/ct header } \\
\text { N4itos.59/w4 } 47800.42 \ldots\end{array}$ & $\begin{array}{l}187 \mathrm{CFM} M \mathrm{MF} \\
230 \mathrm{CFM} \text {. O.F }\end{array}$ \\
\hline 8 & 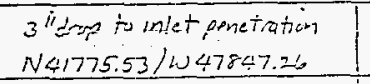 & $\begin{array}{l}43 \text { CFM M.F. } \\
57.5 C F H \text { D.F. }\end{array}$ \\
\hline 9 & $\begin{array}{l}\text { 6" horiz. ley is exhaust panctration } \\
N 4770.56 / \text { Li } 47847.33\end{array}$ & $\begin{array}{l}172 \mathrm{CF} \text { M M.F. } \\
192 \mathrm{CFM} \text { D.F. }\end{array}$ \\
\hline 10 & $\begin{array}{l}\text { 6"drop to inlet penctation } \\
N 41750.41 / 247871.50\end{array}$ & $\begin{array}{l}177 \mathrm{CFM} \text { H.F. } \\
230 \mathrm{CFM} \text { O.F. }\end{array}$ \\
\hline 11 & $\begin{array}{l}\text { C" horiz le, to exhaust penctiotion } \\
N 417444.83 / \omega 47873.06\end{array}$ & $\begin{array}{l}140 \text { CFM M. } \\
192 \text { CFM D.F. }\end{array}$ \\
\hline 12 & $\begin{array}{l}\text { 4"drap to iniet penctration } \\
1141722.24 / \omega 47878.03\end{array}$ & $\begin{array}{l}39 \text { CFM Ml: } \\
57.5 \text { CFM D.F. }\end{array}$ \\
\hline 13 & $\begin{array}{l}\text { C"heriz leg to exhourt penetrati } \\
1 \times 41706.10 / 047863.40\end{array}$ & $\begin{array}{l}172 \text { GiM M.F. } \\
192 \text { CFiM D.F. }\end{array}$ \\
\hline 14 & $\begin{array}{l}\text { G"drop to inletpenetration } \\
N 41697.52 / \omega 47860.91\end{array}$ & $\begin{array}{ll}210 \text { CFin } & M= \\
230 C F M & 0 . \approx\end{array}$ \\
\hline 15 & $\begin{array}{l}\text { G"inlet heuder } \\
N 41691.4 \delta / \omega 47 \delta 24.74\end{array}$ & $\begin{array}{l}45 \mathrm{CFM} \text { M.F. } \\
57.5 \mathrm{CFM} \text { O.F. }\end{array}$ \\
\hline 16 & $\begin{array}{l}\text { 8"exhoust heuder } \\
N 41646.44 / 447824.67\end{array}$ & $\begin{array}{l}163 \mathrm{CFM}, 4 \mathrm{~F} \\
192 \mathrm{CF} \text {. }\end{array}$ \\
\hline
\end{tabular}

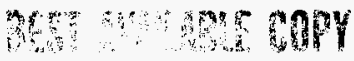


HNF-SD-W320-ER-002, Rev. 0

PROSECT BLT3 AIRFLOW MEAUUREMENT TAELE FLOU TEST: 2

\begin{tabular}{|c|c|c|}
\hline TEST PORT & $=-$ LOCATION & AIR FLOW REGOINGS $\cdots$ \\
\hline 1 & 12 "inlet (abure ground) & $\begin{array}{l}439 \text { 603 } \\
1150 . \text { CFMDesign Flw }\end{array}$ \\
\hline 2 & U" exhaust (above ground). & $\begin{array}{l}57^{67} \mathrm{CFM} \cdot M . F . \\
1150 \mathrm{CFM} \text { D.F. }\end{array}$ \\
\hline 3 & $\begin{array}{l}\text { G"drop io imlet penetation } \\
N 4769.08 / 447811.09\end{array}$ & $\begin{array}{l}\text { BarkEOCFM M.F } \\
\text { Br. CFH D.F. }\end{array}$ \\
\hline $4 . \ldots$. & $\begin{array}{l}\text { 6"hore ley to exhoust fenetration } \\
N 41766.14 / \text { w3 } 47803.36\end{array}$ & $\begin{array}{l}B 0 C F .4 M . F \\
192 C . M M O F . F\end{array}$ \\
\hline 5 & $\begin{array}{l}3^{4} \text { drep to inlet penetiotion } \\
N 4174576 / \omega 47793.97\end{array}$ & $\begin{array}{l}N / A C F M \text { M.E. } \\
2 \delta \& \text { CFM O.F. }\end{array}$ \\
\hline 6 & $\begin{array}{l}\text { "exhaust header } \quad \ldots \ldots . . . . . \\
N 41722.17 / \omega 47798.94\end{array}$ & $\begin{array}{r}90 \text { CFH M.F } \\
192 \text { CFH O.F }\end{array}$ \\
\hline 7 & $\begin{array}{l}\text { Guinlet header } \\
\text { N4i708.55/w47800.42 }\end{array}$ & $\begin{array}{l}\text { BANEO CFM M.F ....... } \\
\text { B. CFM O.F }\end{array}$ \\
\hline 8 & $\begin{array}{l}\text { 3"dop in mlet penetiation } \\
N 41775.53 / 6478 \div 7.26\end{array}$ & $\begin{array}{l}N / A \quad C F M \quad M . F . \\
28 J C F H \text { D.F. }\end{array}$ \\
\hline 9 & $\begin{array}{l}\text { 6" horteleg to exhuest pmetratin } \\
\sqrt{4} 41770.56 / \omega 47847.33\end{array}$ & $\begin{array}{r}82 \mathrm{CFM} M . \mathrm{F} . \\
\therefore 192 \mathrm{CFM} \text { O.F. }\end{array}$ \\
\hline 10 & $\begin{array}{l}\text { G"drop to inlet penctration . } \\
N 417=0.4 / W 47871.50\end{array}$ & $\begin{array}{r}\text { BLANEOCFM M.F. } \\
C=M \text { D.F. }\end{array}$ \\
\hline 11 & 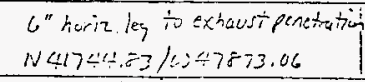 & $\begin{array}{r}86 \text { CFM M.F. } \\
152 \text { CFM D.F. }\end{array}$ \\
\hline 12 & $\begin{array}{l}4 \text { "drap to inlet penetration } \\
N 41722.24 / \omega 47575.03\end{array}$ & $\begin{array}{l}N / A \text { CFM M.F. } \\
288 C F M \text { D.F. }\end{array}$ \\
\hline 13 & $\begin{array}{l}\text { 6"horiz ley to exhowt penetrat } \\
1 \times 41706.10 / \text { w } 47063.40\end{array}$ & $\begin{array}{l}86 \text { CFM M.F. } \\
192 \text { CFM D.F. }\end{array}$ \\
\hline 14 & $\begin{array}{l}\text { 6"dropt inletpentiatien } \\
N 41697.92 / 454700.91\end{array}$ & 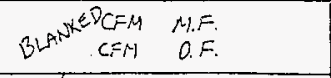 \\
\hline 15 & $\begin{array}{l}6 " \text { inlet heuder } \\
N 41691.4 \hat{\sigma} / \omega 47824.74\end{array}$ & $\begin{array}{l}\text { N/A CFM M.F. } \\
288 \text { CFM O.F. }\end{array}$ \\
\hline 16 & $\begin{array}{l}\sigma^{\prime \prime} \text { exhoust heuder } \\
N 41696.44 / 4,47824.67\end{array}$ & $\begin{array}{l}88 C F M \\
192 C F M\end{array}$ \\
\hline
\end{tabular}

$\therefore-2$ 


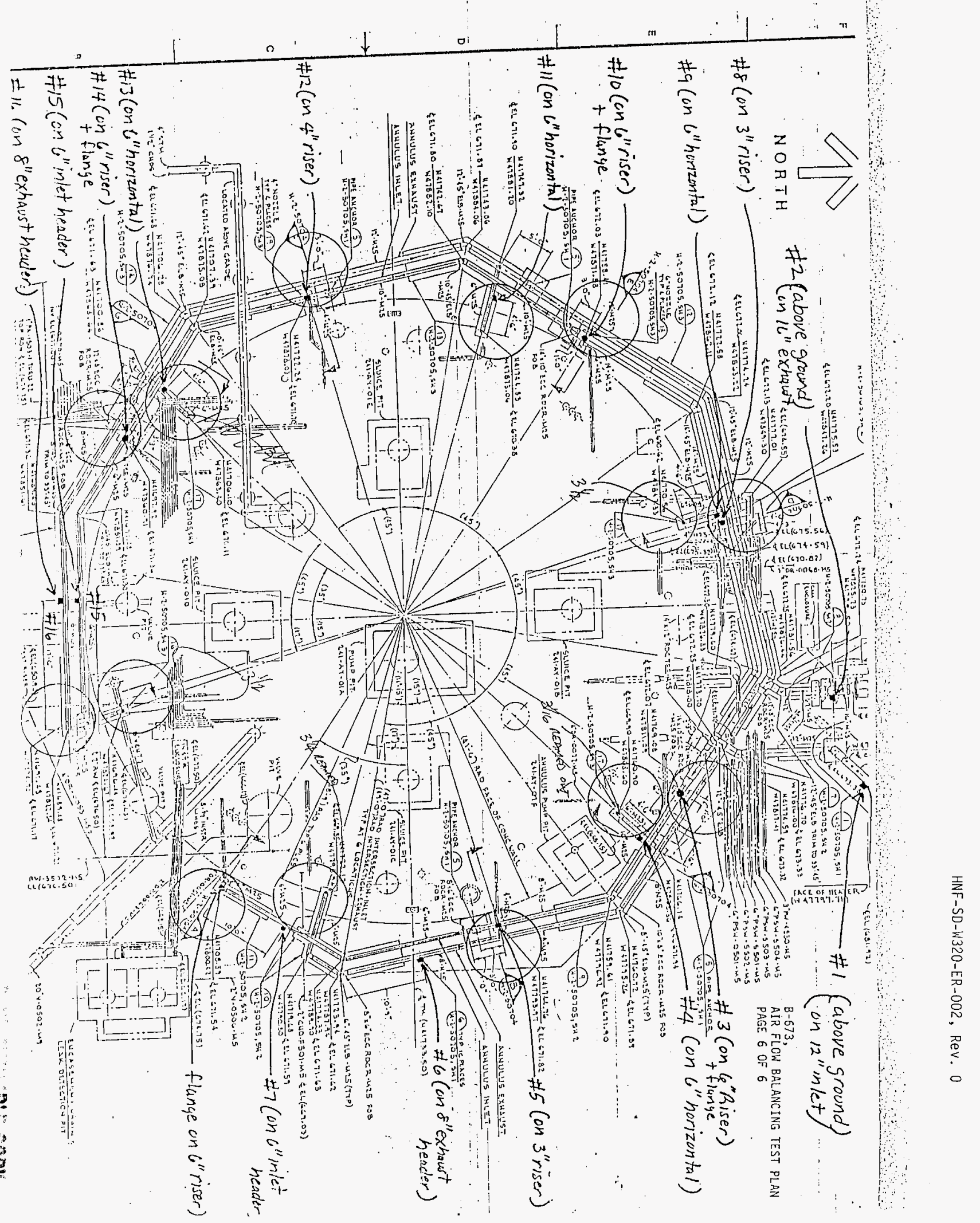


THIS PAGE INTENTIONALLY LEFT BLANK 
HNF-SD-W320-ER-002, Rev. 0

APPENDIX C MC Daily Log from Mark M. Jennings, October 17, 1996. 
HNF-SD-W320-ER-002, Rev. 0

(This page intentionally left blank.) 


\section{DAIIY LOG}

DATE: 17 OCT 96

1.0 STARTED 0730, FINISHED 1600.

2.0 FINALIY, RAN THE 102-AY ANNULUS EXHAUST SYSTEM. GOOD NEWS IT FLOWED APPROXIMATELY 1600 CFM AT 1.5" AND APPROXIMATELY 2373 CFM AT 4" IN THE ANNULUS. THE FILTERS WERE AEROSOL TESTED AND THE FAN VIBRATION TESTED SATISFACTORILY. 3 PHYSICAL DEFICIENCIES NEED TO BE COMPLETED PRIOR TO CLOSING OUT THE WORK PACKAGES;

A. THE CAM PRESSURE SWITCH NEEDS TO BE REPAIRED/REPLACED AS REQUIRED - ASSOCIATED WITH THE $K$ AND RK RELAYS THAT CLEAR THE CAM STACK MONITOR TROUBLE ALARM.

B. THE HEATER CONTROL MODULE THAT CONTROLS THE HEATER NEEDS TO BE SET UP/TROUBLESHOT AND FIXED.

C. THE GAGE LINES TO THE HEPA'S FILTER DP GAGES NEED TO BE REVERSED.

J-7'S REQUIRED;

A. CHANGE THE FLOW ACCEPTANCE CRITERIA IN THE FAN WORK PACKAGE.

OP'S PROCEDURE CHANGES;

A. CHANGE THE FLOW CRITERIA AND ALLOW THE USE OF DAMPER MK-6501 TO SET THE INITIAL TANK PRESSURE. USE THE INLET DAMPER TO CORRECT FOR HEPA LOADING.

THE BAD NEWS FOR THE 320 PROJECT, WITHOUT A GREATER NEGATIVE PRESSURE IN THE PRIMARY THE ANNULUS CAN NOT DELIVER THE 2000 CFM MINIMUM THEY NEED TO ACCOMPLISH THE COOLING FLOW THEY NEED.

3.0 GAVE A QUICK CALI TO BRENT FRYER AND GAVE HIM THE GOOD NEWS ABOUT THE FAN AND SYSTEM. IT WILL FLOW WHAT THEY NEED AT A LOWER PRESSURE. ALSO SENT HIM A CLEAN COPY OE THE FAN CURVE. WILI STAY IN CONTACT WITH THIS GUY.

NEED TO'S

1.0 CONTINUE WORK ON AY WORK PACKAGES. LAST TWO FROM STENKAMP DELIVERED, ALL 8 MAJOR JOBS ARE NOW IN THE, OF OPERATIONS. ADD 2 MORE TO THE HANDS OF TROUBLE, THE STACK SAMPLER ISSUES. 1 DOWN AND 1 TO 6. 
HNF-SD-W320-ER-002, Rev. 0

2.0 VERIFY SHAFT MATERIAL OF SY PRIMARY EXHAUSTERS. IF THEY ARE CARBON STEEL, SEND MEMO TO WICKS, FOX AND WEST DUDE ABOUT THE "DANGERS" OF MIXED MATERIAL, I.E. AMCA GUIDE FOR MSHA.

3.0 GET STARTED ON ECN AND SPEC'S REQUIRED TO INSTALI A NEW INLET FILTER STATION AT AZ ANNULUS.

4.0 GENERATE CC TO WICKS, LILLYFIELD, ROSS, HARTY, HANSON, ECT... THAT EXPLANES LACK OF FLOW BASED ON ANNULUS PRESSURE LIMITATION: CAN GIVE MORE FLOW IF VALVE BETWEEN X CONNECT OPEN AND KI STACK BYPASS CLOSED.

5.0 NEED TO GENERATE ECN TO CLOSE OUT OLD TERRY WORNIC NCR ASSOCIATED WITH AY ANNULUS STACK CABINET. WE INADVERTANLY CORRECTED THIS PROBLEM WHEN WE INSTALIED GROUND RODS ON CAM AND NEW HVAC CONTROL PANELS. GET WITH MANJIT AND JOHN WELLS TO COMPLETE.

6.0 NEED TO CHECK WITH BILL ROSS ABOUT ABU. IF HE REALY WANTS ONE, DELIVERABLE AFTER THE "POST MAINTENANCE TEST".

MARK M. JENNINGS

MAINTENANCE CONCEPTS

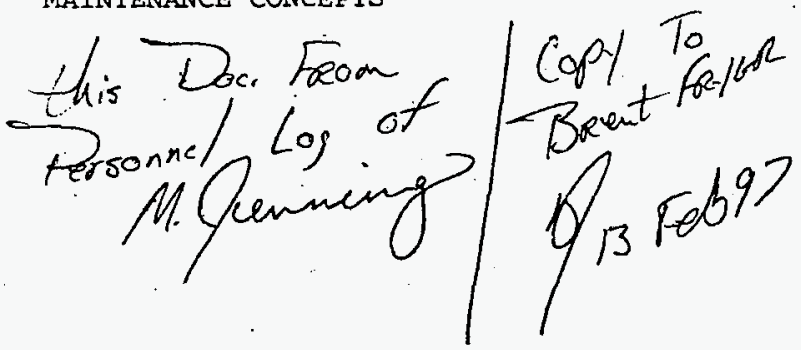


HNF-SD-W320-ER-002, Rev. 0

APPENDIX D Evaluation of AY-102 Slurry Distribution Flow Field 
HNF-SD-W320-ER-002, Rev. 0

(This page intentionally left blank.) 
HNF-SD-W320-ER-002, Rev. 0

\section{CALCULATION OF SURERNATANT FLOW PATTERN DUE TO SUMP PUMP DISCHARGE INTO TANK AY-102.}

\section{INTRODUCTION.}

This note book documents the calculation for the flow pattern in Tank AY-102's supernatant during sluiceing pump operation for Tank C-106 sluiceing. The purpose of the calculation is to provide the flow pattern in the supernatant so that the resultant velocities at the sludge/ supernatant interface can be used to determine if there is a potential for the sluiceing operation to generate a GRE in the tank. It is rot the purpose of this calculation to make that determination but only to provide the supernatant velocities.

\section{GEOMETRY.}

The tank radius is 37.5 feet. The total height of waste in the tank (sludge and supernatant) is 30 feet. The fluffed height of sludge in the tank is 5 feet. The pump discharge distributor in tank $\mathrm{AY}-102$ is located 12.5 feet from the bottom of the tank and consists of two horizontal, 2 inch diameter pipes that are perpendicular to each other, lie in a plane parallel to the waste surface, discharge flow from both ends and are 7.5 inches apart. This geometry is shown in Figure 2.1. The total discharge flow of the pump is $380 \mathrm{gpm}$. 
HNF-SD-W320-ER-002, Rev. 0

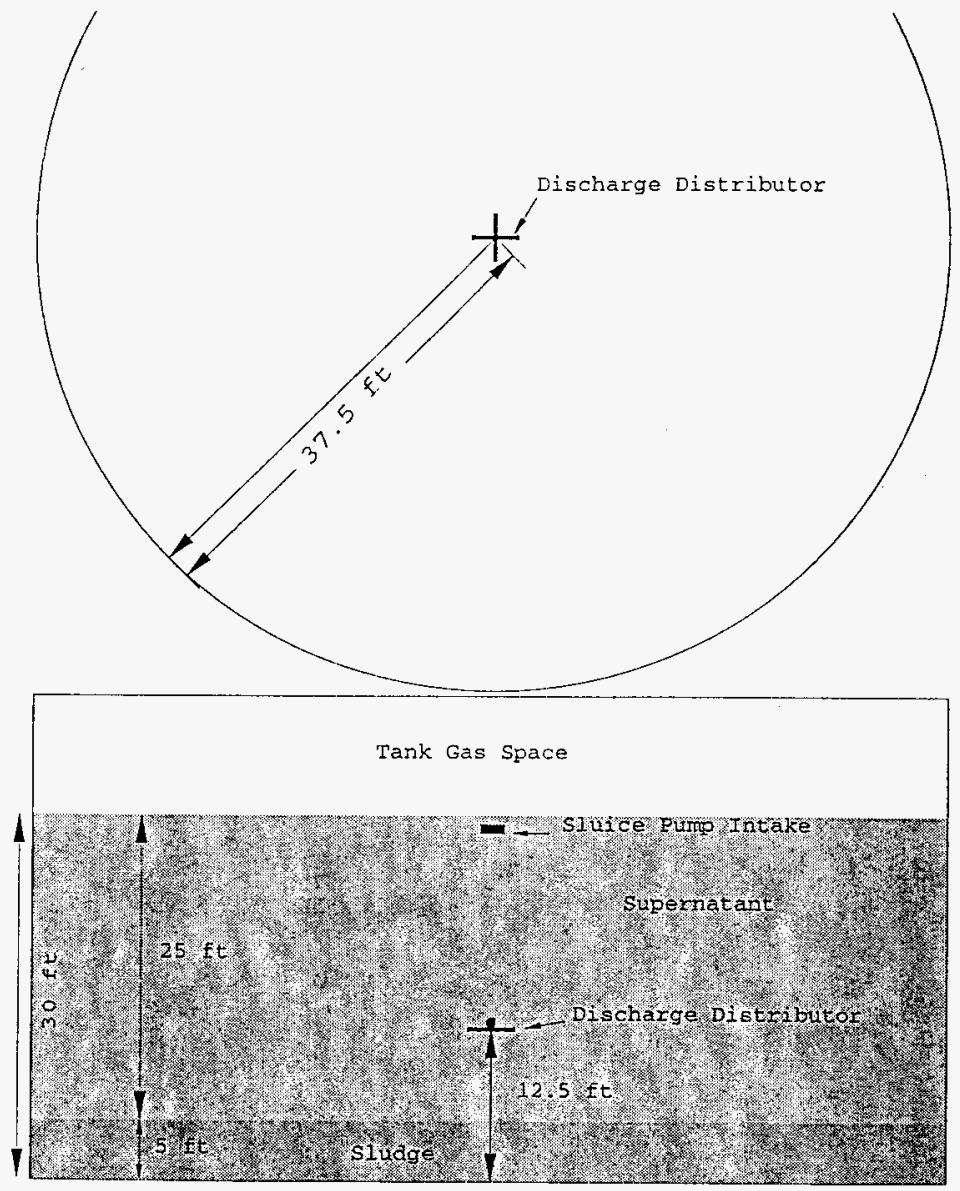

Figure 2.1 Tank, Pump Discharge, Waste and Pump Intake Geometry. 
Important tank dimensions used in the analysis are given below.

$$
\begin{aligned}
& \text { Dtank }:=75 \mathrm{ft} \\
& \text { Hsludge }:=5 \mathrm{ft} \\
& \text { Hwaste }:=30 \mathrm{ft} \\
& \text { Hsupernate }:=\text { Hwaste }- \text { Hsludge }=25 \mathrm{ft}] \\
& \text { Dnozzle }:=2 \text { in }=[0.1667 \mathrm{ft}] \\
& \text { Anozzle }:=\pi \cdot \frac{\text { Dnozzle }}{4} \cdot\left[0.02182 \mathrm{ft}^{2}\right] \\
& \text { Hdischarge }:=12.5 \mathrm{ft} \\
& \text { Vflow }=380 \mathrm{gpm}
\end{aligned}
$$

We will assume an intake diameter of:

$$
\begin{aligned}
& \text { Dintake }:=6 \text { in }=0.5 \mathrm{ft}] \\
& \text { Aintake }:=\pi \cdot \frac{\text { Dintake }}{4}=\left[0.1963 \mathrm{ft}^{2}\right.
\end{aligned}
$$

\section{GOTH MODEL OF SUPERNATANT.}

The tank region of interest for the purposes of this calculation is the supernatant. The following assumptions will be made in developing the GOTH model for the supernatant flow patterns induced by sluicer pump and sump pump operation. 
HNF-SD-W320-ER-002, Rev. 0

1. The sluicer pump intake flow is equal to the sump discharge flow.

2. The free boundary will not effect the solution since the inflow is equal to the outflow except that the free surface is a slip boundary for shear calculations.

3. The sludge boundary will not effect the solution other than to act as a no slip boundary for the flow solution.

4. Both arms of the discharge distributor are at the same elevation and each arm receives equal flow.

5. The sluiceing pump intake is located on the tank centerline near the supernatant surface.

6. The supernatant has the properties of water.

The above assumptions allow us to model the supernatant only and to use 1/8th tank symmetry for the computational mesh. The mesh used in the calculation is shown in the Figure below. 
HNF-SD-W320-ER-002, Rev. 0

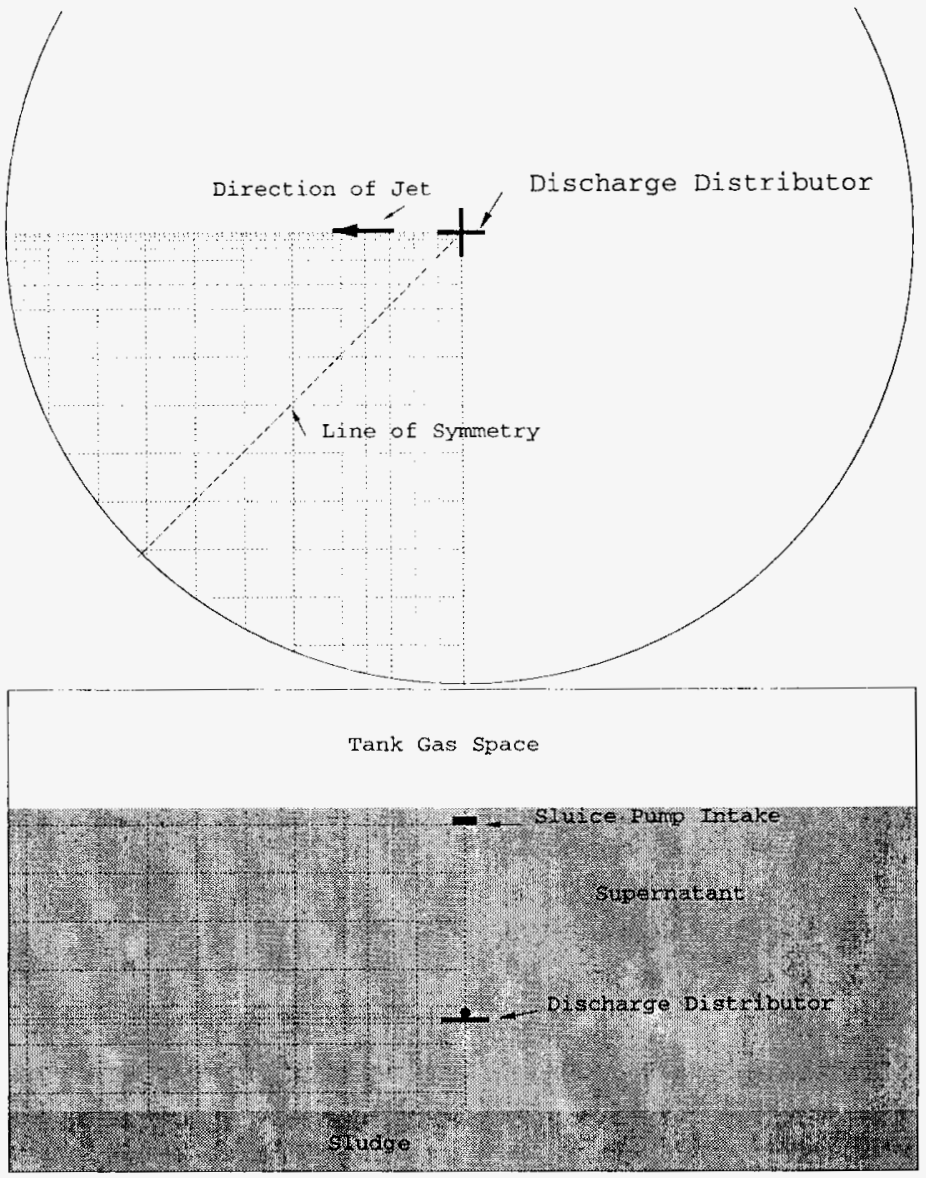

Figure 3.1 GOTH Computational Mesh 


\section{CALCULATION RESULTS.}

The results of the simulation can be summarized as follows. The jet remains horizontal until it reaches the tank wall. The momentum of the jet is aissipated due to mixing with the surrounding fluid in the supernatant pool. The velocity of the jet at the nozzle is $9.7 \mathrm{ft} / \mathrm{s}$. The centerline velocity of the jet at the wall is $1.5 \mathrm{ft} / \mathrm{s}$. The velocity of the jet is further reduced as it impinges against and spreads radially outward on the tank wall. The peak velocity of the fluid coming down the wall in the form of a wall jet is estimated from [Blevins, p240] using the jet average velocity at the wall from the GOTH simulation, the diameter of the horizontal jet at the wall and the distance from the horizontal jet centerline to the waste surface. This is done because the node size used in the simulation is too large to calculate the velocity profile in the wall jet.

The radius of the horizontal jet at the tank wall is estimated from the GOTH calculation to be:

$$
r_{0}:=0.4 \mathrm{ft}
$$

The average velocity of this jet at the wall is estimated from the GOTH calculation to be:

$$
\mathrm{U}_{\mathrm{o}}:=1.25 \frac{\mathrm{ft}}{\mathrm{s}}
$$

Using Blevin's formula, the maximum velocity in the wall jet where the wall jet impinges on the waste surface at the wall is:

$$
\mathrm{U}_{\mathrm{m}}:=2.1 \cdot\left(\frac{\mathrm{r}_{0}}{\text { Hdischarge }- \text { Hsludge }}\right) \cdot \mathrm{U}_{\mathrm{O}}=\left[\begin{array}{c}
\mathrm{ft} \\
\mathrm{s}
\end{array}\right]
$$

This is the maximum velocity impinging on the waste surface. 
The GOTH calculated velocity at the waste/wall interface is about $0.1 \mathrm{ft} / \mathrm{s}$ so the large mesh at the wall is acceptable since the wall jet has been dissipated to the width of the mesh cell by the time it impinges on the waste surface. A new wall jet is formed where the first wall jet impinges on the waste surface. This jet spreads out horizontally over the surface of the waste moving back towards the tank centerline and eventually rising towards the discharge nozzle in a recirculating flow. The velocities induced along the surface of the waste vary from on the order of $0.1 \mathrm{ft} / \mathrm{s}$ at the wall to a few hundredths of a foot per second over most of the waste surface.

A few select vector plots of the flow field are shown in the following figures.

A vector plot of the velocities along the discharge jet centerline in a vertical plane going from the waste surface to the supernatant surface are shown in Figure 4.1. The horizontal jet and its dissipation is clearly evident in this figure. The velocities in the flow field outside of the jet are more easily seen in a vector plot of the same plane which plots the velocities to the 0.25 power which shortens the length of high velocity vectors and increases the length of low velocity vectors, Figure 4.2. The peak velocity at the waste surface in this figure is at the wall, on the left hand side of the figure and is on the order of $0.1 \mathrm{ft} / \mathrm{sec}$. The radial wall jet is shown in Figure 4.3 which is a vector plot of the velocities in a plane at the wall which is normal to the discharge jet centerline. Velocities in a plane parallel to this one but closer to the discharge nozzle are show in Figure 4.4. Maximum velocities at the waste surface at this location are on the order of $0.02 \mathrm{ft}$ per second. The velocities in a plane parallel to the discharge jet but a few inches to the side are shown in Figure 4.5. The peak velocities at the waste surface in this plane are on the order of 0.1 $\mathrm{ft} / \mathrm{s}$. 
HNF-SD-W320-ER-002, Rev. 0

ay $102 \mathrm{sin}$

Thu Feb 27 16:35:46 1997

GOTH Version 3.4- April 1991

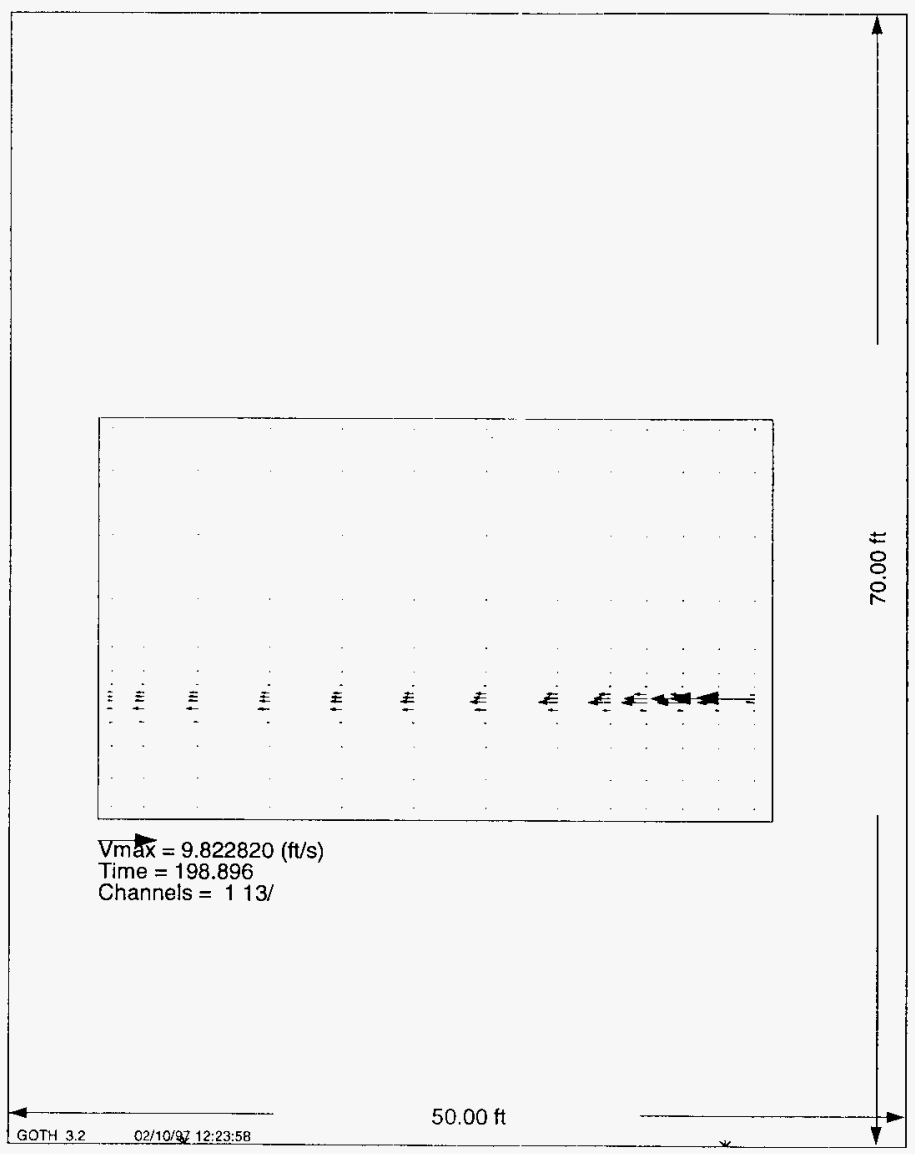

Figure 4.I Supernatant Velocities Along Discharge Jet Centerline in the Vertical Plane. 
HNF-SD-W320-ER-002, Rev. 0

ay $102 \mathrm{sn}$

Thu Feb 27 16:37:42 1997

GOTH Version 3.4 - April 1991

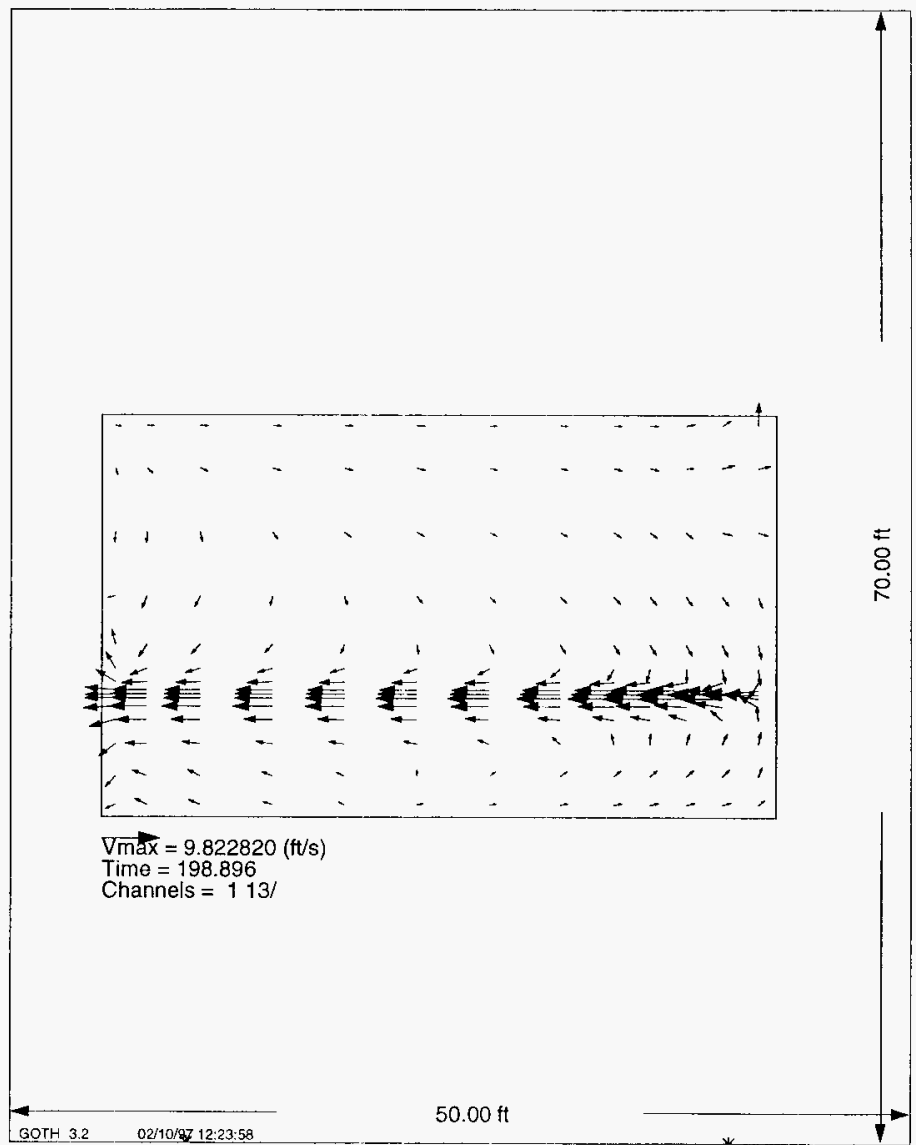

Figure 4.2 Supernatant Velocities to the 0.25 power Along Discharge Jet Centerline in the vertical Plane. 


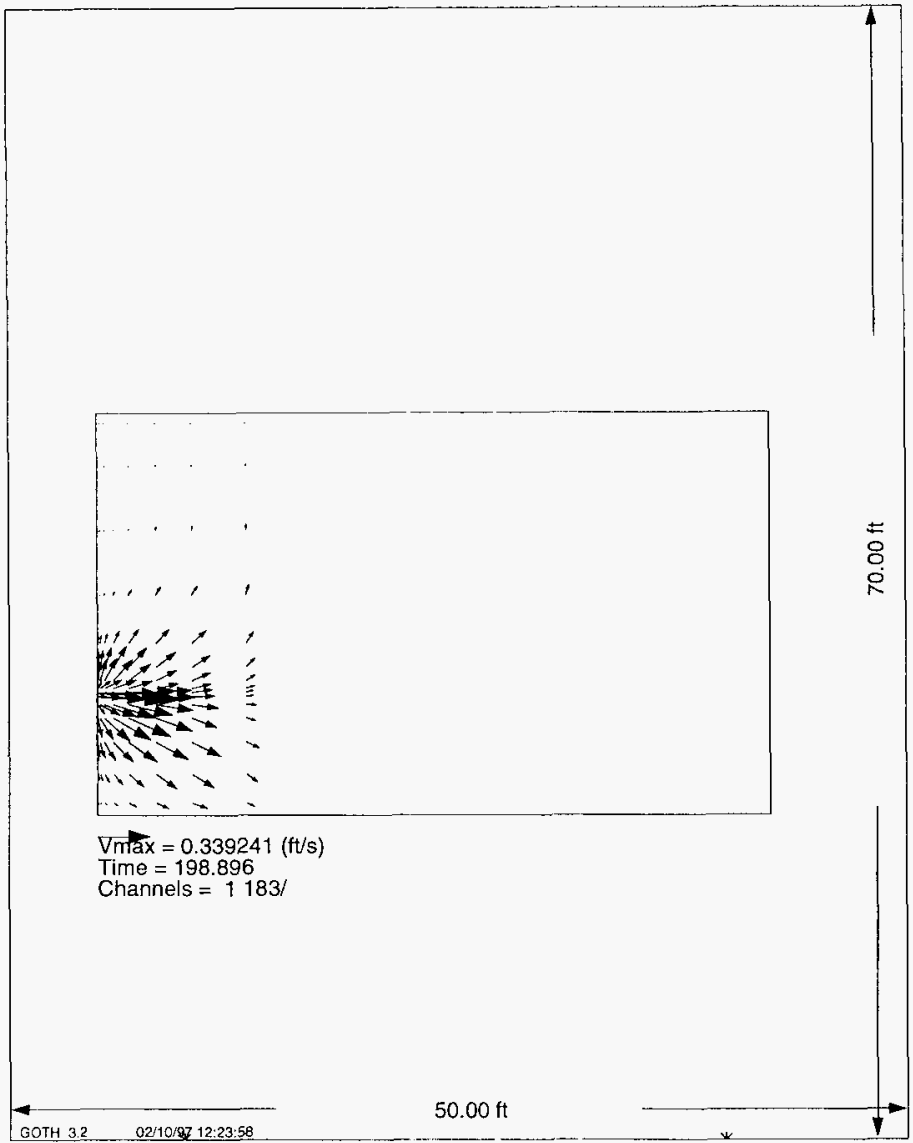

Figure 4.3 Supernatant Velocities At the Tank Wall in the Vertical Plane Normal to the Discharge Jet. 
HNF-SD-W320-ER-002, Rev. 0

ay $102 \mathrm{sn}$

Thu Feb 27 16:41:23 1997

GOTH Version 3.4 - April 1991

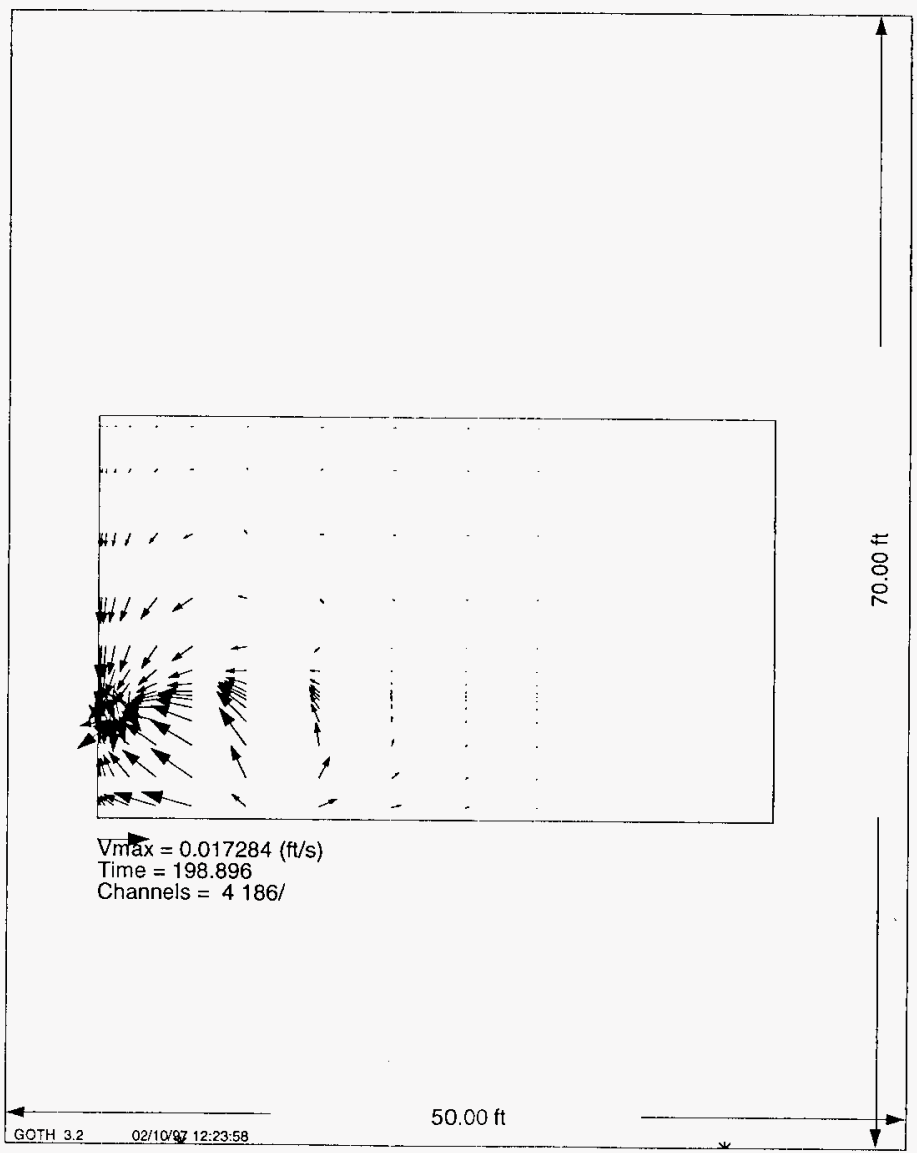

Figure 4.4 Supernatant Velocities Nearer the Discharge Nozzle in a Vertical Plane Normal to the Discharge Nozzle. 
ay $102 \mathrm{sn}$

Thu Feb 27 16:42:47 1997

GOTH Version 3.4 - April $199 t$

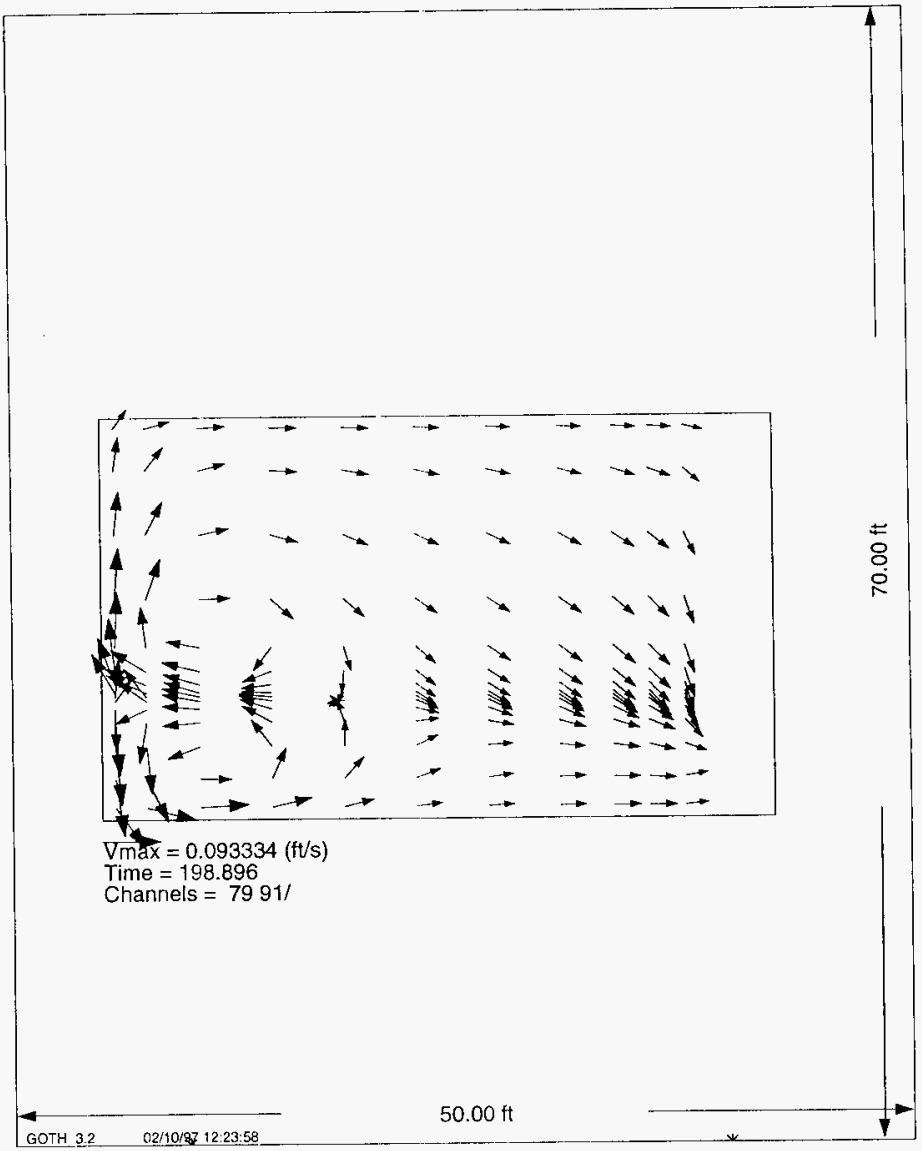

Figure 4.5 Supernatant Velocities Along Discharge Jet Centerline in the Vertical plane a Few inches Radially out From the Discharge Jet Center. 
HNF-SD-W320-ER-002, Rev. 0

\section{CONCLUSIONS.}

The supernatant velocities at the waste surface induced by sump pump discharge into tank AY-102 are on the order of $0.15 \mathrm{ft} / \mathrm{sec}$ where the wall jet impinges on the waste surface and are a few hundredths of a foot per second over the bulk of the waste surface.

\section{REFERENCES}

Blevins, Robert D., Applied Fluid Dynamics Handbook, Van Nostrand Reinhold Company, 1984, New York, New York, P 240. 
HNF-SD-W320-ER-002, Rev. 0

(This page intentionally left blank.) 
HNF-SD-W320-ER-002, Rev. 0

\section{APPENDIX E Tank 241-AY-102 Annulus and Floor Cooling Channel Flows}

1. cc:Mail Gary Tardiff to K. Sathyanarayana et al., dated August 30, 1995.

2. cc:Mail Gary Tardiff to John Conner dated September 21, 1995. 
HNF-SD-W320-ER-002, Rev. 0

(This page intentionally left blank.) 
HNF-SD-W320-ER-002, Rev. 0

[27] From: Gary R Tardiff at -WHC338 8/30/95 10:26AM (1503 bytes: 1 In)

To: K Sathyanarayana at - WHC63, John C Conner at -WHC150, John P III Harris at - HHC216, Donald M Ogden at - WHC63

cc: Hatthew S Tiffany, Gary R Tardiff, Gregory N Hanson at -WHCI29,

James H Jr Wicks at -WHC396, Ryan A Dodd, Scott R Pierce, Mark M Jennings at -KEH10

Subject: AY-102 Annulus Exhauster

Message Contents

Text item 1: Text_1

John,

The flow rate for 102-AY annulus exhauster was set at $1000 \mathrm{cfm}$ for the existing conditions 3 to 4 years ago. The existing system is rated for $3525 \mathrm{cfm}$ at $350 \mathrm{~F}$. Since we do not know what the actual temperature will be when we restart the system, the plan was to shoot for $-2000 \mathrm{cfm}$ at say $80-120 \mathrm{~F}$. The HEPA filters can handle up to 4000 SCFM $(60 \mathrm{~F})$. Since we have a $15 \mathrm{hp}$ motor, it may be possible to increase the flow to $-3000 \mathrm{cfm}$ at $100 \mathrm{~F}$.

I hope this answers you questions for your calculations for W-320. Call me at 373-5539 if you have further questions.

PS. I talked with Mark Jennings (exhauster specialist) and we will try to emergency order the equipment we need. We will need Jim Wicks approval but with a word to Jim from you may help speed things up! 
[35] From: John C Conner at -WHC150 9/21/95 1:11PM (2059 bytes: 1 1n)

Priority: Urgent

To: Donald M Ogden at -WHC63

Receipt Requested

CC: K Sathyanarayana at -WHC63, John P III Harris at -WHC216

Subject: Re[2]: Receipt of $9 / 21 / 95$ 9:39 AM message

From: Gary Rardiff at -

From: Gary $R$ Tardiff at -WHC338 $9 / 21 / 9512: 55 \mathrm{PM}$ (1433 bytes: $1 \mathrm{ln}$ )

Priority: Urgent

To: John C Conner at -WHC150

Receipt Requested

cc: Mark M Jennings at -KEH10, Scott $R$ Pierce, Matthew S Tiffany

Subject: $\operatorname{Re}[2]:$ Receipt of 9/21/95 9:39 AM message

(1) Message Contents

Interesting cc:mail recentiy received.

John C.

Forward Header

Subject: Re[2]: Receipt of $9 / 21 / 959: 39$ AM message

Author: Gary R Tardiff at - WHC 338

Date: $\quad 9 / 21 / 9512: 55 \mathrm{PM}$

John,

I'm not sure. Mark Jennings indicated that $2000 \mathrm{cfm}$ is possible.

$3000 \mathrm{cfm}$ is questionable. I think Mark or Scott can better answer your question.

Mark or Scott piease respond to John's question! Thanks Gary Tardiff

Reply Separator

Subject: Re: Receipt of 9/21/95 9:39 AM message

Author: John C Conner at wHC150

Date: 9/21/95 11:31 AM

Gary:

Is verification of the $3000 \mathrm{cfm}$ for the rate of the existing annulus exhauster possible? As you can see, the conTROLS are dependent upon this.

John C.

Reply Separator

Subject: Receipt of 9/21/95 9:39 AM message

Author: Gary R Tardiff at -WHC 338

Date: $9 / 21 / 9511: 18$ AM 
HNF-SD-W320-ER-002, Rev. 0

\footnotetext{
John, below is my summary of the telephone conversation with scott Pierce regarding the $\mathrm{AY}-102$ annulus floor ventilation.

COMMENT: Is verification of the $3000 \mathrm{cfm}$ for the rate of the existing annulus exhauster possible?

* Currently the $A Y-102$ fan is not operating and is in the process of being replaced.

* The procurement spec has not gone out but the work package is designed to be a maintenance type changeout without any modification thus streamlining the design change process and cost requirements.

* The procurement spec as it currently reads is for $2000 \mathrm{cfm}$ at 8 inches static head

* It looks as though $3000 \mathrm{cfm}$ is possible at approximately 6.5 inches static head but it would be close. The system has 3 HEPA filters at check $1000 \mathrm{cfm}$ so reaching the $3000 \mathrm{cfm}$ is manageable however scott will

with the maintenance folks to ensure other factors don't exist. There the are some contingencies (larger motor etc.) that could be done to get

$3000 \mathrm{cfm}$ if needed.

* $3000 \mathrm{cfm}$ would not require a change to the existing procurement spec.

* Schedule: currently behind in submitting the procurement spec which needs a 6 month lead. Expect to be up and running in about 6 to 9 months.

Thank you scott! Any corrections?

Lee
} 
HNF-SD-W320-ER-002, Rev. 0

(This page intentionally left blank.) 
HNF-SD-W320-ER-002, Rev. 0

\section{APPENDIX F Fluffing Factor}

cc:Mail Dan Reynolds to K. Sathyanaryana, February 6, 1997, Fluff Factor and Cs137 heat ccontent of $\mathrm{C}-106$ sludge. 


\section{HNF-SD-W320-ER-002, Rev. 0}

(This page intentionally left blank.) 
HNF-SD-W320-ER-002, Rev. 0

[378] From: Daniel A Reynolds at HANFORD04C 2/6/97 2:01PM (1463 bytes: 1 in) To: K Sathyanarayana at $-W H C 304$

Subject: Re: Fluff Factor and Cs137 heat content of C-105 sludge

i JUST SENT YOU THAT SPREDSHEET. Thanks for the Doc. by Brooks.

I wish I could give you a good value on teh Cs-137. I am going to try and get you the radiation on each core but I haven't found it.

Yesterday, we looked at the Babad report which showed about equal curies of $\mathrm{Sr}$ and $\mathrm{Cs}$ on several samples. However, that Brooks doc. shows a very large difference between $\mathrm{Sr}$ and $\mathrm{Cs}$. That is interesting as it is from the very same grab samples.

Reply Separator

Subject: Fluff Factor and Cs137 heat content of C-106 sludge

Author: K Sathyanarayana at -WHC304

Date: $\quad 2 / 6 / 979: 10 \mathrm{AM}$

Dan:

Kindly please confirm the results of your calculations

regarding the fluff factor for the transferred $\mathrm{C}-106$ sludge

in Tank AY-102. Also please provide me with the heat

content due to Cs137 presence in C-106 sludge.

Thanks

Sathya 
HNF-SD-W320-ER-002, Rev, 0

Summary

\begin{tabular}{|c|c|c|c|c|c|c|c|c|c|c|}
\hline & Start & Sample A IS & Sample B & Sample B1 & Sample C & Sample D & & & & \\
\hline Solids & 5.785363 & 4.76 & 0.29 & 0.59 & 0.09 & 0.06 & & & & \\
\hline sludge & 15.14 & 12.45 & 0.77 & 1.53 & 0.22 & 0.16 & & & & \\
\hline water & 28.8 & 23.69 & 1.47 & 2.92 & 0.43 & 0.30 & & & & \\
\hline \multirow[t]{2}{*}{ total } & 43.94 & 36.14 & 2.24 & 4.45 & 0.65 & 0.46 & & & & \\
\hline & & & & & & & & & & \\
\hline \multicolumn{11}{|c|}{ gm sludge/gm total } \\
\hline & 0.344561 & $=15.14 /(15$. & $.14+28.8$ & & & & & & & \\
\hline & & & & & & & & & & \\
\hline \multicolumn{11}{|c|}{ gm solids/gm sludge } \\
\hline & 0.382124 & $=0.295 / 0.77$ & & & & & & & & \\
\hline \\
\hline \multirow{2}{*}{\multicolumn{11}{|c|}{ - }} \\
\hline & & & & & & & & & & \\
\hline \\
\hline \\
\hline & & $\begin{array}{l}\text { Sludge, } \\
\text { gm }\end{array}$ & $\begin{array}{l}\text { Sludge } \\
\text { Density, } \\
\mathrm{gm} / \mathrm{mL}\end{array}$ & $\begin{array}{l}\text { Sludge } \\
\text { volume, } \mathrm{ml}\end{array}$ & $\begin{array}{l}\text { Solids } \\
\text { mass, gm }\end{array}$ & $\begin{array}{l}\text { Slurry } \\
\text { Volume. } \\
m L\end{array}$ & $\begin{array}{l}\text { Wt\% } \\
\text { Solids in } \\
\text { Silurry }\end{array}$ & $\begin{array}{l}\text { Initial } \\
\text { Sludge } \\
\text { height, } \\
\text { mm }\end{array}$ & $\begin{array}{l}\text { Final } \\
\text { Sludge } \\
\text { height, } \\
\text { mm }\end{array}$ & $\begin{array}{l}\text { Fluff } \\
\text { Factor }\end{array}$ \\
\hline \multirow[t]{6}{*}{ Lumelta } & Leach $\# 1$ & 12.45 & 1.5 & 8.301617 & 4.76 & 45 & $9 \%$ & 11 & 12 & 1.09 \\
\hline & Leach \#2 & & & & & & & 12 & 11. & 0.92 \\
\hline & Wash \# & & & & & & & 11 & 11 & 1.00 \\
\hline & Wash $\$ 2$ & & & & & & & 11 & 10 & 0.91 \\
\hline & Wash \#3 & & & & & & & 10 & 11 & 1.10 \\
\hline & & & & & & & & & & \\
\hline \multirow{4}{*}{ Crawford } & $6 C-96-8$ & 9.98 & 1.5 & 6.65 & & & & 6.65 & 9 & 1.35 \\
\hline & $6 C-96-14$ & $\begin{array}{r}-3.93 \\
\end{array}$ & 1.5 & 2.62 & & & & 2.62 & 3. & 1.15 \\
\hline & $6 \mathrm{C}-96-8 / \mathrm{A}$ & 8.9 & 1.5 & 5.93 & & & & 5.93 & 10 & 1.69 \\
\hline & $6 \mathrm{C}-96-14 / A$ & 9.11 & 1.5 & 6.07 & & & & 6.07 & 7.5 & $1.2 \overline{3}$ \\
\hline
\end{tabular}

\begin{tabular}{|r|r|r|r|r|r|r|r|r|}
\hline & & & & & & & & \\
\hline \\
\hline
\end{tabular}


HNF-SD-W320-ER-002, Rev. 0

APPENDIX G Fluff Factor including the effect of dissolution of solids. cc:Mail Graham T MacLean to John Bailey dated February 12, 1997, Sluiced C-106 Sludge. 


\section{HNF-SD-W320-ER-002, Rev. 0}

(This page intentionally left blank.)

G- $i \mathbf{i}$ 
[382] From: Graham T Maclean at -WHC347 2/12/97 5:20PM (10048 bytes: 1 In) To: John W Bailey at - HANFORDIOC

CC: Daniel A Reynolds at -HANFORDO4C, Scott D Estey at - HANFORO04C,

Nicholas W (Nick) Kirch at -HANFORD04C, Keith E Carpenter at -WHC302, David E Bowers at -HANFORD04B, Susan K Farnworth at - HANFORDO7E,

K Sathyanarayana at -WHC304

Subject: $\operatorname{Re}[3]$ : S1uiced C-106

Message Contents John,

I got carried away with my responses. See below. I hope you enjoy them.

Graham

Subject: $\operatorname{Re}[2]:$ STujced $[-10 \overline{10}$

From: John $W$ Bailey at -HANFORDIOC

Date: $2 / 12 / 97 \quad 12: 43 \mathrm{PM}$

Graham,

What's the petigy on the mixing model, ie., what range of deviation should we expect the real results to deviate from the model predications, below? I beleive the majority of the uncertainty is with the tank compositon estimate, and I dare not guess at that.

If you can get good waste composition data into ESP, it seems to do a pretty good job of determining what is in which phase (with a few secret manipulations). Most of the metals other than Na, K, and $\mathrm{Cs}$ are very insoluble at $\mathrm{pH} 10-12$, and it is straight forward to predict solubility - none! The tricky part is getting the aluminoslicate and sodium oxalate and carbonate/bicarbonate speciation and solubility correct. I think we are pretty close. Temperature is very jmportant - I did the same simulation with C-106 at 35-C rather than 55-, and the sludge was about $27 \mathrm{wt} . \% \mathrm{NaHCO}_{3}$, rather than $20 \%$.

By the way, where did you get that word petigy? It sounds like deviant behavoir to me.

JW Baitiey

Scott \& Graham,

See my comments / questions in the text below.

JW Bailey

Subject: Re: Sluiced $\mathrm{C}-\overline{106}$

Reply Separator

Author: Scott D Estey at HANFORD04C

Date: $2 / 11 / 97$ 11:02 AM

John,

The amount of solids in solution seenis higher than typical earlier estimates but I don't think it is a surprise. D. Reynolds is planning to address this issue in a Calc-Note. Solids dissolution is important 
HNF-SD-W320-ER-002, Rev. 0

in specifying how the mass flowmeter or Enraf densitometer will be used to calculate the amount of precipitated solids transferred.

$S \cot t$

Subject: STuiced C-106

Reply Separator

Author: John $W$ Bailey at -HANFORDIOC

Date: 2/10/97 5:13 PM

Scott,

Any surprises in the below information from Graham?

$J 48$

Subject: Sluiced $\mathrm{C}-106$

Forward Header

Author: Graham T Maclean at $-\mathrm{HHC} 347$

Date: $2 / 10 / 9712: 58$ PM

Sluicing of C-106 - ESP Simulation Results

As part of the efforts to simulate the preparation of the feeds for the private high level waste vitrification pilot plant (Phase 1), I have simulated the sluicing of Tank $C-106$ into AY-102. I thought $y^{\prime}$ al1 might be interested in the results.

I used Steve Lambert's "Best Basis Inventory Estimate" for the overall composition of Tank C-106 (WHC-SD-WM-TI-740 draft). Scott / Graham, How does this documents inventory estimate compare to our FDC and SAD assumed characterizations? I have not compared them. For AY-102 supernatant 1iquid, I used the analyses of grab

samples taken from the tank on Oct. 8, 1996 (Waste Compatibility Results for AY-102 Crab Samples, RFSH-9656442), kindly supplied by Todd Blaak. I adiabatically mixed 650,000 gal. of AY-102 1 iquid and 20,000 gal. of 50 wt.\% NaOH with the entire contents of $\mathrm{C}-106$ inside my computer, and here are the results:

\section{C-105 Composition - ESP Equilibrium Estimate}

Temperature: $55-\mathrm{C} \quad \mathrm{pH}=9.7$ (at $55-\mathrm{C}$ )

Total Mass of Liquid: $887,000 \mathrm{kG}$

Total Mass of Precipitate: $581,000 \mathrm{kG}$

Total Volume of Liquid: 692,0001

Total Volume of Precipitate: 175,000 L

Density of Liquid: 1.28 Scott, This SpG is much higher than what you'd predicted earlier (1.06 or 1.07). Will this significantly impact our earlier settling projections? As Scott said, 1.28 is the SG of the interstitual liquid in C-106, not the sluiced mixture.

Incidentally, this value agrees well with sodium numbers for centrifugate from the grab samples, but not with the decanted supernatant liquid densitites, which were lower. The reason, I believe, is because during the grabbing, some surface 
liquid from $\mathrm{C}-106$ followed the sampler, and flowed into the bottle, carrying sludge with it.

This is born out by the fact that the grab samples contained about half the concentration of precipitated solids as did the 1986 core sample. From my observations and others description of compacted sludge such as $\mathrm{C}-106$ waste, I doubt that some material will flow into a sample bottle without some dilution and mixing with jiquid.

Density of Precipitate: 3.31

Total Dissolved Solids Conc. in Liquid: 31.8 wt.\%

Precipitated Solids Conc. in Tank: 39.6 wt.\% Graham \& Scott, Does the 2, above, solids concentrations say that nearly $1 / 2$ of the C-106 waste is going to desolve when we sluice it? If that is true our thermal model results are all vastly in error, ie., they assumed no or almost no solids dissolution and solids height is the largest driver for thermal steam bump problems. Not quite. When the sludge is sluiced, it will not settle to the same decree of compaction - the old fluffing phenomena. It has been generally found that compacted waste sludges are about 40 wt.\% precipitated solids (or about 18 particle vol.\%). When small quantities of these siudges are mixed up with water and allowed to settle for a month, the sludge layer is about 15 wit.\% water insoluble solids. In a tank with 10 feet of freshly settled sludge, the expected conc. is about 20 wt.\%. Hence, a fluffing factor of about 2 is used.

From the core sample data, I calculated that $c-106$ sludge was 42 wt:\% precipitate in 1986. Brooks found in his 4 liter column that the grab sample material from C-106 settled to about 20 wt-\% or more insoluble solids after washing, confirming the 2 to 1 fluff. FThis is what Sathya used in his CFD and other simulations - but dissolution was not accounted for.

If you take $\mathrm{C}-106$ at $40 \mathrm{wt} . \%$, dissolve $25 \%$ of the precipitate while sluicing (this is the ESP prediction), then let it settle to 20 wt.\%, you get an over all sludge volume increase of about 1.5 . I believe Sathya is revising his calculations with this new factor. This factor can be reduced more by increasing the caustic addition before sluicing to dissolve the $\mathrm{Al}(\mathrm{OH}) 3$, and perhaps the $\mathrm{Na}$ oxalate. Get those caustic orders in!

Composition of precipitate:

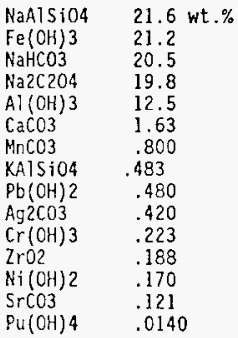

Composition of 1iquid: $\mathrm{Na} 2 \mathrm{CO}, \mathrm{NaNO2,} \mathrm{NaHPO4,} \mathrm{and} \mathrm{NaHCO}_{3}$ in solution.

The manganese is probably present as $\mathrm{MnO4}$, but both species are very insoluble 
in the mixture.

C-106/AY-102 Liquid/Caustic Mixture Composition - ESP Equilibrium Estimate

Temperature: $41-\mathrm{C} \quad \mathrm{pH}=12.1$ (at $41-\mathrm{C}$ )

Total Mass of Liquid: $3,650,000 \mathrm{kG}$

Total Mass of Precipitate: $438,000 \mathrm{kG}$

Total Volume of Liquid: $3,250,000 \mathrm{~L}$

Total Volume of Precipitate: $120,000 \mathrm{~L}$

Density of Liquid: 1.12

Density of Precipitate: 3.63

Total Dissolved Solids Conc. in Liquid: 13.8 wt.\%

Precipitated Solids Conc. in Tank: 10.7 wt.\%

Composition of precipitate:

$\begin{array}{lc}\mathrm{NaAlSiO} 4 & 28.4 \\ \mathrm{Fe}(\mathrm{OH}) 3 & 28.2 \\ \mathrm{Na} 2 \mathrm{C2O4} & 20.9 \\ \mathrm{Al}(\mathrm{OH}) 3 & 16.1 \\ \mathrm{Ca} 3 \mathrm{PO} 4 & 2.22 \\ \mathrm{MnCO} 3 & 1.06 \\ \mathrm{KAlSi04} & 1.21 \\ \mathrm{~Pb}(\mathrm{OH}) 2 & .638 \\ \mathrm{Ag} 2 \mathrm{CO} & .558 \\ \mathrm{Cr}(\mathrm{OH}) 3 & .316 \\ \mathrm{ZrO2} & .249 \\ \mathrm{Ni}(\mathrm{OH}) 2 & .226 \\ \mathrm{SrCO3} & .0161 \\ \mathrm{Pu}(\mathrm{OH}) 4 & .0186\end{array}$

Composition of liquid: $\mathrm{Na} 2 \mathrm{CO} 3, \mathrm{NaNO} 2, \mathrm{Na2C2O4}$, and $\mathrm{Na} 3 \mathrm{PO} 4$ in solution with $\mathrm{OH}-1$ $=.048 \mathrm{~mol} / \mathrm{L}$.

ESP predicts all of the $\mathrm{NaHCO}_{3}$ and some $\mathrm{Al}(\mathrm{OH}) 3$ and $\mathrm{Na2C204}$ will dissolve from the $C-106$ sludge when mixed with the caustic and $A Y-102$ Tiquid. The volume or mass of sludge in the final mixture can be further reduced by adding more caustic.

If you desire more information, or would like an electronic copy of the ESP report, please let me know (specify wt.\% or mol/hr for species conc.)

The above results appear to be consistant with the laboratory results obtained by Lumetta et al. for the washing and leaching of $\mathrm{C}-106 \mathrm{grab}$ samples (PNNL.$11381)$. They found a considerable portion of the precipitated $C-106$ solids dissolve when washed, and that substantial amounts of the $\mathrm{Al}, \mathrm{K}, \mathrm{Na}$, and $\mathrm{Si}$ resisted dissolution by leaching.

Graham Maclean

372-0405 
HNF-SD-W320-ER-002, Rev, 0

\section{APPENDIX H Cs137 Heat Load of Tank 241-C-106}

Meeting Minutes \#3 From W. J. Powell to Distribution, 102-AY Annulus Ventilation System, Nov. 1996. 
HNF-SD-W320-ER-002, Rev. 0

(This page intentionally left blank.)

$H-i j$ 
HNF-SD-W320-ER-002, Rev. 0

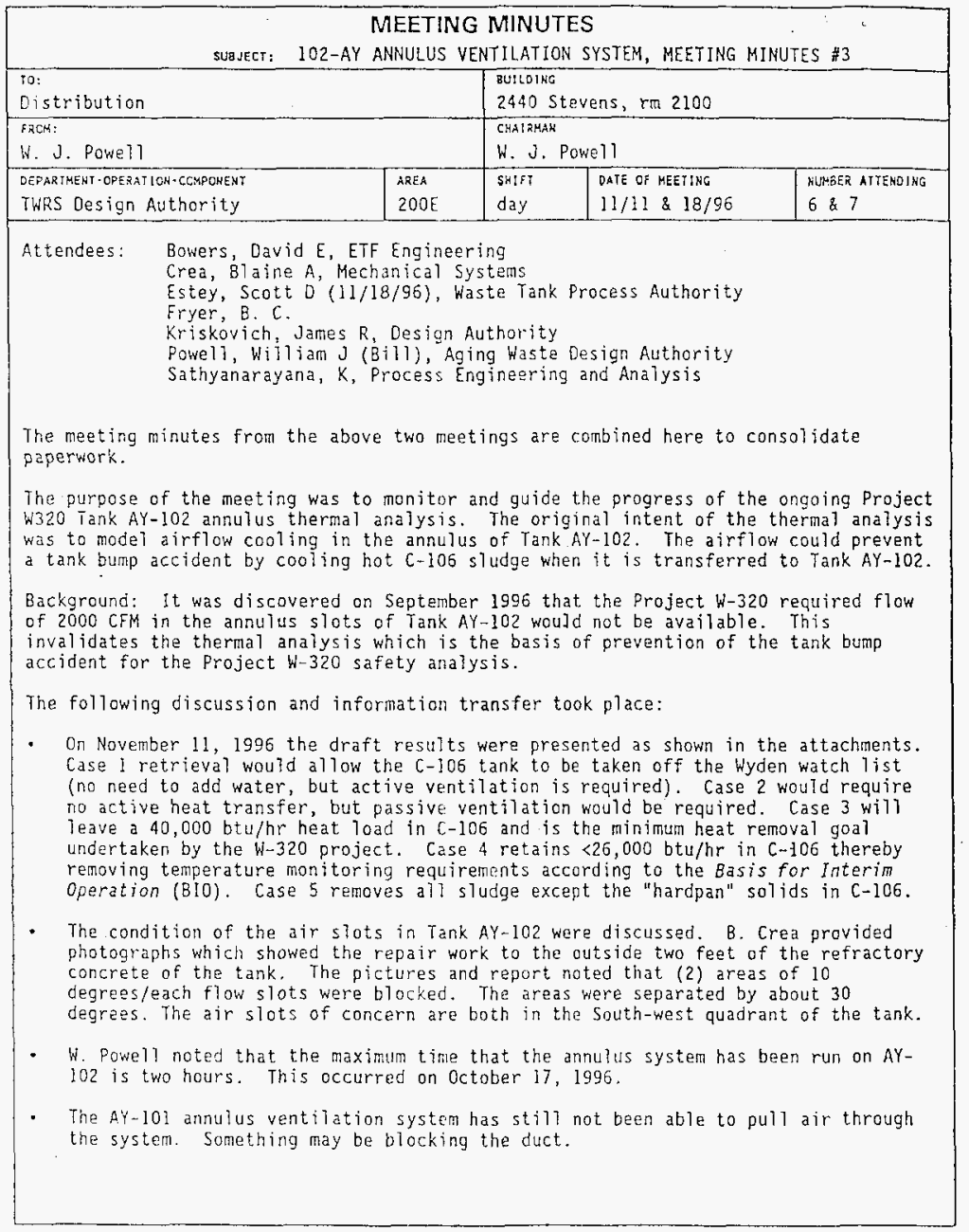

A-3000-680 (10/84) GEFO11 
- Several new scenarios were added to the table in Attachment 1. These items included:

- Varying thermal conductivity of the siudge

- Chijling the supernate in the tank to $40^{\circ} \mathrm{F}$. This requires about 2000 square feet of heat transfer area and (10) 42 -inch diameter helix coils operating at $36^{\circ} \mathrm{F}, 16 \mathrm{gpm}$ and $60 \mathrm{ps} i$ pressure drop. It is not cost effective to introduce these to the existirg tank. No further action is planned on this subject.

- Sathya reported that using only primary heat transfer it was difficult to drive down the supernate temperature. No follow up is planned.

The assumptions in the attached calculations are the same as noted in the November 4, 1996 meeting minutes ( $\left.\frac{\pi}{\pi} 2\right)$ with the following exceptions:

- Tank AY-102 3-inch lines in the inlet piping to the slots were assumed to be removed, when it indicates that the 7 ines are "blocked".

\section{ACTION ITEMS}

Action items 2, 3, 5 and 7 are complete and have been removed from the meeting minutes.

1. D. Ogden group to continue thermal/flow analysis for all cases in Table 1 , excluding: case 4 unblocked (too much total flow), and case 6 (no benefit). Solids fluff factor cases of 1,2 and 3 to be graphed. Partly complete see attachments, need analysis of additional fluff factors, anticipated all or part by November 11 , 1996.

4. K. Carpenter to determine if the air velocities in the 3 -inch piping and concrete slots are acceptable for the high flow cases. Partly complete on Novemier 11, 1996. L. Julyk reports that he has low confidence that air velocities above $2000 \mathrm{cfm}$ through the 4-inch piping suspended in the side of the annulus, and buried in the bottom concrete of the annulus, would avoid vibration damage. These air flows are off the charts of recomended design flow rates for the 4-inch piping. More involved analysis was recomended. A cost estimate for further analysis is proceeding.

On November 11, 1996 B. Crea reported that the flow velocities and resulting vibration in the 4-inch piping encased in concrete are not expected to be a concern. General agreement was expressed and written confirmation was requested.

6. W. Powell to look at contamination cross-connections to determine if the annulus could effectively be segregated from the primary tank, after $\mathrm{H}-030$ installs the new ventilation system and disconnects the existing 702-A ventilation system, which has major cross-connection potential. The potentiai cross-connections found were at the annulus pump pit and the 8-inch line from the annulus to the primary system. The first one is the annulus pump pit $A Y-02 F$, which has leaked before but can be (and may have been) sealed. After review of the IEFDs the AX-152 diversion box had been noted as a potential concern. It was found that the AY-102 IEFDs were in error. There is no anmulus to primary ventilation system cross-connection at $A X-$ 152 diversion box. This makes the scenario of the annulus vacuum being operated at a lower vacuur than the primary tank much more practical. Complete, remove from future meeting minutes.

A. $3000-480(10 / 96)$ GEF011 
HNF-SD-W320-ER-002, Rev. 0

MEETING MINUTES (Continued)

page 3 of 3

8. D. Ogden group to run an additional case of inlet chilled air to primary system, at $500 \mathrm{cfin}$ and $40^{\circ} \mathrm{F}$, due November 11, 1996. Complete, see attachment, remove from meeting minutes.

9. S. Estey to determine what amourit of Cs 137 would solubilize into the supernate, thereby reducing the heat load in the solids. Complete, November 25, 1996 it was found that the CS137 composition was much silaller than the 45,000 btu/hr originally estimated. The Tank Characterization Report for $c-106$ gives $<10,000$ btu/hr as the potential Csi37 heat load. This is about $8 \%$ of the total heat load in C-106. The detailed information has been provided to Sathya. for incorporation into the thermal analysis if it proves significant.

New Action Items:

- 8. Crea volunteered to determine if the temperatures on the bottom of the AY-102 tank decreased when the AY -102 ventilation system was operating on October 17 , 1996. Complete November 26, 1996, the system shown no significant increase in temperature that week compared to the two weeks around it. A $5^{\circ}$ to $5^{\circ} \mathrm{F}$ temperature increase is noted in the SW quadrant of the tank, compared to other quadrants.

Attachments 4

A. $3000 \cdot 480(10 / 94)$ CEFOTI 
HNF-SD-W320-ER-002, Rev. 0

\begin{tabular}{|c|c|c|c|c|c|c|c|c|}
\hline \multicolumn{3}{|c|}{ C-106 Retrievaloptions } & \multicolumn{6}{|c|}{ 1. 1 AY 102 Ventilation Configuration Options } \\
\hline $\begin{array}{l}\text { Case } \\
=\end{array}$ & $\begin{array}{l}\text { Retreval Case } \\
\text { Descriotion } \\
\text { (eeptruhest load) }\end{array}$ & $\begin{array}{r}\text { Comment } \\
\text { con } \\
\end{array}$ & $\begin{array}{c}\text { Chilled Air } \\
40^{\circ} r \\
\end{array}$ & $\begin{array}{l}\text { Winimun } \\
\text { Slct Fions } \\
\text { (cinj) }\end{array}$ & $\begin{array}{c}\text { Lnnulus } \\
\text { Waif Fich } \\
\text { configuraticn } \\
\end{array}$ & $\begin{array}{l}\text { jotal: } \\
\text { Secerdary } \\
\text { System Fion } \\
\text { (ctin) }\end{array}$ & $\begin{array}{c}\text { arnurus } \\
\text { Guase } \\
\text { Presure } \\
(\text { inch tizO) }\end{array}$ & 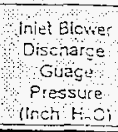 \\
\hline$i$ & $\begin{array}{c}2 \mathrm{ft} \\
13,200 \text { Bturhr }\end{array}$ & $\begin{array}{l}\text { Eiminates } \\
\text { water } \\
\text { additions }\end{array}$ & none & 0 cintis & unclocked & $0 \mathrm{cimi}$ & -0.5 & norie \\
\hline & $2.5 \prime(28,000)$ & & & $1 \leq 5$ & \multirow[b]{2}{*}{ Uñocxed } & \multirow{2}{*}{$4800 \mathrm{cin}$} & -0.5 & 17 \\
\hline \multirow{8}{*}{2} & \multirow{8}{*}{$\begin{array}{c}4: t \\
72,800 \text { Btu/hr }\end{array}$} & \multirow{8}{*}{$\begin{array}{l}\text { Eiminates } \\
\text { ective } \\
\text { vendation }\end{array}$} & \multirow{3}{*}{ none } & \multirow{3}{*}{1000 cin } & & & -12 & 5.5 \\
\hline & & & & & \multirow{2}{*}{ blocked } & \multirow{2}{*}{$1000 \mathrm{cim}$} & -0.5 & 6.0 \\
\hline & & & & & & & -5.5 & none \\
\hline & & & \multirow{4}{*}{ Secondary } & \multirow{4}{*}{$750 \mathrm{cmin}$} & \multirow{2}{*}{ unolocked } & \multirow{2}{*}{$3600 \mathrm{cin}$} & .0 .5 & 9.5 \\
\hline & & & & & & & -10 & none \\
\hline & & & & & \multirow{2}{*}{ blocked } & \multirow{2}{*}{$7 \equiv 0 \mathrm{cin}$} & -0.5 & 3.3 \\
\hline & & & & & & & -3.8 & none \\
\hline & & & Primary & $350 \mathrm{cmin}$ & unclocked & $4100 \mathrm{cim}$ & -12 & none \\
\hline \multirow{5}{*}{3} & \multirow{5}{*}{$\begin{array}{c}4.8 \mathrm{it} \\
92,000 \mathrm{Btu} / \mathrm{hr}\end{array}$} & \multirow{5}{*}{$\begin{array}{l}\text { Eliminates } \\
\text { hign heat } \\
\text { designation }\end{array}$} & \multirow{2}{*}{ none } & \multirow{2}{*}{$2000 \mathrm{~cm}$} & \multirow{2}{*}{ blocked } & \multirow{2}{*}{$2000 \mathrm{cfm}$} & .0 .5 & 25 \\
\hline & & & & & & & -12 & -3 \\
\hline & & & \multirow{2}{*}{ Secondary } & \multirow{2}{*}{$1400 \mathrm{cin}$} & \multirow{2}{*}{ blocked } & \multirow{2}{*}{$1400 \mathrm{~cm}$} & -0.5 & 13 \\
\hline & & & & & & & -12 & 1.0 \\
\hline & & & $\begin{array}{l}\text { Primary \& } \\
\text { Secondary }\end{array}$ & $1200 \mathrm{ctm}$ & blocked & $1200 \mathrm{~cm}$ & -9.5 & none \\
\hline \multirow{4}{*}{4} & \multirow{4}{*}{$\begin{array}{c}5.2 \mathrm{t} \\
106,000 \text { 8tuhr }\end{array}$} & \multirow{4}{*}{$\begin{array}{l}\text { Eliminates } \\
\text { temperature } \\
\text { monitoring }\end{array}$} & \multirow{2}{*}{ none } & \multirow{2}{*}{$3000 \mathrm{cim}$} & & & -0.5 & 58 \\
\hline & & & & & blocked & $3000 \mathrm{~cm}$ & -12 & 47 \\
\hline & & & & & & & -0.5 & 31 \\
\hline & & & Secondary & $2200 \mathrm{cim}$ & blocked & $200 \mathrm{~cm}$ & -12 & 19 \\
\hline$=?$ & & & & & & & -0.5 & 40 \\
\hline$\checkmark$ & 132,000 Btu/hr & retrieval & secondary & $2600 \mathrm{cmin}$ & rlocked & $\angle 500 \mathrm{Ci}$ & -12 & 29 \\
\hline
\end{tabular}

i. Case 5 assumes a fuffing factor of 1.5 . 
HNF-SD-W320-ER-002, Rev. 0

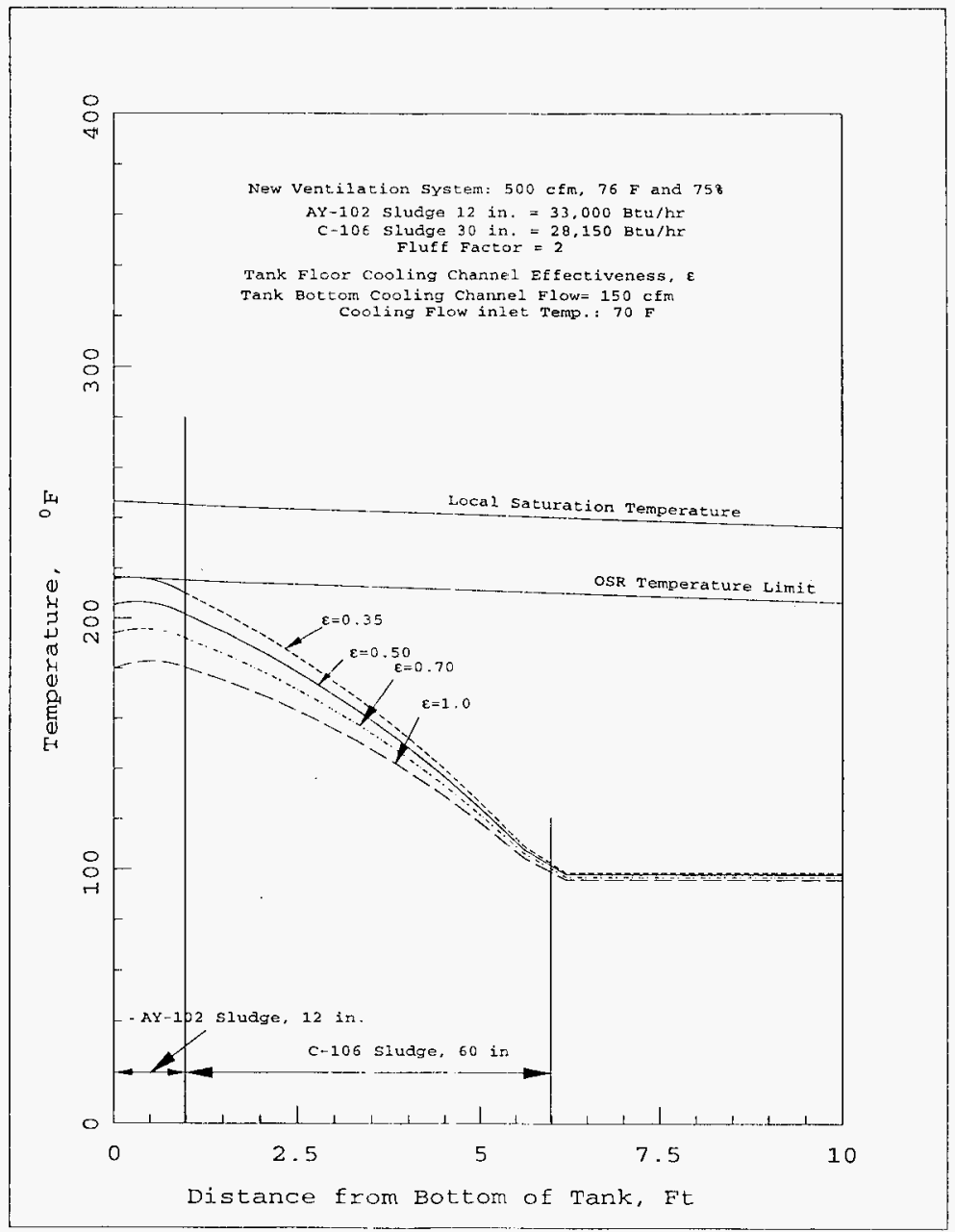

Figure 7.63 Temperature Distribution for the combined Sludge of $\mathrm{AY}-102$ and $\mathrm{C}-106$ using $150 \mathrm{cfm}$ Floor Cooling slot flow and its effectiveness as a parameter. 
HNF-SD-W320-ER-002, Rev. 0

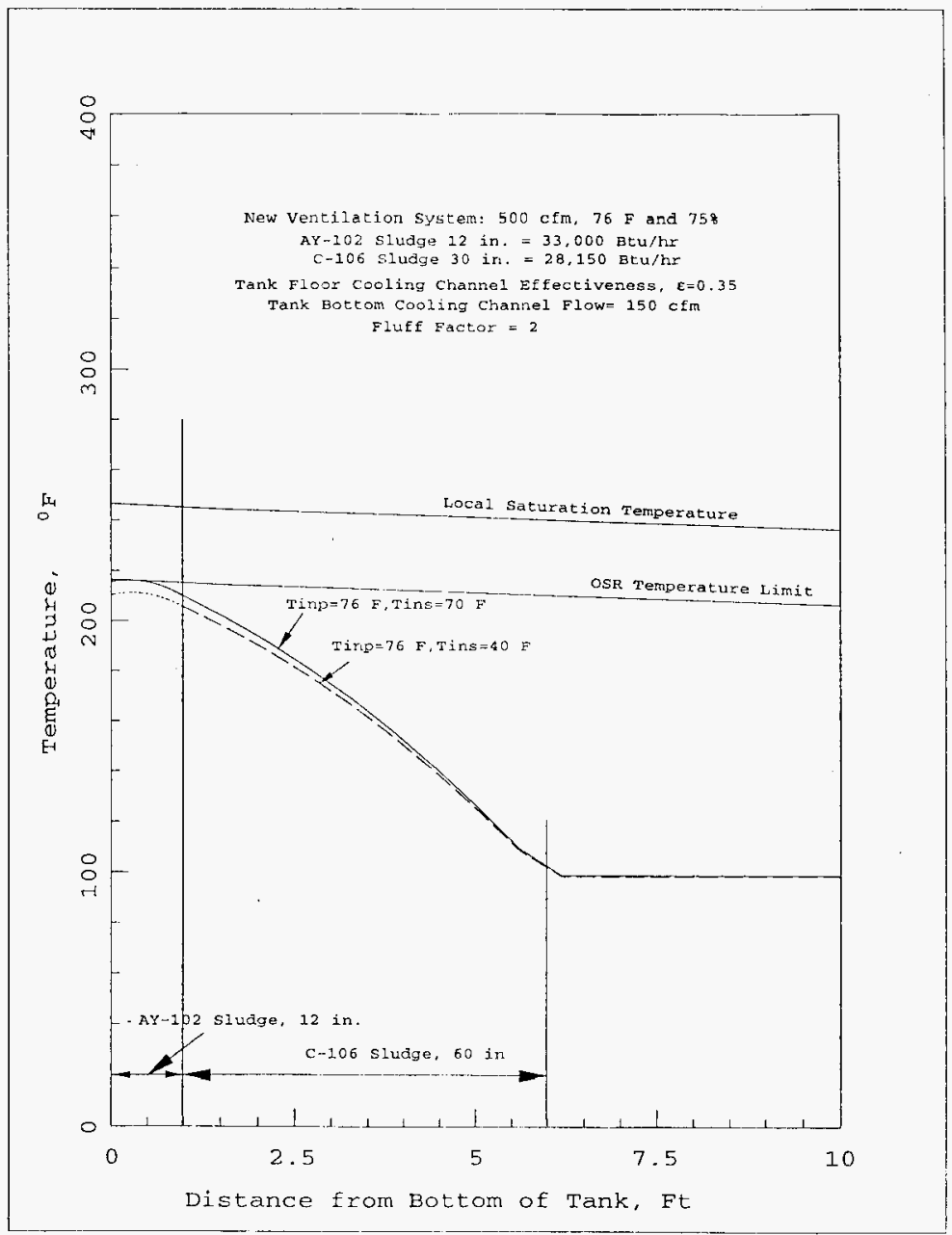

Figure 7.61 Temperature Distribution for the combined Sludge of AY-102 and C-106 using Chilled and Unchilled Floor cooling slot Flow. 


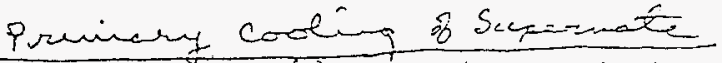

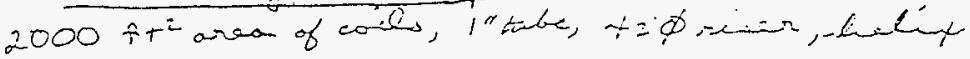

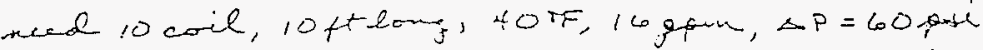

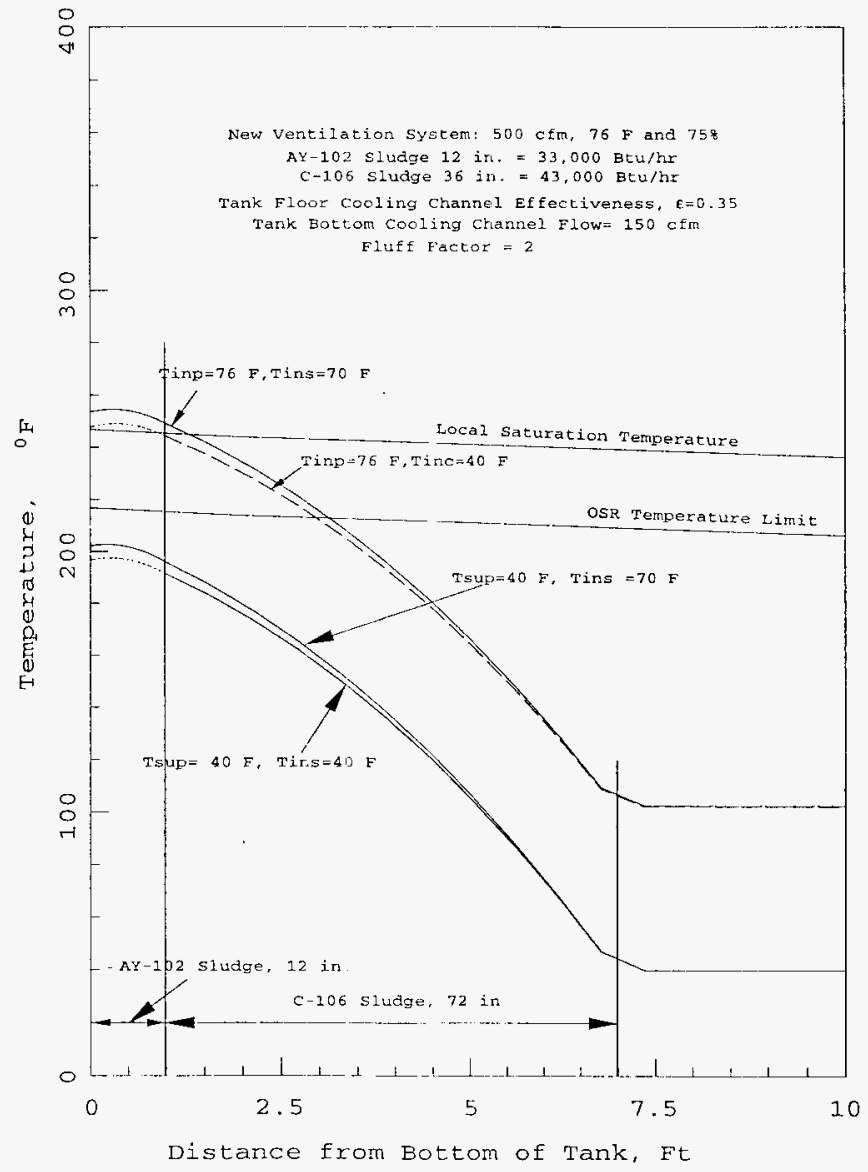

Figure 7.57 Temperature Distribution for the combined Sludge of AY-102 and C-106 using Chilled and Unchilled Floor Cooling slot Flow and cooled supernate. 
HNF-SD-W320-ER-002, Rev. 0

(This page intentionally left blank.) 
HNF-SD-W320-ER-002, Rev. 0

\section{APPENDIX - I}

JMI-WT002 Report

Revised Tank Heat Load Estimate For Tank C-106

Based on GOTH Analysis of The Process Test

B. C. Fryer

M. J. Thurgood

John Marvin, Inc. 


\section{HNF-SD-W320-ER-002, Rev. 0}

(This page intentionally left blank.) 


\title{
REVISED TANK HEAT LOAD ESTIMATE \\ FOR TANK C-106
}

\section{BASED ON GOTH ANALYSIS OF THE PROCESS TEST}

\author{
By \\ JOHN MARVIN, INC. \\ B. C. Fryer
}

M.J. Thurgood

For

WESTINGHOUSE HANEORD COMPANY

November 9, 1995 


\section{SUMMARY}

Several thermal hydraulic analyses of Tank C-106 have been conducted. The tank heat load is one of the fundamental parameters used as a basis for each of these analyses. Comparisons of calculations to thermal hydraulic data is one of the means utilized to estimate tank heat loads and this method has been used for Tank C-106.

This report documents the results of a recent revised GoTH thermal hydraulic simulation associated with the 1994 process test which resulted in an estimated tank heat load of 132,400 btu/hr for the 1994 time period, which is higher than previous estimates. For analyses related to safety considerations where realistic to conservative tank heat load estimates are desired, this value is recommended.

\section{INTRODUCTION}

Several thermal hydraulic analyses of Tank C-106 have been conducted to characterize and to help understand the thermal hydraulic behavior of this tank [Ref. 1, Ref. 2., Ref. 3, Ref. 4, Ref. 5, Ref. 6, Ref. 7, Ref. 8., Ref. 9, Ref. 10, and Ref. 11]. From mid 1994 to mid 1995, the analysis efforts have focused on the 1994 process test and the dynamic response of thermocouples located in the sludge on the tree located in riser 14. Recentiy thermal

hydraulic analysis associated with transferring most or all of the sludge from Tank C-106 to the ageing waste Tank Farm AY/AZ has been initiated. The tank heat load is one of the fundamental parameters used as a basis for each of these analyses. Comparisons of calculations to thermal hydraulic data is one of the means utilized to estimate tank heat loads and this method has been used for Tank C-106. The calculation methods and associated assumptions have varied, and the estimated tank heat loads have also varied.

This report documents the results of a recent revised GOTH thermal simulation associated with the 1994 process test 
which resulted in an estimated tank heat load of 132,400 btu/hr for the 1994 time period. This is higher than that of the most recent prior estimate of $110,000 \mathrm{btu} / \mathrm{hr}$ for January 1992 tank operation and 102,000 btu/hr for January 1995 operation (i.e. decreaseing at a rate of $2.5 \% /$ year) [Ref. 3]. Although a heat load of $132,400 \mathrm{btu} / \mathrm{hr}$ for the 1994 time period may be on the high side due to assumptions made for soil conductivity, etc., a tank heat load this high was required for the revised GOTH simulation to match the tank level data during the 1994 process test. For analyses related to safety considerations where realistic to conservative tank heat load estimates are desired, this value is recommended for Tank $\mathrm{C}-106$.

\section{REVISED GOTH SIMULATION OF THE PROCESS TEST}

\subsection{GOTH 2-D MODEL}

The GOTH 2-D model utilized to conduct this thermal hydraulic analysis includes the tank, tank sludge, liquid and gas contents, the inlet and outlet ventilation gas flows, and the soil beneath, to the side, and above the tank. January-December 1994 hourly meteorological conditions consisting of barometric pressure, dry bulb temperature, and relative humidity were used as dome ventilation inlet conditions. Although the simulation discussed here included a small portion of the 1995 calendar year, for that portion, the corresponding portion of the 1994 meteorology was repeated. Soil surface conditions are assumed to be at ambient air temperature. Ground water is assumed to be at $55^{\circ} \mathrm{F}$.

The nodalization used in the tank and soil are provided in Figures 3.1 and 3.2 . 


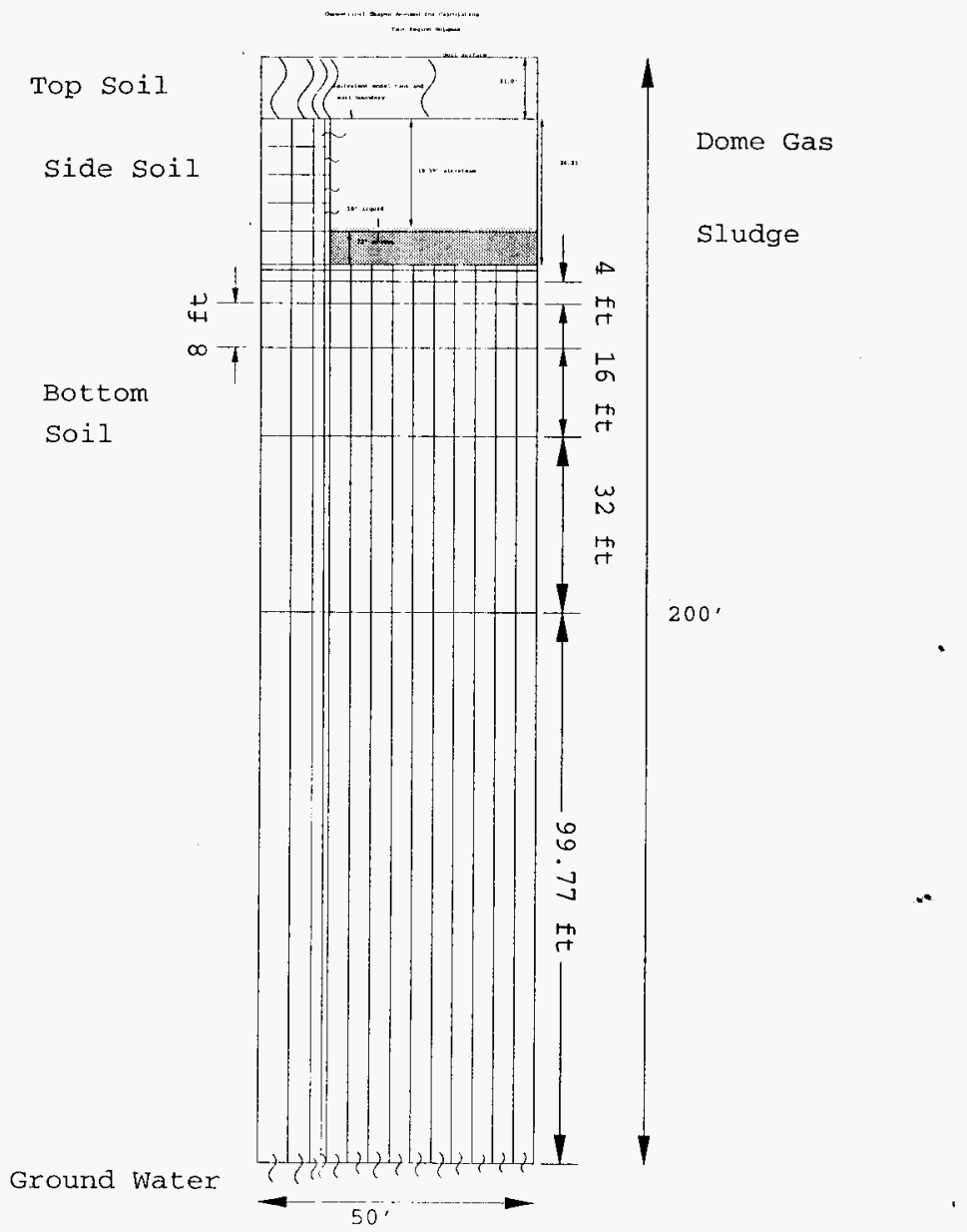

Figure 3.1 2-D Tank C-106 plus Soil Nodalization and Heat Conductors 


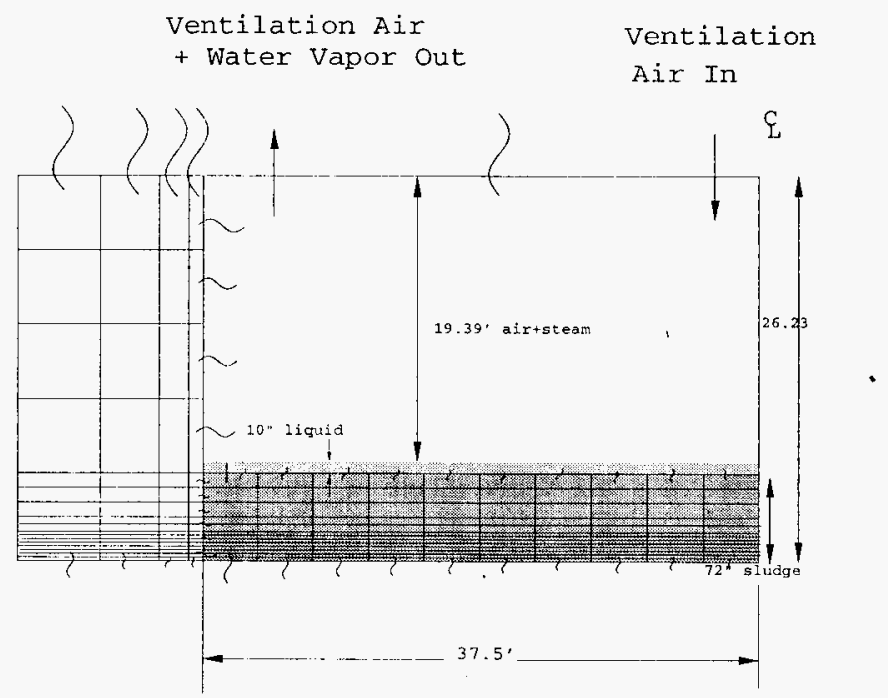

Figure 3.2 2-D Tark C-106 and tank side soil nodalization plus heat conductor details 
The model's nodalization, ventilation, sludge depth, and geometry remain the same as previously reported [Ref. 7]. However, changes were made in the tank heat load to better match the tank level decrease during the process test. Also axial conductance of the tank concrete and steel wall adjacent to the sludge was added to the model, and changes in the conductivity and axial distribution of conductivity in the sludge, and the soil conductivity were made to obtain a better comparison to the riser 8 sludge thermocouples. The power distribution remains the same as the previous referenced analysis. In the previous analysis a uniform sludge conductivity of .59 btu/hr-ft-F was assumed. In the revised simulation, reported here, the conductivity was varied, increasing from the bottom to the top of the sludge. The power and sludge conductivity distribution assumed is provided in Table 3.1 below.

Table 3.1 Sludge Power and Thermal Conductivity Distribution Versus Distance Interval From The Bottom of . The Tank

\begin{tabular}{|c|cc|}
\hline $\begin{array}{c}\text { Distance from tank } \\
\text { bottom--ft }\end{array}$ & $\begin{array}{c}\text { Fraction of Total } \\
\text { Total Power }\end{array}$ & $\begin{array}{c}\text { Sludge } \\
\text { Conducitiv }\end{array}$ \\
\hline & & $\frac{\text { btu }}{\text { hr-ft-F }}$ \\
\hline $0-3$ & 0.78 & 0.5000 \\
$3-4$ & 0.10 & 0.7500 \\
$4-6$ & 0.12 & 1.0000 \\
\hline
\end{tabular}

The soil conductivity was increased from $.15 \mathrm{btu} / \mathrm{hr}-\mathrm{ft}-\mathrm{F}$ in the previous analysis to $.43 \mathrm{btu} / \mathrm{hr}-\mathrm{ft}-\mathrm{F}$. The revised value is on the high side for drier Hanford soils, but somewhat low for high moisture content soils. 


\subsection{Revised GOTH Model Simulation Results}

The primary purpose of this analysis was to develop an estimate of the tank heat load required to correctly simulate the tank level decrease during the 1994 process test, but prior to crust uncovery. Prior GOTH simulations based on a tank heat load of $110,000 \mathrm{btu} / \mathrm{hr}$ tended to under predict the rate of level decrease during the process test as shown in Figure 3.3 taken from [Ref. 7]. In addition these prior simulations also overestimated the sludge temperature near the wall based on riser 8 thermocouple data.

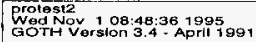

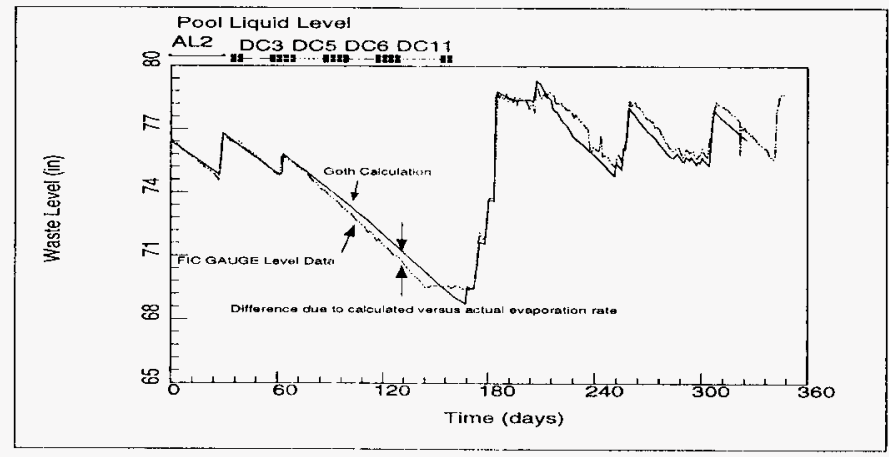

Figure 3.3 Comparison of calculated waste level and FIC level gauge measurements--Prior Model simulation

During the period of the process test prior to crust uncovery, it appears, based on prior GOTH analysis and the near linear characteristic of the level data, that during this time period, no voids were present. If additional steam was being produced during this time period then the 
rate of decrease would likely not be linear. During this time interval the tank contents are generally increasing in temperature, therefore, it is unlikely that steam, if it were present, would be decreasing in volume due to condensation. It then follows that the rate of level decrease during this time period is likely due entirely to evaporation, with none due to increases or decreases in steam volume during this time interval.

To increase the rate of evaporation during this time interval the tank heat load was increased above 110000 btu/hr, and iteratively adjusted until the calculated rate of level decrease matched the observed level decrease rate. Using this iterative process, it was determined that a tank heat load of $132,400 \mathrm{btu} / \mathrm{hr}$ was required to match the level data during the process test. A comparison of the observed tank level to that calculated with the revised model during 1994, and for a short period into 1995, is provided in Figure 3.4. Prior to crust uncovery • during the process test there is only a very small difference between the actual and calculated levels versus time, and therefore only a small difference between the actual and calculated evaporation rates during this interval. Following the process test the actual and calculated levels also agree quite well indicating that the combination of calculated evaporation rates, plus level swell or contraction due to voidage, are consistent between the revised simulation and the actual tank behavior. 


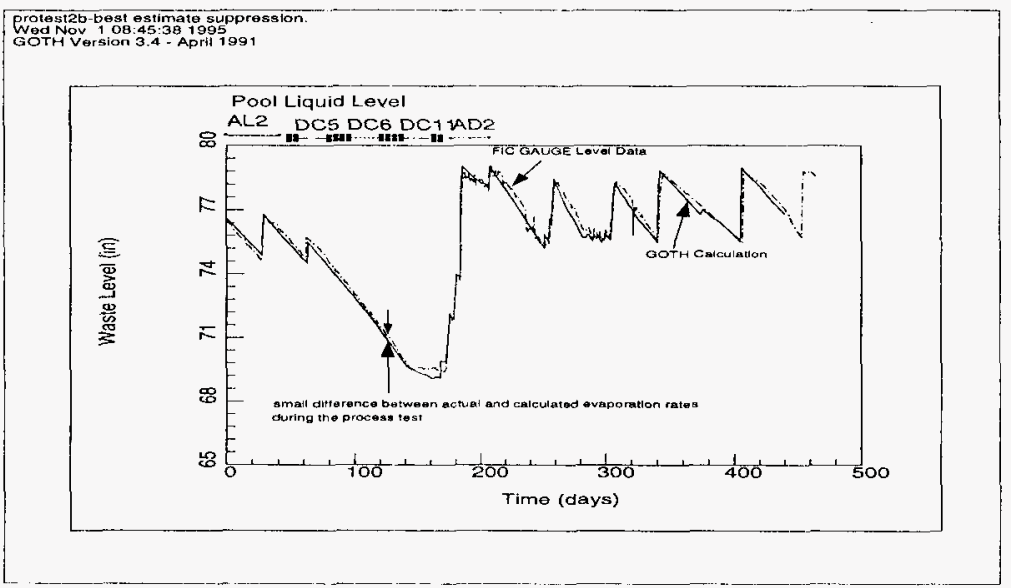

Figure 3.4 Comparison of calculated waste level and FIC level gauge measurements--Revised Model simulation

As noted above, adjustments were also made to the assumed soil and sludge conductivity, and, axial conduction due to the concrete/steel wall was added to the model to obtain a better comparison to the riser 8 sludge thermocouple data. Although the calculated temperatures in the sludge near the wall decreased relative to previous calculations, the revised calculated sludge temperatures near the wall were still higher than the data from riser 8 thermocouples. Further reductions in calculated sludge temperatures near the wall were achieved by further increases in soil conductivity beyond that described in this report, however, to achieve a match with the data, soil conductivity values had to be increased to unreasonably high values. Recent data suggests that riser 8 may have convective effects near the thermocouple tree similar to riser 14, but significantly reduced in magnitude. This may account for the difference between calculated sludge temperatures near the wa1l and temperatures measured in the sludge. 
The impact of these modeling revisions on other important simulation parameters can be observed by comparing the following Figures 3.5-3.13 with the corresponding figures from the previous model in [Ref. 7, Section 5.2.4].

Figures 3.5-.7 illustrate that dome gas, and liquid pool, temperatures are slightly higher for the revised simulation versus the referenced prior simulation before crust uncovery. After crust uncovery the difference increases further, however, following several water additions the difference again decreases. The differences in upper sludge temperature between the revised and prior simulations is smaller than that observed for the dome gas and pool. The differences are consistent with the changes made in the revised model for tank power, sludge and soil conductivity, and evaporation suppression relative to the prior model.

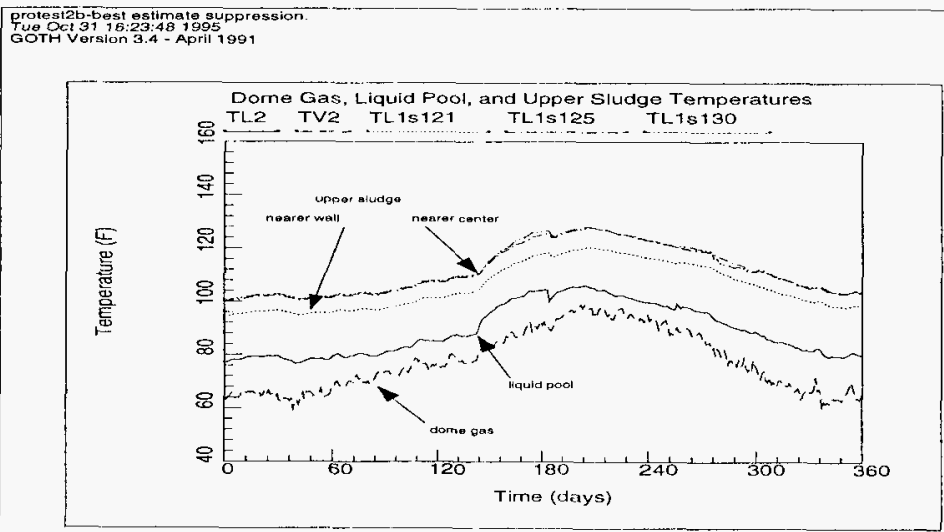

Figure 3.5 Calculated dome gas, liquid pool, and upper sludge temperature simulation under process test conditions 
Figure 3.6 compares calculated dome temperature to actual dome temperature. Following crust uncovery the calculated dome temperature exceeds the measured dome temperature. Also graphed is the calculated saturation steam temperature corresponding to the calculated partial pressure of steam in the dome. These results suggest the evaporation suppression assumed may be too large, since evaporation suppression elevates pool temperature, which in turn elevates the dome temperature, since convective heat transfer from the pool to the dome gas is not assumed to be suppressed.

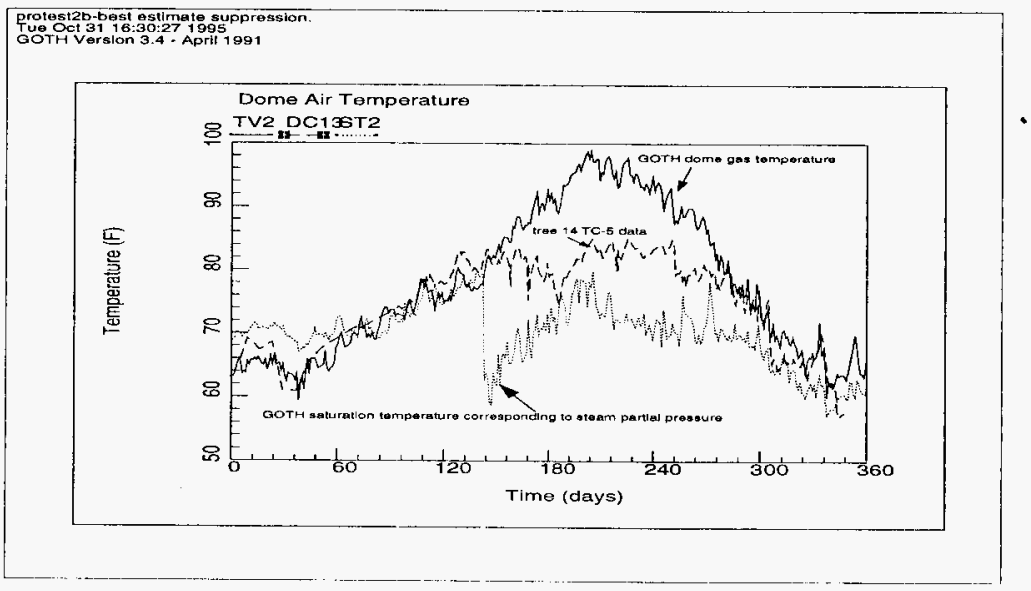

Figure 3.6 Comparison of calculated dome gas temperature and thermocouple tree $14 \mathrm{TC}-5$ dome gas measurements

Figure 3.7 compares the calculated pool temperature to both riser $8 \mathrm{TC}-4$ and riser $14 \mathrm{TC}-4$. As indicated there, following crust uncovery the calculated pool temperature 
exceeds the temperature measured at either of these thermocouples. This suggests that the amount of suppression utilized in the simulation may be too large.

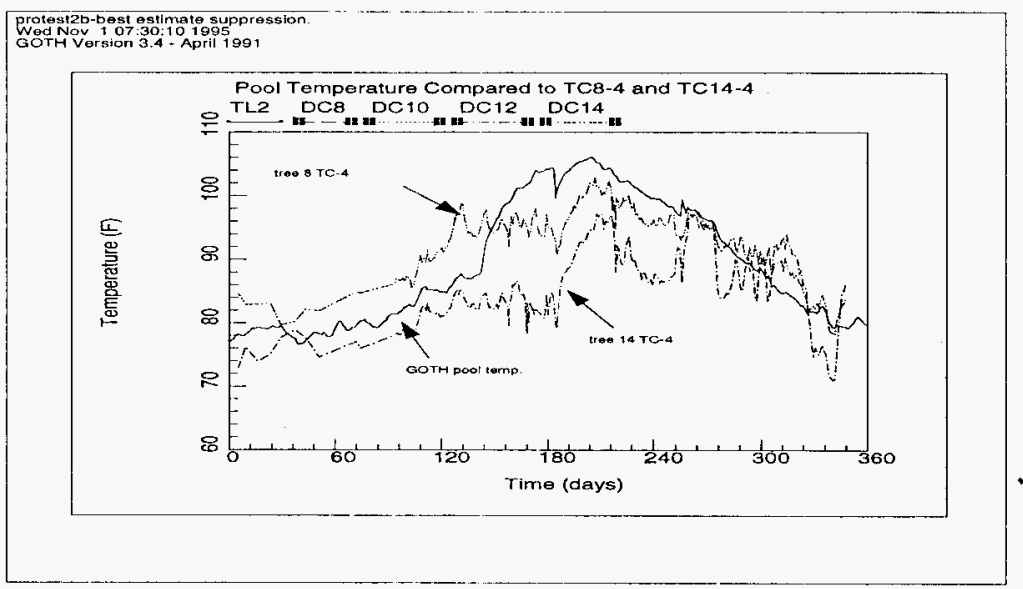

Figure 3.7 Comparison of calculated 1iquid pool temperature and thermocouple trees 8 \& 14 TC-4 liquid pool measurements

The evaporation rate for the revised model is somewhat higher than the prior model before crust uncovery during the process test. Following crust uncovery, greatex evaporation suppression was required in the revised model than the prior model to produce the correct level versus time. The level as noted previously is a result of the combined effect of integrated water additions, evaporation, . and steam generation or condensation in the siudge. 


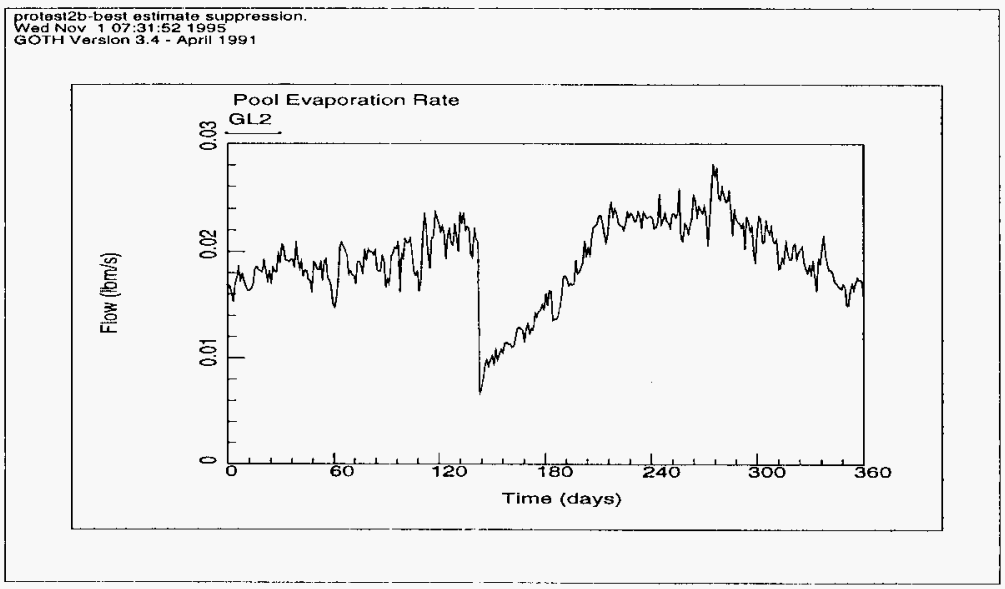

Figure 3.8 Simulation of pool evaporation rate under process test conditions

During the process test voids are calculated to be generated initially in the lower central region of the tank sludge. This saturation zone or void bearing sludge region spreads radially towards the wall. Although the void region does begin to move vertically upwards, a combination of factors limit its advance. Reduced heat generation in a vertical region due to radial displacement of heat generating sludge as a result of voidage, and a reduced conduction distance between the saturation zone and the liquid pool causes the upper fringes of this region to cool and thereby stops the vertical advancement of the saturation zone. Since the sludge is cooler near the wall the radial advancement of the void region is also limited. The initiation, growth, and condensation of this zone during and following the process test is illustrated with the following 5 time snapshots of the void distribution within the sludge, Figures 3.9-3.14. Note that the vertical scale of the 
sludge cross section is distorted as in previously documented void fraction contour plots. Steam formation was calculated to begin occurring at about the time crust uncovery started during the process test. Also, all of the steam voids had disappeared in the simulation by the end of December, 1994.

Although the sludge envelope containing steam in this revised simulation appears to be somewhat smaller than in the prior simulation, the volume fraction of steam within the envelope appears somewhat larger. Therefore the volume of steam within the sludge is probably about the same. 
protest2b-best estimate suppression.

Wed Nov 1 07:55:19 1995

GOTH Version 3.4 - April 1991

SLUDGE VOID FRACTION CONTOURS:

SUMMER OF 1994 FOLLOWING PROCESS TEST

(note distorted vertical scale)

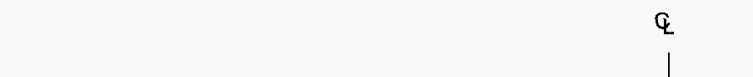

8

Minimum $=0.03$ (rel)

Maximum $=0.45$ (rel)

Time $=1.15051 \mathrm{e}+08 \mathrm{~seconds}$

Channels $=110 /$

GOTH $3.2 \quad 07 / 18 / 25 \quad 13.28: 34$

$50.00 \mathrm{ft}$

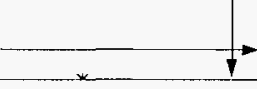

Figure 3.9 Calculated Void Distribution in Sludge at 174.2 days from January 1, 1994. 


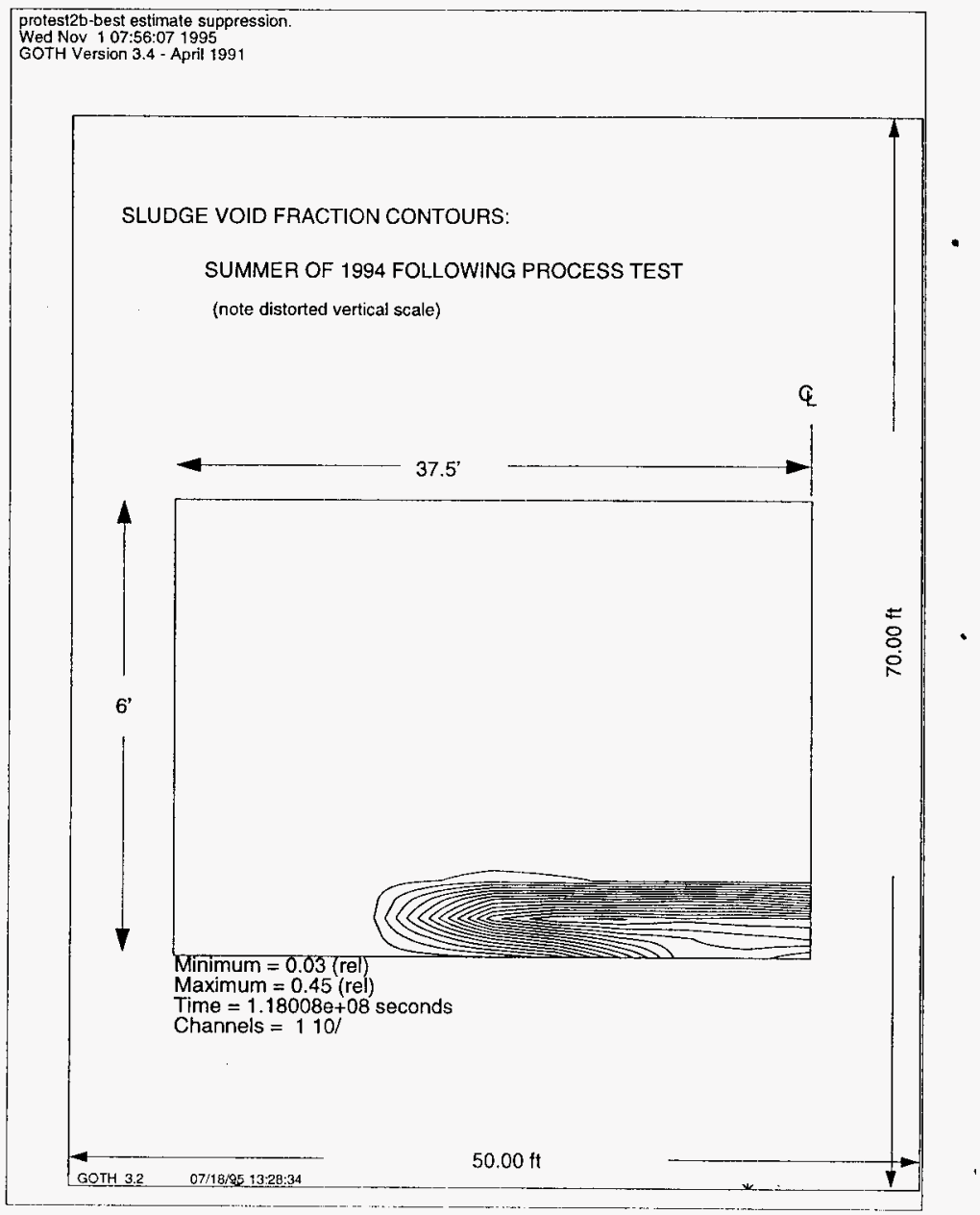

Figure 3.10 Calculated Void distribution in sludge at 208.4 days from January 1, 1994. 


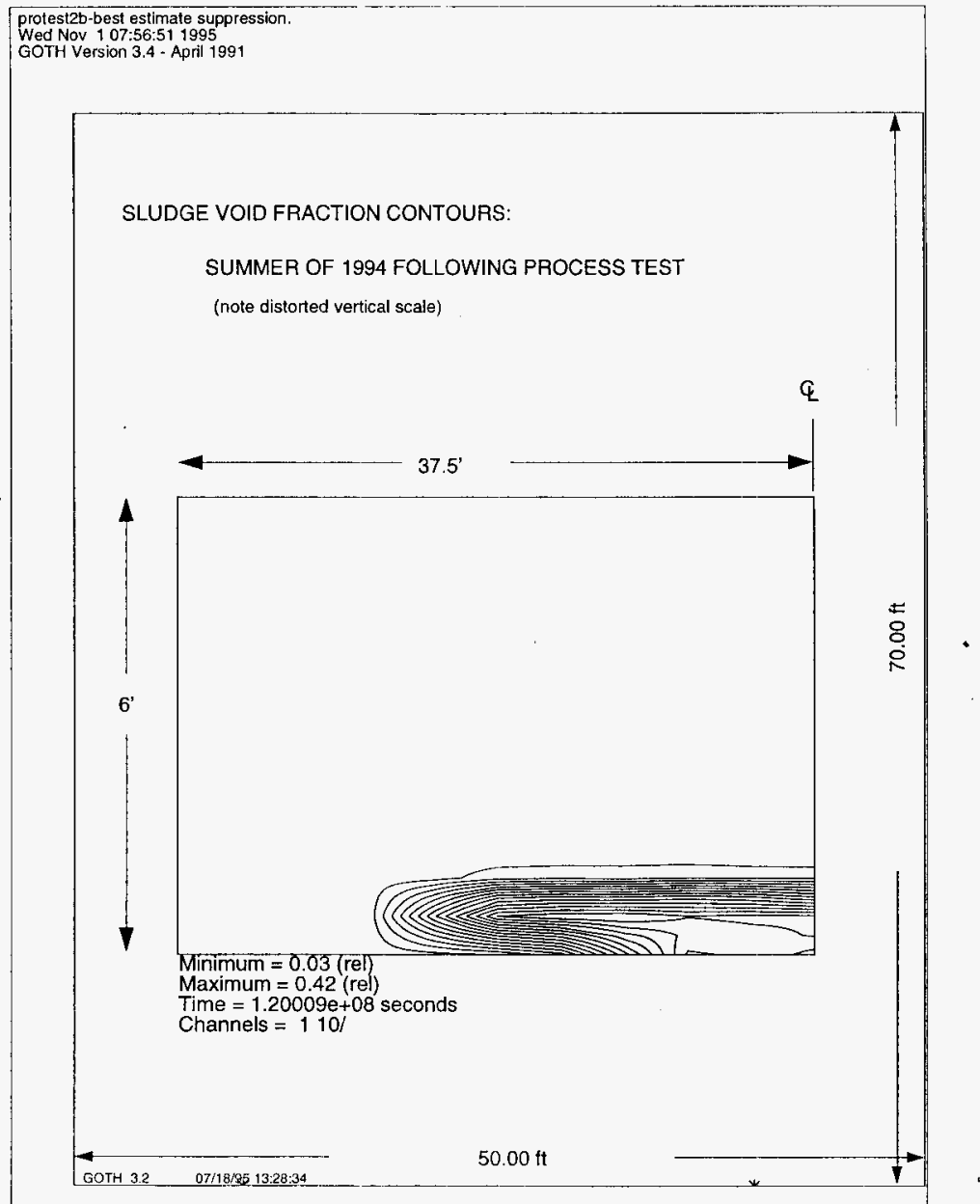

Figure 3.11 Calculated Void distribution in sludge at 231.6 days from January 1, 1994. 


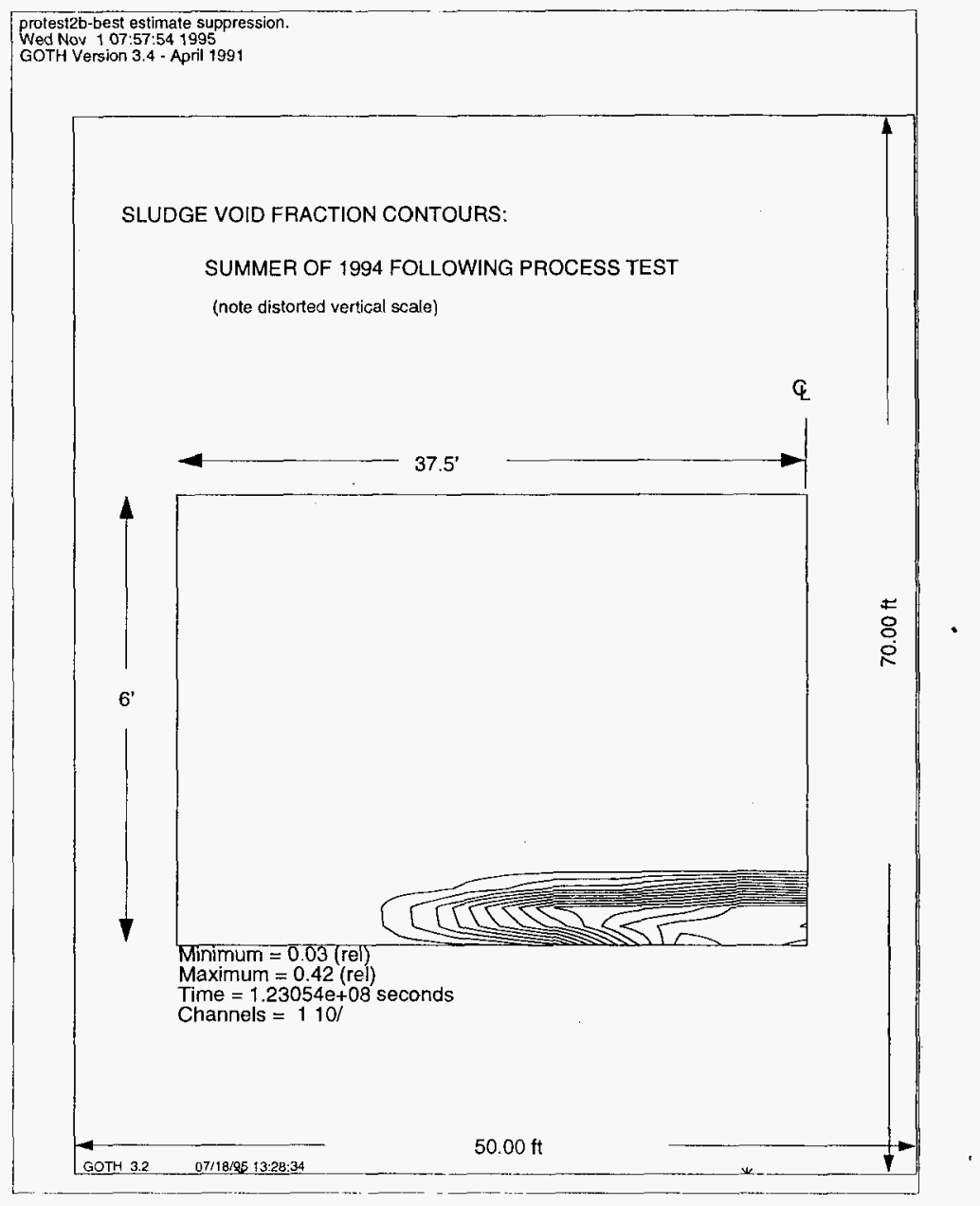

Figure 3.12 Calculated void distribution in sludge at 266.8 days from January 1, 1994. 


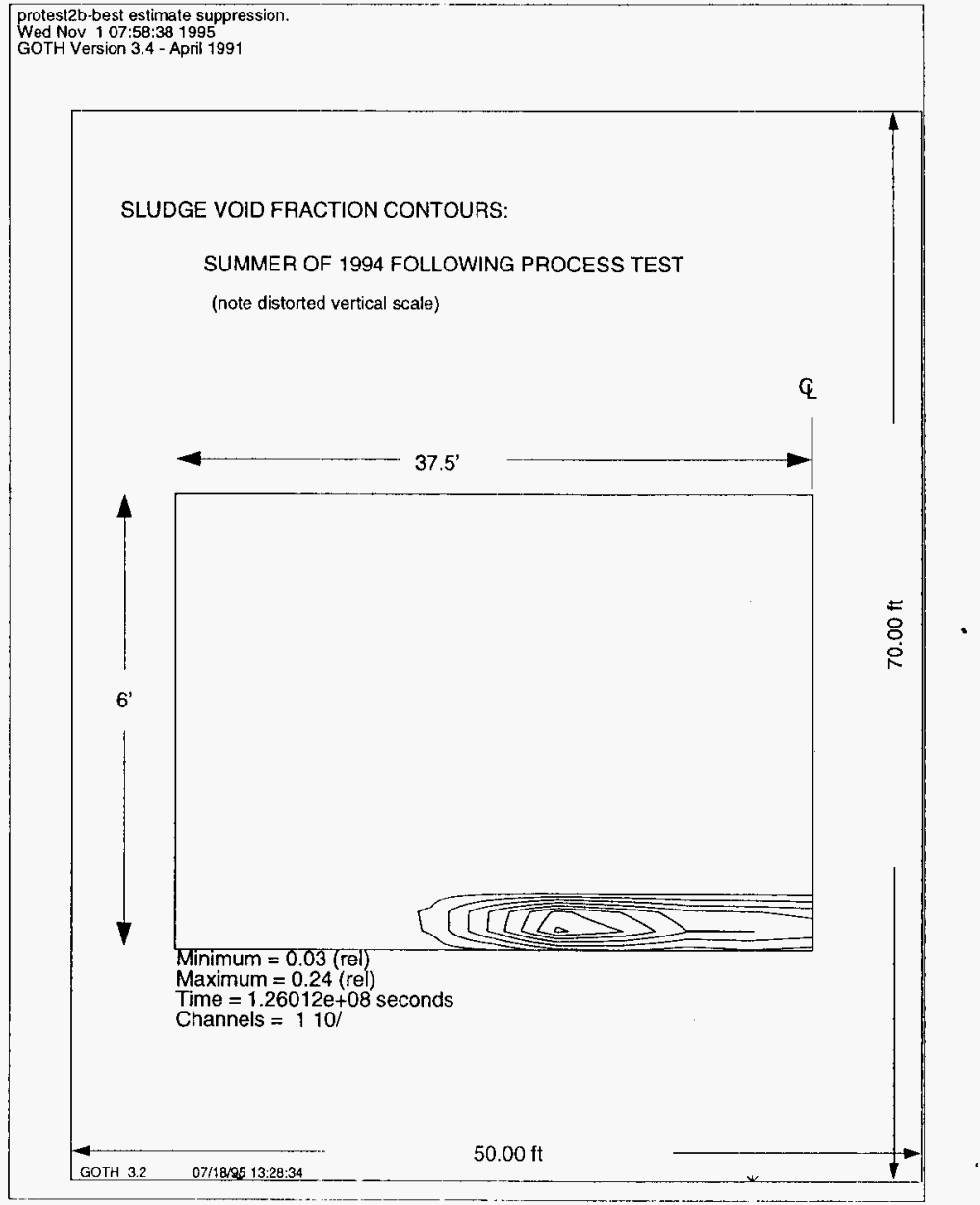

Figure 3.13 Calculated Void distribution in sludge at 301.1 days from January 1, 1994. 


\section{CONCLUSIONS}

The revised GOTH simulation assuming a tank heat load of $132,400 \mathrm{btu} / \mathrm{hr}$ provides a better comparison to level data than a prior referenced simulation assuming a tank heat load of $110,000 \mathrm{btu} / \mathrm{hr}$, particularly during the process test. However, the amount of evaporation suppression required to achieve this was increased and resulted in less favorable comparisons to tank dome gas and pool temperatures. This suggests that the combination of assumptions used in the revised model may be somewhat conservative and that the tank heat load of $132,400 \mathrm{btu} / \mathrm{hr}$ may be higher than the actual tank heat load. However, for safety purposes it is prudent to error on the conservative side, and therefore this tank heat load is recommended for use in future safety related analyses.

\section{REFERENCES}

Ref. 1. Bander, T.J., August 1992, Thermal History of Tank 241-C-106, WHC-SD-WM-ER-161, Westinghouse Hanford Company, Richland, WA.

Ref. 2. Bander, T.J. and Stevens, P.A., January 1993, Thermal Analysis of Tank 241-C-106 in support of Process Test, WHC-SD-WM-ER-189, Westinghouse Hanford Company, Richland, WA.

Ref. 3. Bander, T.J., Revised Thermal History of Tank 241-C-106, WHC-SD-WM-ER-200, Westinghouse Hanford Company, Richland, WA.

Ref. 4. Bander, T.J., September 1993, Tank 241-C-106:

Radial Variation of Thermal Conductivity and Heat. Generation, WHC-SD-WM-ER-217, Westinghouse Hanford Company, Richland, WA. 
Ref. 5. Bander, T.J., November 1993, Tank 241-C-106 Parametric Studies in Support of Safety Alternative Process, WHC-SD-WM-ER-217, Westinghouse Hanford Company, Richland, WA.

Ref. 6. Thurgood, M.J., et. a1., August 1994, Preliminary Report--Tank C-106 Thermal Hydraulics Analysis Related to the March 10-June 15, 1994 Process Test and Temperature Rise of Riser 14 Thermocouples, NAI-940708-1, Numerical Applications Inc., for Westinghouse Hanford Company, Richland, WA.

Ref. 7. Thurgood, M.J., et. al., March 1995, GOTH Tank C-106 Thermal Hyaraulic Analysis Related to the 1994 Process Test, NAI-940708-3, Numerical Applications Inc. for Westinghouse Hanford Company, Richland, WA.

Ref. 8. Thurgood, et. al., March 1995, GOTH Tank C-106 Thermal Hydraulic Heat Up Analysis Following a Hypothetical . Leak, NAI-940708-4, Numerical Applications Inc. for Westinghouse Hanford Company, Richland, WA.

Ref. 9. Rensink, G.E., May 1995, Contingency Chiller System Design Report for Tank 241-C-106, WHC-SD-WM-ROT-162, Westinghouse Hanford Company, Richland, WA.

Ref. 10. Bander, T.J., May 1995, Tank 241-C-106 Process Test Report, WHC-SD-WM-ER-427, Westinghouse Hanford Company, Richland, WA.

Ref. 11. Bander, T.J., September 1995, Tank 241-C-106 Thermal Hydraulic Analysis to Establish the Cooling Liquid. at a Minimum Level, WHC-SD-WM-ER-495, Westinghouse Hanford Company, Richland, WA. 
TH... WI BLANK

. 


\begin{tabular}{|c|c|c|c|c|c|}
\hline \multicolumn{6}{|c|}{ DISTRIBUTION SHEET } \\
\hline To & \multirow{2}{*}{\multicolumn{3}{|c|}{$\begin{array}{l}\text { From } \\
\text { Process Engineering Analysis }\end{array}$}} & \multicolumn{2}{|l|}{ Page 1 of 2} \\
\hline Distribution & & & & \multicolumn{2}{|c|}{ Date $2 / 27 / 97$} \\
\hline \multirow{2}{*}{$\begin{array}{l}\text { Project Title/Work Order } \\
\text { W-320/D2MTR }\end{array}$} & & & & \multirow{2}{*}{\multicolumn{2}{|c|}{\begin{tabular}{|ll} 
EDT No. & 614693 \\
ECN No. & N/A \\
\end{tabular}}} \\
\hline & & & & & \\
\hline Name & MSIN & $\begin{array}{l}\text { Text } \\
\text { With All } \\
\text { Attach. }\end{array}$ & Text Only & $\begin{array}{l}\text { Attach./ } \\
\text { Appendix } \\
\text { Only }\end{array}$ & $\begin{array}{l}\text { EDT/ECN } \\
\text { Only }\end{array}$ \\
\hline
\end{tabular}

Fluor Daniel Northwest, Inc.

J. C. Conner

S. K. Farnworth

D. L. Evans

J. J. Houston

H. P. Shrivastava

NUMATEC

Jean-Noel Alibert

J. W. Bailey

A. F. Choho

T. A. Flament

B. C. Fryer

J. P. Harris III

W. C. Miller

D. M. Ogden (2)

K. Sathyanarayana (10)

J. P. Sloughter

Central Files (Original + 2)

$\begin{array}{ll}\text { A2-25 } & x \\ \text { H5 }-57 & x \\ \text { S2-47 } & x \\ H 5-61 & x \\ B 4-40 & x\end{array}$

$\mathrm{S} 2-48 \quad \mathrm{x}$

S2- $48 \quad x$

$H 6-35 \quad x$

K9-46 $\quad x$

$\mathrm{HO}-34 \mathrm{X}$

S2-48 $\quad X$

H5-25 X

$\mathrm{HO}-34 \quad X$

$\mathrm{HO}-34 \quad X$

$\mathrm{HO}-34 \quad X$

A3-88 $X$

\section{Lochheed Martin Hanford Corporation}

T. Bohan

R. V. Gutierrez

N. W. Kirch

K. W. Leliefeld

J. W. Lentsch

L. B. McDaniel

W. P. Nelson

W. J. Powe11

S. H. Rifaey

W. T. Thompson

\section{Duke Enqineering Services Hanford}
R. J. Stickney
0 . M. Serrano
C. E. Leach

$\begin{array}{ll}\text { S5-04 } & x \\ S 4-44 & x \\ \text { R2-11 } & x \\ \text { S2-48 } & x \\ \text { S2-48 } & x \\ H 7-06 & x \\ \text { S5-12 } & x \\ \text { S2-48 } & x \\ \text { R1-56 } & x \\ H 5-24 & x\end{array}$

$\begin{array}{ll}R 1-49 & x \\ R 2-38 & x \\ R 1-49 & x\end{array}$ 


\section{I... . IUNALLY LLI I BLANK}


EDT -614693

Page 2 of 2

SGN Eurisys Services Corp.

v. R. Betlomy

$S 2-48$

$x$

Pacific Northwest National Laboratory

C. W. Stewart

K $7-15$

$\mathrm{x}$ 
THIS PF' ' INTENTIONALLY

LEFT BLANK 